\title{
RELEASE AUTHORIZATION
}

Document

Number:

WHC-SD-WM-TI-638, REV. 0

$\begin{array}{ll} & \text { PRELIMINARY FLOWSHEET: ION EXCHANGE PROCESS FOR } \\ \text { Document Title: } & \text { SEPARATION OF CESIUM FROM HANFORD TANK WASTE USING }\end{array}$ RESORCINOL-FORMALDEHYDE RESIN

Release Date: $\quad 12 / 21 / 94$

This document was reviewed following the procedures described in WHC-CM-3-4 and is:

APPROVED FOR PUBLIC RELEASE

WHC Information Release Administration Specialist:

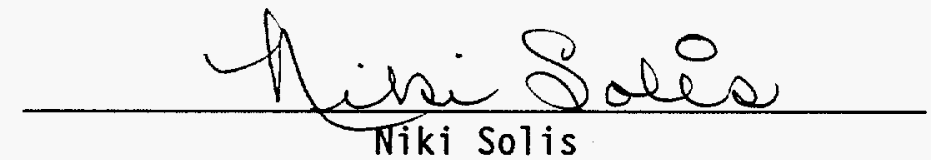

$12 / 21 / 94$

TRADEMARK DISCLAIMER. Reference herein to any specific commercial product, process, or service by trade name, trademark, manufacturer, or otherwise, does not necessarily constitute or imply its endorsement, recommendation, or favoring by the United States Government or any agency thereof or its contractors or subcontractors.

This report has been reproduced from the best available copy. Available in paper copy and microfiche. Printed in the United States of America. Available to the U.S. Department of Energy and its contractors from:

U.S. Department of Energy

Office of Scientific and Technical Information (OSTI)

P.0. Box 62

Oak Ridge, IN 37831

Telephone: (615) 576-8401

Available to the public from:

U.S. Department of Commerce

National Technical Information Service (NTIS)

5285 Port Royal Road

Springfield, VA 22161

Telephone: '(703) 487-4650 


\section{SUPPORTING DOCUMENT}

1. Total Pages $1 \frac{15}{6} 8$

2. Title

Preliminary Flowsheet: Ion Exchange for Separation of Cesium from Hanford Tank Waste Using

Resorcinol-Formaldehyde Resin

5. Key Words

Cesium Removal, Ion Exchange, Pretreatment, Resorcinol-Formaldehyde Res in, Low-Level Waste, High-Level Waste, Flowsheet, Neutralized Current Acid Waste, Double Shel1 Slurry Feed

3. Number

WHC-SD-WM-TI-638

4. Rev No.

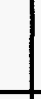

6. Author

Name: D. L. Penwe11

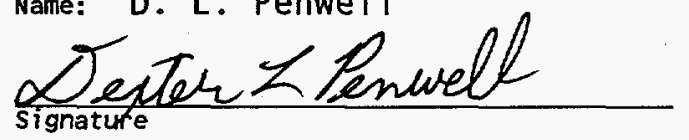

Organization/Charge Code 7E320/D3H1A

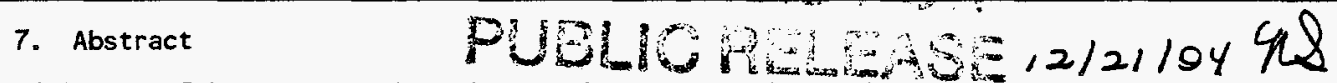

This preliminary flowsheet document describes an ion exchange process which uses resorcinol-formaldehyde (R-F) resin to remove cesium from Hanford Tank Waste. The flowsheet describes one possible equipment configuration, and contains mass balances based on that configuration with feeds of Neutralized Current Acid Waste, and Double Shell slurry Feed. The flowsheet also discusses process alternatives, unresolved issues, and development needs associated with the ion exchange process. It is expected that this flowsheet will evolve as open issues are resolved and progress is made on development needs.

8. P PPOSE AND USE OF DOCUMENT - This ofcument was prepared for use Wh in the U.S. Department of Energy 8 and its contractors. It is to be ised only to perform, difect, or integrate works under U.S. epartment of Energy contragts. This document is not gefoved for p. vic release until reviekgle.

PATENT ATus - This documitht copy, $s$ ce it is trafismitted in advance d patent clearance' is made avaik. for use in performance of work underkytracts with the U.S. Depart nt of Energy/. This document is not olfe published nor its contents therwise dísseminated or used for topes other than specified abo beforepatent approval for such, the or use has been secured, $i$ on request, from the Patent Coungel, 3. . Department of Energy Field fice, Richland, WA.

DISCLAIMER - Thi report was prepared a an accound work sponsored by an aget of the United Statesolovernment. Ne United states Govern. nt nor any agency tereof, nor any orstheir employees, norfany of their contractors/ subcontractors or their employees, makes any $w$ ranty, express 1 implied, or assumes any legal liability or respo-ibility for thy accuracy, completeness, or any third party's use or a results of fuch use of any information, apparatus froduct, or proc s disclos, or represents that its use would not finfringe privatel ${ }^{*}$ wned rigits. Reference herein to any specifie, commercial product, process, or service by trade name, trademgrk, manufacturer, or otherwise, does not necessarily consultute or imply its endorse $\mathrm{nt}$, recommendation, or favoring by theofunited States Government $r$ any agency thereof or its cc) Fractors or subcontractors. views and opinions of authors fressed herein do not necessarif state or reflect those of the United States Government or any agency thereof.

9. Impact Level $N / A$

10. RELEASE STAMP

OFFHCIA REILAE: BV DATE DEC 281994

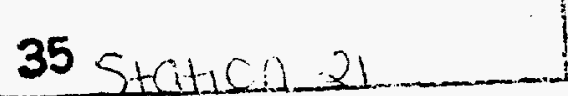

\section{DISCLAIMER}

This report was prepared as an account of work sponsored by an agency of the United States Government. Neither the United States Government nor any agency thereof, nor any of their employees, makes any warranty, express or implied, or assumes any legal liability or responsibility for the accuracy, completeness, or usefulness of any information, apparatus, product, or process disclosed, or represents that its use would not infringe privately owned rights. Reference herein to any specific commercial product, process, or service by trade name, trademark, manufacturer, or otherwise does not necessarily constitute or imply its endorsement, recommendation, or favoring by the United States Government or any agency thereof. The views and opinions of authors expressed herein do not necessarily state or reflect those of the United States Government or any agency thereof. 


\section{DISCLAIMER}

Portions of this document may be illegible in electronic image products. Images are produced from the best available original document. 
PRELIMINARY FLOWSHEET: ION EXCHANGE PROCESS FOR SEPARATION OF CESIUM FROM HANFORD TANK WASTE USING RESORCINOL-FORMALDEHYDE RESIN

WHC-SD-WM-TI-638 Rev. 0

\author{
D. L. Penwel1 \\ K. M. Eager \\ B. J. Knutson \\ Westinghouse Hanford Company \\ Richl and, Washington
}

December 1994 
WHC-SD-WM-TI-638 REV 0

This page intentionally left blank. 


\section{CONTENTS}

1.0 INTRODUCTION .................... . . . . .

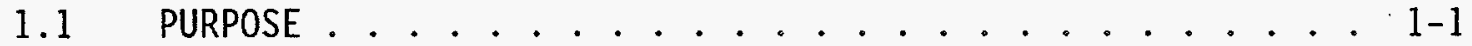

1.2 BACKGROUND ...................... . . . . . .

1.3 Ion Exchange System .............. 1-2

2.0 SUMMARY ........................ 2-1

2.1 PROCESS SUMMARY .............. . . 2-1

2.2 ISSUES TO BE RESOLVED BY TESTING/DEVELOPMENT . . . . . 2-7

3.0 FLOWSHEET BASES ................... . . . . .

3.1 CESIUM ION EXCHANGE PROCESS ............ $3-1$

3.2 CESIUM REMOVAL REQUIREMENTS ............ $3-1$

3.3 ION EXCHANGE PROCESS CAPACITY ........... $3-2$

3.4 ION EXCHANGE PROCESS FEED .......... $\ldots 3-2$

3.5 RETRIEVAL, SLUDGE WASH, DECANT, AND FILTRATION . . . . 3-2

3.6 CESIUM LOADING ....................... $3-3$

3.7 CESIUM ELUTION FROM RESIN ............... $3-3$

3.8 RESIN REPLACEMENT . . . . . . . . . . . . 3-3

3.9 LOW LEVEL WASTE . . . . . . . . . . . . . . 3-3

4.0 PROCESS DESCRIPTION . . . . . . . . . . . . . . . 4-1

4.1 RETRIEVE, SLUDGE WASH, DECANT, EVAPORATE, AND FILTER . . . 4-1

4.2 CESIUM ION EXCHANGE . . . . . . . . . . . 4-5

4.2 .1 Column Loading . . . . . . . . . . . . 4-6

4.2.2 Post Load Wash . . . . . . . . . . . . 4-7

4.2 .3 Elution................ 4- . . . . .

4.2.4 Water Wash . . . . . . . . . . . 4-7

4.2 .5 Regeneration ............. 4-8

4.2.6 Resin Change Out ............ . 4-8

4.2.7 Resin Preparation for Storage and Disposal . . . 4-9

4.2.8 Elution Acid Recovery . . . . . . . . . . 4-9

5.0 PROCESS TECHNOLOGY .................. . . 5-1

5.1 CHEMISTRY . . . . . . . . . . . . . . . 5-1

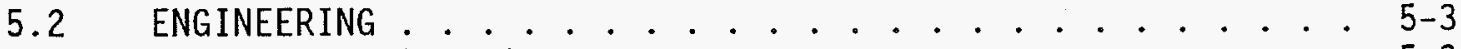

5.2 .1 One-Pass System ........... . . 5-3

5.2 .2 Column Configuration ............ 5-3

6.0 PROCESS CONTROL . . . . . . . . . . . . . . . 6-1

6.1 GENERAL . . . . . . . . . . . . . . . . . . 6-1

6.2 OUTLET STREAM MONITORING . . . . . . . . . . . . 6-1

6.3 VALVE FAILURE MODE .............. . . 6-1

6.4 TEMPERATURE CONTROL .............. . . 6-2

6.5 CONTROL OF NITRIC ACID TO THE COLUMNS ........ $6-2$

7.0 OFF-STANDARD CONDITIONS ................. . . . .

7.1 NITRIC ACID CONCENTRATION . . . . . . . . . . 7-1

7.2 LOSS OF FLOW TO A PARTIALLY OR FULLY LOADED COLUMN . . . 7-1

7.3 VALVE LEAKS................. . . $7-2$

7.4 PUMP FAILURE ..................... $7-2$ 
WHC-SD-WM-TI-638 REV 0

CONTENTS (Continued)

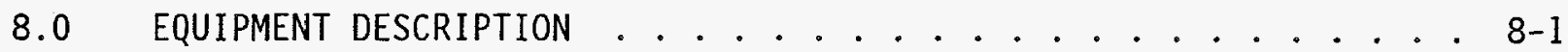

8.1 EQUIPMENT SIZES . ............. . . . . . .

8.1 .1 Resin Bed Size ........... 8-1

8.2 MATERIALS OF CONSTRUCTION . . . . . . . . . 8-4

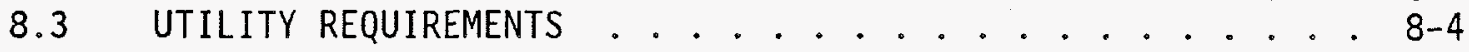

9.0 SAFETY AND REGULATORY ................. . . 9-1

9.1 HEALTH ............................ 9.1

9.1.1 Exposure to Chemicals .......... 9-1

$9.2 \quad 9.1 .2$ Radiological Exposure .......... 9-1

9.2 CHEMICAL SAFETY .................. 9-1

9.2.1 Resorcinol-Formaldehyde Resin ........ 9-1

9.2 .2 Nitric Acid.............. 9-4

9.2.3 Sodium Hydroxide . . . . . . . . . . . 9-4

9.3 ENVIRONMENTAL CONCERNS . . . . . . . . . . . . . 9-5

10.0 ESSENTIAL MATERIALS . . . . . . . . . . . . . 10-1

10.1 RESORCINOL-FORMALDEHYDE RESIN .......... . . 10-1

10.2 NITRIC ACID . . . . . . . . . . . . . . $10-4$

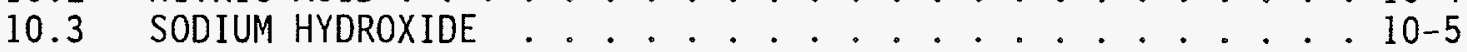

11.0 PROCESS ALTERNATIVES .................. . . . . . . .

11.1 ION EXCHANGE MATERIALS ............... 11-1

11.1.1 Comparison of Resorcinol-Formaldehyde Resin

to CS-100 Resin ............ . 11-1

11.211 .2 Other Types of Ion Exchange Materials ..... 11-4

11.3 ELUTION TEMPERATURE $\ldots \ldots \ldots$

11.4 SODIUM CONCENTRATION IN COLUMN FEED . . . . . . . . 11-6

11.5 ELUENT . . . . . . . . . . . . . . . 11-6

11.6 CONCENTRATION OF SODIUM HYDROXIDE REGENERATION SOLUTION . . 11-6

11.7 AMOUNT OF SODIUM HYDROXIDE REGENERATION SOLUTION . . . 11-7

11.8 SODIUM HYDROXIDE RINSE AT THE END OF EACH FEED CYCLE . . . 11-7

11.9 COLUMN CONFIGURATION ................ . . . . . .

11.9.1 Number of Ion Exchange System Passes . . . . . . . 11-7

11.9.2 Number of Ion Exchange Columns in System . . . . 11-8

11.9.3 Polishing Column ............ . . 11-8

11.10 FILTERS . . . . . . . . . . . . . . . . . 11-9

12.0 PROCESS MATERIAL BALANCES AND FLOW DIAGRAMS . . . . . . . 12-1

12.1 NCAW MATERIAL BALANCE ........... . . . . . 12-1

12.2 DOUBLE-SHELL SLURRY FEED MATERIAL BALANCE . . . . . . 12-21

13.0 ISSUES AND CONCERNS . . . . . . . . . . . . . . 13-1

13.1 GENERAL ISSUES ..................... $13-1$

13.2 ISSUES ASSOCIATED WITH THE RESORCINOL-FORMALDEHYDE RESIN * 13-1

13.2.1 Clumping of Resorcinol-Formaldehyde Resin . . . . 13-1

13.2.2 Residual Cesium on the Ion Exchange Resin .....13-2

13.2.3 Resin Degradation in a Caustic Environment ... . 13-3 


\section{WHC-SD-WM-TI-638 REV 0 \\ CONTENTঙ (Continued)}

13.3 CESIUM ION EXCHANGE FEED ............. . . 13-3

13.3.1 Competing Trace Chemicals In Waste ...... 13-3

13.3.2 Competing Chemicals from Group $1 A$ of the

Periodic Table .......... . . . 13-4

13.3 .3 Organics in the Ion Exchange Feed ....... 13-4

13.4 FILTRATION ................ . . . . . . . . .

13.5 FOULING OF RESIN $\ldots 13-5$

13.6 SODIUM HYDROXIDE RINSE AT END OF EACH FEED CYCLE . . . . 13-5

13.7 EVAPORATION ENERGY ............... . . . . . . . . .

13.8 OPERATION OF 3 COLUMNS IN SERIES . . . . . . . . . . 13-5

13.9 NUMBER OF ION EXCHANGE SYSTEM PASSES . . . . . . . . 13-6

14.0 PROCESS DEVELOPMENT . . . . . . . . . . . . . 14-1

15.0 REFERENCES . . . . . . . . . . . . . 15-1

\section{APPENDIXES}

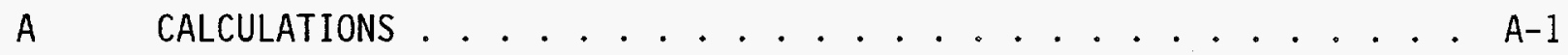

B SELECTION OF CS-100 RESIN AS BASELINE ION EXCHANGER . . . . B B-1 


\section{LIST OF FIGURES}

2-1 Simplified Process Flow Diagram for TWRS Cesium Ion Exchange Using Resorcinol-Formaldehyde Resin, Neutralized Current

Acid Waste.................... . . 2-3

2-2 Simplified Process Flow Diagram for TWRS Cesium Ion Exchange Using Resorcinol-Formaldehyde Resin, Double-Shell Slurry Feed . 2-5

4-1 TWRS Cesium Ion Exchange Process Flow Diagram . . . . . . 4-3

5-1 Operation of a Four Column "Carouse1" System . . . . . . . . 5-5

10-1 Chemical Structure of Resorcinol-Formaldehyde Resin ..... . 10-3

12-1 TWRS Cesium Ion Exchange Process Flow Diagram . . . . . . . 12-3 


\section{LIST OF TABLES}

3-1 Summary of ${ }^{137} \mathrm{Cs}$ Decontamination Factors, for ResorcinolFormaldehyde Ion Exchange Process, NCAW and DSSF Waste . . . . . 3-1

4-1 Summary of Column Operations per Cycle for Neutralized Current Acid Waste. ................ . . . 4-5

4-2 Summary of Column Operations per Cycle for Double-Shell Slurry Feed. . . . . . . . . . . . . . . . 4-6

8-1 Cesium Ion Exchange Equipment List . . . . . . . . . . . 8-2

9-1 Recommended Precautions When Using IX Resins . . . . . . . . 9-3

10-1 Particle Size Distribution for Resorcinol-Formaldehyde Resin . . . 10-1

10-2 Physical Properties of R-F Resin ............. 10-2

11-1 Comparison of Waste and Chemical Streams for Neutralized Current Acid Waste Treatment . . . . . . . . . . . 11-2

11-2 Comparison of Waste and Chemical Streams for Neutralized Current Acid Waste Treatment . . . . . . . . . . . . 11-3

12-1 Cesium Ion Exchange, Neutralized Current Acid Waste, Resorcinol-Formaldehyde Resin, Major Process

Stream Data . . . . . . . . . . . . . . . . . 12-5

12-2 Cesium Ion Exchange, Neutralized Current Acid Waste, Resorcinol-Formaldehyde Resin, Major Process

Stream Data ................... . . . 12-7

12-3 Cesium Ion Exchange, Neutralized Current Acid Waste, Resorcinol-Formaldehyde Resin, Major Process

Stream Data .. . . . . . . . . . . . . . . . . 12-9

12-4 Cesium Ion Exchange, Neutralized Current Acid Waste, Resorcinol-Formaldehyde Resin, Major Process

Stream Data

12-5 Cesium Ion Exchange, Neutralized Current Acid Waste, Resorcinol-Formaldehyde Resin, Major Process

Stream Data . . . . . . . . . . . . . . . . . 12-13

12-6 Cesium Ion Exchange, Neutralized Current Acid Waste, Resorcinol-Formaldehyde Resin, Major Process

Stream Data

12-7 Cesium Ion Exchange, Neutralized Current Acid Waste, Resorcinol-Formaldehyde Resin, Major Process

Stream Data 


\section{LIST OF TABLES (Continued)}

12-8 Cesium Ion Exchange, Neutralized Current Acid Waste, Resorcinol-Formaldehyde Resin, Major Process

Stream Data................. . . 12-19

12-9 Cesium Ion Exchange, Double-She11 Slurry Feed, Resorcinol-Formaldehyde Resin, Major Process

Stream Data .................. 12-23

12-10 Cesium Ion Exchange, Double-Shel1 Slurry Feed, Resorcinol-Formaldehyde Resin, Major Process Stream Data ................ 12-25

12-11 Cesium Ion Exchange, Double-Shell Slurry Feed, Resorcinol-Formaldehyde Resin, Major Process Stream Data . . . . . . . . . . . . . . . 12-27

12-12 Cesium Ion Exchange, Double-Shell Slurry Feed, Resorcinol-Formaldehyde Resin, Major Process Stream Data ............... . . 12-29

12-13 Cesium Ion Exchange, Double-She11 Slurry Feed, Resorcinol-Formaldehyde Resin, Major Process Stream Data ................ . . 12-31

12-14 Cesium Ion Exchange, Double-Shel1 Slurry Feed, Resorcinol-Formaldehyde Resin, Major Process Stream Data . . . . . . 12-33

12-15 Cesium Ion Exchange, Double-She11 Slurry Feed, Resorcinol-Formaldehyde Resin, Major Process Stream Data ................. . . 12-35

12-16 Cesium Ion Exchange, Double-She11 Slurry Feed, Resorcinol-Formaldehyde Resin, Major Process Stream Data 


\section{LIST OF TERMS}

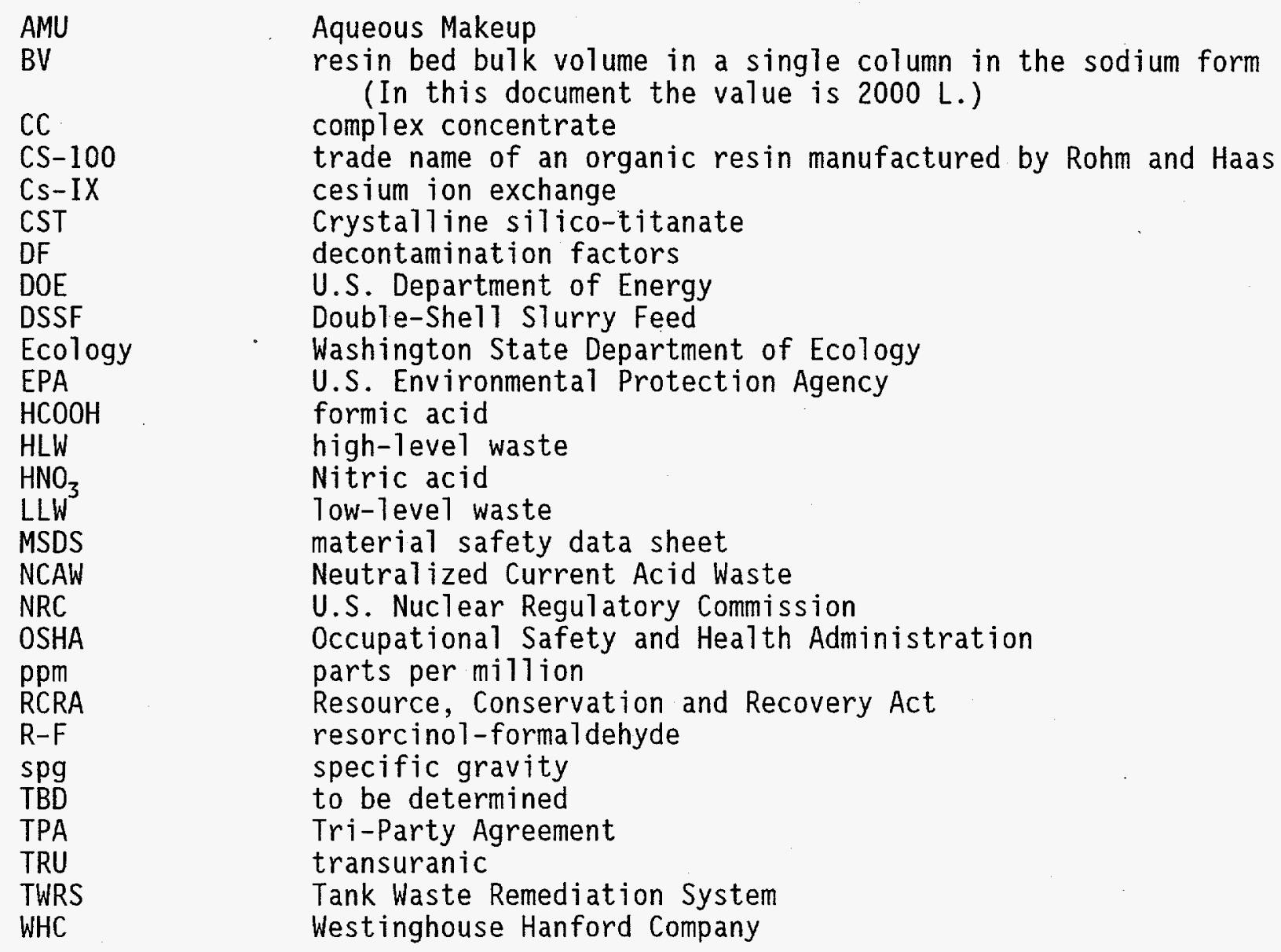




\section{WHC-SD-WM-TI-638 REV 0}

This page intentionally left blank. 


\subsection{INTRODUCTION}

\subsection{PURPOSE}

The purpose of this document is to provide the preliminary flowsheet for an ion exchange process which would separate cesium from Hanford Site tank waste using resorcinol-formaldehyde (R-F) ion exchange resin. This process flowsheet supports goals defined by the revised Hanford Federal Facility Agreement and Consent Order also known as the Tri-Party Agreement (TPA), of January, 1994 (Ecology et al. 1994), the Hanford Tank Waste Remediation System Technical Strategy (Alumkal 1994), Functions and Requirements for Project W236B, Initial Pretreatment Module (Swanson 1994), and the TWRS Process Flowsheet (Orme 1994), by serving as a lower level functional flowsheet to provide more technical detail on the cesium ion exchange (Cs-IX) process. The issuing of this flowsheet document, along with a companion flowsheet document, WHC-SD-WM-TI-667, (Eager and Penwe11 1994), which addresses cesium separation using Duolite ${ }^{*}$ CS-100 resin, satisfy TPA Milestone M-50-01-T01 and completes the Westinghouse Hanford Company (WHC) fiscal year 1994 work breakdown structure 1.1.2.3.2.1.1 milestone entitled "Issue a Resorcinol-Formaldehyde Flowsheet Document."

The R-F and CS-100 flowsheet documents were developed in parallel. They use the same format and are similar in content. The resin comparison section (Section 11.1.1) in both reports is the same.

\subsection{BACKGROUND}

In 1989 the U.S. Department of Energy (DOE), Washington State Department of Ecology (Ecology), and the U.S. Environmental Protection Agency (EPA) signed the original TPA (Ecology et al. 1989). The TPA established a strategy, schedule, and milestones for disposal of the waste in the Hanford Site single- and double-shell tanks.

In order to provide more detailed plans and strategies to meet the goals of the TPA, the Tank Waste Remediation System (TWRS) organization has issued the following two documents: (1) the Hanford Tank Waste Remediation System Technical Strategy (Alumkal 1994), and (2) the TWRS Process Flowsheet, (Orme 1994).

The general strategy for the processing of Hanford tank waste as outlined by these two documents includes waste retrieval, in-tank sludge washing and caustic leaching, separation of the waste into two distinct waste streams, cesium removal from the low-level waste (LLW), immobilization of high-level waste (HLW), and immobilization of cesium depleted LLW. Retrieval of both waste supernates and sludges is accomplished primarily by sluicing and pumping. In-tank sludge washing and caustic leaching reduce the mass of suspended solids. Waste is separated into two distinct process streams: a high-level radioactive waste stream, which contains most of the suspended solids, and a low level radioactive waste stream, which consists of decanted,

\footnotetext{
*Duolite is a trademark of Rohm and Haas Inc.
} 
filtered supernates, leachates, and wash solutions. Cesium is removed from the $L L W$ by ion exchange to reduce radioactivity, and the LLW is vitrified. HLW is immobilized by vitrification. The vitrified HLW is poured into steel canisters, cooled, and sealed.

\subsection{Ion Exchange System}

There are many types of ion exchange system configurations that are possible. The ion exchange column configuration used for this flowsheet is a single-pass system that has three columns in series online at any time. This configuration was chosen for this flowsheet as a compromise. It is a trade off between simplicity with greater secondary waste generation, and the type of multiple-pass system which may be required to achieve the decontamination factors (DFs) required for achieving a class $A$ end product.

This flowsheet, and the companion flowsheet document for CS-100, use the same configuration. This makes comparison of the two resins much easier. 


\subsection{SUMMARY}

\subsection{PROCESS SUMMARY}

The cesium ion-exchange (Cs-IX) process described by this flowsheet is a one-pass, regenerative, ion exchange process to remove cesium from feeds of neutralized current acid waste (NCAW), and double-she 11 slurry feed (DSSF). Greater than $99 \%$ of the original cesium in the Cs-IX feed is removed from the NCAW and DSSF ion-exchange feeds. This degree of cesium removal is based on producing a final LLW glass form that is capable of meeting the U.S. Nuclear Regulatory Commission (NRC) Class $A$ requirement for ${ }^{137} \mathrm{Cs}$, which is $1 \mathrm{Ci}$ ${ }^{137} \mathrm{Cs} / \mathrm{m}^{3}$ of LLW form (10 CFR 61.55). The same process equipment system is used for both the NCAW and the DSSF feeds. The process is sized to process all Hanford Site single- and double-shell tank waste in 14 years. At a total operating efficiency of $60 \%$, about 48 days wi17 be needed to process the NCAW, and about 752 days (just over two years) to process the DSSF. The ion exchange calculations are based upon sodium, potassium, and cesium only. Al1 radiological calculations are based on only ${ }^{137} \mathrm{Cs}$. The resin is eluted with $0.5 \mathrm{M} \mathrm{HNO}_{3}$ and regenerated with dilute solutions of sodium hydroxide.

NCAN and DSSF waste types have been selected as feeds because they are assumed to represent bounding cases. NCAW has the highest cesium concentration of any Hanford single- or double-shell tank waste. DSSF has a high potassium concentration relative to most Hanford single- and double-shell tanks wastes. The processing parameters of other waste types are estimated to fall within the limits set by NCAW and DSSF. Loading and elution models currently being developed may aid in determining the impact of other wastes to be processed.

Many design configurations are possible to meet these processing requirements. The process design configuration presented in this flowsheet represents one configuration with which other configurations may be compared. This configuration should be considered preliminary.

The process presented in this flowsheet is a one-pass system, which means that the ion exchange feed passes through the ion exchange columns one time only under normal operating conditions while producing a cesium-depleted LLW. In general, one-pass systems are simpler to operate and maintain, and have a lower capital cost than multi-pass systems. But, multi-pass systems are capable of achieving higher degrees of cesium separation (i.e., higher decontamination factor [DF]).

The CS-IX process consists of four ion exchange columns in total, configured in a "carousel" configuration. Three columns connected in series process CS-IX feed, while the fourth column is off 1 ine being eluted, and regenerated. Each resin bed within the column contains about 2,000 $L$ of sodium form $R-F$ resin (see Section 11.1 for a comparison of R-F resin to CS100 resin). Columns are designed with length (L) of $213 \mathrm{~cm}$, a diameter (D) of $108 \mathrm{~cm}$, for a length to diameter $(L / D)$ ratio of 2.0 .

Simplified process flow diagrams which include overall mass balances for the processing of all the NCAW and DSSF waste are shown in Figure 2-1 (NCAW) and Figure 2-2 (DSSF). 
WHC-SD-WM-TI-638 REV 0

This page intentionally left blank. 
TETEY SLUDCE WASHED WASTE SUPERMATE

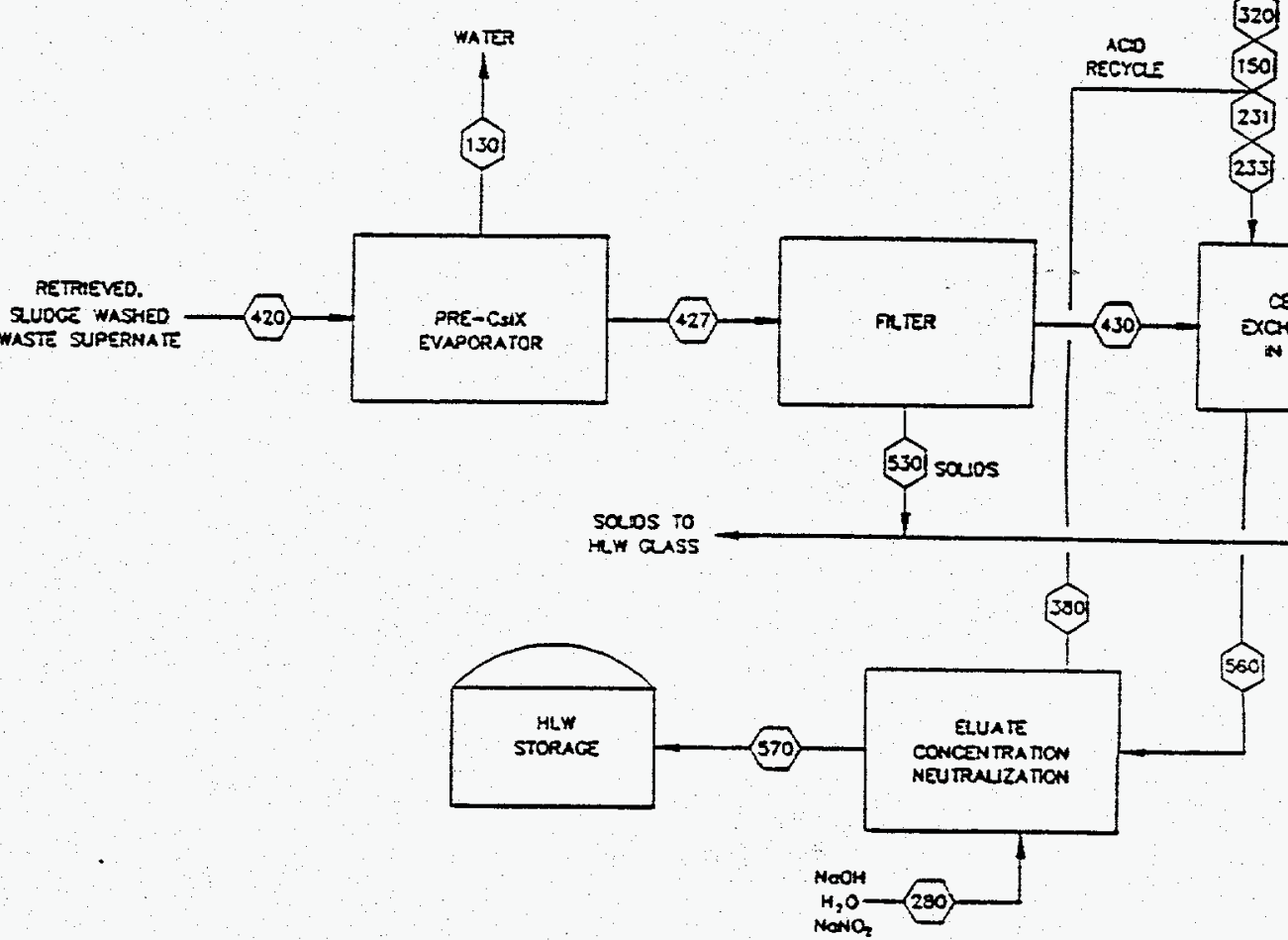

(1400)

320

so)

311)

33. 
HNO, SOUHONS FOR IIUTKONS

WOH SOUUTOAS FOR RECENERA TONS WATER WASHES

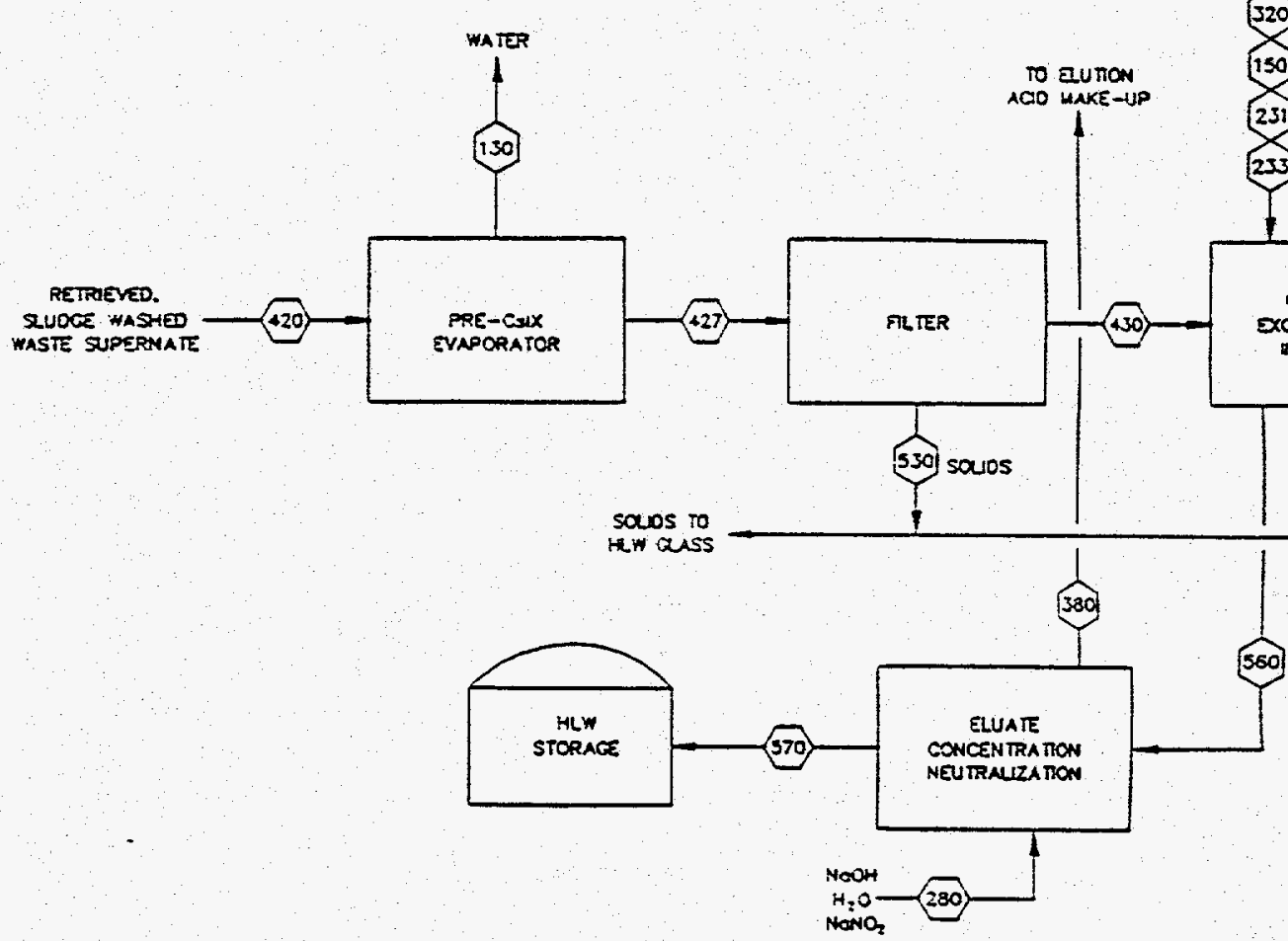

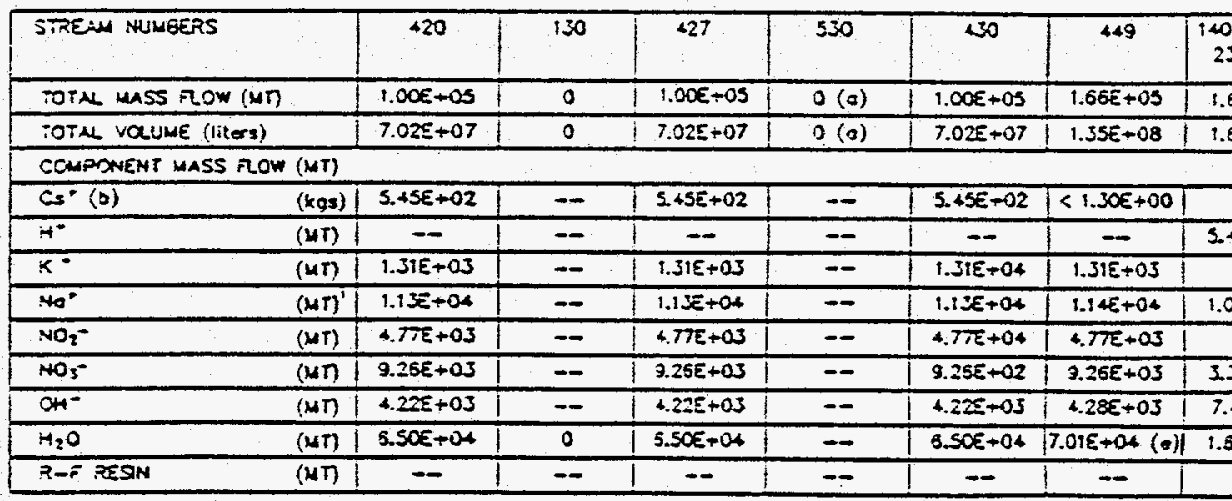

(a) MASS ANO VOUUWE OF FLLERED SOUDS ARE ASSUMMED TO BE ZERO FOR THIS FLOWSHEET. SOME AMOUNT OF SOUOS ANO FUUSHING WATER ARE EXPECTED IN REAL OPERAIIN.

(b) INCLUES ALL isOTOPES of CESUM

(c) 110,900 UTERS OF ORY R-F RESN IN THE K FORM (AS RECOVED) (.892 kg/iters)

(d) 112.000 UTERS OF ORY RTF RESN IN THE No FORM (.461 kg/liters)

(ध) 15.4 UT HZO ARE FORMEO DURING RECENERATON 
Figure 2-2. Simplified Process Flow Diagram for TWRS Cesium Ion Exchange Using Resorcinol-Formaldehyde Resin, Double-Shell slurry Feed.

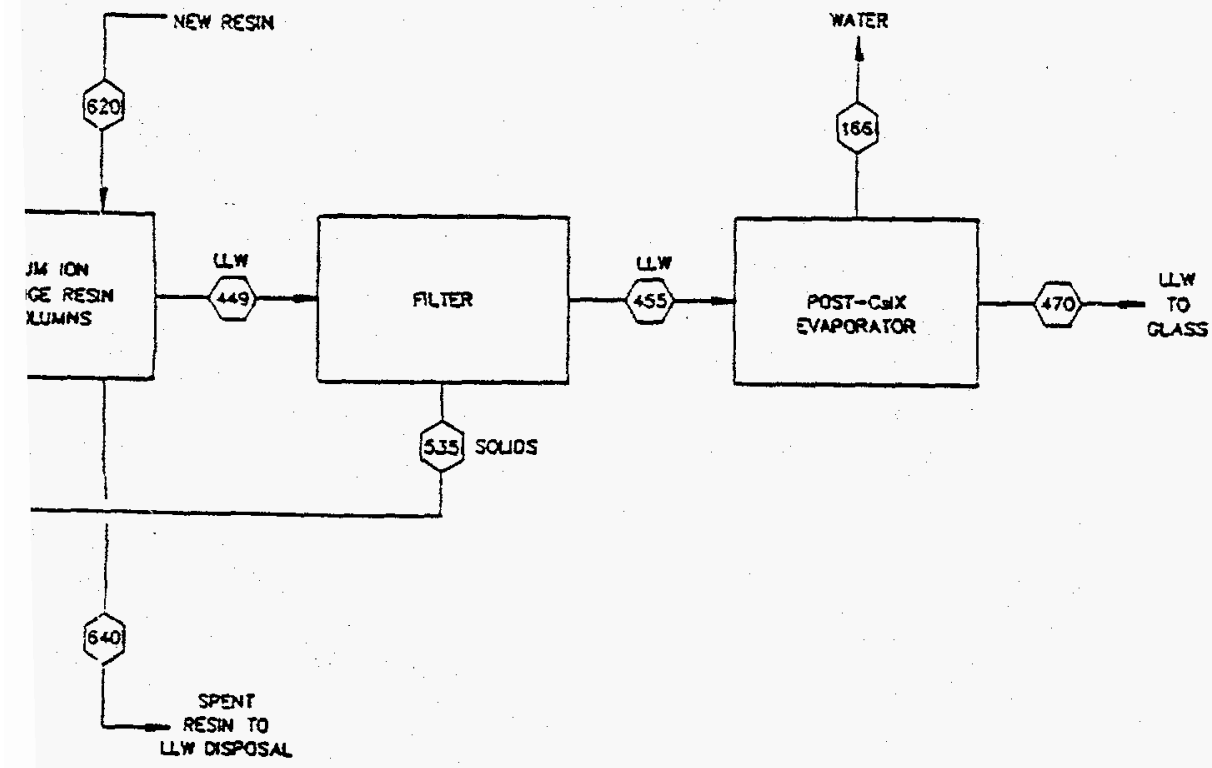

\begin{tabular}{|c|c|c|c|c|c|c|c|c|c|c|}
\hline $\begin{array}{l}50 \\
5\end{array}$ & 560 & 380 & 280 & 570 & 620 & 640 & 535 & 455 & 286 & 470 \\
\hline 4 & $2.16 \mathrm{E}+04$ & $1.07 E+04$ & $1.08 E+02$ & $5.12 \Sigma+02$ & $250 E-32$ & $1.30 E-02$ & $0(0)$ & $1.56 \mathrm{E}+05$ & $258 E+04$ & $7.98 E+04$ \\
\hline \multirow[t]{2}{*}{7} & $\therefore 1+07$ & $1.06 \mathrm{E}-07$ & $1.25 E+05$ & $3.37 E+05$ & $2 \pi \pi \div 04$ & $2.80 \varepsilon+04$ & $0(0)$ & $1.35 E+03$ & $258 E+07$ & $6.965+07$ \\
\hline & $5.445+02$ & troce & -- & 544 & - & -- & 0 & $<1.30 E+100$ & $-\infty$ & $<1.30 E+\infty 0$ \\
\hline \multirow[t]{8}{*}{ 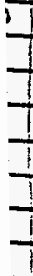 } & $+.59 \varepsilon+\infty$ & 3.21 & - & $=$ & -- & $=$ & 0 & $-\infty$ & +- & $-\infty$ \\
\hline & $.01 E+01$ & $-\infty$ & -- & $1.01 E+01$ & - & - & 0 & $1.51 \varepsilon+03$ & $=$ & $1.3 t E+03$ \\
\hline & $\therefore .25 E+0 t$ & -- & 1.26E+01 & $5.51 E+01$ & - & - & 0 & $1.14 E+04$ & - & $1.1+E+04$ \\
\hline & - & $=$ & $1.60+E 01$ & $1.80 \varepsilon+0 r$ & - & - & 0 & $4.772+03$ & $-\infty$ & $4.77 \varepsilon+03$ \\
\hline & $376+02$ & 1.99502 & -- & $\therefore .32 E+02$ & $=-$ & $=$ & 0 & $9.26 E+0.3$ & $=$ & $9.25 E+03$ \\
\hline & $-=$ & - & $255 e+01$ & 215 & 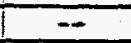 & $=$ & 0 & $4.282+0.5$ & -- & $4.29 \varepsilon+0.3$ \\
\hline & $8.12 E+04$ & $1.05 E+04$ & $9.52 E+01$ & $281 E+02$ & $=$ & -- & 0 & $7.01 \varepsilon+04(5)$ & $2.58 E+04$ & $4+45+04$ \\
\hline & - & $\rightarrow$ & - & $-\infty$ & $8.98 \varepsilon+01\{c\}$ & $5.16 E+09(4)$ & - & -- & $-\infty$ & -- \\
\hline
\end{tabular}


The NCAW or DSSF waste is retrieved by pumping liquids and sluicing solids. The solids are washed, allowed to settle, and the liquid portion (supernate) decanted. Repeated wash, settle, decant cycles may be performed. Caustic washing solutions may be used to reduce solids volumes by leaching.

The DSSF waste is diluted to a nominal $7 M$ sodium concentration to prevent solids precipitation in the Cs-IX process. The NCAW supernate solution is evaporated to a nominal $5 \mathrm{M}$ sodium concentration to reduce tank storage and processing volume requirements. Evaporated water is recycled for further waste retrieval and sludge washing. The solutions are cooled to about $25{ }^{\circ} \mathrm{C}$ and passed through a filter to further reduce the amount of suspended solids before being fed to the Cs-IX columns.

The ion exchange system is designed for a flowrate of $108 \mathrm{~L} / \mathrm{min}$ through the ion exchange columns. An average of 180 bed volumes (at 2,000 L per column $=360,000 \mathrm{~L}$ ) of NCAW Cs-IX feed solution can be processed before the lead column must be taken off line for elution (129 bed volumes, or $258,000 \mathrm{~L}$ for the DSSF). A bed volume as used in this document refers to the volume occupied by the sodium form of the resin in each column, in this case 2,000 L. The high concentration of potassium in the DSSF Cs-IX feed reduces the volume of waste processed and the amount of cesium loaded on the resin at the breakthrough point. At the breakthrough point an average of

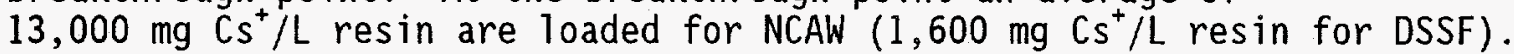
The cesium-depleted IX product is filtered, sampled, and analyzed for product approval. Approved batches are evaporated to a sodium concentration of $10 \mathrm{M}$ and stored as feed for the LLW vitrification facility.

The cesium breakthrough point is determined with the aid of onl ine gamma monitors. At the breakthrough point the loaded lead column is taken off line, washed with water or caustic solution, eluted with $0.5 \mathrm{M} \mathrm{HNO}_{3}$ at $25{ }^{\circ} \mathrm{C}$, washed again with water, and then regenerated with $0.5 \mathrm{M}$ and $2.0 \mathrm{M}$ sodium hydroxide solutions. More than $99 \%$ of the loaded cesium is removed from the resin bed with 10.0 gmole $H^{+} / L$ R-F resin. The $\mathrm{CS}-\mathrm{IX}$ eluate is concentrated to about $7 \mathrm{M}$ nitrate in a nitric acid evaporator. The overhead acid and water are recycled back to eluant make-up tanks, to be used again for subsequent column elutions. Seventy (70) percent of the eluate acid is recovered. Concentrated eluate is neutralized and sent to HLW storage.

The ion exchange system shown in this document can be used to process waste using different types of ion exchange materials. This ability to use different materials provides a significant advantage at very little cost.

\subsection{ISSUES TO BE RESOLVED BY TESTING/DEVELOPMENT}

During the development of this flowsheet, many significant items were identified associated with cesium removal by ion exchange. The key issues are mentioned briefly below. Further details may be obtained by studying the appropriate sections of this document. A more complete 1ist of major testing and development needs is developed in Section 14.0, Process Development. 
A one-pass system has been shown to achieve very high DFs on a laboratory scale with waste simulants, using fresh (i.e., previously unused) resin. However, the ability of a full scale, one-pass regenerable system to continuously meet the cesium removal requirements, in operation with real waste has been questioned. A multi-pass regenerable system has a greater likelihood of meeting the cesium removal requirements with the needed margin of success. Therefore, multiple passes, and possibly a non-regenerable polishing column, may be needed to achieve the required cesium decontamination factors.

The performance of the Cs-IX process will be significantly affected by competing ions in the feed such as sodium, potassium, and rubidium.

Testing to date has shown that some soluble organic chelating agents do not affect resin performance. However, the affects of all types of soluble and separate phase organics need to be tested.

The $\mathrm{R}-\mathrm{F}$ resin can be dissolved using $3 \mathrm{M} \mathrm{HNO}_{3}$. The safety significance of this is not known. Further evaluation of the reaction of $\mathrm{R}-\mathrm{F}$ resin with $\mathrm{HNO}_{3}$ is needed.

Storage and disposal methods for spent resin need to be developed.

To prevent potentially hazardous exothermic reactions within the column vessels, extreme care must be taken to prevent nitric acid concentrations greater than $1 M$ from contacting the ion exchange resin. The severity of the safety problems associated with contact between the organic resin and nitric acid concentrations greater than $1 M$ has not been resolved. Testing to determine the severity of the reaction needs to be performed. In addition, the column design also affects the severity of the safety problems associated with the reaction because it determines the amount of resin that is available to react, and whether the system can cope with the heat and gas generated during an exothermic excursion.

The decay heat in an ion exchange column fully loaded with NCAW feed can be up to $5.96 \times 10^{3}$ watts. If no cooling is present, this can heat the column to the point at which significant resin degradation occurs. The system design must account for this safety item.

The ion exchange columns will require significant shielding as well as remote maintenance capabilities because the contact radiation fields will be as great as $2.7 \times 10^{5} \mathrm{Rad} /$ hour.

Clumping of R-F resin occurred during elution testing. This causes channelling and poor elution. This issue must be resolved before R-F resin is used in a full scale radioactive process.

This flowsheet was conservative with regard to the amount of regeneration chemicals, and possibly also with regard to the amount of eluant. Testing needs to be performed to optimize amounts of both solutions, which will minimize the amount of secondary waste generated. 
Although filters are shown in this flowsheet, the filtration requirements still need to be developed.

The following process alternatives need further consideration:

- Formic acid for elution

- Other ion exchangers, such as CS-100 resin and crystalline silico-titanates

- A multi-pass system or a single pass system with a polishing column

- Alternative column configurations (carousel and non-carousel). 
WHC-SD-WM-TI-638 REV 0

This page intentionally left blank. 


\subsection{FLOWSHEET BASES}

The following are discussions of the major bases and assumption used to develop this process flowsheet.

\subsection{CESIUM ION EXCHANGE PROCESS}

Multiple ion exchange columns are used in series in a "carousel" arrangement. The "carousel" system is described in section 5.2.2. Product specifications are met in a single pass of the ion exchange feed solution through the columns. $R-F$ ion exchange resin is used for the ion exchanger.

\subsection{CESIUM REMOVAL REQUIREMENTS}

All radionuclide calculations were based on ${ }^{137} \mathrm{Cs}$. Cesium is removed to produce a glass LLW form which meets U.S. Nuclear Regulatory Commission (NRC) Class A limits for ${ }^{137} \mathrm{Cs}$. The NRC Class A 1 imit for ${ }^{137} \mathrm{Cs}$ in the $\mathrm{LLW}$ waste form is met if the açtivity due to ${ }^{137} \mathrm{Cs}$ in the low level glass does not exceed $1.0 \mathrm{Ci}{ }^{137} \mathrm{Cs} / \mathrm{m}^{3}$ of $\mathrm{gl}$ ass (10 CFR 61). To meet this $7 \mathrm{imit}$, the R-F resin ion exchange process must remove $99.99 \%$ of the ${ }^{137} \mathrm{Cs}$ in the NCAW for a DF of 8,490. 99.75\% of the ${ }^{137} \mathrm{Cs}$ in the DSSF waste must be removed (DF of 400). These DFs are specific to the process described by this flowsheet because the ion exchange process adds sodium into the LLW glass form and the waste loading in the LLW form is assumed to be limited by sodium. The calculations assume that the LLW form is glass with a density of $2.6 \mathrm{MT} / \mathrm{m}^{3}$, and that the $\mathrm{glass}$ will contain $20 \%$ (wt.) $\mathrm{Na}_{2} 0$. Table $3-1$ summarizes the ${ }^{137} \mathrm{Cs}$ removal requirements for the $\mathrm{NCAW}^{2}$ and $\mathrm{DSSF}$ waste to meet the Class $\mathrm{A}$ specification.

Table 3-1. Summary of ${ }^{137}$ Cs Decontamination Factors, for ResorcinolFormaldehyde Ion Exchange Process, NCAW and DSSF Waste.

\begin{tabular}{|c|c|c|c|c|c|}
\hline $\begin{array}{c}\text { Waste } \\
\text { type }\end{array}$ & $\begin{array}{c}{ }^{137} \mathrm{Cs} \\
\text { inventory in } \\
\text { waste }(\mathrm{C} i)\end{array}$ & $\begin{array}{c}\mathrm{Na}^{+} \text {in } \\
\mathrm{CS}-\mathrm{IX} \\
\text { effluent } \\
(\mathrm{MT})\end{array}$ & $\begin{array}{c}\text { Maximum Cs } \\
\text { to } \mathrm{L} \mathrm{LW} \\
\left(\mathrm{C} i{ }^{137} \mathrm{Cs}\right)\end{array}$ & $\begin{array}{c}\text { Decontam- } \\
\text { ination } \\
\text { factor }\end{array}$ & $\begin{array}{c}\text { Percent of } \\
\text { initial } \\
{ }^{137} \mathrm{Cs} \\
\text { removed }\end{array}$ \\
\hline NCAW & $1.15 \mathrm{E}+07$ & 523 & $1.36 \mathrm{E}+03$ & 8,490 & 99.988 \\
\hline DSSF & $1.18 \mathrm{E}+07$ & $1.14 \mathrm{E}+04$ & $2.95 \mathrm{E}+04$ & 400 & 99.75 \\
\hline
\end{tabular}




\subsection{ION EXCHANGE PROCESS CAPACITY}

The CS-IX process is sized for a throughput of $108 \mathrm{~L} / \mathrm{min}$ of $5 \mathrm{M} \mathrm{Na}{ }^{+}$ diluted NCAW solution, or $108 \mathrm{~L} /$ min of $7 \mathrm{M} \mathrm{Na}{ }^{+}$diluted DSSF waste solution. This system capacity was developed in the TWRS Process Flowsheet (Orme 1994), in order to process all single- and double-shell tank waste within a 14 year period while assuming a 60 percent total operating capacity. Based upon the $108 \mathrm{~L} / \mathrm{min}$ capacity and 60 percent total operating efficiency, the NCAW would be processed in 48 days and the DSSF in just over 2 years (752 days).

\subsection{ION EXCHANGE PROCESS FEED}

Two mass balances are developed in this flowsheet. One for the processing of NCAW, and the other for the processing of DSSF waste. These feed types where selected for the following reasons: (1) sufficient characterization data exists for both waste types, and (2) the two waste types are considered to be a bounding cases in that NCAW is a high ${ }^{137} \mathrm{Cs}$ waste, and DSSF is a high potassium waste. The two bounding case mass balances provide insight into the extremes of ${ }^{137} \mathrm{Cs}$ concentrations throughout the process, and extremes of potassium competition with cesium for ion exchange site on the resin. Impacts of processing other feeds will be determined from validated loading and elution models after the models are completed.

Volume and chemical composition data for the NCAW and DSSF waste are taken from The Tank Waste Technical Options Report, Appendix D (Boomer et a1., 1993). ${ }^{137} \mathrm{Cs}$ is decayed to 1995.

\subsection{RETRIEVAL, SLUDGE WASH, DECANT, AND FILTRATION}

The amount of water and chemicals ( $\mathrm{NaOH}$ and $\left.\mathrm{NaNO}_{2}\right)$ that were used for retrieval and sludge washing of NCAW were taken from the document, Process Evaluation for In-Tank Washing of 101-AZ and 102-AZ Sludges (Winkler 1993), which defines a strategy to retrieve, wash, and decant NCAW. Water is added to the DSSF prior to cesium ion exchange to prevent possible precipitation of solids on the resin beds. The NCAW is assumed to be concentrated to a sodium concentration of $5 \mathrm{M}$ before being fed to the ion exchange columns. The DSSF waste will be diluted to a sodium concentration of $7 \mathrm{M}$ before being fed to the ion exchange columns.

The DSSF waste is assumed to contain no suspended solids. 100 parts per million (ppm) of solids is assumed to be entrained in the NCAW supernate after decanting. $100 \%$ of this amount of solids is assumed to be removed by the pre-cesium ion exchange filter F-C3A. No solids are assumed to be generated in the CS-IX process, therefore the mass of solids removed by the post-cesium ion exchange filter is zero. 


\subsection{CESIUM LOADING}

For the NCAW material balance calculations, an average of 180 bed volumes of ion exchange feed are assumed to be processed through the columns between elutions. For the DSSF waste material balance calculations, an average of 129 bed volumes of ion exchange feed are assumed to be processed through the columns between elutions. The technical bases of the loading volume estimate is given in Appendix A.

The amount of potassium which will load onto the ion exchange column was based upon potassium equilibrium distribution data extrapolated from data developed by Pacific Northwest Laboratory (Kurath et a1. 1994).

\subsection{CESIUM ELUTION FROM RESIN}

$\mathrm{HNO}_{3}$ at a concentration of $0.5 \mathrm{M}$ and $40{ }^{\circ} \mathrm{C}$ is used for elution of the loaded resin. Greater than $99 \%$ of the initial mass of loaded cesium is assumed to be removed from the resin each elution with $10.0 \mathrm{gmole}^{+} / \mathrm{L} \mathrm{R}-\mathrm{F}$ resin.

The eluate passes through an acid recycle process where $70 \%$ of the acid is recovered and recycled for reuse in the elution process. (Orme 1994) The eluate is then neutralized before it is sent to interim storage prior to being processed at the HLW vitrification facility (see Section 4.2.8).

\subsection{RESIN REPLACEMENT}

The resin chemically and radiologically degrades. Therefore, the ion exchange resin in each column is replaced after it has been cycled five times. The assumption of five cycles per resin replacement is conservative. It was based on the cumulative resin exposure associated with processing NCAW. Chemical cycling tests, radiation tests, and tests with actual waste will allow better estimates to be made.

Currently, the storage and disposal methods for the ion exchange resin are not known. In the past, the cesium ion exchange materials at B Plant were eluted as much as practical. The materials were converted to the sodium form, then removed from the IX column. Finally, they were drummed, dewatered, and sent to burial as LLW.

\subsection{LOW LEVEL WASTE}

A $10 \mathrm{M}$ sodium concentration in the LLW vitrification facility feed stream is assumed. (Orme 1994) The LLW glass form is assumed to contain $20 \%$ (wt.) $\mathrm{Na}_{2} \mathrm{O}$, and have a density of $2.6 \mathrm{MT} / \mathrm{m}^{3}$. 
WHC-SD-WM-TI-638 REV 0

This page intentionally left blank. 


\subsection{RROCESS DESCRIPTION}

An overall process flow diagram is shown in Figure 4-1.

\subsection{RETRIEVE, SLUDGE WASH, DECANT, EVAPORATE, AND FILTER}

Waste is retrieved by pumping of supernates, and sluicing of solids. The solids are washed, allowed to settle, and the liquid supernate is decanted. Repeated wash, settle, decant cycles may be performed based on needs. Caustic washing solutions may be used to reduce solids volumes by leaching. Water, sodium hydroxide solution, and sodium nitrite solution were added to NCAW during the retrieval, sludge wash, and decent step (Winkler 1993). 97\% of the dissolved NCAW solids are removed with the supernate while only $0.4 \%$ of the suspended solids remain with the supernate. The NCAW supernate decants are expected to contain $100 \mathrm{ppm}$ of suspended solids. DSSF waste is diluted to a nominal $7 \mathrm{M}$ sodium concentration to prevent solids precipitation in the Cs-IX process.

The washed NCAW supernate solution is evaporated to a nominal sodium concentration of $5 \underline{M}$ to reduce tank storage space requirements and IX processing volumes. Evaporated water is recycled for further waste retrieval and sludge washing. The solutions are then cooled to about $25^{\circ} \mathrm{C}$.

The $7 \mathrm{M} \mathrm{Na}^{+}$, and the $5 \mathrm{M} \mathrm{Na}^{+}$solutions at $25{ }^{\circ} \mathrm{C}$ are passed through a filter to further reduce the amount of suspended solids before being fed to the CS-IX columns. $100 \%$ of the suspended solids are assumed removed by the pre-Cs-Ix filter. The DSSF is assumed to have no suspended solids for the purposes of a mass balance, however solids are expected and thus pre-Cs-Ix filtration is provided. 
WHC-SD-WM-TI-638 REV 0

This page intentionally left blank. 
RETRIEVAL / SLUOGE WASHING

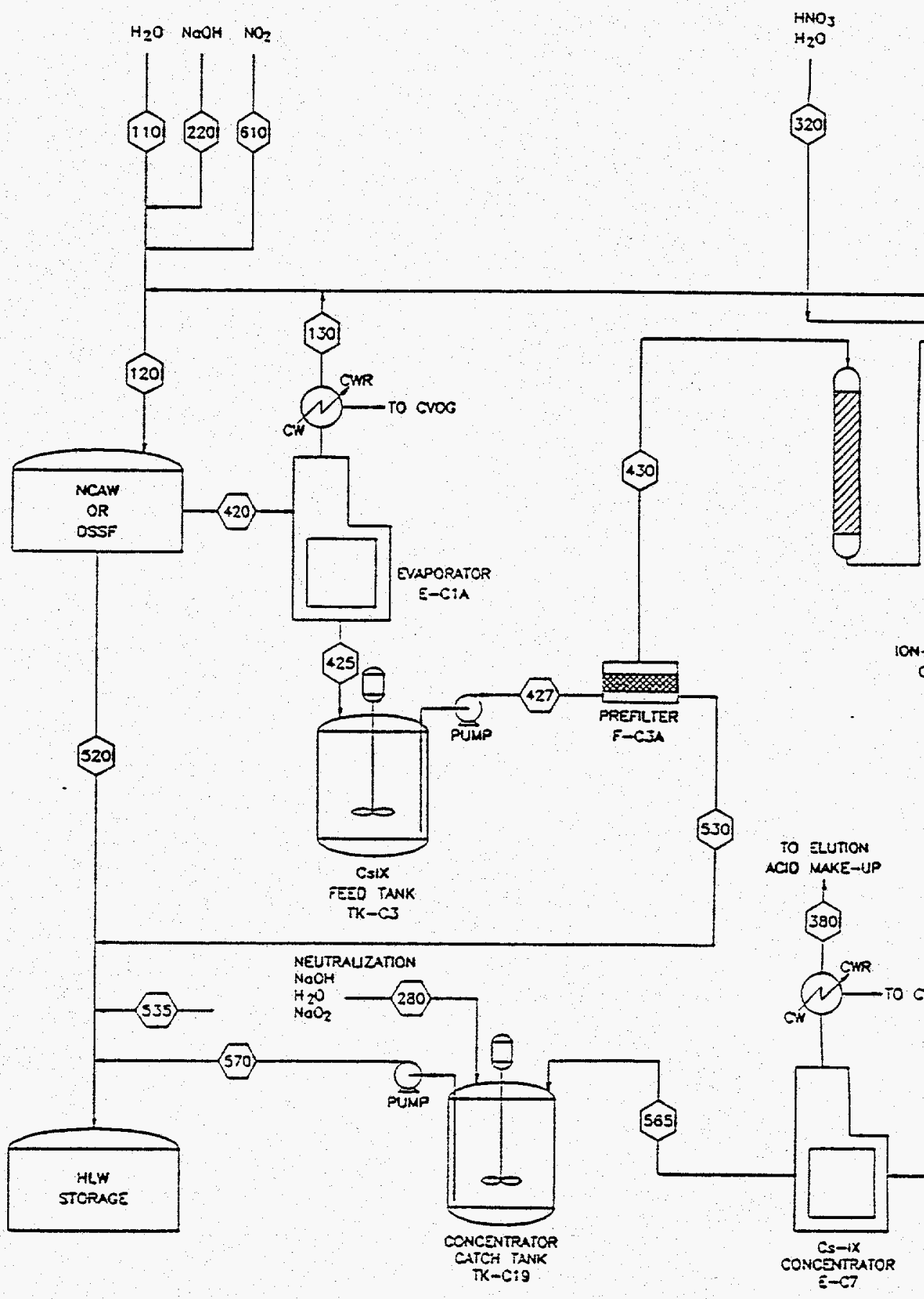


Figure 4-1. TWRS Cesium Ion Exchange Process Flow Diagram.

WATER

MASHES

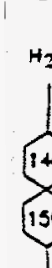

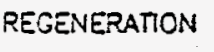

$\mathrm{NaOH}$

1

(231)

233
RESIN CHANGE-OUT

TRESH RESIN

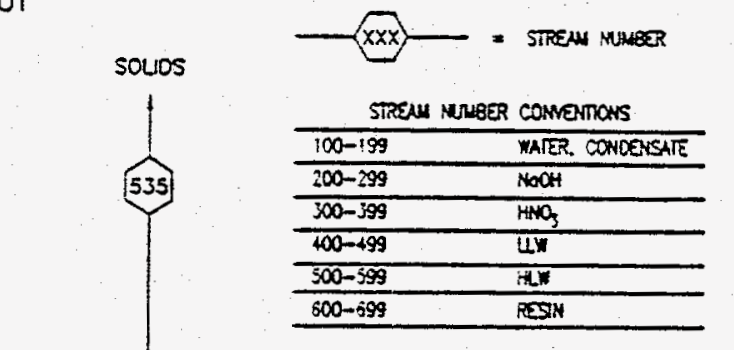

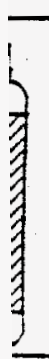

Dene

MNS

23

$i$

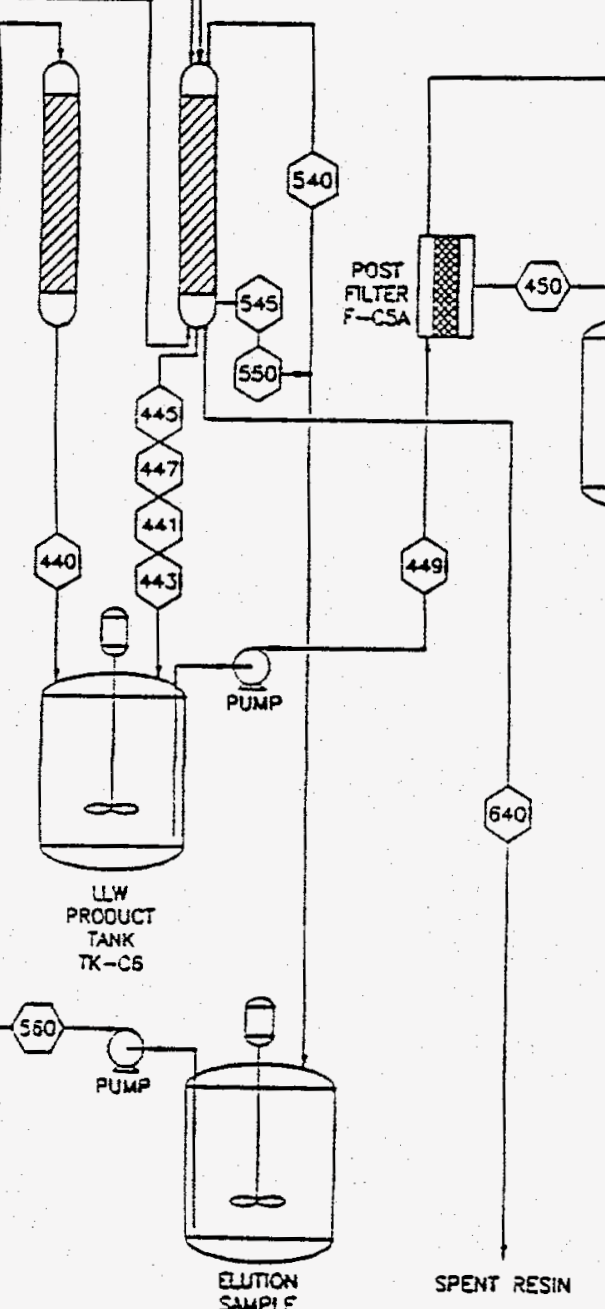

NOTE: REFER TO TAGLSS $12.1-12.7$ FOR NCAW MATERLL ENANCE OATA TABLES $12.3-12.14$ FOR DSSF MATERU BUWWE DATA EYAPORATOR

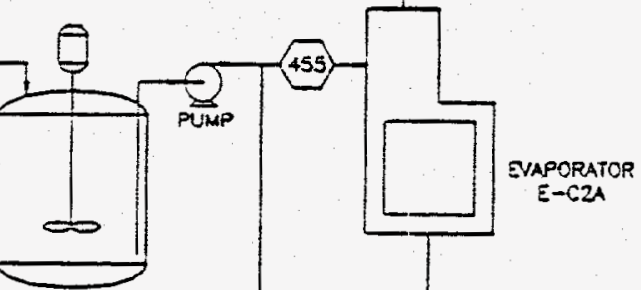

SWHPIE

ThNKK

SPENT RESIN

TANK

$\pi K-C g$

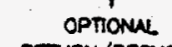

RETURN/RECYCLE

TO CSIX FEED
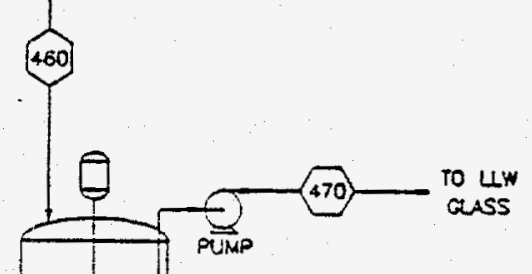

auss

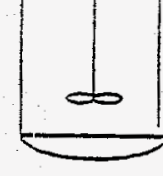

LWW CONCENTRATOR

CAICH TANK

$T K-\mathrm{C}: 2$

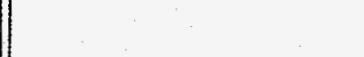

KNET/ HAN/ $/ 12-5-94 / 3$ 


\subsection{CESIUM ION EXCHANGE}

This ion exchange flowsheet is based on a flowrate of $108 \mathrm{~L} / \mathrm{min}$ downflow, through the ion exchange columns. Three ion exchange columns connected in series are onl ine at any time. Each column contains 2,000 L of R-F resin. 99.99\% of the entering cesium is removed by the resin from the NCAW (DF of about 8,490 ), and $99.75 \%$ of the entering cesium is removed by the resin from the DSSF (DF of about 400).

Sections 4.2.1 through 4.2 .8 provide a description of the ion exchange operation. Tables 4-1 and 4-2 summarize column operations for NCAW and DSSF Cs-IX feeds respectively.

Table 4-1. Summary of Column Operations per Cycle for Neutralized Current Acid Waste.

\begin{tabular}{|c|c|c|c|c|c|c|}
\hline $\begin{array}{l}\text { Stream } \\
\text { number }\end{array}$ & 430 & 140 & 320 & 150 & 231 & 233 \\
\hline Description & $\begin{array}{l}\text { Feed } \\
\text { at } 5 \mathrm{M} \mathrm{Na}\end{array}$ & Water Wash & $\begin{array}{c}\text { Elution } \\
\text { at } 0.5 \mathrm{M} \mathrm{HNO}_{3}\end{array}$ & Water Wash & $\begin{array}{c}\text { Regeneration } \# 1 \\
0.5 \mathrm{M} \mathrm{NaOH}\end{array}$ & $\begin{array}{c}\text { Regeneration } \# 2 \\
2.0 \mathrm{M} \mathrm{NaOH}\end{array}$ \\
\hline BV & 180 & 1.5 & 20 & 2 & 4 & 3 \\
\hline Flow direction & Down & Down & Up & Down & up & up \\
\hline $\begin{array}{l}\text { Flowrate } \\
\text { (L/min) }\end{array}$ & 108 & 200 & 100 & 200 & 100 & 100 \\
\hline $\begin{array}{c}\text { Temperature } \\
\left({ }^{\circ} \mathrm{C}\right)\end{array}$ & 25 & 25 & 40 & 25 & 25 & 25 \\
\hline $\begin{array}{l}\text { Volume } \\
\text { (L/cycle })\end{array}$ & 360,000 & 3,000 & 40,000 & 4,000 & 8,000 & 6,000 \\
\hline $\begin{array}{l}\text { Time } \\
(\min / c y c l e)\end{array}$ & 3,600 & 15 & 400 & 20 & 80 & 60 \\
\hline Mass $\mathrm{Na}^{\circ}$ (kgs) & 41,400 & -- & $\cdots$ & -- & 92 & 276 \\
\hline Mass $\mathrm{OH}^{-}$(kgs) & 13,770 & -- & -- & -- & 68 & 204 \\
\hline Mass $H^{+}$(kgs) & $\cdots$ & $\cdots$ & 20 & $\cdots$ & $\cdots$ & -- \\
\hline Mass $\mathrm{NO}_{3}^{-}$(kgs) & 29,239 & -- & 1,240 & -- & -- & -- \\
\hline Mass $\mathrm{H}_{2} \mathrm{O}$ (kgs) & 360,000 & 3,000 & 39,289 & 4,000 & 7,992 & 5,826 \\
\hline $\begin{array}{l}\text { Column effluent } \\
\text { stream number }\end{array}$ & 440 & 445 & 540 & $\begin{array}{l}550 \text { (HLW), } \\
447 \text { (LLW) }\end{array}$ & 441 & 443 \\
\hline
\end{tabular}


Table 4-2. Summary of Column Operations per Cycle for Double-Shell Slurry Feed.

\begin{tabular}{|c|c|c|c|c|c|c|}
\hline $\begin{array}{l}\text { Stream } \\
\text { number }\end{array}$ & 430 & 140 & 320 & 150 & 231 & 233 \\
\hline Description & $\begin{array}{l}\text { Feed } \\
\text { at } 7 \underline{\mathrm{M} ~ \mathrm{Na}^{+}}\end{array}$ & $\begin{array}{l}\text { Water } \\
\text { wash }\end{array}$ & $\begin{array}{c}\text { Elution } \\
\text { at } 0.5 \underline{\mathrm{M}} \mathrm{HNO}_{3}\end{array}$ & $\begin{array}{l}\text { Water } \\
\text { wash }\end{array}$ & $\begin{array}{c}\text { Regeneration \#1 } \\
0.5 \mathrm{M} \mathrm{NaOH}\end{array}$ & $\begin{array}{c}\text { Regeneration \#2 } \\
2.0 \mathrm{M} \mathrm{NaOH}\end{array}$ \\
\hline BV & 129 & 1.5 & 20 & 2 & 4 & 3 \\
\hline Flow direction & down & down & up & down & up & up \\
\hline $\begin{array}{l}\text { Flowrate } \\
(L / \min )\end{array}$ & 108 & 200 & 100 & 200 & 100 & 100 \\
\hline $\begin{array}{c}\text { Temperature } \\
\left({ }^{\circ} \mathrm{C}\right)\end{array}$ & 25 & 25 & 40 & 25 & 25 & 25 \\
\hline Volume (L/cycle) & 258,000 & 3,000 & 40,000 & 4,000 & 8,000 & 6,000 \\
\hline Time (min/cycle) & 2,580 & 15 & 400 & 20 & 80 & 60 \\
\hline Mass $\mathrm{Na}^{\circ}$ (kgs) & 41,538 & -- & -- & -- & 92 & 276 \\
\hline Mass $\mathrm{OH}^{-}$(kgs) & 15,554 & $\because$ & - & -- & 68 & 204 \\
\hline Mass $H^{*}$ (kgs) & $\cdots$ & - & 20 & -- & $\cdots$ & $\cdots$ \\
\hline Mass $\mathrm{NO}_{3}^{-}$(kgs) & 34,071 & -- & 1,240 & $\cdots$ & $\cdots$ & -- \\
\hline Mass $\mathrm{H}_{2} \mathrm{O}$ (kgs) & 238,890 & 3,000 & 39.289 & 4,000 & 7,992 & 5,827 \\
\hline $\begin{array}{l}\text { Column effluent } \\
\text { stream number }\end{array}$ & 440 & 445 & 540 & $\begin{array}{l}550 \text { (HLW), } \\
447 \text { (LLW) }\end{array}$ & 441 & 443 \\
\hline
\end{tabular}

\subsubsection{Column Loading}

The three online columns are loaded at about $3 \mathrm{BV} / \mathrm{h}(108 \mathrm{~L} / \mathrm{min}$, or $29 \mathrm{gal} / \mathrm{min}$ ) downflow (Stream number 430). The corresponding column effluent stream is Stream number 440 . An average of 180 bed volumes $(360,000 \mathrm{~L}$ at 2,000 L per column) of NCAW CS-IX feed solution is processed before the lead column must be taken off line for elution (129 bed volumes, 258,000 L, for the DSSF). These are averages because the volume will vary with resin condition. On start-up all resin will be fresh and unloaded, therefore up to 220 $\mathrm{BV} / \mathrm{cycle}$ may be achieved. In normal cyclical operation, an average of 180 BVs/cycle is expected because all resin beds are expected to be loaded to some extent. As the resin is degraded by chemical and radiolitic action the processable volume may fall below the predicted average. The high concentration of potassium in the DSSF CS-IX feed reduces the volume of waste processed and the amount of cesium loaded on the resin at the breakthrough point. At the breakthrough point approximately $13,000 \mathrm{mg} \mathrm{Cs} / \mathrm{L}$ resin are loaded onto the lead IX column for NCAW or $1,600 \mathrm{mg} \mathrm{Cs} / \mathrm{L}$ resin for DSSF. Cs-IX column effluent is collected in tanks, sampled and analyzed for product approval.

Columns operate in a "carousel" fashion, i.e., when the lead column is taken off 1 ine at breakthrough point the second column is valved so that it becomes the lead column, the previously third column becomes the second column and a freshly eluted/regenerated column becomes the third or last column. Section 5.2.2 contains a more detailed description of a "carousel" system. 


\subsubsection{Post Load Wash}

At the breakthrough point, which is determined with the aid of online gamma monitors, the loaded lead column is taken off line, washed with a volume of $3,000 \mathrm{~L}$ of water (1.5 BV) (Stream number 140) or caustic solution. The wash prevents precipitation of solids in the column which could form as the solution $\mathrm{pH}$ drops due to either dilution or addition of acid. The wash flow rate will be $100 \mathrm{~L} / \mathrm{min}(3 \mathrm{BV} / \mathrm{h})$, downflow. After passing through the column, this volume will be combined with the HLW stream. The corresponding column effluent stream is Stream number 545 .

In place of this water wash, an optional water back-wash can be performed. The goal of the backwash is to remove fines which could increase the pressure drop across the bed, and redistribute the resin bed to prevent packing and channelling. The back-wash (upflow) would be with $6,000 \mathrm{~L}$ of water ( 3 BVs) at a rate sufficient to expand the bed volume by $50 \%$ (approximateiy $300 \mathrm{~L} / \mathrm{min}$ ).

\subsubsection{Elution}

After washing, the off-line column is eluted with $40,000 \mathrm{~L}$ (20 BV) (Stream number 320 ) of $0.5 \mathrm{M} \mathrm{HNO}_{3}$ at a rate of $100 \mathrm{~L} / \mathrm{min}(3 \mathrm{BV} / \mathrm{h})$, upflow. The corresponding column effluent stream is Stream number 540. Greater than $99 \%$ of the loaded cesium is removed from the loaded resin bed with $10.0 \mathrm{gmole} \mathrm{H}^{+} / \mathrm{L}$ $\mathrm{R}-\mathrm{F}$ resin. The estimated total number of elutions that will be required to process a 11 NCAW and DSSF waste is calculated as follows:

Number of elutions needed to process all NCAW waste:

$$
\frac{4.50 \times 10^{6} \mathrm{~L} \text { of } 5.0 \underline{\mathrm{M} \mathrm{Na}}+}{\text { NCAW }} \mid \frac{\text { elution }}{360,000 \mathrm{~L} \text { of } 5.0 \underline{\mathrm{M} \mathrm{Na}}{ }^{+}}=13 \frac{\text { elutions }}{\text { NCAW }}
$$

Number of elutions needed to process al1 DSSF waste:

$$
\frac{7.02 \times 10^{7} \mathrm{Lof} 7.0 \mathrm{M} \mathrm{Na}^{+}}{\text {DSSF }} \mid \frac{\text { elution }}{258,000 \mathrm{~L} \text { of } 7.0 \mathrm{M} \mathrm{Na}^{+}}=272 \frac{\text { elutions }}{\text { DSSF }}
$$

\subsubsection{Water Wash (Post-Elution)}

The eluted, off-line column will be washed with 4,000 L of water (2 BVs) (Stream number 150 ) to remove residual acid and cesium, at a rate of $100 \mathrm{~L} / \mathrm{min}$ $(3 \mathrm{BV} / \mathrm{h})$, downflow. After passing through the column, the initial 2,000 L of this wash will be combined with the HLW stream (column effluent Stream number 550), the later collected $2,000 \mathrm{~L}$ will be combined with the LLW stream (column effluent Stream number 447). 


\subsubsection{Regeneration}

Sodium regeneration is done in two steps, first with a weaker sodium hydroxide solution, then with a more concentrated solution. The two step approach is assumed to conserve sodium hydroxide by providing more time for interstitial mixing, and to be gentler on the resin by slowing expansion.

4.2.5.1 First Caustic Regeneration. The eluted, washed, off-1 ine column will be regenerated with $8,000 \mathrm{~L}$ (4 BV) (Stream number 231) of $0.5 \mathrm{M} \mathrm{NaOH}$ solution, at a rate of $100 \mathrm{~L} / \mathrm{min}(3 \mathrm{BV} / \mathrm{h})$, in an upflow direction. After passing through the column, this volume will be combined with the LLW stream. The corresponding column effluent stream is Stream number 441.

4.2.5.2 Second Caustic Regeneration. After the first caustic regeneration stage, the off-line column enters a second regeneration stage where it is contacted with $6,000 \mathrm{~L}$ (3 BV) (Stream number 233) of $2.0 \mathrm{M} \mathrm{NaOH}$ solution, at a rate of $100 \mathrm{~L} / \mathrm{min}(3 \mathrm{BV} / \mathrm{h})$, in an upflow direction. After passing through the column, this volume will be combined with the LLW stream. The corresponding column effluent stream is Stream number 443.

The theoretical sodium ion demand for regeneration of the resin is about 1.57 gmole $\mathrm{Na}^{+} / \mathrm{L}$ of $\mathrm{R}-\mathrm{F}$ resin per regeneration. For this flowsheet, approximately 4 times that amount is provided to the resin for regeneration by regeneration steps 1 and 2 . Since there is a lack of regeneration data for the $R-F$ resin, this number could be over-conservative and could represent an opportunity for optimization in the future.

\subsubsection{Resin Change out}

After 5 loading and elution cycles, of a particular column, the resin is removed from the column and new resin placed in the column. Approximately $8,000 \mathrm{~L}$ of wet $\mathrm{Na}^{+}$form resin will be sent to resin disposal during the processing of all the NCAW, ( 4 bed volumes of resin at 2,000 L per bed volume).

Before change out, the resin will be eluted and regenerated to convert it to the sodium form for storage. New resin will be washed upflow with approximately 5 bed volumes of water at a rate fast enough to fluidize the resin bed. This step will remove resin fines and other possible contamination. The new resin bed will then be washed with 2 bed volumes of $2 \mathrm{M}$ sodium hydroxide solution to convert the resin as completely as possible to the sodium form before use. The wash operations for the new resin will be carried out in a separate, uncontaminated vessel. All wastes collected from these washes will be chemical nonradioactive wastes. 


\subsubsection{Resin Preparation for Storage and Disposal}

The $\mathrm{Na}^{+}$form resin will be dewatered for storage/disposal to a density approximately equivalent to that of air dry $\mathrm{Na}^{+}$form resin $(461 \mathrm{~g} / 1 \mathrm{iter}$ ). A total of about 3.7 MT of spent, dewatered, $\mathrm{Na}^{+}$form, $\mathrm{R}-\mathrm{F}$ resin will be generated from the processing of the NCAW. About 51.6 MT of spent, dewatered, spent resin will be generated from the processing of DSSF waste.

New resin will be purchased in the $K^{+}$form. Assuming that the resin has a reversible volume increase of $1 \%$ when converted from the $\mathrm{K}^{+}$to the $\mathrm{Na}^{+}$form, about $7,920 \mathrm{~L}$ of $\mathrm{K}^{+}$form, $\mathrm{R}-\mathrm{F}$ resin will need to be purchased to process the NCAW and 27,720 L for DSSF. At a density of $893 \mathrm{~g}$ moist $\mathrm{K}^{+}$form resin per liter this amounts to about 7.1 MT of $\mathrm{K}^{+}$form, R-F resin for processing NCAW and 89.8 MT for DSSF.

NOTE: $\quad$ The concept of purchasing acid washed R-F resin in the H+form should be evaluated. Purchasing acid washed $R-F$ resin decreases the amount of fines remaining on the resin. Currently only a small portion of 1 batch of $R-F$ resin has been obtained in the acid washed $(H+)$ form. No data is currently available to show whether purchasing the R-F resin in the $\mathrm{H}+$ form increases or decreases the time the resin may be stored without noticeable degradation.

The storage requirements and method for the spent resin have not been defined. The final disposal method has not been defined. In the past, the cesium ion exchange materials at B Plant were eluted as much as practical. The materials were converted to the sodium form, then removed from the IX system. Finally, they were dewatered, drummed, and sent to burial as LLW.

\subsubsection{Elution Acid Recovery}

The eluate from the ion exchange (Stream number 560 ) is concentrated to reduce the eluate storage volume, to reduce the mass of chemicals fed to HLW, and to reduce the amount of make-up $\mathrm{HNO}_{3}$ and water required for elution. About $98 \%$ of the volume and $70 \%$ of the acid in the eluate is recycled for use in subsequent elutions.

The Cs-IX eluate in tank TK-CI5 is concentrated to a bottoms nitrate concentration of about $7 \underline{M}$ nitrate in the CS-IX concentrator (E-C7 in Figure 41). The acidic condensate from the concentrator (Stream number 380 in Figure 4-1) is sent to the elution acid make-up tanks (not shown in Figure 41) where acidic solutions are made up for subsequent column elutions. In tank TK-C19 the acidic concentrator bottoms are neutralized with sodium hydroxide solution, and sodium nitrite solution is added to bring the concentrations to $0.3 \mathrm{M} \mathrm{OH}^{-}$and $0.9 \mathrm{NO}_{2}^{-}$to meet tank farm composition specifications for storage in carbon steel tanks. 
WHC-SD-WM-TI-638 REV 0

This page intentionally left blank. 


\subsection{PROCESS TECHNOLOGY}

\subsection{CHEMISTRY}

A theoretical background for understanding cesium ion exchange equilibrium, kinetics, as well as column scale-up considerations was given a thorough treatment in a recent publication (Kurath et a1. 1994). The report summarizes much of the relevant data necessary for the design of an ion exchange process for removal of cesium from Hanford Site tank waste supernates and sludge wash waters. The document focuses on work associated with CS-100 and R-F resins. It contains information about expected feed compositions, process performance criteria, equilibrium behavior, kinetic behavior, and chemical and radiolytic stability of the resins. A preliminary engineering analysis of the data is included as well as loading and elution modeling results.

Ion exchange feed solutions are high alkaline, high salt wastes. A pH of 10 to 12 is generally effective for loading R-F resin.

The CS-IX process is based on the development and testing work done during the last decade with CS-100 resin and more recently with R-F resin (Bray 1984, Bray 1992, Bray 1993, Kurath et al. 1994). The R-F resin has a high selectivity for cesium. The resin's general use is with alkaline radioactive waste solutions. The general functional groups of the resin are phenolic. The particle mesh size is 25 to $>70$ mesh, U.S. standard sieves. The density of the dried sodium form resin is about $461 \mathrm{~g} / \mathrm{L}$.

During the early 1980's, PNL evaluated precipitation and ion exchange as methods to remove cesium from West Valley waste supernate. CS-100 (an organic resin) and IONSIV ${ }^{*}$ IE-95 (an inorganic ion exchanger) were identified as viable candidates for cesium removal based on tests with simulants of West Valley Supernate. The results are reported in the Bray 1984 reference. The testing showed that removal of cesium by Duolite CS-100 is dependent on resin particle size, temperature, and $\mathrm{pH}$. The column tests showed that higher cesium loadings were achieved at smaller resin size classifications. The cesium loading capacity of CS-100 improves with higher $\mathrm{pH}$, and is best at a pH $>13$.

A technical study was conducted in 1986 with the goal of finding the best available ion exchange material for the removal of cesium from NCAW. After a literature search, seven most promising exchangers (Duolite CS-100, Duolite ARC 9359, Duolite ES 286, Durasi ${ }^{\star *} 10$, Durasil 210, Vitrokele 55, and Zeolon ${ }^{* * *}$ 900) were chosen for batch contact tests with an NCAW simulant. The best cesium distribution coefficients were obtained for Zeolon 900, and Duolite ARC 9359, followed by Duolite CS-100. CS-100 was

\footnotetext{
"IONSIV is a trademark of UOP.

**Durasil is a trademark of Duratek Corporation.

${ }^{* * *}$ Zeolon is a trademark of the Norton Company.
} 
chosen for further study because neither Zeolon 900 or Duolite ARC 9359 were currently being manufactured at that time (Gibson and Landeene 1987, Gallagher 1986). Another advantage of the CS-100 resin is that it is resistant to acids, bases and radiation.

With the development of $R-F$ resin by researchers at Savannah River, the resin was tested with Savannah River Site waste. The testing showed that "The cesium loading capacity of R-F resin is ten times that of any similar available resin." It was also determined that elution with about 10 bed volumes of $1 \mathrm{M}$ formic acid removed $99 \%$ of the sorbed cesium (Bibler et al. 1990). The resin testing report also concluded that the resin could probably be used to remove cesium from wastes other than Savannah River wastes. The improved characteristics of the resin made it advisable to consider it as a candidate for use for cesium removal from the Hanford wastes.

In 1990 Bray also issued a report for testing of the R-F resin. The resin was used to remove cesium from simulated SRS waste. It was concluded that a cesium decontamination factor for the feed of $>10^{4}$ is achievable. It was also concluded that the loss in capacity of R-F resin after seven loading/ elution cycles was $5 \%$ to $20 \%$.

An ion exchange process which removes cesium from the supernate associated with neutralized PUREX high-level waste at the West Valley Demonstration Project was developed at Pacific Northwest Laboratory using a combination of laboratory testing with waste simulants and mathematical modeling. A study compared the performance of the actual process operation with those predicted by the laboratory studies with waste simulants and mathematical models (Kurath, et. al. 1990).

Breakthrough curves from actual operations were nearly identical as those predicted from laboratory work. Cesium distribution coefficients calculated from the first four actual operation runs averaged 35, which agreed well with the laboratory predicted value of 36 . The system consistently achieved cesium DFs of 10,000 to 100,000 .

The usefulness of laboratory development of the ion exchange process with waste simulants was demonstrated by the correlation between the laboratory data and the process scale results.

PNL was requested to study several ion exchange materials for the removal of cesium from Hanford tank wastes. PNL obtained equilibrium data for three ion exchange materials. The materials were IONSIV IE-96 (a zeolite produced by UOP), CS-100 (an organic resin produced by Rohm and Haas), and R-F resin. The results of the testing were issued in Bray 1992.

The testing showed that the ion exchange capacity of IONSIV IE-96 and CS-100 increases significantly as the loading temperature is lowered from $40{ }^{\circ} \mathrm{C}$. However, the temperature effect on the $R-F$ resin is not as profound. It also showed that the initial volume of feed that can be processed using R-F resin decreases by approximately $10 \%$ with a $3 X$ feed dilution, and by $>30 \%$ with CS-100. 
Based on equilibrium behavior, the following major trends pertinent to the use of $R-F$ resin have been observed. The conditions that favor the highest selectivity for cesium are low temperature, concentrated feeds and low potassium concentration relative to cesium concentration. Efforts to model resin loading and elution are ongoing at PNL. Some preliminary modeling work is reported in Kurath et al. 1994.

In the absence of channeling, $\mathrm{R}-\mathrm{F}$ resin elutes well with $\mathrm{HNO}_{3}$ concentrations of 0.5 to $1.0 \mathrm{M}$ at a temperature of $40^{\circ} \mathrm{C}$. (Channeling is an unresolved issue associated with clumping of the R-F resin.) R-F resin does not elute well at temperatures below $40^{\circ} \mathrm{C}$. Chemical usage can be reduced by eluting at low liquid flow rates. $\mathrm{HNO}_{3}$ is compatible with the existing waste and is easier to recover and recycle. $\mathrm{HNO}_{3}$ eluant of $0.5 \mathrm{M}$ concentration is selected for this flowsheet. A maximum $\mathrm{HNO}_{3}$ concentration of $1.0 \mathrm{M}$ is recommended for elution. Elution testing has not shown safety problems at this concentration. (See Section 9.0 and Appendix A for information about exothermic reactions between organic resins and $\mathrm{HNO}_{3}$. )

While this flowsheet uses $\mathrm{HNO}_{3}$ for elution, the use of formic acid $(\mathrm{HCOOH})$ for elution merits further consideration. $\mathrm{HCOOH}$ can be used at higher concentrations than $\mathrm{HNO}_{3}$. The use of $\mathrm{HCOOH}$ minimizes safety concerns associated with resin/concentrated $\mathrm{HNO}_{3}$ reactivity.

The regeneration solutions are dilute sodium hydroxide solutions. The sodium hydroxide solutions displace the water flushing solution restoring the column to high $\mathrm{pH}$ conditions, and convert the resin to the sodium form.

\subsection{ENGINEERING}

\subsubsection{One-Pass System}

A multi-pass system is defined as repumping the once treated cesium column effluent through the the same or another column system for further cesium removal. The choice of using a one pass process as opposed to a multipass system for this flowsheet was based on the following advantages:

- A one-pass system is theoretically simpler to operate and maintain than a multi-pass system.

- A one-pass system theoretically requires less equipment and therefore has a lower capital cost than a multi-pass system.

Further development work is needed to evaluate the feasibility of a one-pass ion exchange system which uses $R-F$ resin.

\subsubsection{Column Configuration}

A carousel configuration operates with one or more columns online, in series in a "train of columns". processing feed until a "breakthrough point" is reached while the other column is off line being eluted and regenerated. This process uses a "train" of three columns in series to process waste. The 
breakthrough point is defined as the point at which a predetermined maximum concentration of cesium in the ion exchange product stream (the effluent stream of the last IX column) is reached. This concentration is determined based on cesium removal requirements e.g. the requirement to produce a class $A$ waste form.. At the breakthrough point the lead column which is loaded with cesium to a greater extent than the two subsequent columns, is taken off line for cesium elution. The breakthrough point as defined in this document can be considered the "control point" for column loading.

The column which was previously off line; which is now fully eluted and regenerated, is coupled to the column train in the last position to make a "new" three column train. The "new" train consists of the column which previously held the second position in the lead position, the column which previously held the third position in the second position, and the freshly eluted and regenerated column in the third or last position. The column train is then put back online to process more feed while the off-line, loaded column is being eluted and regenerated. The columns of the carousel are stationary, streams are routed by valving changes. Figure 5-1 illustrates the operation of a four column "carousel".

A carousel configuration is more efficient in minimizing the amount of chemical used for elution because it allows columns to be more fully loaded with cesium than a single column. To a point, the more columns there are in the carousel, the less chemicals are needed for elution on a per mass of cesium basis. The point at which adding more columns to the carousel does not significantly reduce the amount of elution chemicals is determined by the kinetics of the resin and the flowrate of feed used. The disadvantage of increasing the number of columns in a carousel system is that, system capital cost, and operating, and maintenance complexity increase as the number of columns increases.

A three column online train with a one hour retention time has been selected for use in this flowsheet because based on data with DSSF simulants and fresh (previously unused or uncycled) R-F resin. (Kurath et a1.) This system is estimated to be a preliminary optimum of elution chemical usage, capital costs, and operating and maintenance complexity. More rigorous efforts are needed to better optimized total number of columns based on these parameters. 
Figure 5-1. Operation of a Four Column "Carousel" System.
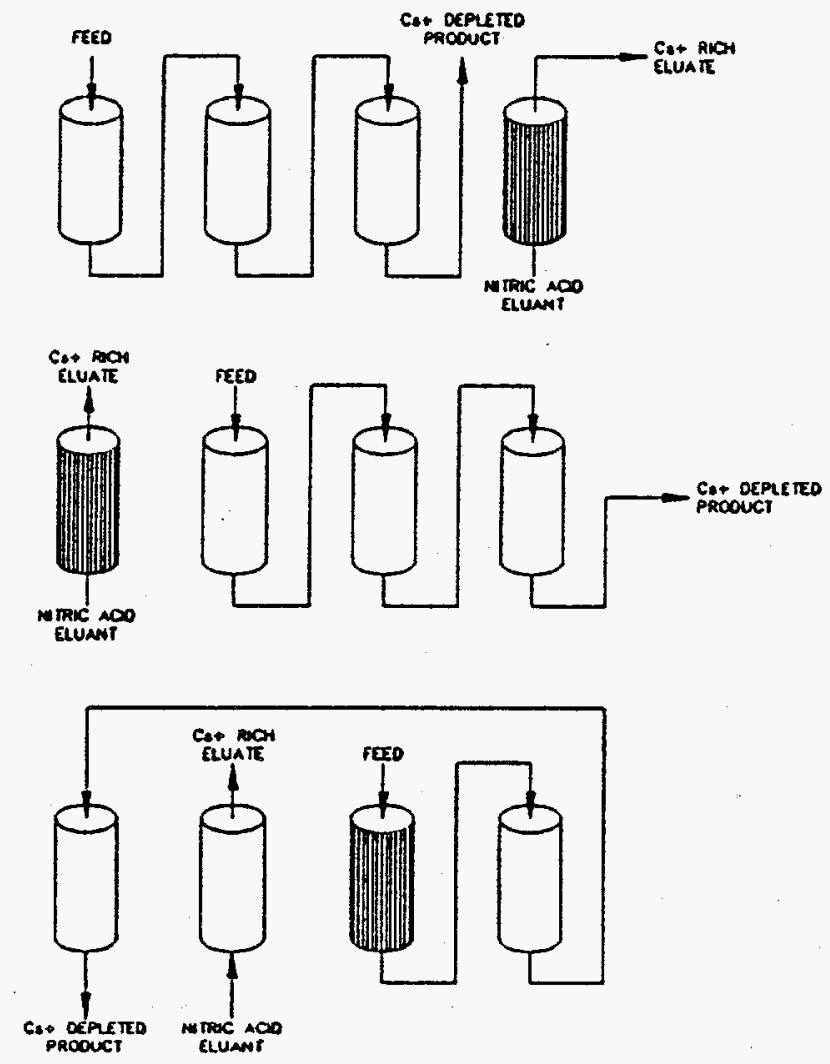

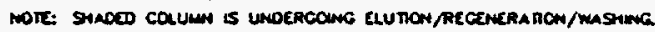

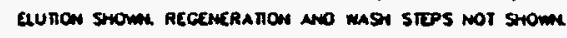


WHC-SD-WM-TI-638 REV 0

This page intentionally left blank.

$5-6$ 


\subsection{PROCESS CONTROL}

\subsection{GENERAL}

The ion exchange system requires close monitoring to achieve the required separation. Measurable valve leakage may preclude achieving the required separation. Leakage of less than $36 \mathrm{~L}$ of NCAW IX feed in a batch of $360,000 \mathrm{~L}$ causes the low level vitrification feed specifications to be exceeded.

The proposed ion exchange system is set up as a carousel system. A carousel system consists of columns set up with interconnecting piping and valves to allow each column to be valved in as the lead column in the series of ion exchange columns. The valve controls are electrically interconnected to allow a single switch to activate all valves required to move from one phase of the process cycle to the next. The operation is automated and controlled from a centralized control system. The system reduces changeover time which reduces process impacts and safety concerns related to stagnant columns.

Flow control, pressure sensors, gamma monitors for cesium, column vents, rupture disks, feed transuranic (TRU) monitors, and safety interlocks are required for the ion exchange system.

\subsection{OUTLET STREAM MONITORING}

Online monitoring of the outlet stream from each of the ion exchange columns is required. The monitors need to be tied to equipment set to divert the stream for recycle based upon radiation readings for the outlet stream.

The proposed system has collection tanks for the outlet stream. Those tanks would allow the outlet stream to be sampled before it is sent to interim storage or the glass plant.

\subsection{VALVE FAILURE MODE}

The failure mode for the process stream valves should not allow the process stream flow to go to LLW. This failure mode prevents significant contamination of the downstream LLW equipment. It also prevents contamination of the solution which has been processed to the point where it is above the required limits for feed to the LLW glass plant:

The failure mode for the cooling water valves for the ion exchange columns should be fail open. This prevents heat up of a loaded ion exchange column which could result in resin degradation. 


\subsection{TEMPERATURE CONTROL}

The ion exchange solution temperature is monitored at 2 or 3 selected locations in the column, as well as entering and exiting the column. Normally, the flow of process solutions through the column maintains the column at the desired temperature. However, if the flow of process solution is stopped, the temperature will slowly rise. Therefore, cooling water must also be available for back-up cooling of the ion exchange columns. The water should be connected so that it flows through the ion exchange columns in direct contact with the ion exchange material. An external chiller should be used to allow the cooling water to be recycled while maintaining the temperature below a predetermined safety setpoint. (The setpoint will be determined by resin safety testing, but will probably be approximately $80^{\circ} \mathrm{C}$. The $80^{\circ} \mathrm{C}$ temperature is based upon the operating temperature range suggested for CS-100 in the CS-100 technical data sheet.) The flow of cooling water to the column should start automatically if the temperature in the column reaches a predetermined setpoint. The cooling water flow rate is based on the temperature of the resin in the column to maintain the ion exchange material below a predetermined safe temperature limit.

The cooling water should contain some sodium hydroxide to prevent precipitation of aluminum containing compounds.

\subsection{CONTROL OF NITRIC ACID TO THE COLUMNS}

Instrumentation and interlocks are required to prevent $\mathrm{HNO}_{3}$ of concentrations greater than $1 M$ from contacting the organic resin in the column. See section 9 for a discussion of this potential safety hazard. 


\section{- 7.0 OFF-STANDARD CONDITIONS}

Off-standard conditions which affect safety are described in Section 9 with the other safety information.

\subsection{NITRIC ACID CONCENTRATION}

The $\mathrm{HNO}_{3}$ concentration of the eluant must meet specifications. If the concentration of the $\mathrm{HNO}_{3}$ is much above 1 molar, the resin may degrade significantiy due to acid oxidation. Research findings show that the R-F resin dissolves in $3 \mathrm{M} \mathrm{HNO}_{3}$. Testing needs to be performed to determine how $\mathrm{R}-\mathrm{F}$ resin reacts to $\mathrm{HNO}_{3}$ concentrations between 1 and $3 \mathrm{M}$. Appropriate instrumentation and interlocks are needed to prevent contact of concentrated $\mathrm{HNO}_{3}$ and the organic resin. The instrumentation and interlocks should prevent nitric acid concentrations greater than 1 M from flowing to the ion exchange columns. See Section 9.0 for a discussion of the safety aspects of concentrated $\mathrm{HNO}_{3}$ contacting the resin.

\subsection{LOSS OF FLOW TO A PARTIALLY OR FULLY LOADED COLUMN}

Loss of flow to a partialiy or fully loaded ion exchange column prevents dissipation of ${ }^{137} \mathrm{Cs}$ decay heat generated within the ion exchange column. The maximum decay heat load (a column fully loaded with NCAW waste) is $5.96 \times 10^{3}$ watts. This decay heat can heat the column to the temperature where the resin rapidly degrades. Normally, the flow of process solutions through the column maintains the column at the desired temperature. However, if the flow of process solution is stopped, the temperature will slowly rise. Therefore, cooling water must also be available for back-up cooling of the ion exchange columns. The water should be connected so that it flows through the ion exchange columns in direct contact with the ion exchange material. An external chiller should be used to allow the cooling water to be recycled while maintaining the temperature below a predetermined safety setpoint. setpoint will be determined by resin safety testing, but will probably be approximately $80^{\circ} \mathrm{C}$. The $80^{\circ} \mathrm{C}$ temperature is based upon the operating temperature range suggested for CS-100 in the CS-100 technical data sheet.) The flow of cooling water to the column should start automatically if the temperature in the column reaches a predetermined setpoint. The control point will be dictated by the results of testing associated with safety concerns about the degradation of the resin.

The cooling water should contain some sodium hydroxide to prevent precipitation of aluminum containing compounds.

The concept of draining the column of waste feed just prior to the start of cooling water should be evaluated. Draining the column will minimize the amount of cesium which will end up in the recirculated cooling water. 


\subsection{VALVE LEAKS}

Valve leakage can be a significant problem. If a valve leaks radioactive solution into a column that is being eluted or regenerated, it will result in failure of the system to meet product specifications. The contaminated solution will have to be recycled back through the ion exchange system after the valve is repaired or replaced.

An engineered system is required to detect and identify leaking valves. This includes installation of appropriate instrumentation on the valves and piping.

\subsection{PUMP FAILURE}

When an ion exchange feed pump fails, the ion exchange column should be drained or flushed (see the next paragraph for discussion of draining), and cooling water flow should be started when the temperature reaches predetermined safety point.

The concept of draining or flushing the column of waste feed just prior to the start of cooling water should be evaluated. Draining the column will minimize the amount of cesium which will end up in the recirculated cooling water. 


\subsection{EQUIPMENT DESCRIPTION}

\subsection{EQUIPMENT SIZES}

Vessel size is dictated by the batch sizes required for chemical makeup. The process throughput is set at approximately $108 \mathrm{~L} / \mathrm{min}$ ( 3 bed volumes per hour). The equipment list for the ion exchange process is shown in Table 8-1. The vessel sizes are based on the material balance.

\subsubsection{Resin Bed Size}

The resin bed is sized for a specific loading retention time required to efficiently achieve a desired cesium separation. Since the resin will load in the sodium or expanded form the design dimensions are based on the sodium form of the resin.

Resin bed aspect ratios (L/DS) of 2 are chosen for this design, other L/Ds would be acceptable. The kinetics of both the CS-100 and the R-F resin with both NCAW and DSSF waste have been shown to be controlled primarily by diffusion in the particle phase (as opposed to film diffusion limited). This means that the $L / D$ of the resin bed has no effect on resin kinetics. Resin bed L/Ds should thus be designed based on an optimization of other mechanical factors such as minimization of pressure drop, minimization of channelling, facilitation of column cooling, minimization of radiation and heat build-up, minimization of resin exposure to radiation, minimization of mass of potentially reactive chemicals, optimization of facility space, and minimization of construction costs.

A "rule of thumb" developed by Helfferich et. a1. (1992) states that columns should have bed aspect ratios of between 2 and 7 . For 7 arge columns aspect ratios as low as 1 may be used, however, columns with aspect ratios of less than one tend to give poor performance. In low aspect ratio beds, it is difficult to distribute the feed evenly over the area of the bed. The feed will tend to channel more easily, especially down the middle of the column, resulting in an under-utilized bed. As bed aspect ratio increases so does pressure drop.

The individual resin bed size is $2,000 \mathrm{~L}$ with 3 columns in series to give a total online volume of $6,000 \mathrm{~L}$. Based upon the assumptions previously stated, the column diameter is $1.08 \mathrm{~m}(3.5 \mathrm{ft})$ and the bed depth is $2.13 \mathrm{~m}$ $(7 \mathrm{ft})$. These equipment dimensions were used as a basis for the material balance calculations. 
Table 8-1. Cesium Ion Exchange Equipment List.

\begin{tabular}{|c|c|c|c|}
\hline Equipment name & Equipment ID & Capacity & Process control \\
\hline Evaporator Feed Sample Tank & TBD & $200,000 \mathrm{~L}$ & TBD \\
\hline Evaporator Feed Tank & TBD & $60,000 \mathrm{~L}$ & TBD \\
\hline Evaporator & E-C1A & $100,000 \mathrm{~L}$ & TBD \\
\hline CsIX Feed Cooler & TBD & TBD & TBD \\
\hline Csix Feed Tank & TK-C3 & $60,000 \mathrm{~L}$ & TBD \\
\hline Pre Csix filter & $F-C 3 A$ & $108 \mathrm{~L} / \mathrm{min}$ & TBD \\
\hline Csix Columns (4) & $c-c 3,5,7,9$ & $3,000 \mathrm{~L}$ each & TBD \\
\hline LLW Product Tank & TK-C6 & $60,000 \mathrm{~L}$ & TBD \\
\hline Post CsIX Filter & $F-C 5 A$ & $108 \mathrm{~L} / \mathrm{min}$ & TBD \\
\hline LLW Sample Tank & TK-C9 & $60,000 \mathrm{~L}$ & TBD \\
\hline LLW Evaporator & $E-C 2 A$ & $100,000 \mathrm{~L}$ & TBD \\
\hline LLW Concentrator Catch Tank & $T K-C 12$ & $60,000 \mathrm{~L}$ & TBD \\
\hline Elution Sample Tank & TK-C15 & $60,000 \mathrm{~L}$ & TBD \\
\hline Eluate Concentrator & $E-C 7$ & $60,000 \mathrm{~L}$ & TBD \\
\hline Eluate Concentrator Catch Tank & TK-C19 & $30,000 \mathrm{~L}$ & TBD \\
\hline Neutralization Batch Tank & TBD & $20,000 \mathrm{~L}$ & TBD \\
\hline Eluate Concentrator Overheads Tank & TBD & $60,000 \mathrm{~L}$ & TBD \\
\hline Elution Acid Make-up Tank & TBD & $50,000 \mathrm{~L}$ & TBD \\
\hline $\mathrm{HNO}_{3}$ Storage Tank & TBD & $40,000 \mathrm{~L}$ & TBD \\
\hline Water Storage Tank & TBD & $40,000 \mathrm{~L}$ & TBD \\
\hline Bulk NaOH Tank & TBD & $40,000 \mathrm{~L}$ & TBD \\
\hline $\mathrm{NaOH}$ Regen Tank $(0.5 \mathrm{M})$ & TBD & $20,000 \mathrm{~L}$ & TBD \\
\hline NaOH Regen Tank (2.0 M) & TBD & $40,000 \mathrm{~L}$ & TBD \\
\hline Acid Feed Tank & TBD & $100,000 \mathrm{~L}$ & TBD \\
\hline Water Wash Tank (optional) & $\mathrm{TBD}$ & $40,000 \mathrm{~L}$ & TBD \\
\hline Water Wash Tank (optional) & TBD & $40,000 \mathrm{~L}$ & TBD \\
\hline $\mathrm{NaOH}$ Regen Feed Tank & TBD & $40,000 \mathrm{~L}$ & $T B D$ \\
\hline
\end{tabular}

NOTE: Some equipment listed in this table is not shown in the Process Flow Diagram (Figure 4-1). Not all equipment is shown. Process control-instrumentation is not provided in this preliminary list. 
The mass transfer zone length (MTZL) is the length of the resin bed where mass transfer of a particular ion (in this case cesium) is taking place. The MTZL has implication on bed design (Lukchis 1973). For this flowsheet the MTZL is defined as being bounded on the low end by a cesium breakthrough point $\left(C / C_{0}\right)$ of 0.0001 , which is the breakthrough point to produce an equivalent Class A LLW glass for ${ }^{137} \mathrm{Cs}$. The high end of this MTZL definition is a $\mathrm{C} / \mathrm{C}_{0}$ of 0.9 . This value may appear low but is selected because loading after a $C / C_{0}$ of 0.9 , is very slow due to the resins slow kinetics. System optimization would probably rule out operating in a regime above the $C / C_{0}$ of 0.9 .

For CS-100 and NCAW feed $\left(5 \mathrm{M} \mathrm{Na}^{+} \& 25^{\circ} \mathrm{C}\right)$, with a total bed retention time of 1 hour (feed flow rate of $1 \mathrm{CV} / \mathrm{hr}$ ) the MTZL is about $2 / 3$ the length of the total on- 1 ine bed length $(3 \times 7 \mathrm{ft} \times 2 / 3=14$ feet $)$.

The system is divided into 3 columns to take advantage of the MTZL of $2 / 3$ total on-line bed length for the NCAW feed case. Further work with other feed types (Lab data, characterization data, and engineering work) will be evaluated for bed design optimization.

For the R-F, with NCAW feed $\left(5 \mathrm{M} \mathrm{Na}^{+} \& 25^{\circ} \mathrm{C}\right)$, and a total bed retention time of 1 hour (feed flow rate of $1 \mathrm{CV} / \mathrm{hr}$ ) the MTZL is between $1 / 3$ and $2 / 3$ the length of the total on-line bed length (for this case between 7 and 14 feet).

For the DSSF feed $\left(7 \mathrm{M} \mathrm{Na}^{+} \& 25^{\circ} \mathrm{C}\right)$ with $\mathrm{CS}-100$ resin and a total bed retention time of 1 hour (feed flow rate of $1 \mathrm{CV} / \mathrm{hr}$ ) the MTZL is between $2 / 3$ and $4 / 3$ of the total on-line bed length (for this case between 14 and 28 feet).

Although the CS-100 MTZL for DSSF may be longer than the on-1 ine column length, and the system will operate less efficiently (specifically more secondary waste will be generated per amount of cesium removed), meeting cesium removal targets is not precluded. Final selection of resin bed design should be made based on optimizing many factors including different feed types. The marginal performance of CS-100 resin with a high potassium feed such as DSSF is discussed in sections 2, 4, and 11 in the CS-100 document.

For the R-F, with DSSF feed $\left(7 \mathrm{M} \mathrm{Na}^{+} \& 25^{\circ} \mathrm{C}\right)$ and a total bed retention time of 1 hour (feed flow rate of $1 \overline{C V} / \mathrm{hr}$ ) the MTZL is about $2 / 3$ the length of the total on-line bed length (for this case about 14 feet).

The preliminary system design allows either $C S-100$ or $R-F$ resin to be used without major operational differences. 


\subsection{MATERIALS OF CONSTRUCTION}

Stainless steel construction should be possible for both the process make-up vessels and the ion exchange columns. Carbon steel materials are not resistant to the acid used for elution of the cesium. Therefore, they would corrode and fail.

The concentration of halides in some of the waste is high enough that stress corrosion cracking or pitting of certain types of stainless steel may be possible. This possibility should be evaluated during design of the ion exchange system. The alloy selected for construction of the ion exchange columns should be based upon the results of corrosion which is planned for FY-95.

\subsection{UTILITY REQUIREMENTS}

Cooling water for the condensers, and heat exchange equipment is assumed to be supplied by a closed loop system.

Heat to the evaporators is assumed to be supplied by steam. Approximate 7 y $7,187 \mathrm{~L} / \mathrm{h}$ will be evaporated from the NCAW feed stream per hour, and $3,600 \mathrm{~L} / \mathrm{h}$ (when processing NCAW) will be evaporated from the stream to be made into low level glass. Approximately $7.3 \times 10^{3} \mathrm{Kw}\left(2.49 \times 10^{7} \mathrm{Btu} / \mathrm{h}\right)$ are required to evaporate water at that flow rate.

Demineralized water must be supplied to the process make-up tanks and to the ion exchangers. Demineralized water will be supplied by the planned processing facility. 


\subsection{SAFETY AND REGULATORY}

\subsection{HEALTH}

\subsubsection{Exposure to Chemicals}

Chemical exposure is a significant safety consideration when designing the ion exchange system. The piping system and the vessels will be designed in accordance with standards which are meant to protect both workers and the publ ic from problems.

Vessel off-gas systems and cell ventilation systems also protect workers by minimizing exposure to chemical fumes. The vessel off-gas systems, which includes rupture disks, also prevent overpressurization and rupture of vessels.

The system should be designed to prevent and minimize effects of operating errors. However, no design can totally protect against "poor operation". Therefore, work procedures need to be developed to control the handling of chemicals. Procedure compliance further protects workers and minimizes the risk of a chemical overexposure.

\subsubsection{Radiological Exposure}

Radiological exposure is controlled by providing shielding between the processing equipment and personnel. In addition, exposure is also limited by providing contamination barriers between the processing equipment and occupied areas.

The cesium ion exchange columns are a source of high radiation at all times after hot startup. When the ion exchange columns are fully loaded with cesium from NCAW, the radiation field will be approximately $2.7 \times 10^{5} \mathrm{R} / \mathrm{h}$ at contact. The cell should be designed to shield workers from the extremely high radioactivity source inside the cell.

In addition, remote maintenance and operation are essential for this process. The ion exchange system must be designed to minimize maintenance requirements and to maximize the use of remote maintenance. This includes remote change-out of the spent ion exchange material, and remote replacement of high failure rate equipment such as pumps and valves.

\subsection{CHEMICAL SAFETY}

\subsubsection{Resorcinol-Formaldehyde Resin}

The resin is an organic polymer ( $R-F$ copolymer) resin developed by Savannah River Laboratory and manufactured by Boulder Scientific Company. The resin meets the requirements for being nonhazardous with respect to both Occupational Safety and Health Administration (OSHA) and the Resource, Conservation and Recovery Act (RCRA) requirements. 
The material safety data sheet (MSDS) states that the resin is a nonhazardous, totally crosslinked $R-F$ resin. Eye contact requires flushing the eye with water. The manufacturer recommends wearing a dust mask when handling the resin.

The MSDS states that the resin requires a sustained flame to maintain ignition. It is listed as nonflammable, but combustible. No special extinguishing methods are required for putting out a fire which involves this resin. Water, dry chemicals, or carbon dioxide may be used.

$\mathrm{HNO}_{3}$ is the assumed eluant for this flowsheet. In an accident situation, the resin could be exposed to $\mathrm{HNO}_{3}$ concentrations up to $12.2 \mathrm{M}$ ( $57 \mathrm{wt} \%$ ): The $\mathrm{R}-\mathrm{F}$ resin is an organic copolymer. Organic copolymers tend to react with concentrated $\mathrm{HNO}_{3}$ in an exothermic reaction which generates large amounts of heat and gaseous products (see Appendix A for more information). Reaction of concentrated $\mathrm{HNO}_{3}$ with the $\mathrm{R}-\mathrm{F}$ resin could result in overpressurization of the ion exchange column. Therefore, tests should be performed to determine the initiation energy and the energy given off by a reaction of the R-F resin with various concentrations of $\mathrm{HNO}_{3}$. In addition, the ion exchange column, the vessel off-gas system, and the cell off-gas system should be designed to handle this type of pressurization.

$\mathrm{R}-\mathrm{F}$ resin dissolves in $3 \mathrm{M} \mathrm{HNO}_{3}$. Therefore, it is possible that exposure of the R-F resin to $3 \mathrm{M} \mathrm{HNO}$ could cause a large exothermic reaction. Testing needs to be performed to determine how much heat is released when the resin reacts with a 3 M $\mathrm{HNO}_{3}$ solution.

The resin should not be exposed to radiation doses greater than $1 \times 10^{8} \mathrm{R}$ prior to being replaced. Changeout of the $R-F$ resin at this dose prevents severe resin degradation, which could decrease the efficiency of cesium removal. The changeout also prevents resin oxidation problems associated with exposure of degraded resin to $\mathrm{HNO}_{3}$.

In general, the $\mathrm{R}-\mathrm{F}$ resin should not remain 10 aded with ${ }^{137} \mathrm{Cs}$ for more than a few (10 to 15) days. This limits resin exposure and helps prevent severe resin degradation that is likely to occur if the resin remains loaded with cesium.

The exact methods of interim storage and final disposal have not been determined. However, the resin will be converted to the sodium form prior to removal from the IX columns. Then it will be dewatered prior to interim storage or final disposal. (Dewatering the resin simply means that the bulk of the water used for resin removal and transfer is removed by draining the water from the resin.)

Table 9-1 lists suggested precautionary measures which should be employed when using ion exchange resins. 
Table 9-1. Recommended Precautions When Using-IX Resins. ${ }^{a}$

\section{A. Measures Associated with the Chemistry of Resins ${ }^{b}$}

1. Avoid drying of the resin (both in use and storage). Drying of the resin could lead to resin degradation and the formation of potentially exothermic organic compounds.

2. Observe predetermined safe temperature limit.

3. Observe predetermined safe $\mathrm{HNO}_{3}$ concentrations.

4. Observe predetermined safe contact time $1 \mathrm{imit}$ between resin and specified concentration of $\mathrm{HNO}_{3}$.

5. Change out the resin at a predetermined safe level of exposure to radiation. Exposure of organic resins to radiation results in resin degradation and the formation of potentially exothermic organic compounds.

6. Limit the diameter of the IX vessels.

\section{B. Measures Generally Applicable to Safe Chemical Processing ${ }^{b}$}

1. Provide pressure relief valve on IX column to avoid rupture.

2. Limit size of column to predetermined safe size.

3. Provide adequate blending of all $\mathrm{HNO}_{3}$ solutions.

4. Monitor concentrations of all streams to the IX columns.

5. Monitor temperatures in columns.

6. Provide high-temperature alarm so that column is flushed internally with water when alarm sounds.

7. Observe predetermined precautionary measures when equipment stands idle.

8. Vent column when not in use.

9. Follow tested and approved procedures.

10. Improvise cautiously and with adequate protection during trouble.

11. Provide an external column flush.

12. Regenerate resin with a continuous flow of $\mathrm{HNO}_{3}$ to dissipate some of the heat of reaction outside of the column.

13. Do not allow loaded resin to stand for more than 5 days without eluting the cesium from the column.

Most of the precautionary measures were taken from references (K1em, 1977) and (Miles 1968).

'In the absence of definitive tests for the specific situation, the various specified safe limits are unknown and cannot therefore be stated. 


\subsubsection{Nitric Acid}

$\mathrm{HNO}_{3}$ is a strong oxidizing agent. This acid is highly toxic and is extremely destructive to human tissue. Protective equipment must be used when handling $\mathrm{HNO}_{3}$.

$\mathrm{HNO}_{3}$ is the proposed eluant for removal of cesium from the resin. The proposed eluant concentration is $0.5 \mathrm{M}$. This dilute concentration of $\mathrm{HNO}_{3}$ does not create a significant exothermic reaction when in contact with the R-F resin. Also, $0.5 \mathrm{M} \mathrm{HNO}_{3}$ does not significantly degrade the ion exchange resin.

As stated previously, an accident situation could result in concentrated (12.2M) $\mathrm{HNO}_{3}$ contacting the ion exchange resin. The possibility of this type of reaction occurring can be minimized by designing the system to prevent the addition of concentrated $\mathrm{HNO}_{3}$ to the ion exchange columns and by following approved chemical makeup procedures. The system should be designed with engineered safety features to prevent contact of concentrated acid with R-F resin. Also, as mentioned above, tests to determine the initiation energy and the energy given off by the reaction of $\mathrm{R}-\mathrm{F}$ resin with different $\mathrm{HNO}_{3}$ concentrations must be performed.

$\mathrm{HNO}_{3}$ is noncombustible. However, it must be kept away from combustible materials because it may react with them to cause a fire.

\subsubsection{Sodium Hydroxide}

Sodium hydroxide is a corrosive which causes chemical burns to human tissue. As received, the sodium hydroxide solution is a clear liquid with a concentration of 19M. The sodium hydroxide solution is diluted to 0.5 or $2 \mathrm{M}$ before it is used for regeneration of the ion exchange resin. The equipment must be designed to handle the heat generated during dilution of the sodium hydroxide.

Protective equipment must be used when handling sodium hydroxide. Procedures will ensure that safe practices are used when handling sodium hydroxide.

The MSDS recommends the use of dry chemical powder for extinguishing a fire. It also states that toxic fumes are emitted under fire conditions. 


\subsection{ENVIRONMENTAL CONCERNS}

As received, the $R-F$ resin is not a hazardous material. Therefore, it should not be a hazardous waste for disposal. The MSDS does not indicate that a TCLP for RCRA has been performed. Therefore, a TCLP test should be performed prior to disposal.

Once the resin is used, disposal as mixed waste is required because of chemicals and trace radioactive material which will remain on the resin. The disposal method is not established at this time. However, the resin must be eluted to remove the cesium prior to being disposed of or stored. This will minimize radiation caused resin degradation.

$\mathrm{HNO}_{3}$ and sodium hydroxide wastes may be hazardous (concentration dependent) and must be disposed of properly. 
WHC-SD-WM-TI-638 REV 0

This page intentionally left blank. 


\subsection{ESSENTIAL MATERIALS}

\subsection{RESORCINOL-FORMALDEHYDE RESIN}

$R-F$ resin is a crosslinked organic polymer ( $R-F$ copolymer) resin developed by Savannah River Laboratory and manufactured by Boulder Scientific Company. The resin was developed to have a high selectivity for cesium.

The resin is prepared by condensing the potassium salt of resorcinol with formaldehyde in an aqueous solution. The resulting gel is dried at about $100{ }^{\circ} \mathrm{C}$ (Kurath et al. 1994). The resin is then crushed. The active sites in the resin are phenolic in nature. The crosslinking agent in this condensation polymer is formaldehyde: Figure 10-1 shows the structure of R-F resin.

R-F resin is not a standard manufacturer's item. The manufacturer wi11 need to have a special manufacturing run each time the resin is ordered. Scheduling and performance of a special manufacturing run increases the time that it takes to obtain the resin.

$\mathrm{R}-\mathrm{F}$ resin is normally transported and stored in 55 gal drums. The drums require protected storage. The requirements for the protected storage are not known at this time. Drum handling equipment should be considered to improve handling of the resin.

Table 10-1 lists particle size distributions for the resin. The latest specifications require the resin to be similar to $\mathrm{BSC}-210$ with regard to preparation and particle size. Pacific Northwest Laboratory generated the data in Table 10-1. The physical properties of the resin are given in Table 10-2.

Table 10-1. Particle Size Distribution for Resorcinol-Formaldehyde Resin.

\begin{tabular}{|c|c|c|}
\hline \multirow{2}{*}{ Mesh size of resin material } & \multicolumn{2}{|c|}{ Resin manufacturer batch designation } \\
\cline { 2 - 3 } & BSC-187 & BSC-210 \\
\cline { 2 - 3 } & Weight percent & Weight percent \\
\hline$>70$ & 2 & 7.1 \\
\hline $70-45$ & 58 & 81.3 \\
\hline $45-35$ & 40 & 11.5 \\
\hline $35-25$ & 0 & 0.1 \\
\hline $25-18$ & 0 & 0 \\
\hline$<18$ & 0 & 0 \\
\hline
\end{tabular}


Table 10-2. Physical Properties of R-F Resin (Kurath et a1. 1994).

\author{
Particle size \\ $0.26-0.42 \mathrm{~mm}^{(a)}$ \\ Bulk Density, Na form (g dry \\ $0.461^{(b)}, 0.34^{(c)}, 0.36^{(d)}$ \\ resin/mL swollen resin) \\ Void Fraction \\ $0.5^{(e)}$ \\ Volume change $\left(\mathrm{Na}^{+}\right.$to $\mathrm{H}^{+}$form) \\ $3035 \%^{(f)}$ \\ Optimum $\mathrm{pH}$ for Cs loading \\ $\geq 12^{(g)}$ \\ Maximum temperature \\ (h) \\ Ion exchange capacity (meq/gm dry \\ resin) \\ $2.85^{(i)}, 3.4^{(j)}$

\section{Legend} \\ (a) As received from Boulder Scientific (the potassium state). \\ (b) Dried for $24 \mathrm{~h}$ at $85^{\circ} \mathrm{C}$. Value measured in water. Resins \\ swell in $\mathrm{NaOH}$. \\ (c) Bray et a7. 1992 . \\ (d) Bibler and Wallace 1990 . \\ (e) Estimated based on the amount of water $(0.7) \mathrm{mL}$ displaced by $1 \mathrm{~g}$ resin \\ and the bulk density of the as-received resin $(0.67 \mathrm{~g} / \mathrm{mL})$. \\ (f) Estimate based on volume shrinkage during acid elution (see \\ Bray et a1. 1990). \\ (g) Kurath et a1. 1994. \\ (h) Not available at this time, but probably close to $80{ }^{\circ} \mathrm{C}$. \\ (i) Bibler and Wallace 1990; Basis is air dried resin. \\ (j) Based on the amounts of $\mathrm{Na}^{+}, \mathrm{Cs}^{+}, \mathrm{K}^{+}$, and $\mathrm{Rb}^{+}$which were released from \\ the resin during $\mathrm{HCOOH}$ elution; Basis is resin dried at $85^{\circ} \mathrm{C}$ for $24 \mathrm{~h}$.
}


Figure 10-1. Chemical Structure of ResorcinolFormaldehyde Resin.

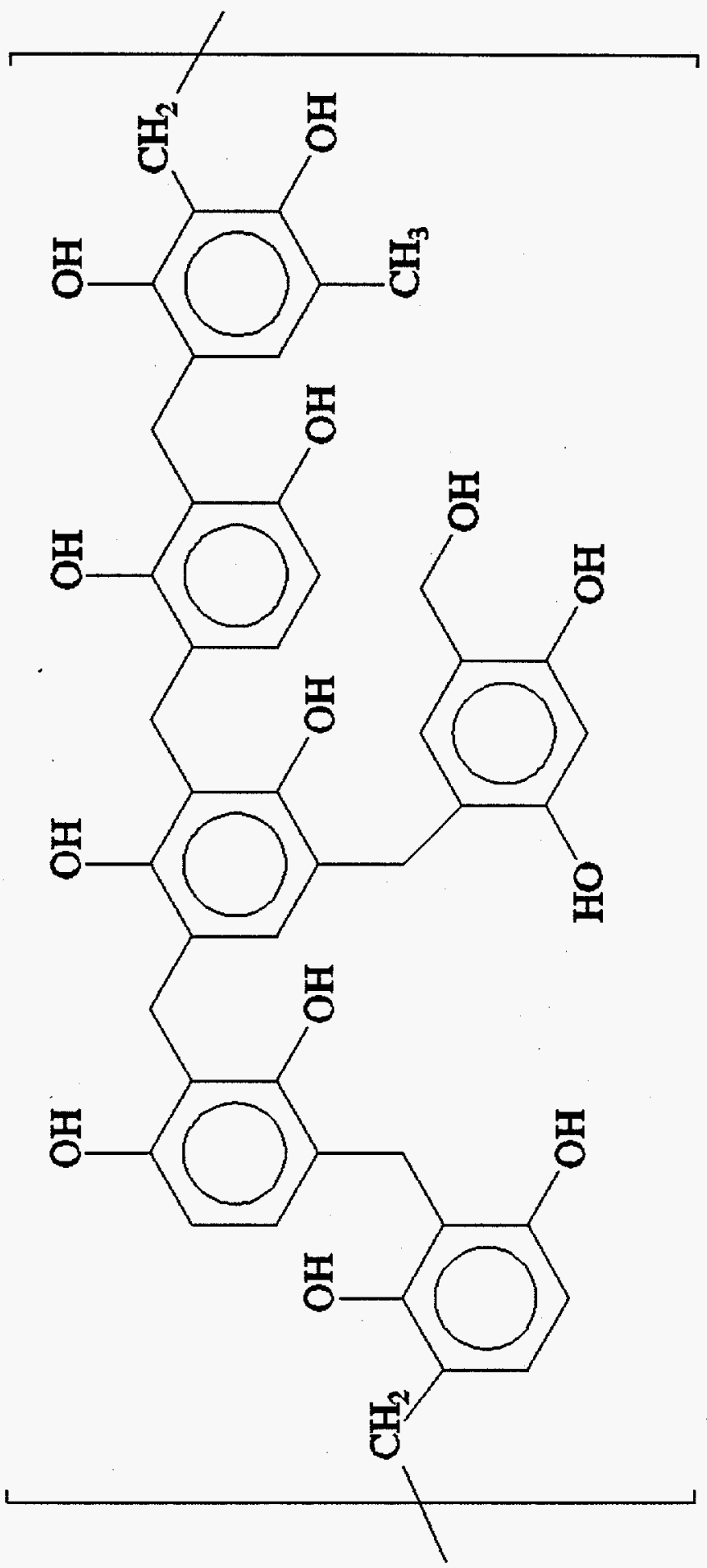

$\stackrel{0}{\stackrel{5}{\dagger}}$

ํํำ ํํㅇ

$\infty$ 을 文

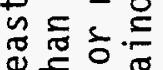

을

넝ㅇㅇㅇ

틈

Z

$>n \subseteq=$

$20 \div$

n⿺ 万人

0 乎

논 $\frac{\pi}{5}$

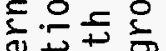

$+0$

$\pm \cong$

$24 \div$

잉

으요

产厂些

$\pm \Phi+$

$\because \frac{\pi}{ \pm} \frac{0}{ \pm}$

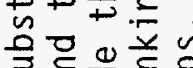

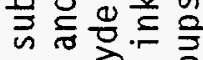

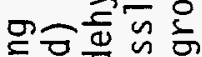

동응

人苛芯元

ब.

$\stackrel{\square}{0} \stackrel{0}{2}$

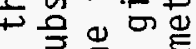

幽永乐

$\Psi \leq 4+0$

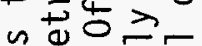

出烍.

वि लि

언

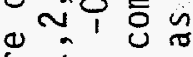

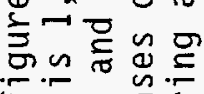

$4=\frac{1}{\frac{1}{2}} \frac{\mathrm{s}}{\mathrm{s}}$

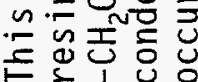


$\mathrm{R}-\mathrm{F}$ resin appears to be prone to air oxidation in alkaline media. Work to determine the extent and rate of oxidation is being conducted by Pacific Northwest Laboratory, Clark Atlanta University, and Westinghouse Savannah River.

Radiation Effects on Resorcinol-Formaldehyde Resin--Organic cation exchangers contain bonds between functional groups and the polymer matrix which are relatively unstable. These weaker linkages are more likely to break under the influence of radiation (Gangwer 1977). This results in the destruction of the original organic compounds comprising the resin and formation of different types of organic compounds. These new compounds are often simpler in structure, and often react more vigorously with $\mathrm{HNO}_{3}$ than the original compounds.

When ionizing radiation breaks the polymer linkages, it also results in a slow loss of ion exchange capacity. Performance loss for R-F resin is complicated and conflicting results have been obtained. One study (Prignano 1989) showed that the ion exchange capacity decreases by around $1.0 \times 10^{6} \mathrm{R}$, increases back to approximately the original capacity by $1.0 \times 10^{7} \mathrm{R}$, and starts to decrease again at approximately $1.0 \times 10^{8} \mathrm{R}$ of total exposure. A more recent study (Bibler, 1994) stated that radiation doses up to $1.0 \times 10^{8} \mathrm{R}$ do not affect the performance of R-F resin. But, significant performance decrease is seen by $2.5 \times 10^{8} \mathrm{R}$.

Degradation of the resin by ionizing radiation also results in a slow evolution of hydrogen gas. Tests regarding the extent of the gas generation are currently being performed. The results have not yet been published.

\subsection{NITRIC ACID}

$\mathrm{HNO}_{3}$ is a standard chemical used at the Hanford Site. $\mathrm{HNO}_{3}$ is a clear liquid with a strong odor. It is a strong oxidizing agent which cannot be stored near organic materials.

$\mathrm{HNO}_{3}$ (12.2M concentration, 57 wt\%) will be received using standard procedures. The acid will be diluted to $0.5 \mathrm{M}$ before it is used for eluting the cesium from the resin. The location for performing the dilution needs to be evaluated during conceptual design.

$\mathrm{HNO}_{3}$ would be received and stored in facilities specifically designed and built for that purpose. The $\mathrm{HNO}_{3}$ would be diluted and prepared for process use in the Aqueous Makeup (AMU) area. 


\section{WHC-SD-WM-TI-638 REV 0}

\subsection{SODIUM HYDROXIDE}

Sodium hydroxide is a standard chemical used at the Hanford Site. As received, the sodium hydroxide solution is a clear liquid with a concentration of $19 \mathrm{molar}(50 \mathrm{wt} \%)$. The sodium hydroxide solution will be diluted to either 0.5 molar or 2 molar before it is used for regeneration of the ion exchange resin. The location that the dilution occurs will need to be evaluated during conceptual design.

Sodium hydroxide would be received and stored in facilities specifically designed and built for that purpose. The sodium hydroxide would be diluted and prepared for process use in the Chemical Makeup area. 
WHC-SD-WM-TI-638 REV 0

This page intentionally left blank. 


\subsection{PROCESS ALTERNATIVES}

\subsection{ION EXCHANGE MATERIALS}

CS-100 resin is the baseline process for cesium ion exchange. This flowsheet provides information on the use of $R-F$ resin as an alternative to $\mathrm{CS}-100$.

A comparison of the $R-F$ resin and the $C S-100$ resin is given in Section 11.1 .1 below.

\subsubsection{Comparison of Resorcinol-Formaldehyde Resin to CS-100 Resin}

CS-100 has been used commercially in the past. However, the manufacturer, Rohm and Haas, has stopped manufacturing the resin except as a special order item. This means that both the R-F resin and the CS-100 resin are special order products which will only be produced upon receipt of order, and neither is readily available. Resin orders will have to be carefully planned to allow for the lead time required to order a sole source special manufactured product.

Testing has shown that the $R-F$ resin has a greater cesium loading capacity than CS-100, the baseline IX material (Kurath et al. 1994). Also, "The R-F resin was found to be roughly 6-12 times more selective for cesium at $25^{\circ} \mathrm{C}$." (Kurath et a]. 1994) This means that the same volume of R-F resin can process more waste than the CS-100 resin.

The R-F resin can also be loaded at a faster rate than the CS-100 without early breakthrough occurring. (Kurath et al. 1994) This allows greater throughput with the same size equipment when compared to CS-100.

The higher selectivity and capacity of the $R-F$ resin result in a higher ratio of total waste processed to water and eluant volumes used as compared to the CS-100 resin. This decreases the amount of high level cesium product, which has a significant impact on the disposal costs. On a per elution basis however, the $R-F$ resin requires about 2-3 times more acid for elution than the CS-100 resin.

The $R-F$ resin has been seen to agglomerate while shrinking causing channeling during laboratory scale elution testing. The channeling caused by the agglomeration while shrinking phenomenon is believed to have caused cases of poor elution performance for the $R-F$ resin during laboratory scale testing. This channeling has not been seen for the CS-100 resin. Reversible shrinkage is normal for a weak acid cation exchange resin. This R-F resin is estimated to shrink by about $30-35 \%$. Further study is needed to verify that channeling caused by the combination of agglomeration while shrinking during elution of the $R-F$ resin would not significantly impact the predicted performance. 
The amount of regeneration chemicals required is also less with $R-F$ resin than with CS-100 resin. R-F resin use would result in the generation of less depleted cesium product, which would be sent to the low level glass plant. Therefore, waste disposal costs are decreased.

Tables 11-1 and 11-2 summarize the differences between the total mass of elution chemicals, regeneration chemicals, HLW, and LLW for processing NCAW and DSSF using the R-F resin and the CS-100 resin.

Table 11-1. Comparison of Waste and Chemical Streams for NCAW Treatment.

\begin{tabular}{|l|c|c|c|c|}
\hline \multirow{2}{*}{ Description } & \multicolumn{2}{|c|}{ CS-100 resin } & \multicolumn{2}{c|}{$\begin{array}{c}\text { Resorcinol- } \\
\text { formaldehyde resin }\end{array}$} \\
\cline { 2 - 5 } & $\begin{array}{c}\text { Mass in } \\
\text { MT }\end{array}$ & Volume in L & $\begin{array}{c}\text { Mass in } \\
\text { MT }\end{array}$ & Volume in L \\
\hline $\begin{array}{l}\text { Depleted Cesium Product to } \\
\text { evaporator }\end{array}$ & 6,480 & $5.53 \mathrm{E}+06$ & 5,890 & $4.75 \mathrm{E}+06$ \\
\hline Spent resin to LLW & 18 & $4.0 \mathrm{E}+04$ & 3.7 & $8.00 \mathrm{E}+03$ \\
\hline LLW glass feed from IX & 3,270 & $2.34 \mathrm{E}+06$ & 3,210 & $2.27 \mathrm{E}+06$ \\
\hline $\begin{array}{l}\text { Eluate Concentrator Feed } \\
\text { (HLW from IX) }\end{array}$ & 1,340 & $1.32 \mathrm{E}+06$ & 554 & $5.46 \mathrm{E}+05$ \\
\hline $\begin{array}{c}\text { Neutralized Eluate } \\
\text { (HLW glass feed from IX) }\end{array}$ & 47.5 & $4.66 \mathrm{E}+04$ & 25.1 & $1.61 \mathrm{E}+04$ \\
\hline
\end{tabular}


Table 11-2. Comparison of Waste and Chemical Streams for DSSF Waste Treatment.

\begin{tabular}{|l|c|c|c|c|}
\hline \multirow{2}{*}{ Description } & \multicolumn{2}{|c|}{ CS-100 resin } & \multicolumn{2}{c|}{$\begin{array}{c}\text { Resorcinol- } \\
\text { formaldehyde resin }\end{array}$} \\
\cline { 2 - 5 } & $\begin{array}{c}\text { Mass in } \\
\text { MT }\end{array}$ & Volume in L & $\begin{array}{c}\text { Mass in } \\
\text { MT }\end{array}$ & Volume in L \\
\hline $\begin{array}{l}\text { Depleted Cesium Product to } \\
\text { evaporator }\end{array}$ & 166,000 & $1.35 \mathrm{E}+08$ & 106,000 & $7.54 \mathrm{E}+07$ \\
\hline Spent resin to LLW & 1,071 & $2.34 \mathrm{E}+06$ & 51.6 & $1.12 \mathrm{E}+05$ \\
\hline LLW glass feed from IX & 84,500 & $5.32 \mathrm{E}+07$ & 49,600 & $7.98 \mathrm{E}+07$ \\
\hline $\begin{array}{l}\text { Eluate Concentrator Feed } \\
\text { (HLW from IX) }\end{array}$ & 83,200 & $8.19 \mathrm{E}+07$ & 11,600 & $1.14 \mathrm{E}+07$ \\
\hline $\begin{array}{c}\text { Neutral ized Eluate } \\
\text { (HLW glass feed from IX) }\end{array}$ & 3,460 & $2.66 \mathrm{E}+06$ & 512 & $3.87 \mathrm{E}+05$ \\
\hline
\end{tabular}

The tables above show that less chemicals are used, and less HLW is generated using $R-F$ as the ion exchange resin versus CS-100. The general relationship of chemicals used and HLW produced to the amount of waste processed should be similar for other types of feed to the IX system.

A good estimate of the difference in the amount of glass canisters which will result from processing the different types of waste is not currently available. However, If the HLW is not neutralized prior to being glassified, the sodium, potassium, and cesium from IX processing is not the controlling factor on the volume of HLW glass. Even though the sodium may not be the controlling factor with regard to HLW glass volume, the sodium in the waste does affect the corrosivity of the molten glass. Therefore, the sodium concentration in the HLW should be minimized.

The quote below from a PNL letter report provides a general view of the difference in secondary waste generation.

"A preliminary examination of a 4-column carousel operation indicates that the R-F resin requires about $10 \%$ of the total number of column loadings as the CS-100 resin for a given quantity of waste. For processing a NCAW feed of average composition, the eluate from R-F resin loading would have a total cation/cesium mole ratio of about 15 , while the eluate from the CS-100 resin would have a total cation/cesium mole ratio of about 70 . For processing a DSSF feed of average composition, the resulting eluate from a R-F loading would have a total cation/cesium mole ratio of about 125 while the eluate from the CS-100 resin would have a total cation/cesium mole ratio of about 1,100" (Kurath et al. 1994). 
- Temperature does not have as great an effect on the loading capacity of $R-F$ resin as it does with the CS-100 resin (Kurath et a1. 1994). The $R-F$ resin was 20 times more selective for the same feed conditions at $40{ }^{\circ} \mathrm{C}$ because the R-F resin is less influenced by temperature (Kurath et al. 1994). The $R-F$ resin can be loaded at a higher temperature (up to $40{ }^{\circ} \mathrm{C}$ ) with only an $11 \%$ decrease in capacity compared to a $30 \%$ decrease in capacity for CS -100 (Kurath et a1. 1994). The decreased temperature sensitivity associated with the $R-F$ resin is a desired trait.

The radiation stability of the $R-F$ resin is less than that of the CS-100 resin. The loss in capacity of the R-F resin with exposure to radiation is greater than with the CS-100 resin. Capacity loss is seen by $2.5 \times 10^{8}$ (Bibler 1994 ) rather than being able to be exposed to $>1.0 \times 10^{9} \mathrm{R}$ without significant capacity loss occurring (Prignano, 1989). In addition, it appears that the $R-F$ resin capacity may decrease, then return to approximately the original capacity before finally decreasing again (Prignano, 1989).

In general, the chemical stability of CS-100 and R-F resins appear to be similar. The manufacturer's data states that the CS-100 resin should not be in contact with $\mathrm{HNO}_{3}$ concentrations greater than $1 \mathrm{M}$ at $25{ }^{\circ} \mathrm{C}$. Both 1 ose capacity at about $2 \%$ to $3 \%$ per cycle (Kurath, et a1. 1994 and Bray, et al. 1990). Greater resistance to degradation by $\mathrm{HNO}_{3}$ and lower amounts of heat given off by degradation reactions is desirable because it will improve safety.

The CS-100 resin is probably more resistant to chemical degradation caused by exposure to the waste feed than $R-F$ resin. During a meeting on August 4, 1994, Dr. Jane Bibler stated that resin degradation can be seen after 200 hours of exposure of the $R-F$ resin to caustic. The concentration of caustic was not stated. This implies that the resin may degrade significantly due to contact with the waste. However, that type of problem has not been identified during tests where the resin remained in contact with waste simulants for periods greatly in excess of 200 hours.

\subsubsection{0ther Types of Ion Exchange Materials}

Some other types of ion exchange materials are under consideration for possible use for ion exchange. The some of the primary types are described briefly below.

11.1.2.1 Crystalline Silico-Titanates. Crystalline silico-titanate (CST) ion exchange material is an inorganic ion exchange material which was developed by Sandia National Laboratory in conjunction with Texas A\&M University. It has a very high selectivity for cesium in both acidic and highly alkaline media.

CSTs also have a high capacity, which minimizes the amount of material needed to remove the cesium from the waste. CSTs are a non-regenerable ion, exchange material when used for cesium removal. However, the CST material is highly resistant to radiolytic degradation. The cesium loaded CST material would probably be incorporated into the HLW glass for final disposal. 
CSTs are not commercially available. UOP* is currently developing an engineered form of the material and developing a method of producing the engineered material on an industrial scale.

11.1.2.2 Ligand-embedded Membrane Technology. This technology is basically supporting the ion exchange material on a membrane. The membrane is made into a "filter" type cartridge. This has a high capacity and good selectivity for cesium. However, the materials are not available commercially at this date. The radiation resistance of this material is currently unknown.

11.1.2.3 Modified Mica. Mica is a naturally occurring rock which has good ion exchange properties. Mica can be made synthetically, so that it has better ion exchange characteristics. The synthetic material can be modified so that the material is selective for cesium. This material is highly radiation resistant. The material is in the development stage, and it may not be commercially available for several years.

\subsection{LOADING TEMPERATURE}

The loading temperature selected for this flow sheet is $25^{\circ} \mathrm{C}$. The evaporator bottoms (Stream number 427) are cooled prior to filtration. Based on the available data, loading is effective over a range of temperatures from $10{ }^{\circ} \mathrm{C}$ to $40{ }^{\circ} \mathrm{C}$ (Kurath et a1. 1994).

Loading at a temperature below $25^{\circ} \mathrm{C}$ is not used, even though a lower feed temperature increases the capacity of the resin for loading cesium. Cooling the temperature below $25^{\circ} \mathrm{C}$ also requires additional cooling capacity and the use of increased cooling water. Increased cooling may also increase solids formation in the feed system.

Loading at temperatures above $25^{\circ} \mathrm{C}$ is not used because the resin capacity for loading cesium is reduced.

\subsection{ELUTION TEMPERATURE}

The $R-F$ resin does not elute well at temperatures below $40{ }^{\circ} \mathrm{C}$ (Kurath et al. 1994). Therefore, elution at a lower temperature is not recommended.

*UOP is a company that manufactures molecular sieves. 


\subsection{SODIUM CONCENTRATION IN COLUMN FEED}

The ratio of sodium to cesium in the waste is very important with regard to how much cesium can be loaded on the column. This is because the sodium competes with the cesium for the ion exchange sites. In addition, the concentration of the sodium also affects the performance of the column. Dilution of the waste to reduce the sodium concentration also decreases the amount of cesium which can be loaded onto the resin (Kurath et al. 1994). Therefore, dilution of the waste beyond the point at which precipitation will not occur, will decrease the resin loading and increase secondary waste generation.

The TWRS Process Flowsheet (Orme 1994) was based upon 7M sodium in the cesium IX feed to minimize both precipitation problems and storage requirements. This flowsheet used a $5 \underline{M}$ sodium concentration for the cesium IX feed for the NCAW mass balance because no test data is available for NCAW at 7M sodium. 7M sodium was used for the DSSF mass balance data.

\subsection{ELUENT}

Two eluant solutions, $\mathrm{HCOOH}$ and $\mathrm{HNO}_{3}$, have been laboratory tested with the R-F resin. The $\mathrm{HNO}_{3}$ was chosen for this flowsheet because it is easier to handle, and does not have as many safety problems associated with its storage and recycle. $\mathrm{HNO}_{3}$ is compatible with the existing waste and is easier to recover and recycle. In addition, it is also easier to dispose of than $\mathrm{HCOOH}$.

The concentration of $\mathrm{HNO}_{3}$ used to elute the R-F resin may change. Dr. Jane Bibler tested $\mathrm{MM} \mathrm{HNO}_{3}$ as an eluant. The resin can be completely eluted with $10 \mathrm{BVs}$ of $1 \mathrm{M} \mathrm{HNO}_{3}$. It takes 20 volumes of $0.5 \mathrm{M} \mathrm{HNO}_{3}$ to completely elute the R-F resin. One of the reasons is that the resin has a cesium selectivity of 6 at a $\mathrm{pH}$ of 0.0 .

Special care will be needed if $1 \underline{M} \mathrm{HNO}_{3}$ is used as an eluant. In discussions with $\mathrm{Dr}$. Jane Bibler, she stated that the resin dissolves in $3 \mathrm{M}$ $\mathrm{HNO}_{3}$. This eluant concentration leaves a narrow safety margin for operation of the cesium ion exchange system.

\subsection{CONCENTRATION OF SODIUM HYDROXIDE REGENERATION SOLUTION}

In this flowsheet, the regeneration was done in two steps. A dilute solution was used first. This allowed the resin to be converted to the sodium form slowly to minimize problems associated with resin expansion during the conversion. The amount of more concentrated solution, should be minimized through optimization. This would reduce the mass of sodium and hydroxide being sent to waste.

Dr. Jane Bibler recommends using the same concentration of $\mathrm{NaOH}$ to regenerate the resin as the waste that will be fed through the system. Tests done to date by PNL have not verified this recommendation. 


\subsection{AMOUNT OF SODIUM HYDROXIDE REGENERATION SOLUTION}

The amount of sodium hydroxide used for this flowsheet was conservative. Approximately 4 times the number of equivalents of sodium which can be loaded onto the resin were used. The amount can probably be reduced significantly. Testing should be performed to optimize the amount of sodium hydroxide used. This will reduce the amount of sodium in the stream sent to the low level glass plant.

\subsection{SODIUM HYDROXIDE RINSE AT THE END OF EACH FEED CYCLE}

The need for having a $\mathrm{NaOH}$ rinse at the completion of each waste feed cycle is currently unknown. The $\mathrm{NaOH}$ rinse (2 to $3 \mathrm{BVs}$ of $\mathrm{NaOH}$ ) would flush out the interstitial waste, thereby preventing precipitation of aluminum containing compounds on the resin when the water rinse is performed. Testing to determine the need for the $\mathrm{NaOH}$ rinse should be performed. This would allow minimization of the chemicals sent to waste if the $\mathrm{NaOH}$ rinse in not actually needed.

\subsection{COLUMN CONFIGURATION}

A three column online train with a one hour retention time has been selected for use in this flowsheet because based on data with DSSF simulant and fresh (previously unused or uncycled) R-F resin (Kurath et al.), this system is estimated to be a preliminary optimum of elution chemical usage, capital costs, and operating and maintenance complexity. More rigorous efforts are needed to better optimized total number of columns based on these parameters.

Single column (non-carousel) systems or carousel systems of less than four columns in total, may have advantages over the system selected for this flowsheet in the areas of operation, maintenance and lower capital cost. The operating complexity and added safety risks associated with a four column carousel system may be unacceptable.

Parallel CS-IX systems may be required to achieve the required online processing ratio and the desired flowrate while minimizing safety problems.

other configurations are possible, and should be taken into consideration during conceptual design of the system.

\subsubsection{Number of Ion Exchange System Passes}

The high cesium removal efficiency required (greater than $99 \%$ ) for a single pass ion regenerable exchange process has not been demonstrated in the laboratory because of the large amount of radioactive cesium tracer which would be required. Future tests should demonstrate that it is possible to achieve the required DF in the laboratory. 
However, even if the required efficiency can be achieved in the laboratory, it may be difficult to maintain that type of DF with plant scale equipment. Therefore, a multiple pass system may be required. A multiple pass system normally contains additional tanks and two or more sets of ion exchange columns. Therefore, it costs more. A multiple pass system contains a collection tank on the outlet of the primary set of ion exchange columns to feed the secondary set of ion exchange columns. The additional equipment increase the maintenance requirements. The additional set(s) of ion exchange columns increases the operating complexity. Therefore, a multiple pass system will not be used unless the product requirements cannot be met using any other method.

\subsubsection{Number of Ion Exchange Columns in System}

The three on-line resin beds selected by this design can be considered as a single bed during loading because they are connected in series. The size of this single bed is determined by cesium removal target and resin performance under the given conditions. The goal of dividing up this single bed is to "pick off" a piece that is just fully loaded before the cesium concentration in the effluent of the last column exceeds the cesium target specification. In this way a more fully cesium loaded bed will be eluted thus minimizing elution/regeneration and wash chemicals added into the streams to HLW and LLW.

Laboratory data indicates that for the CS-100 resin with NCAW a four total column (three columns online) carousel type system will be more efficient than a system with fewer columns, however more columns than four total may not be significantly more efficient than the four column system. Laboratory data for DSSF indicates that a system of more than four total columns would be more efficient than a system of only four columns. The more columns there are in a system however, the more complicated the system is to operate and maintain, and increases capital costs. Operation of a multiple column carousel type system could be extremely complex, especially when faced with off-standard conditions, to the point that required safety margins might not be met. Parallel ion exchange systems of one or two columns in series are alternatives to the design proposed by this flowsheet.

\subsubsection{Polishing Column}

An ion exchange column which is not part of the carousel system may be added as a final polishing step. This column should not be a regenerated column. The IX material in the polishing column can be either the same material used in the carousel system, or a different type of IX material. The addition of this column would minimize the probability of radioactive cesium above the required limits being in the depleted cesium product stream. It would also minimize the effects of process problems such as valve leakage.

The spent ion exchange material from the polishing column would be above class $A$ limits and possibly above class $C$ limits. If the IX material cannot be eluted to remove the cesium, it must be disposed of as HLW. However, if the ion exchange material can be eluted, it should be eluted prior to removal from the polishing column for storage and disposal (probably as LLW). 
However, it should not be reused after elution. Because operation is always with fresh resin, the possibility that cesium from the polishing column would add to the cesium in the depleted cesium product stream is minimized.

\subsection{FILTERS}

Filters are required both before and after the ion exchange columns. The filter before the IX columns is needed to remove solids from the waste before it is processed. This minimizes problems associated with resin fouling and plugging of the ion exchange columns.

The post cesium ion exchange filter serves to protect the quality of the LLW feed by trapping either resin which may have escaped the ion exchange columns due to screen failure, solids which have passed the pre-cesium ion exchange filter or solids which have precipitated within the columns. 
WHC-SD-WM-TI-638 REV 0

This page intentionally left blank. 


\subsection{PROCESS MATERIAL BALANCES AND FLOW DIAGRAMS}

A process flow diagram for the CS-IX process described by this flowsheet is shown in Figure 12-1. The purpose of this diagram is to show the basic concept of the process. Not all tanks and process streams are shown.

\subsection{NCAW MATERIAL BALANCE}

The estimated cesium inventory in NCAW is $1.15 \times 10^{7} \mathrm{Ci}{ }^{137} \mathrm{Cs}$. The cesium inventories were obtained from WHC-EP-0616, p. D-51. The decay daughters are not included. The radionuclides have been decayed to the end of 1995 . The isotopic ratio for ${ }^{137} \mathrm{Cs}$ is about 0.38 . Since cesium exists in various isotopic forms in the tank waste, for example ${ }^{137} \mathrm{Cs}$, and ${ }^{134} \mathrm{Cs}$, this isotopic ratio for ${ }^{137} \mathrm{Cs}$ in NCAW tells us that $38 \%$ (wt.) of the total mass of cesium in NCAW is ${ }^{137} \mathrm{Cs}$. An average molecular weight of $134 \mathrm{~g} \mathrm{Cs}^{+} / \mathrm{mole}$ is used to represent the average molecular weight of the various cesium isotopes in the tank waste.

$$
\begin{gathered}
\frac{1.15 \times 10^{7} C_{i C s}{ }^{137}}{\text { NCAW }}\left|\frac{g C s^{137}}{86.6 C i C s^{137}}\right| \frac{g C s^{+}}{0.38 \mathrm{gCs}^{137}} \mid \frac{\mathrm{kg}}{1,000 \mathrm{~g}} \\
=350 \mathrm{~kg} \mathrm{Cs}^{+}
\end{gathered}
$$

Tables 12-1 through 12-8 summarize the material balance for use of $\mathrm{R}-\mathrm{F}$ resin as an ion exchange material to remove cesium from Neutralized Current Acid Waste. 
WHC-SD-WM-TI-638 REV 0

This page intentionally left blank. 
Table 12-1. Cesium Ion Exchange, Neutralized Current Acid Waste, Resorcinol-Formaldehyde Resin, Major Process Stream Data. (2 sheets)

\begin{tabular}{|c|c|c|c|c|c|c|c|}
\hline \multicolumn{2}{|c|}{ Stream number } & \multicolumn{2}{|c|}{--} & 120 & 520 & \multicolumn{2}{|c|}{420} \\
\hline \multicolumn{2}{|c|}{ Description } & \multicolumn{2}{|c|}{ In tank } & $\begin{array}{l}\text { Solutions for } \\
\text { retrieval and } \\
\text { sludge } \\
\text { washing }\end{array}$ & $\begin{array}{l}\text { Sludge washed } \\
\text { sol ids } \\
\text { to HLW glass }\end{array}$ & \multicolumn{2}{|c|}{ Sludge washed supernate } \\
\hline \multicolumn{2}{|c|}{$\begin{array}{l}\text { Temperature } \\
\left({ }^{\circ} \mathrm{C}\right)\end{array}$} & \multicolumn{2}{|c|}{--} & 25 & 25 & \multicolumn{2}{|c|}{60} \\
\hline \multicolumn{2}{|c|}{ Total volume (L) } & \multicolumn{2}{|c|}{$7.32 E+06$} & $6.46 E+06$ & $3.75 E+06$ & \multicolumn{2}{|c|}{$9.90 E+06$} \\
\hline \multicolumn{2}{|c|}{$\begin{array}{l}\text { Instantaneous } \\
\text { design flow rate } \\
(\mathrm{L} / \mathrm{min})\end{array}$} & \multicolumn{2}{|c|}{$163^{(a)}$} & 143 & $83^{(a)}$ & \multicolumn{2}{|c|}{220} \\
\hline \multicolumn{2}{|c|}{$\begin{array}{l}\text { Total suspended } \\
\text { solids (ppm) }\end{array}$} & \multicolumn{2}{|c|}{$\cdots$} & 0 & $\cdots$ & \multicolumn{2}{|c|}{237} \\
\hline \multicolumn{2}{|c|}{ Specific gravity } & \multicolumn{2}{|c|}{1.16} & 1.00 & 1.10 & \multicolumn{2}{|c|}{1.09} \\
\hline Component & MW & $\begin{array}{l}\text { Mass } \\
\text { insoluble } \\
\text { (kgs) }\end{array}$ & $\begin{array}{l}\text { Mass } \\
\text { soluble } \\
\text { (kgs) }\end{array}$ & $\begin{array}{l}\text { Mass } \\
(\mathrm{kgs})\end{array}$ & $\begin{array}{l}\text { Mass } \\
(\mathrm{kgs})\end{array}$ & $\begin{array}{l}\text { Mass } \\
\text { (kgs) }\end{array}$ & $\underline{M}$ \\
\hline $\mathrm{Ag}^{+}$ & 108 & $3.22 E+02$ & $2.93 E+01$ & $\cdots$ & $3.22 \mathrm{E}+02$ & $2.97 E+01$ & $2.78 E-05$ \\
\hline $\mathrm{Al}^{* 3}$ & 27 & $3.67 E+04$ & 0 & - & $3.66 E+04$ & $1.47 E+02$ & $5.49 E-04$ \\
\hline $\mathrm{AS}^{\cdot 5}$ & 75 & $3.48 E+02$ & $1.82 E+02$ & - & $3.52 E+02$ & $1.78 \mathrm{E}+02$ & $2.40 E-04$ \\
\hline$B^{\cdot 3}$ & 11 & $2.38 E+02$ & $8.13 E+01$ & -- & $2.39 E+02$ & $7.98 E+01$ & $7.33 E-04$ \\
\hline $\mathrm{Ba}^{+2}$ & 137 & $3.80 \mathrm{E}+2$ & $9.82 E+00$ & -- & $3.79 E+02$ & $1.10 \mathrm{E}+01$ & 8.14 E-06 \\
\hline $\mathrm{Be}^{+2}$ & 9 & $9.23 E+00$ & $7.17 \mathrm{E}-01$ & $\cdots$ & $9.21 E+00$ & 7.32 E-01 & 8.22 E-06 \\
\hline $\mathrm{Ca}^{+2}$ & 40 & $1.62 E+03$ & $4.21 E+01$ & -- & $1.61 E+03$ & $4.73 E+01$ & $1.19 \mathrm{E}-04$ \\
\hline $\mathrm{Cd}^{2}$ & 112 & $6.07 E+03$ & $1.80 E+01$ & -- & $6.05 E+03$ & $4.17 E+01$ & $3.76 E-05$ \\
\hline $\mathrm{CO}^{+3}$ & 59 & $7.81 E+02$ & $3.28 E+01$ & $\cdots$ & $7.79 E+02$ & $3.49 E+01$ & $5.98 \varepsilon-05$ \\
\hline $\mathrm{Cs}^{+(b)}$ & 134 & 0 & $3.50 E+02$ & -- & $1.05 E+00$ & $3.40 E+01$ & $2.56 E-05$ \\
\hline $\mathrm{Cr}^{.3}$ & 52 & $1.28 E+03$ & $4.97 E+03$ & $\cdots$ & $1.42 E+03$ & $4.83 E+03$ & 9.37 E-03 \\
\hline $\mathrm{Cu}^{+2}$ & 64 & $2.33 E+02$ & $1.04 E+01$ & -- & $2.32 E+02$ & $1.10 E+01$ & 1.74 E-05 \\
\hline $\mathrm{Fe}^{* 3}$ & 56 & $5.94 E+04$ & $8.53 E+01$ & $\cdots$ & $5.92 E+04$ & $3.20 E+02$ & $5.78 E-04$ \\
\hline $\mathrm{H}^{*}$ & 1 & 0 & 0 & -- & 0 & 0 & 0 \\
\hline$K^{*}$ & 39 & $2.88 E+03$ & $1.92 E+04$ & -- & $3.44 E+03$ & $1.86 E+04$ & 4.83 E-02 \\
\hline $\mathrm{Mg}^{* 2}$ & 24 & $4.63 E+02$ & $1.12 E+01$ & $-\cdot$ & $4.61 E+02$ & $1.27 E+01$ & 5.35 E-05 \\
\hline $\mathrm{Mo}^{.6}$ & 96 & $7.16 E+01$ & $4.59 E+02$ & $\cdots$ & $8.51 E+01$ & $4.46 E+02$ & $4.69 E-04$ \\
\hline $\mathrm{Na}^{*}$ & 23 & $5.76 E+04$ & $5.31 E+05$ & $3.11 E+03$ & $7.34 E+04$ & $5.18 E+05$ & $2.28 E+00$ \\
\hline $\mathrm{Ni}^{+3}$ & 59 & $3.43 E+03$ & $1.39 E+01$ & $-\cdot$ & $3.42 E+03$ & $2.72 E+01$ & $4.66 E-05$ \\
\hline
\end{tabular}


Tab7e 12-1. Cesium Ion Exchange, Neutralized Current Acid Waste, Resorcinol-Formaldehyde Resin, Major Process Stream Data. (2 sheets)

\begin{tabular}{|c|c|c|c|c|c|c|c|}
\hline \multicolumn{2}{|c|}{ Stream number } & \multicolumn{2}{|c|}{--} & 120 & 520 & \multicolumn{2}{|c|}{420} \\
\hline \multicolumn{2}{|c|}{ Description } & \multicolumn{2}{|c|}{ In tank } & \multirow{2}{*}{$\begin{array}{c}\begin{array}{c}\text { Solutions for } \\
\text { retrieval and } \\
\text { sludge } \\
\text { washing }\end{array} \\
\begin{array}{c}\text { Mass } \\
\text { (kgs) }\end{array}\end{array}$} & \multirow{2}{*}{$\begin{array}{l}\text { Sludge washed } \\
\text { solids } \\
\text { to HLW glass } \\
\begin{array}{c}\text { Mass } \\
\text { (kgs) }\end{array}\end{array}$} & \multicolumn{2}{|c|}{$\begin{array}{l}\text { sludge washed } \\
\text { supernate }\end{array}$} \\
\hline Component & MW & $\begin{array}{l}\text { Mass } \\
\text { insoluble } \\
\text { (kgs) }\end{array}$ & $\begin{array}{l}\text { Mass } \\
\text { soluble } \\
\text { (kgs) }\end{array}$ & & & $\begin{array}{l}\text { Mass } \\
\text { (kgs) }\end{array}$ & $\underline{M}$ \\
\hline $\mathrm{Pb}^{\cdot 4}$ & 207 & $4.83 E+02$ & $3.42 E+01$ & $\cdots$ & $4.82 E+02$ & $3.51 E+01$ & 1.71 E-05 \\
\hline $\begin{array}{l}\text { Rare } \\
\text { earths }{ }^{* 3}\end{array}$ & $\cdots$ & $4.55 E+03$ & $6.09 E+01$ & -- & $4.53 E+03$ & $7.73 E+01$ & - \\
\hline $\mathrm{Rh}^{+3}$ & 103 & $7.35 E+01$ & $1.07 \varepsilon+01$ & $\cdots$ & $7.53 E+01$ & $1.07 E+01$ & $1.05 E-05$ \\
\hline $\mathrm{Ru}^{+3}$ & 101 & $2.66 E+02$ & $2.43 E+01$ & -- & $2.66 E+02$ & $2.46 E+01$ & $2.46 E-05$ \\
\hline $\mathrm{Si}^{+4}$ & 28 & $3.19 E+03$ & $2.14 E+03$ & $\cdots$ & $3.24 E+03$ & $2.09 E+03$ & 7.35 E-03 \\
\hline $\mathrm{Th}^{+4}$ & 232 & $5.16 E+02$ & $1.98 E+01$ & -- & $5.15 E+02$ & $2.13 E+01$ & $9.26 E-06$ \\
\hline $\mathrm{Ti}^{+4}$ & 48 & $2.21 E+02$ & $4.59 E+00$ & -- & $2.20 E+02$ & $5.34 E+00$ & 1.12 E-05 \\
\hline $\mathrm{UO}_{2}{ }^{2}$ & 270 & $3.41 E+03$ & $5.28 E+03$ & $-\cdot$ & $3.55 E+03$ & $5.14 E+03$ & $1.92 E-03$ \\
\hline $\mathrm{Zn}^{\cdot 2}$ & 65 & $1.63 E+02$ & $4.33 E+01$ & $\cdots$ & $1.64 E+02$ & $4.27 E+01$ & $6.63 E-05$ \\
\hline $\mathrm{AlO}_{2}^{-}$ & 59 & 0 & $6.72 E+04$ & -- & $2.02 E+03$ & $6.52 E+04$ & 1.12 E-01 \\
\hline $\mathrm{Cl}^{-}$ & 35 & $9.77 E+01$ & $7.41 E+02$ & $\cdots$ & $1.20 E+02$ & $7.19 E+02$ & $2.08 E-03$ \\
\hline $\mathrm{CO}_{3-2}$ & 60 & $7.57 E+03$ & $3.44 E+04$ & -- & $8.57 E+03$ & $3.34 E+04$ & 5.62 E-02 \\
\hline$F^{-}$ & 19 & $1.42 E+03$ & $7.46 E+03$ & - & $1.64 E+03$ & $7.24 E+03$ & 3.85 E-02 \\
\hline $\mathrm{NO}_{2}{ }^{-}$ & 46 & $1.63 E+04$ & $1.27 E+05$ & $3.26 E+03$ & $2.01 E+04$ & $1.26 E+05$ & $2.78 E-01$ \\
\hline $\mathrm{NO}_{3}^{-}$ & 62 & $1.81 E+04$ & $3.76 E+05$ & -- & $2.93 E+04$ & $3.65 E+05$ & 5.94 E-01 \\
\hline $\mathrm{OH}^{-}$ & 17 & $1.66 E+05$ & $1.76 E+05$ & $1.20 E+03$ & $1.71 E+05$ & $1.73 E+05$ & $1.03 E+00$ \\
\hline $\mathrm{PO}_{4}^{-3}$ & 95 & $4.50 E+03$ & $4.54 E+04$ & -- & $5.84 E+03$ & $4.41 E+04$ & $4.68 E-02$ \\
\hline $\mathrm{SO}_{4}^{-2}$ & 96 & $1.00 E+04$ & $1.04 E+05$ & -- & $1.31 E+4$ & $1.01 E+05$ & 1.06 E-01 \\
\hline TOC & -- & $4.39 E+03$ & $8.24 E+03$ & $\cdots$ & $4.62 E+03$ & $8.01 E+03$ & $\cdots$ \\
\hline $\mathrm{MnO}_{2}$ & 87 & $2.77 E+03$ & $8.67 E+00$ & $\cdots$ & $2.76 E+03$ & $1.95 E+01$ & $2.26 E-05$ \\
\hline $2 \mathrm{rO}_{2}: 2 \mathrm{H}_{2} \mathrm{O}$ & 159 & $2.76 E+04$ & $6.39 E+01$ & $\cdots$ & $2.75 E+04$ & $1.72 E+02$ & 1.10 E-04 \\
\hline $\mathrm{H}_{2} \mathrm{O}$ & 18 & 0 & $6.54 E+06$ & $6.45 E+06$ & $3.64 E+06$ & $9.35 E+06$ & $5.25 E+01$ \\
\hline Total & -. & $4.43 E+05$ & $8.05 E+06$ & $6.46 E+06$ & $4.12 E+06$ & $1.08 E+07$ & -. \\
\hline
\end{tabular}

(a) Rate of waste volume only, does not including dilution water

(b) Includes all isotopes of cesium. 
Table 12-2. Cesium Ion Exchange, Neutralized Current Acid Waste, Resorcinol-Formaldehyde Resin, Major Process Stream Data. (2 sheets)

\begin{tabular}{|c|c|c|c|c|c|c|c|}
\hline \multicolumn{2}{|c|}{ Stream number } & \multicolumn{2}{|c|}{427} & 130 & 530 & \multicolumn{2}{|c|}{430} \\
\hline \multicolumn{2}{|c|}{ Description } & \multicolumn{2}{|c|}{$\begin{array}{c}\text { Pre-Cs-Ix evaporator } \\
\text { bottoms }\end{array}$} & $\begin{array}{l}\text { Pre-Cs-IX } \\
\text { evaporator } \\
\text { overheads }\end{array}$ & $\begin{array}{l}\text { Filtered } \\
\text { solids }\end{array}$ & \multicolumn{2}{|c|}{ Cs-IX column LLW feed } \\
\hline \multicolumn{2}{|c|}{$\begin{array}{l}\text { Temperature } \\
\left({ }^{\circ} \mathrm{C}\right)\end{array}$} & \multicolumn{2}{|c|}{--} & $-\cdot$ & -- & \multicolumn{2}{|c|}{25} \\
\hline \multicolumn{2}{|c|}{ Total volume $(L)$} & \multicolumn{2}{|c|}{$4.51 E+06$} & $5.39 E+06$ & -- & \multicolumn{2}{|c|}{$4.50 E+06$} \\
\hline \multicolumn{2}{|c|}{$\begin{array}{l}\text { Instantaneous } \\
\text { design flow rate } \\
\text { (L/min) }\end{array}$} & \multicolumn{2}{|c|}{108} & 120 & -- & \multicolumn{2}{|c|}{108} \\
\hline \multicolumn{2}{|c|}{$\begin{array}{l}\text { Total suspended } \\
\text { sol ids (ppm) }\end{array}$} & \multicolumn{2}{|c|}{ - } & 0 & $\cdots$ & \multicolumn{2}{|c|}{100} \\
\hline \multicolumn{2}{|c|}{ Specific gravity } & \multicolumn{2}{|c|}{1.20} & 1.00 & - & \multicolumn{2}{|c|}{1.21} \\
\hline Component & $M W$ & $\begin{array}{l}\text { mass } \\
\text { (kgs) }\end{array}$ & $\underline{M}$ & $\begin{array}{l}\text { mass } \\
\text { (kgs) }\end{array}$ & $\begin{array}{l}\text { mass } \\
\text { (kgs) }\end{array}$ & $\begin{array}{l}\text { mass } \\
\text { (kgs) }\end{array}$ & $\underline{M}$ \\
\hline $\mathrm{Ag}^{*}$ & 108 & $2.97 \mathrm{E}+01$ & $6.10 E-05$ & $\cdots$ & $1.29 E+00$ & $2.84 E+01$ & $5.85 E-05$ \\
\hline $\mathrm{Al}^{+3}$ & 27 & $1.47 \mathrm{E}+02$ & $1.21 E-03$ & $\cdots$ & $1.47 \mathrm{E}+02$ & 0 & 0 \\
\hline $\mathrm{As}^{.5}$ & 75 & $1.78 E+02$ & $5.26 E-04$ & - & $1.39 E+00$ & $1.77 \mathrm{E}+02$ & $5.23 E-04$ \\
\hline $\mathrm{B}^{+3}$ & 11 & $7.98 E+01$ & $1.61 E-03$ & - & $9.52 \mathrm{E}-01$ & $7.89 E+01$ & $1.59 E-03$ \\
\hline $\mathrm{Ba}^{+2}$ & 137 & $1.10 \mathrm{E}+01$ & 1.79 E-05 & -- & $1.52 \mathrm{E}+00$ & $9.53 E+00$ & $1.55 E-05$ \\
\hline$B e^{+2}$ & 9 & 7.32 E-01 & $1.80 E-05$ & $\therefore$ & $3.69 E-02$ & $6.95 E-01$ & $1.72 \varepsilon-05$ \\
\hline $\mathrm{Ca}^{+2}$ & 40 & $4.73 E+01$ & 2.62 E- 04 & $\cdots$ & $6.48 E+00$ & $4.08 E+01$ & $2.27 E-04$ \\
\hline $\mathrm{Cd}^{+2}$ & 112 & $4.17 E+01$ & $8.26 E-05$ & -- & $2.43 E+01$ & $1.75+01$ & $3.46 E-05$ \\
\hline $\mathrm{Co}^{+3}$ & 59 & $3.49 E+01$ & 1.31 E-04 & $\cdots$ & $3.12 E+D 0$ & $3.18 \mathrm{E}+01$ & $1.20 E-04$ \\
\hline $\mathrm{Cs}^{+(\theta)}$ & 134 & $3.40 E+02$ & $5.62 \mathrm{E}-04$ & $\cdots$ & 0 & $3.40 E+02$ & 5.63 E- 04 \\
\hline $\mathrm{Cr}+3$ & 52 & $4.83 E+03$ & $2.06 E-02$ & - & $5.12 E+00$ & $4.82 E+03$ & $2.06 \mathrm{E}-02$ \\
\hline $\mathrm{Cu}^{+2}$ & 64 & $1.10 E+01$ & 3.82 E-05 & -- & 9.32 E-01 & $1.01 \mathrm{E}+01$ & $3.50 E-05$ \\
\hline $\mathrm{Fe}^{\cdot 3}$ & 56 & $3.20 E+02$ & 1.27 E-03 & -- & $2.38 E+02$ & $8.27 E+01$ & $3.28 E-04$ \\
\hline $\mathrm{H}^{*}$ & 1 & 0 & 0 & $\cdots$ & 0 & 0 & 0 \\
\hline $\mathbf{K}^{+}$ & 39 & $1.86 E+04$ & 1.06 E-01 & -- & $1.15 \mathrm{E}+01$ & $1.86 E+04$ & 1.06 E-01 \\
\hline $\mathrm{Mg}^{+2}$ & 24 & $1.27 \mathrm{E}+01$ & 1.17 E- 04 & -- & $1.85 E+00$ & $1.09 E+01$ & $1.01 E-04$ \\
\hline $\mathrm{Mo}^{+6}$ & 96 & $4.46 \mathrm{E}+02$ & $1.03 \mathrm{E}-03$ & -- & 2.86 E-01 & $4.45 E+02$ & 1.03 E-03 \\
\hline $\mathrm{Na}^{+}$ & 23 & $5.18 E+05$ & $5.00 E+00$ & $\cdots$ & $2.30 E+02$ & $5.18 E+05$ & $5.01 E+00$ \\
\hline$N i^{+3}$ & 59 & $2.72 E+01$ & $1.02 \mathrm{E}-04$ & -- & $1.37 E+01$ & $1.35 E+01$ & 5.08 E-05 \\
\hline
\end{tabular}


Table 12-2. Cesium Ion Exchange, Neutralized Current Acid Waste, Resorcinol-Formaldehyde Resin, Major Process Stream Data. (2 sheets)

\begin{tabular}{|c|c|c|c|c|c|c|c|}
\hline \multicolumn{2}{|c|}{ Stream number } & \multicolumn{2}{|c|}{427} & 130 & 530 & \multicolumn{2}{|c|}{430} \\
\hline \multicolumn{2}{|c|}{ Description } & \multicolumn{2}{|c|}{$\begin{array}{c}\text { Pre-Cs-Ix evaporator } \\
\text { bottoms }\end{array}$} & \multirow{2}{*}{$\begin{array}{c}\begin{array}{c}\text { Pre-Cs-IX } \\
\text { evaporator } \\
\text { overheads }\end{array} \\
\begin{array}{c}\text { Mass } \\
\text { (kgs) }\end{array}\end{array}$} & \multirow{2}{*}{$\begin{array}{c}\begin{array}{c}\text { Filtered } \\
\text { solids }\end{array} \\
\begin{array}{c}\text { Mass } \\
\text { (kgs) }\end{array}\end{array}$} & \multicolumn{2}{|c|}{ Cs-IX column LLW feed } \\
\hline Component & MW & $\begin{array}{l}\text { Mass } \\
(\mathrm{kgs})\end{array}$ & $\underline{\mathrm{M}}$ & & & $\begin{array}{l}\text { Mass } \\
(\mathrm{kgs})\end{array}$ & $\underline{M}$ \\
\hline $\mathrm{Pb}^{* 4}$ & 207 & $3.51 E+01$ & 3.76 E-05 & -- & $1.93 E+00$ & $3.32 E+01$ & $3.56 E-05$ \\
\hline $\begin{array}{l}\text { Rare } \\
\text { earths } * 3\end{array}$ & -- & $7.73 E+01$ & - & $\rightarrow$ & $1.82 E+01$ & $5.91 E+01$ & - \\
\hline $\mathrm{Rh}^{+3}$ & 103 & $1.07 E+01$ & $2.30 E-05$ & $\cdots$ & $3.01 E-01$ & $1.04 E+01$ & $2.24 E-05$ \\
\hline $\mathrm{Ru}^{+3}$ & 101 & $2.46 E+01$ & $5.41 E-05$ & $\cdots$ & $1.06 E+00$ & $2.36 E+01$ & $5.19 E-05$ \\
\hline $\mathrm{Si}^{\cdot 4}$ & 28 & $2.09 E+03$ & $1.65 E-02$ & -- & $1.28 \mathrm{E}+01$ & $2.08 E+03$ & $1.65 \mathrm{E}-02$ \\
\hline $\mathrm{Th}^{+4}$ & 232 & $2.13 E+01$ & $2.03 E-05$ & $\cdots$ & $2.06 E+00$ & $1.92 E+01$ & 1.84 E-05 \\
\hline $\mathrm{Ti}^{* 4}$ & 48 & $5.34 E+00$ & $2.47 \mathrm{E}-05$ & -- & 8.84 E-01 & $4.45 E+00$ & 2.06 E-05 \\
\hline $\mathrm{UO}_{2} \cdot 2$ & 270 & $5.14 E+03$ & $4.22 \mathrm{E}-03$ & -- & $1.36 E+01$ & 5.12.E+03 & $4.22 E-03$ \\
\hline $2 n^{+2}$ & 65 & 4.27 E+01 & 1.45 E-04 & $-\cdot$ & $6.52 E-01$ & $4.20 E+01$ & $1.44 E-04$ \\
\hline $\mathrm{AlO}{ }_{2}^{-}$ & 59 & $6.52 E+04$ & $2.45 \mathrm{E}-01$ & -- & 0 & $6.52 E+04$ & $2.46 \mathrm{E}-01$ \\
\hline $\mathrm{Cl}^{\circ}$ & 35 & $7.19 E+02$ & $4.56 \mathrm{E}-03$ & -- & 3.91 E-01 & $7.19 E+02$ & $4.56 E-03$ \\
\hline $\mathrm{CO}_{3}^{-2}$ & 60 & $3.34 E+04$ & $1.23 E-01$ & -- & $3.03 E+01$ & $3.34 E+04$ & 1.24 E-01 \\
\hline$f^{-}$ & 19 & $7.24 E+03$ & $8.45 E-02$ & $-\cdot$ & $5.68 E+00$ & $7.24 E+03$ & 8.46 E-02 \\
\hline $\mathrm{NO}_{2}^{-}$ & 46 & $1.26 E+05$ & $6.09 \mathrm{E}-01$ & $\cdots$ & $6.52 E+01$ & $1.26 E+05$ & $6.10 E-01$ \\
\hline $\mathrm{NO}_{3}^{-}$ & 62 & $3.65 E+05$ & $1.30 E+00$ & -- & $7.24 E+01$ & $3.65 E+05$ & $1.31 E+00$ \\
\hline $\mathrm{OH}^{-}$ & 17 & $1.73 E+05$ & $2.25 E+00$ & - & $6.64 E+02$ & $1.72 E+05$ & $2.25 E+00$ \\
\hline $\mathrm{PO}_{4}^{-3}$ & 95 & $4.41 E+04$ & $1.03 E-01$ & - & $1.80 E+01$ & $4.40 E+04$ & $1.03 E-01$ \\
\hline $\mathrm{SO}_{4}^{-2}$ & 96 & $1.01 E+05$ & $2.33 E-01$ & $\cdots$ & $4.00 E+01$ & $1.01 E+05$ & 2.34 E-01 \\
\hline TOC & -- & $8.01 E+03$ & -- & $\cdots$ & $1.76 E+01$ & $7.99 E+03$ & $\cdots$ \\
\hline $\mathrm{MnO}_{2}$ & 87 & $1.95 E+01$ & $4.97 E-05$ & $-\cdot$ & $1.11 E+01$ & $8.41 E+00$ & $2.15 E-05$ \\
\hline $\mathrm{ZrO}_{2}: 2 \mathrm{H}_{2} \mathrm{O}$ & 159 & $1.72 E+02$ & $2.40 E-04$ & - & $1.10 E+02$ & $6.20 E+01$ & $8.66 \mathrm{E}-05$ \\
\hline $\mathrm{H}_{2} \mathrm{O}$ & 18 & $3.96 E+06$ & - & $5.39 E+06$ & 0 & $3.96 E+06$ & $\cdots$ \\
\hline Total & -- & $5.43 E+06$ & $\cdots$ & $5.39 E+06$ & $1.77 E+03$ & $5.43 E+06$ & $\cdots$ \\
\hline
\end{tabular}

(a) Includes all isotopes of cesium. 
Table 12-3. Cesium Ion Exchange, Neutralized Current Acid Waste, Resorcinol-Formaldehyde Resin, Major

Process Stream Data. (2 sheets)

\begin{tabular}{|c|c|c|c|c|c|c|c|}
\hline \multicolumn{2}{|c|}{ Stream number } & \multicolumn{2}{|c|}{440} & 140 & 545 & \multicolumn{2}{|c|}{320} \\
\hline \multicolumn{2}{|c|}{ Description } & \multicolumn{2}{|c|}{ LLW column effluent } & $\begin{array}{l}\text { Post load } \\
\text { water wash }\end{array}$ & $\begin{array}{l}\text { Post load } \\
\text { wash effluent }\end{array}$ & \multicolumn{2}{|c|}{ Elution solution } \\
\hline \multicolumn{2}{|c|}{$\begin{array}{l}\text { Temperature } \\
\left({ }^{\circ} \mathrm{C}\right)\end{array}$} & \multicolumn{2}{|c|}{25} & 25 & 25 & \multicolumn{2}{|c|}{25} \\
\hline \multicolumn{2}{|c|}{ Total volume $(L)$} & \multicolumn{2}{|c|}{$4.50 E+06$} & $3.90 E+04$ & $3.90 E+04$ & \multicolumn{2}{|c|}{$5.20 E+05$} \\
\hline \multicolumn{2}{|c|}{$\begin{array}{l}\text { Instantaneous } \\
\text { design flow rate } \\
\text { (L/min) }\end{array}$} & \multicolumn{2}{|c|}{108} & $200^{(a)}$ & $200^{(a)}$ & \multicolumn{2}{|c|}{$100^{(3)}$} \\
\hline \multicolumn{2}{|c|}{$\begin{array}{l}\text { Total suspended } \\
\text { solids (ppm) }\end{array}$} & \multicolumn{2}{|c|}{-} & 0 & 0 & \multicolumn{2}{|c|}{0} \\
\hline \multicolumn{2}{|c|}{ Specific gravity } & \multicolumn{2}{|c|}{--} & 1.00 & 1.00 & \multicolumn{2}{|c|}{1.01} \\
\hline Component & MW & $\begin{array}{l}\text { Mass } \\
\text { (kgs) }\end{array}$ & $\underline{M}$ & $\begin{array}{l}\text { Mass } \\
\text { (kgs) }\end{array}$ & $\begin{array}{l}\text { Mass } \\
\text { (kgs) }\end{array}$ & $\begin{array}{l}\text { Mass } \\
(\mathrm{kgs})\end{array}$ & $\underline{M}$ \\
\hline $\mathrm{Ag}^{\circ}$ & 108 & $2.84 E+01$ & $5.85 E-05$ & $\cdots$ & $\cdots$ & -- & -- \\
\hline$A l^{\circ}$ & 27 & 0 & 0 & $\cdots$ & - & + & -- \\
\hline $\mathrm{As}^{-5}$ & 75 & $1.77 \mathrm{E}+02$ & $5.23 E-04$ & -- & -- & $\cdots$ & -- \\
\hline $\mathrm{B}^{+3}$ & 11 & $7.89 E+01$ & $1.59 E-03$ & -- & 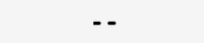 & -- & -- \\
\hline $\mathrm{Ba}^{\cdot 2}$ & 137 & $9.53 E+00$ & $1.55 E-05$ & $-\cdot$ & -- & -- & $\cdots$ \\
\hline $\mathrm{Be}^{.2}$ & 9 & $6.95 E-01$ & 1.72 E-05 & -- & -- & -- & -- \\
\hline $\mathrm{Ca}^{22}$ & 40 & $4.08 E+01$ & 2.27 E-04 & $-\cdot$ & -- & -- & - \\
\hline $\mathrm{Cd}^{+2}$ & 112 & $1.75 E+01$ & $3.46 E-05$ & $\cdots$ & $\cdots$ & -- & -. \\
\hline $\mathrm{CO}^{.3}$ & 59 & $3.18 E+01$ & $1.20 E-04$ & - &.- & $-\cdot$ & -. \\
\hline $\mathrm{Cs}^{+(b)}$ & 134 & $4.19 E-02$ & $6.95 E-08$ & $\rightarrow$ & -- & -- & $\cdots$ \\
\hline $\mathrm{Cr}^{+3}$ & 52 & $4.82 E+03$ & 2.06 E-02 & - & -- & .. & -- \\
\hline $\mathrm{Cu}^{22}$ & 64 & $1.01 E+01$ & $3.50 E-05$ & - & -- & -- & $\cdots$ \\
\hline $\mathrm{Fe}^{-3}$ & 56 & $8.27 E+01$ & 3.28 E-04 & -- & -- & - - & - - \\
\hline $\mathrm{H}^{+}$ & 1 & 0 & 0 & $-\infty$ & -- & $2.60 E+02$ & 5.00 E- 01 \\
\hline$K^{*}$ & 39 & $1.85 E+04$ & 1.06 E-01 & -- & -- & -- & $-\cdot$ \\
\hline $\mathrm{Mg}^{+2}$ & 24 & $1.09 E+01$ & $1.01 E-04$ & -- & -- & - & -- \\
\hline $\mathrm{Mo}^{+6}$ & 96 & $4.45 E+05$ & 1.03 E-03 & -. & -- & $\cdots$ & -- \\
\hline $\mathrm{Na}^{+}$ & 23 & $5.18 E+05$ & $5.01 E+00$ & -- & -- & -. & -- \\
\hline $\mathrm{Ni}^{+3}$ & 59 & $1.35 E+01$ & $5.08 \mathrm{E}-05$ & -- & -- & - - & - \\
\hline
\end{tabular}


Table 12-3. Cesium Ion Exchange, Neutralized Current Acid Waste, Resorcinol-Formaldehyde Resin, Major

Process Stream Data. (2 sheets)

\begin{tabular}{|c|c|c|c|c|c|c|c|}
\hline \multicolumn{2}{|c|}{ stream number } & \multicolumn{2}{|c|}{440} & 140 & 545 & \multicolumn{2}{|c|}{320} \\
\hline \multicolumn{2}{|c|}{ Description } & \multicolumn{2}{|c|}{ LLW column effluent } & \multirow{2}{*}{$\begin{array}{c}\begin{array}{c}\text { Post load } \\
\text { water wash }\end{array} \\
\begin{array}{c}\text { Mass } \\
\text { (kgs) }\end{array}\end{array}$} & \multirow{2}{*}{ 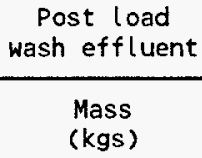 } & \multicolumn{2}{|c|}{ Elution solution } \\
\hline Component & MW & $\begin{array}{l}\text { Mass } \\
\text { (kgs) }\end{array}$ & $\underline{M}$ & & & $\begin{array}{l}\text { Mass } \\
\text { (kgs) }\end{array}$ & $\underline{M}$ \\
\hline $\mathrm{Pb}^{+4}$ & 207 & $3.32 E+01$ & $3.56 E-05$ & -- & -- & $\cdots$ & -- \\
\hline $\begin{array}{l}\text { Rare } \\
\text { Earths }+3\end{array}$ & - & $5.91 E+01$ & -- & $\cdots$ & -- & $-\cdot$ & -- \\
\hline $\mathrm{Rh}^{-3}$ & 103 & $1.04 E+01$ & 2.24 E-05 & -- & $\cdots$ & $\cdots$ & $\cdots$ \\
\hline $\mathrm{Ru}^{* 3}$ & 101 & $2.36 E+01$ & 5.19 E- 05 & - & $\cdots$ & $\cdots$ & - \\
\hline$S i^{+4}$ & 28 & $2.08 E+03$ & $1.65 \varepsilon-02$ & -. & -. & -- & -- \\
\hline $\mathrm{Th}^{+4}$ & 232 & $1.92 \mathrm{E}+01$ & $1.84 \varepsilon-05$ & $\cdots$ & -- & $\cdots$ & - \\
\hline $\mathrm{Ti}^{+4}$ & 48 & $4.45 E+\infty 0$ & 2.06 E-05 & - & -- & $\cdots$ & -- \\
\hline $\mathrm{UO}_{2}{ }^{+2}$ & 270 & $5.12 E+03$ & 4.22 E-03 & $\cdots$ & -- & $\cdots$ & - \\
\hline $\mathrm{Zn}^{+2}$ & 65 & $4.20 E+01$ & 1.44 E-04 & $\cdots$ & -- & -- & -- \\
\hline $\mathrm{AlO}{ }_{2}^{-}$ & 59 & $6.52 E+04$ & $2.46 \mathrm{E}-01$ & -. & -. & $\cdots$ & -- \\
\hline $\mathrm{Cl}^{-}$ & 35 & $7.19 E+02$ & $4.56 E-03$ & $\cdots$ & -- & -- & - - \\
\hline $\mathrm{CO}_{3}^{-2}$ & 60 & $3.34 E+04$ & 1.24 E-01 & -- & - & $\cdots$ & -- \\
\hline $\mathrm{F}^{-}$ & 19 & $7.24 E+03$ & 8.46 E-02 & -- & $\cdots$ & $\cdots$ & $\cdots$ \\
\hline $\mathrm{NO}_{2}^{-}$ & 46 & $1.26 E+05$ & $6.10 \mathrm{E}-02$ & - & $\cdots$ & $\cdots$ & - \\
\hline $\mathrm{NO}_{3}^{-}$ & 62 & $3.65 E+05$ & $1.31 E+\infty 0$ & -- & -. & $1.61 E+04$ & 5.00 E-01 \\
\hline $\mathrm{OH}^{-}$ & 17 & $1.72 E+05$ & $2.25 E+00$ & - & -- & $\cdots$ & -- \\
\hline $\mathrm{PO}_{4}^{-3}$ & 95 & $4.40 E+04$ & $1.03 E-01$ & -. & -. & -- & - \\
\hline $\mathrm{SO}_{4}^{-2}$ & 96 & $1.01 E+05$ & 2.34 E-01 & -- & -- & -- & $\cdots$ \\
\hline TOC & -- & $7.99 E+03$ & -- & $\cdots$ & $\cdots$ & -- & - \\
\hline $\mathrm{MnO}_{2}$ & 87 & $8.41 E+00$ & 2.15 E-05 & -- & -- & -- & -- \\
\hline $\mathrm{ZrO}_{2}: 2 \mathrm{H}_{2} \mathrm{O}$ & 159 & $6.20 E+01$ & $8.66 E-0.5$ & $\cdots$ & -- & -- & -- \\
\hline $\mathrm{H}_{2} \mathrm{O}$ & 18 & $3.96 E+06$ & -- & $3.90 E+04$ & $3.90 E+04$ & $5.11 E+05$ & -- \\
\hline Total & - & $5.43 E+06$ & -. & $3.90 E+04$ & $3.90 E+04$ & $5.27 \mathrm{E}+05$ & - \\
\hline
\end{tabular}

(a) Intermittent process stream.

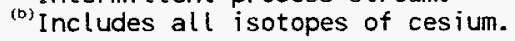


Table 12-4. Cesium Ion Exchange, Neutralized Current Acid Waste, Resorcinol-Formaldehyde Resin, Major

Process Stream Data. (2 sheets)

\begin{tabular}{|c|c|c|c|c|c|c|}
\hline \multicolumn{2}{|c|}{ Stream number } & \multicolumn{2}{|c|}{540} & 150 & 550 & 447 \\
\hline \multicolumn{2}{|c|}{ Description } & \multicolumn{2}{|c|}{ Eluate } & $\begin{array}{l}\text { Post elution } \\
\text { water wash }\end{array}$ & $\begin{array}{c}\text { Post elution water } \\
\text { wash, column } \\
\text { effluent, HLW } \\
\text { portion }\end{array}$ & $\begin{array}{c}\text { Post elution water } \\
\text { wash, column } \\
\text { effluent, LLW } \\
\text { portion }\end{array}$ \\
\hline \multicolumn{2}{|c|}{$\begin{array}{c}\text { temperature } \\
\left({ }^{\circ} \mathrm{C}\right)\end{array}$} & \multicolumn{2}{|c|}{25} & 25 & 25 & 25 \\
\hline \multicolumn{2}{|c|}{ Total volume (L) } & \multicolumn{2}{|c|}{$5.20 E+05$} & $5.20 E+04$ & $2.60 E+04$ & $2.60 E+04$ \\
\hline \multicolumn{2}{|c|}{$\begin{array}{l}\text { Instantaneous } \\
\text { design flow rate } \\
(\mathrm{L} / \mathrm{min})\end{array}$} & \multicolumn{2}{|c|}{$100^{(a)}$} & $200^{(a)}$ & $200^{(a)}$ & $200^{(a)}$ \\
\hline \multicolumn{2}{|c|}{$\begin{array}{l}\text { Total suspended } \\
\text { solids (ppm) }\end{array}$} & \multicolumn{2}{|c|}{0} & 0 & 0 & 0 \\
\hline \multicolumn{2}{|c|}{ Specific gravity } & \multicolumn{2}{|c|}{1.02} & 1.00 & 1.00 & 1.00 \\
\hline Component & MW & $\begin{array}{l}\text { mass } \\
\text { (kgs) }\end{array}$ & $\underline{M}$ & $\begin{array}{l}\text { mass } \\
\text { (kgs) }\end{array}$ & $\begin{array}{l}\text { Imass } \\
\text { (kgs) }\end{array}$ & $\begin{array}{l}\text { mass } \\
\text { (kgs) }\end{array}$ \\
\hline $\mathrm{Ag}^{*}$ & 108 & -- & -- & $=-$ & $\cdots$ & -- \\
\hline $\mathrm{Al}^{* 3}$ & 27 & -- & -- & -- & -- & -- \\
\hline $\mathrm{As}^{+5}$ & 75 & $\cdots$ & -- & -- & -- & -- \\
\hline $\mathrm{B}^{+3}$ & 11 & -- & $\cdots$ & + & -- & $\cdots$ \\
\hline $\mathrm{Ba} \cdot 2$ & 137 & + & -- & -- & -- & -- \\
\hline$B e^{* 2}$ & 9 & $\cdots$ & -- & -- & $\cdots$ & - \\
\hline $\mathrm{Ca}^{* 2}$ & 40 & $=$ & -- & - & -- & -- \\
\hline $\mathrm{Cd}^{+2}$ & 112 & -- & -- & +- & -- & $\cdots$ \\
\hline $\mathrm{Co}^{+3}$ & 59 & -- & -- & $\rightarrow$ & -- & -- \\
\hline $\mathrm{Cs}^{+(b)}$ & 134 & $3.40 E+02$ & $4.88 E-03$ & -- & -- & -- \\
\hline $\mathrm{Cr}^{+3}$ & 52 & -- & $\cdots$ & -- & -- & - \\
\hline $\mathrm{Cu}^{+2}$ & 64 & -- & -- & $\cdots$ & -- & -- \\
\hline $\mathrm{Fe}^{+3}$ & 56 & -- & -- & -- & $\cdots$ & -- \\
\hline $\mathrm{H}^{+}$ & 1 & $2.19 \mathrm{E}+02$ & $4.21 E-03$ & -- & -- & -- \\
\hline $\mathrm{K}^{+}$ & 39 & $\cdots$ & -- & - & -- & -- \\
\hline $\mathrm{Mg}^{+2}$ & 24 & -- & -- & $-\cdot$ & -- & -- \\
\hline $\mathrm{Mo}^{+6}$ & 96 & -- & -- & -- & $\cdots$ & -- \\
\hline $\mathrm{Na}^{+}$ & 23 & $8.81 E+02$ & $7.37 \mathrm{E}-02$ & $\cdots$ & $\cdots$ & $=$ \\
\hline $\mathrm{Ni}^{+3}$ & 59 & - & $\cdots$ & $\cdots$ & -- & - \\
\hline
\end{tabular}


Table 12-4. Cesium Ion Exchange, Neutralized Current Acid Waste, Resorcinol-Formaldehyde Resin, Major

Process Stream Data. (2 sheets)

\begin{tabular}{|c|c|c|c|c|c|c|}
\hline \multicolumn{2}{|c|}{ Stream number } & \multicolumn{2}{|c|}{540} & 150 & 550 & 447 \\
\hline \multicolumn{2}{|c|}{ Description } & \multicolumn{2}{|c|}{ Eluate } & $\begin{array}{l}\text { Post elution } \\
\text { water wash }\end{array}$ & $\begin{array}{c}\text { Post elution water } \\
\text { wash, column } \\
\text { effluent, HLW } \\
\text { portion }\end{array}$ & $\begin{array}{c}\text { Post elution water } \\
\text { wash, column } \\
\text { effluent, LLW } \\
\text { portion }\end{array}$ \\
\hline Component & MW & $\begin{array}{l}\text { Mass } \\
\text { (kgs) }\end{array}$ & $\underline{M}$ & $\begin{array}{l}\text { mass } \\
\text { (kgs) }\end{array}$ & $\begin{array}{l}\text { mass } \\
\text { (kgs) }\end{array}$ & $\begin{array}{l}\text { mass } \\
\text { (kgs) }\end{array}$ \\
\hline $\mathrm{Pb}^{-4}$ & 207 & -- & -- & -- & $\cdots$ & -- \\
\hline $\begin{array}{l}\text { Rare } \\
\text { Earths }{ }^{* 3}\end{array}$ & -- & -- & -- & -- & $\cdots$ & $\ldots$ \\
\hline $\mathrm{Rh}^{* 3}$ & 103 & -- & -- & -- & $=-$ & - \\
\hline $\mathrm{Ru}^{+3}$ & 101 & $\cdots$ & $\cdots$ & -- & -- & -- \\
\hline $\mathrm{Si}^{-4}$ & 28 & -- & $\cdots$ & -- & - & -- \\
\hline $\mathrm{Th}^{* 4}$ & 232 & -- & $\cdots$ & $\rightarrow$ & -- & -- \\
\hline$T i^{* 4}$ & 48 & -- & $\cdots$ & -- & $\cdots$ & -- \\
\hline $\mathrm{UO}_{2}^{+2}$ & 270 & $\cdots$ & -- & -- & $\cdots$ & -- \\
\hline $2 n^{-2}$ & 65 & - & -- & -- & -- & - \\
\hline $\mathrm{AlO}_{2}^{-}$ & 59 & -- & -- & -- & -- & -- \\
\hline $\mathrm{Cl}^{\circ}$ & 35 & - & $\cdots$ & - & -- & -- \\
\hline $\mathrm{CO}_{3}^{-2}$ & 60 & $\infty$ & $\cdots$ & - & -- & -- \\
\hline $\mathrm{F}^{-}$ & 19 & -- & $-\infty$ & - & $\cdots$ & $\cdots$ \\
\hline $\mathrm{NO}_{2}^{-}$ & 46 & $=$ & $\cdots$ & $\cdots$ & $\cdots$ & $\cdots$ \\
\hline $\mathrm{NO}_{3}^{-}$ & 62 & $1.61 E+04$ & $5.00 E-01$ & -- & -- & -- \\
\hline $\mathrm{OH}^{-}$ & 17 & -- & $\cdots$ & - & $\cdots$ & -- \\
\hline $\mathrm{PO}_{4}^{-3}$ & 95 & -- & -- & $=$ & $\cdots$ & -- \\
\hline $\mathrm{SO}_{4}^{-2}$ & 96 & $\cdots$ & - & $\cdots$ & $-\infty$ & -- \\
\hline TOC & - & -- & -- & $\cdots$ & $-\cdot$ & -- \\
\hline $\mathrm{MnO}_{2}$ & 87 & $\cdots$ & $\cdots$ & . - - & -- & -- \\
\hline $2 \mathrm{rO}_{2}: 2 \mathrm{H}_{2} \mathrm{O}$ & 159 & -- & -- & -- & -- & - \\
\hline $\mathrm{H}_{2} \mathrm{O}$ & 18 & $5.11 E+05$ & -- & $5.20 E+04$ & $2.60 E+04$ & $2.60 E+04$ \\
\hline Total & -- & $5.27 E+05$ & -. & $5.20 E+04$ & $2.60 E+04$ & $2.60 E+04$ \\
\hline
\end{tabular}


Table 12-5. Cesium Ion Exchange, Neutralized Current Acid Waste, Resorcinol-Formaldehyde Major

Process Stream Data. (2 sheets)

\begin{tabular}{|c|c|c|c|c|c|}
\hline \multicolumn{2}{|c|}{ Stream number } & \multicolumn{2}{|c|}{231} & 441 & 233 \\
\hline \multicolumn{2}{|c|}{ Description } & \multicolumn{2}{|c|}{ First regeneration } & $\begin{array}{c}\text { First regeneration } \\
\text { effluent }\end{array}$ & $\begin{array}{l}\text { Second } \\
\text { regeneration }\end{array}$ \\
\hline \multicolumn{2}{|c|}{$\begin{array}{c}\text { Temperature } \\
\left({ }^{\circ} \mathrm{C}\right)\end{array}$} & \multicolumn{2}{|c|}{25} & 25 & 25 \\
\hline \multicolumn{2}{|c|}{ Total volume (L) } & \multicolumn{2}{|c|}{$1.04 E+05$} & $1.05 E+05$ & $7.80 E+04$ \\
\hline \multicolumn{2}{|c|}{$\begin{array}{l}\text { Instantaneous } \\
\text { design flow rate } \\
(\mathrm{L} / \mathrm{min})\end{array}$} & \multicolumn{2}{|c|}{$100^{(a)}$} & $101^{(a)}$ & $100^{(a)}$ \\
\hline \multicolumn{2}{|c|}{$\begin{array}{l}\text { Total suspended } \\
\text { solids (ppm) }\end{array}$} & \multicolumn{2}{|c|}{$-\cdot$} & 200 &.$^{--}$ \\
\hline \multicolumn{2}{|c|}{ Specific gravity } & \multicolumn{2}{|c|}{1.02} & 1.00 & 9.05 \\
\hline Component & MW & \multicolumn{2}{|l|}{$\begin{array}{l}\text { mass } \\
\text { (kgs) }\end{array}$} & $\begin{array}{l}\text { mass } \\
\text { (kgs) }\end{array}$ & $\begin{array}{l}\text { mass } \\
\text { (kgs) }\end{array}$ \\
\hline $\mathrm{Ag}^{+}$ & 108 & - & - & $\cdots$ & - \\
\hline $\mathrm{Al}^{* 3}$ & 27 & -- & -- & $\cdots$ & $\cdots$ \\
\hline$A S^{.5}$ & 75 & -- & -- & -- & $\cdots$ \\
\hline$B^{+3}$ & 11 & -- & - & - & -- \\
\hline $\mathrm{Ba}^{+2}$ & 137 & $\cdots$ & -- & -- & $\cdots$ \\
\hline$B e^{+2}$ & 9 & -- & -- & -- & $\cdots$ \\
\hline $\mathrm{Ca}^{* 2}$ & 40 & - & -- & - & -- \\
\hline $\mathrm{Cd}^{+2}$ & 112 & $\cdots$ & -- & -- & -- \\
\hline $\mathrm{Co}^{.3}$ & 59 & - & -- & -- & - \\
\hline$C s^{*(b)}$ & 134 & -- & -- & -- & -- \\
\hline $\mathrm{Cr}^{+3}$ & 52 & - & $\cdots$ & -- & -- \\
\hline $\mathrm{Cu}^{+2}$ & 64 & -- & -- & -- & -- \\
\hline $\mathrm{Fe}^{+3}$ & 56 & $\cdots$ & -- & - & -- \\
\hline $\mathrm{H}^{\circ}$ & 1 & -- & - & -- & - \\
\hline $\mathrm{K}$ & 39 & - & - & - & -- \\
\hline $\mathrm{Mg}^{+2}$ & 24 & -- & -- & - & -- \\
\hline $\mathrm{Mo}^{+6}$ & 96 & -- & -- & $\cdots$ & -- \\
\hline $\mathrm{Na}^{*}$ & 23 & $1.20 E+03$ & 5.00 E-01 & $1.08 E+03$ & $3.59 E+03$ \\
\hline $\mathrm{Ni}^{+3}$ & 59 & $\cdots$ & $\cdots$ & $\cdots$ & $\cdots$ \\
\hline
\end{tabular}


Table 12-5. Cesium Ion Exchange, Neutralized Current Acid Waste, Resorcinol-Formaldehyde Resin, Major

Process Stream Data. (2 sheets)

\begin{tabular}{|c|c|c|c|c|c|}
\hline \multicolumn{2}{|c|}{ Stream number } & \multicolumn{2}{|c|}{231} & 441 & 233 \\
\hline \multicolumn{2}{|c|}{ Description } & \multicolumn{2}{|c|}{ First Regeneration } & $\begin{array}{c}\text { First Regeneration } \\
\text { Effluent }\end{array}$ & $\begin{array}{l}\text { Second } \\
\text { Regeneration }\end{array}$ \\
\hline Component & $M W$ & $\begin{array}{l}\text { Mass } \\
\text { (kgs) }\end{array}$ & $\underline{\mathbf{M}}$ & $\begin{array}{l}\text { Mass } \\
(\mathrm{kgs})\end{array}$ & $\begin{array}{l}\text { mass } \\
\text { (kgs) }\end{array}$ \\
\hline $\mathrm{Pb}^{+4}$ & 207 & -- & $\cdots$ & -- & -- \\
\hline $\begin{array}{l}\text { Rare } \\
\text { Earths }{ }^{+3}\end{array}$ & -- & - & -- & $\cdots$ & -- \\
\hline $\mathrm{Rh}^{* 3}$ & 103 & -- & -- & -- & -- \\
\hline $\mathrm{Ru}^{* 3}$ & 101. & -- & $-\cdot$ & -- & -- \\
\hline $\mathrm{Si}^{+4}$ & 28 & -- & -- & -- & -- \\
\hline$T h \cdot 4$ & 232 & -- & $\cdots$ & -- & $\cdots$ \\
\hline $\mathrm{Ti}^{+4}$ & 48 & $\cdots$ & $-\cdot$ & -- & -- \\
\hline $\mathrm{UO}_{2}{ }^{2}$ & 270 & -- & -- & -- & -- \\
\hline $\mathrm{Zn}^{+2}$ & 65 & -- & $-\cdot$ & -- & -- \\
\hline $\mathrm{AlO}_{2}^{-}$ & 59 & - & -- & -- & -- \\
\hline $\mathrm{Cl}^{-}$ & 35 & -- & $-\cdot$ & -- & -- \\
\hline $\mathrm{CO}_{3-2}$ & 60 & - & -- & -- & -- \\
\hline $\mathrm{F}^{-}$ & 19 & - & -- & -- & -- \\
\hline $\mathrm{NO}_{2}^{-}$ & 46 & - & -- & -- & $\cdots$ \\
\hline $\mathrm{NO}_{3}^{-}$ & 62 & -- & $\cdot-$ & -- & -- \\
\hline $\mathrm{OH}^{-}$ & 17 & $8.84 E+02$ & $5.00 E-01$ & $1.90 \mathrm{E}+02$ & $2.65 E+03$ \\
\hline $\mathrm{PO}_{4}^{-3}$ & 95 & $\cdots$ & $\cdots$ & $\cdots$ & $-\cdot$ \\
\hline $\mathrm{SO}_{4}^{-2}$ & 96 & -- & -- & -- & -- \\
\hline TOC & -- & -- & -- & -- & - \\
\hline $\mathrm{MnO}_{2}$ & 87 & - & -- & -- & -- \\
\hline $\mathrm{ZrO}_{2}: 2 \mathrm{H}_{2} \mathrm{O}$ & 159 & -- & -- & -- & -- \\
\hline $\mathrm{H}_{2} \mathrm{O}$ & 18 & $1.04 E+05$ & $\cdots$ & $1.05 E+05$ & $7.57 E+04$ \\
\hline Total & -- & $1.06 E+05$ & - & $1.06 E+05$ & $8.20 E+04$ \\
\hline
\end{tabular}

(a) Intermittent process stream

(b) Includes all isotopes of cesium. 
Table 12-6. Cesium Ion Exchange, Neutŕalized Current Acid Waste, Resorcinol-Formaldehyde Resin, Major Process Stream Data. (2 sheets)

\begin{tabular}{|c|c|c|c|c|c|c|}
\hline \multicolumn{2}{|c|}{ Stream number } & \multicolumn{2}{|c|}{443} & \multicolumn{2}{|c|}{455} & 166 \\
\hline \multicolumn{2}{|c|}{ Description } & \multicolumn{2}{|c|}{$\begin{array}{c}\text { Second regeneration } \\
\text { effluent }\end{array}$} & \multicolumn{2}{|c|}{ Post Cs-IX evaporator LLW feed } & $\begin{array}{l}\text { Post Cs-IX evapo- } \\
\text { rator overheads }\end{array}$ \\
\hline \multicolumn{2}{|c|}{$\begin{array}{c}\text { Temperature } \\
\left({ }^{\circ} \mathrm{C}\right)\end{array}$} & \multicolumn{2}{|c|}{25} & & & \\
\hline \multicolumn{2}{|c|}{ Total volume (L) } & \multicolumn{2}{|c|}{$7.80 E+04$} & \multicolumn{2}{|c|}{$4.75 E+06$} & $2.47 E+06$ \\
\hline \multicolumn{2}{|c|}{$\begin{array}{l}\text { Instantaneous } \\
\text { design flow rate } \\
(L / \mathrm{min})\end{array}$} & \multicolumn{2}{|c|}{$100^{(a)}$} & \multicolumn{2}{|c|}{106} & 55 \\
\hline \multicolumn{2}{|c|}{$\begin{array}{l}\text { Total suspended } \\
\text { solids (ppm) }\end{array}$} & \multicolumn{2}{|c|}{$-\cdot$} & \multicolumn{2}{|c|}{--} & -- \\
\hline \multicolumn{2}{|c|}{ Specific gravity } & \multicolumn{2}{|c|}{1.04} & \multicolumn{2}{|c|}{1.16} & 1.00 \\
\hline Component & MW & $\begin{array}{l}\text { Mass } \\
\text { (kgs) }\end{array}$ & $\underline{M}$ & $\begin{array}{l}\text { Mass } \\
\text { (kgs) }\end{array}$ & M & $\begin{array}{l}\text { Mass } \\
\text { (kgs) }\end{array}$ \\
\hline $\mathrm{Ag}^{\circ}$ & 108 & -- & $\cdots$ & $2.84 E+01$ & 5.54 E-05 & -- \\
\hline $\mathrm{Al}^{\cdot 3}$ & 27 & $\cdots$ & -- & 0 & 0 & $\cdots$ \\
\hline $\mathrm{As}^{* 5}$ & 75 & $\cdots$ & -- & $1.77 \mathrm{E}+02$ & $4.96 E-04$ & $\cdots$ \\
\hline $\mathrm{B}^{+3}$ & 11 & -- & - & $7.89 E+01$ & $1.51 E-03$ & -- \\
\hline $\mathrm{Ba}^{* 2}$ & 137 & -- & -- & $9.53 E+00$ & 1.46 E-05 & -- \\
\hline $\mathrm{Be}^{.2}$ & 9 & -- & -- & $6.95 \mathrm{E}-01$ & 1.83 E-05 & -- \\
\hline $\mathrm{Ca}^{.2}$ & 40 & -- & $-\cdot$ & $4.08 E+01$ & 2.15 E-04 & -- \\
\hline $\mathrm{Cd}^{+2}$ & 112 & -- & $-\cdot$ & $1.75 E+01$ & 3.28 E-05 & -- \\
\hline $\mathrm{Co}^{+3}$ & 59 & -- & -- & $3.18 E+01$ & 1.14 E-04 & -- \\
\hline $\mathrm{Cs}^{+(b)}$ & 134 & -- & -- & $4.19 E-02$ & $6.58 E-08$ & -- \\
\hline $\mathrm{Cr}^{* 3}$ & 52 & -- & -- & $4.82 E+03$ & 1.95 E-02 & -- \\
\hline $\mathrm{Cu}^{+2}$ & 64 & -. & -- & $1.01 E+01$ & 3.22 E-05 & -- \\
\hline $\mathrm{Fe}^{+3}$ & 56 & $\cdots$ & $-\cdot$ & $8.27 E+01$ & 3.11 E-04 & -- \\
\hline $\mathrm{H}^{*}$ & 1 & -- & -- & 0 & 0 & -- \\
\hline $\mathrm{K}^{+}$ & 39 & $-\cdot$ & $\cdots$ & $1.85 E+04$ & $1.01 E-01$ & -- \\
\hline $\mathrm{Mg}^{+2}$ & 24 & $\cdots$ & -- & $1.09 E+01$ & $9.53 E-05$ & -- \\
\hline $\mathrm{Mo}^{+6}$ & 96 & -- & -- & $4.45 E+02$ & 9.76 E-04 & -- \\
\hline $\mathrm{Na}^{+}$ & 23 & $3.59 E+03$ & $2.00 E+00$ & $5.23 E+05$ & $4.78 E+00$ & -- \\
\hline $\mathrm{Ni}^{+3}$ & 59 & -- & -- & $1.35 E+01$ & 4.81 E-05 & -- \\
\hline
\end{tabular}


Table 12-6. Cesium Ion Exchange, Neutralized Current Acid Waste, Resorcinol-Formaldehyde Resin, Major Process Stream Data. (2 sheets)

\begin{tabular}{|c|c|c|c|c|c|c|}
\hline \multicolumn{2}{|c|}{ Stream number } & \multicolumn{2}{|c|}{443} & \multicolumn{2}{|c|}{455} & 166 \\
\hline \multicolumn{2}{|c|}{ Description } & \multicolumn{2}{|c|}{$\begin{array}{c}\text { Second regeneration } \\
\text { ef f luent }\end{array}$} & \multicolumn{2}{|c|}{ Post Cs-IX evaporator LLW feed } & \multirow{2}{*}{$\begin{array}{c}\begin{array}{c}\text { Post Cs-IX } \\
\text { evaporator over- } \\
\text { heads }\end{array} \\
\begin{array}{c}\text { Mass } \\
\text { (kgs) }\end{array}\end{array}$} \\
\hline Component & MW & $\begin{array}{l}\text { Mass } \\
\text { (kgs) }\end{array}$ & $\underline{M}$ & $\begin{array}{l}\text { Mass } \\
(\mathrm{kgs})\end{array}$ & $\underline{M}$ & \\
\hline $\mathrm{Pb}^{44}$ & 207 & -- & -- & $3.32 E+01$ & 3.37 E-05 & -- \\
\hline $\begin{array}{l}\text { Rare } \\
\text { earths }+3\end{array}$ & -- & -- & - & $5.91 E+01$ & - & -- \\
\hline $\mathrm{Rh}^{* 3}$ & 103 & -- & -- & $1.04 E+01$ & $2.12 E-05$ & -- \\
\hline $\mathrm{Ru}^{+3}$ & 101 & $\cdots$ & -- & $2.36 E+01$ & $4.91 E-05$ & $-\cdot$ \\
\hline $\mathrm{Si}^{+4}$ & 28 & $\cdots$ & -- & $2.08 E+03$ & $1.56 E-02$ & -- \\
\hline $\mathrm{Th}^{+4}$ & 232 & - & $\cdots$ & $1.92 E+01$ & $1.74 E-05$ & - \\
\hline $\mathrm{Ti}^{* 4}$ & 48 & $\cdots$ & $\cdots$ & $4.45 E+00$ & $1.95 E-05^{\circ}$ & -- \\
\hline $\mathrm{UO}_{2}^{+2}$ & 270 & $\cdots$ & -- & $5.12 E+03$ & $3.99 E-03$ & -- \\
\hline $2 n^{+2}$ & 65 & $-\cdot$ & -- & $4.20 \mathrm{E}+01$ & $1.36 E-04$ & - \\
\hline $\mathrm{AlO}_{2}^{-}$ & 59 & $-\cdot$ & - & $6.52 E+04$ & 2.33 E-01 & $\cdots$ \\
\hline $\mathrm{Cl}^{-}$ & 35 & -- & $-\cdot$ & $7.19 E+02$ & $4.32 \mathrm{E}-03$ & -- \\
\hline $\mathrm{CO}_{3-2}$ & 60 & -- & -- & $3.34 E+04$ & 1.17 E-01 & -- \\
\hline$F^{-}$ & 19 & $\cdots$ & -- & $7.24 E+03$ & 8.02 E-02 & -- \\
\hline $\mathrm{NO}_{2}^{-}$ & 46 & -- & -- & $1.26 E+05$ & 5.78 E- 01 & -- \\
\hline $\mathrm{NO}_{3}{ }^{-}$ & 62 & $\cdots$ & -- & $3.65 E+05$ & $1.24 E+00$ & $\cdots$ \\
\hline $\mathrm{OH}^{-}$ & 17 & $2.65 E+03$ & $2.00 E+00$ & $1.75 E+05$ & $2.16 E+00$ & -- \\
\hline $\mathrm{PO}_{4}^{-3}$ & 95 & $\cdots$ & $\cdots$ & $4.40 E+04$ & $9.76 E-02$ & $\cdots$ \\
\hline $\mathrm{SO}_{4}^{-2}$ & 96 & $\cdots$ & - & $1.01 E+05$ & $2.21 \mathrm{E}-01$ & $\cdots$ \\
\hline TOC & - & $\cdots$ & -- & $7.99 E+03$ & $\cdots$ & -- \\
\hline $\mathrm{MnO}_{2}$ & 87 & $\cdots$ & $-\cdot$ & $8.41 E+00$ & 2.04 E-05 & $\cdots$ \\
\hline $\mathrm{ZrO}_{2}: 2 \mathrm{H}_{2} \mathrm{O}$ & 159 & $\cdots$ & $\cdots$ & $6.20 E+01$ & $8.21 E-05$ & $\therefore$ \\
\hline $\mathrm{H}_{2} \mathrm{O}$ & 18 & $7.57 \mathrm{E}+04$ & - & $4.21 E+06$ & -- & $2.47 E+06$ \\
\hline Total & -- & $8.20 E+04$ & -- & $5.69 E+06$ & -- & $2.47 E+06$ \\
\hline
\end{tabular}

(a) Intermittent process stream.

${ }^{(b)}$ Includes all isotopes of cesium. 
Table 12-7. Cesium Ion Exchange, Neutralized Current Acid Waste, Resorcinol-Formaldehyde Resin, Major Process Stream Data. (2 sheets)

\begin{tabular}{|c|c|c|c|c|c|}
\hline \multicolumn{2}{|c|}{ Stream number } & \multicolumn{2}{|c|}{470} & \multicolumn{2}{|c|}{560} \\
\hline \multicolumn{2}{|c|}{ Description } & \multicolumn{2}{|c|}{ LLW glass feed } & \multicolumn{2}{|c|}{ Eluate Concentrator Feed } \\
\hline \multicolumn{2}{|c|}{ Temperature $\left({ }^{\circ} \mathrm{C}\right)$} & \multicolumn{2}{|c|}{$\cdots$} & \multicolumn{2}{|c|}{-} \\
\hline \multicolumn{2}{|c|}{ Total volume $(L)$} & \multicolumn{2}{|c|}{$2.27 E+06$} & \multicolumn{2}{|c|}{$5.46 E+05$} \\
\hline \multicolumn{2}{|c|}{$\begin{array}{l}\text { Instantaneous design flow } \\
\text { rate }(L / m i n)\end{array}$} & \multicolumn{2}{|c|}{50} & \multicolumn{2}{|c|}{12} \\
\hline \multicolumn{2}{|c|}{$\begin{array}{l}\text { Total suspended solids } \\
\text { (ppm) }\end{array}$} & \multicolumn{2}{|c|}{--} & \multicolumn{2}{|c|}{--} \\
\hline \multicolumn{2}{|c|}{ Specific gravity } & \multicolumn{2}{|c|}{1.41} & \multicolumn{2}{|c|}{1.02} \\
\hline Component & MW & $\begin{array}{l}\text { Mass } \\
\text { (kgs) }\end{array}$ & $\begin{array}{l}\text { Mass } \\
\text { (kgs) }\end{array}$ & $\begin{array}{l}\text { Mass } \\
(\mathrm{kgs})\end{array}$ & $\underline{M}$ \\
\hline $\mathrm{Ag}^{+}$ & 108 & $2.84 E+01$ & $1.16 \mathrm{E}-04$ & -- & -- \\
\hline $\mathrm{Al}^{+3}$ & 27 & 0 & 0 & -- & -- \\
\hline $\mathrm{As}^{+5}$ & 75 & $1.77 \mathrm{E}+02$ & $1.04 E-03$ & -- & $\cdots$ \\
\hline$B^{-3}$ & 11 & $7.89 E+01$ & $3.15 \mathrm{E}-03$ & - & $\cdots$ \\
\hline $\mathrm{Ba}^{+2}$ & 137 & $9.53 E+00$ & 3.06 E-05 & $\cdots$ & $-\cdot$ \\
\hline $\mathrm{Be}^{-2}$ & 9 & 6.95 E-01 & $3.40 E-05$ & -- & $\cdots$ \\
\hline $\mathrm{Ca}^{2}$ & 40 & $4.08 E+01$ & $4.49 \mathrm{E}-04$ & $-\cdot$ & $\cdots$ \\
\hline $\mathrm{Cd}^{2}$ & 112 & $1.75 E+01$ & $6.86 E-05$ & -- & -- \\
\hline $\mathrm{Co}^{* 3}$ & 59 & $3.18 E+01$ & 2.37 E-04 & $-\cdot$ & $\cdots$ \\
\hline $\mathrm{Cs}^{*(1)}$ & 134 & $4.19 \mathrm{E}-02$ & $1.38 \mathrm{E}=07$ & $3.40 E+02$ & $2.70 E-03$ \\
\hline $\mathrm{Cr}^{-3}$ & 52 & $4.82 E+03$ & $4.08 \mathrm{E}-02$ & -- & -- \\
\hline $\mathrm{Cu}^{+2}$ & 64 & $1.01 E+01$ & $6.93 \mathrm{E}-05$ & -- & -- \\
\hline $\mathrm{Fe}^{.3}$ & 56 & $8.27 E+01$ & $6.50 \mathrm{E}-04$ & -- & -- \\
\hline$H^{*}$ & 1 & 0 & 0 & $2.19 E+02$ & $4.21 E-01$ \\
\hline$K^{*}$ & 39 & $1.85 E+04$ & 2.10 E-01 & $1.09 E+02$ & $5.28 E-03$ \\
\hline $\mathrm{Mg}^{\circ 2}$ & 24 & $1.09 E+01$ & $1.99 \mathrm{E}-04$ & $-\cdot$ & $\cdots$ \\
\hline $\mathrm{Mo}^{.6}$ & 96 & $4.45 E+02$ & 2.04 E-03 & $\cdots$ & $\cdots$ \\
\hline $\mathrm{Na}^{+}$ & 23 & $5.23 E+05$ & $1.00 \mathrm{E}+01$ & $8.81 E+02$ & $4.07 E-02$ \\
\hline $\mathrm{Ni}^{* 3}$ & 59 & $1.35 E+01$ & $1.00 \mathrm{E}-04$ & -- & -- \\
\hline
\end{tabular}


Table 12-7:- Cesium Ion Exchange, Neutralized Current Acid Waste, Resorcinol-Formaldehyde Resin, Major Process Stream Data. (2 sheets)

\begin{tabular}{|c|c|c|c|c|c|}
\hline \multicolumn{2}{|c|}{ Strearn number } & \multicolumn{2}{|c|}{470} & \multicolumn{2}{|c|}{570} \\
\hline \multicolumn{2}{|c|}{ Description } & \multicolumn{2}{|c|}{ LLW glass feed } & \multicolumn{2}{|c|}{ Eluate concentrator feed } \\
\hline Component & MW & $\begin{array}{l}\text { Mass } \\
(\mathrm{kgs})\end{array}$ & $\begin{array}{l}\text { Mass } \\
\text { (kgs) }\end{array}$ & $\begin{array}{l}\text { Mass } \\
\text { (kgs) }\end{array}$ & $\underline{M}$ \\
\hline $\mathrm{Pb}^{+4}$ & 207 & $3.32 E+01$ & $7.05 \mathrm{E}-05$ & $-\cdot$ & -- \\
\hline Rare Earths ${ }^{+3}$ & -- & $5.91 \mathrm{E}+01$ & -- & -- & -- \\
\hline $\mathrm{Rh}^{+3}$ & 103 & $1.04 E+01$ & $4.43 E-05$ & -- & - \\
\hline $\mathrm{Ru}^{+3}$ & 101 & $2.36 \mathrm{E}+01$ & $1.03 \mathrm{E}-04$ & $\cdots$ & -- \\
\hline $\mathrm{Si}^{+4}$ & 28 & $2.08 \mathrm{E}+03$ & $3.26 \mathrm{E}-02$ & $\cdots$ & - \\
\hline $\mathrm{Th}^{+4}$ & 232 & $1.92 \mathrm{E}+01$ & $3.64 E-05$ & $-\cdot$ & -- \\
\hline $\mathrm{Ti}^{+4}$ & 48 & $4.45 E+00$ & 4.08 E-05 & -- & -- \\
\hline $\mathrm{UO}_{2}^{+2}$ & 270 & $5.12 \mathrm{E}+03$ & 8.34 E-03 & -- & -- \\
\hline $2 n^{* 2}$ & 65 & $4.20 \mathrm{E}+01$ & 2.84 E-04 & $-\cdot$ & -- \\
\hline $\mathrm{AlO}_{2}^{-}$ & 59 & $6.52 E+04$ & 4.86 E-01 & - & -- \\
\hline $\mathrm{Cl}^{-}$ & 35 & $7.19 E+02$ & $9.03 \mathrm{E}-03$ & $-\cdot$ & -- \\
\hline $\mathrm{CO}_{3}^{-2}$ & 60 & $3.34 E+04$ & $2.45 \mathrm{E}-01$ & -- & - \\
\hline$F^{-}$ & 19 & $7.24 E+03$ & $1.67 \mathrm{E}-01$ & -- & -- \\
\hline $\mathrm{NO}_{2}^{-}$ & 46. & $1.26 E+05$ & $1.21 E+00$ & -- & 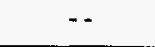 \\
\hline $\mathrm{NO}_{3}^{-}$ & 62 & $3.65 E+05$ & $2.59 E+00$ & $1.61 E+04$ & 2.77 E-01 \\
\hline $\mathrm{OH}^{-}$ & 17 & $1.75 E+05$ & $4.52 E+00$ & -- & -- \\
\hline $\mathrm{PO}_{4}^{-3}$ & 95 & $4.40 E+04$ & 2.04 E-01 & -- & -- \\
\hline $\mathrm{SO}_{4}^{-2}$ & 96 & $1.10 E+05$ & 4.62 E-01 & $\because$ & $\cdots$ \\
\hline TOC & $-\cdot$ & $7.99 E+03$ & $\cdots$ & -- & -- \\
\hline $\mathrm{MnO}_{2}$ & 87 & $8.41 E+00$ & 4.25 E-05 & $\cdots$ & $\cdots$ \\
\hline $\mathrm{ZrO}_{2}=2 \mathrm{H}_{2} \mathrm{O}$ & 159 & $6.20 E+01$ & 1.71 E-04 & -- & $\cdots$ \\
\hline $\mathrm{H}_{2} \mathrm{O}$ & 18 & $1.73 E+06$ & -- & $5.37 E+05$ & -- \\
\hline Total & -- & $3.21 E+06$ & $\cdots$ & $5.54 E+05$ & -- \\
\hline
\end{tabular}

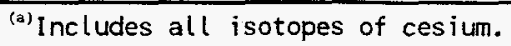


Table 12-8. Cesium Ion Exchange, Neutralized Current Acid Waste, Resorcinol-Formaldehyde Resin, Major Process Stream Data.. (2 sheets)

\begin{tabular}{|c|c|c|c|c|c|c|}
\hline \multicolumn{2}{|c|}{ Stream number } & \multicolumn{2}{|c|}{380} & 565 & 280 & 570 \\
\hline \multicolumn{2}{|c|}{ Description } & \multicolumn{2}{|c|}{$\begin{array}{c}\text { Eluate concentrator } \\
\text { overheads }\end{array}$} & $\begin{array}{c}\text { Eluate } \\
\text { concentrator } \\
\text { bottoms }\end{array}$ & $\begin{array}{c}\text { Eluate } \\
\text { neutralization } \\
\text { solution }\end{array}$ & Neutralized eluate \\
\hline \multicolumn{2}{|c|}{$\begin{array}{l}\text { Temperature } \\
\left({ }^{\circ} \mathrm{C}\right)\end{array}$} & \multicolumn{2}{|c|}{25} & 25 & 25 & 25 \\
\hline \multicolumn{2}{|c|}{ Total volume $(L)$} & \multicolumn{2}{|c|}{$5.08 E+05$} & $1.23 E+04$ & $6.08 E+03$ & $1.61 E+04$ \\
\hline \multicolumn{2}{|c|}{$\begin{array}{l}\text { instantaneous } \\
\text { design flow rate } \\
\text { (L/min) }\end{array}$} & \multicolumn{2}{|c|}{11} & 1.0 & 0.2 & 1.0 \\
\hline \multicolumn{2}{|l|}{$\mathrm{pH}$} & \multicolumn{2}{|c|}{$<1.0$} & $<1.0$ & $>13$ & $>13$ \\
\hline \multicolumn{2}{|c|}{ Specific gravity } & \multicolumn{2}{|c|}{1.02} & 1.3 & 1.4 & 1.3 \\
\hline Component & MW & \multicolumn{2}{|l|}{$\begin{array}{l}\text { mass } \\
\text { (kgs) }\end{array}$} & $\begin{array}{l}\text { mass } \\
\text { (kgs) }\end{array}$ & $\begin{array}{l}\text { mass } \\
\text { (kgs) }\end{array}$ & $\begin{array}{l}\text { mass } \\
\text { (kgs) }\end{array}$ \\
\hline $\mathrm{Ag}^{\circ}$ & 108 & -- & -- & -- & -- & -- \\
\hline $\mathrm{Al}^{+3}$ & 27 & -- & -- & -- & -- & -- \\
\hline As $^{.5}$ & 75 & - - & - - & -- & -- & -- \\
\hline $\mathrm{B}^{+3}$ & 11 & $\cdots$ & -- & -- & -- & $\therefore$ \\
\hline $8 a^{+2}$ & 137 & $\cdots$ & -- & -- & -- & -- \\
\hline $\mathrm{Be}^{* 2}$ & 9 & $\cdots$ & -- & $=$ & $-\cdots$ & -- \\
\hline $\mathrm{Ca}^{+2}$ & 40 & $\cdots$ & - & -- & -- & $\cdots$ \\
\hline $\mathrm{Cd}^{+2}$ & 112 & -- & -- & $=-$ & -- & - \\
\hline $\mathrm{Co}^{+3}$ & 59 & -- & $\cdots$ & -- & -- & -- \\
\hline $\mathrm{Cs}^{+(a)}$ & 134 & trace & $\cdots$ & 340 & $\cdots$ & 340 \\
\hline $\mathrm{Cr}^{+3}$ & 52 & -- & -- & -- & $\cdots$ & -- \\
\hline $\mathrm{Cu}^{+2}$ & 64 & -- & -- & -- & -- & $\cdots$ \\
\hline $\mathrm{Fe}^{.3}$ & 56 & -- & -- & $-\infty$ & -- & -- \\
\hline $\mathrm{H}^{+}$ & 1 & $1.53 E+02$ & $2.09 E-01$ & $6.6 E+01$ & -- & -- \\
\hline$K^{*}$ & 39 & -- & $\cdots$ & $1.07 E+02$ & -- & $1.07 E+02$ \\
\hline $\mathrm{Mg}^{+2}$ & 24 & -- & $\because$ & $\cdots$ & -- & - \\
\hline $\mathrm{Mo}^{+6}$ & 96 & -- & -- & -- & -- & $=-$ \\
\hline $\mathrm{Na}^{+}$ & 23 & -- & $\cdots$ & $8.81 E+03$ & $2.05 E+03$ & $2.93 E+03$ \\
\hline $\mathrm{Ni+3}$ & 59 & -- & $\cdots$ & $\therefore$ & -- & -- \\
\hline
\end{tabular}


Table 12-8. Cesium Ion Exchange, Neutralized Current Acid Waste, Resorcinol-Formaldehyde Resin, Major Process Stream Data. (2 sheets)

\begin{tabular}{|c|c|c|c|c|c|c|}
\hline \multicolumn{2}{|c|}{ Stream number } & \multicolumn{2}{|c|}{380} & 565 & 280 & 570 \\
\hline \multicolumn{2}{|c|}{ Description } & \multicolumn{2}{|c|}{$\begin{array}{c}\text { Eluate concentrator } \\
\text { overheads }\end{array}$} & $\begin{array}{l}\text { Eluate } \\
\text { concentrator } \\
\text { bottoms }\end{array}$ & $\begin{array}{c}\text { Eluate } \\
\text { neutralization } \\
\text { solution }\end{array}$ & Neutralized eluate \\
\hline Component & MW & $\begin{array}{l}\text { mass } \\
\text { (kgs) }\end{array}$ & $\underline{M}$ & $\begin{array}{l}\text { mass } \\
(\mathrm{kgs})\end{array}$ & $\begin{array}{l}\text { mass } \\
\text { (kgs) }\end{array}$ & $\begin{array}{l}\operatorname{mass} \\
(\mathrm{kgs})\end{array}$ \\
\hline $\mathrm{Pb}^{24}$ & 207 & -- & $-\cdot$ & -- & $\cdots$ & -- \\
\hline $\begin{array}{l}\text { Rare } \\
\text { Earths } 3\end{array}$ & -- & $-\cdot$ & -- & -- & $\cdots$ & -- \\
\hline $\mathrm{Rh}^{+3}$ & 103 & $\cdots$ & -- & -- & -- & -- \\
\hline $\mathrm{Ru}^{\cdot 3}$ & 101 & -- & $\cdots$ & -- & - & -- \\
\hline $\mathrm{Si}^{\cdot 4}$ & 28 & -- & -- & $\cdots$ & - & -- \\
\hline$T h^{+4}$ & 232 & - & -- & -- & - & -- \\
\hline $\mathrm{Ti}^{* 4}$ & 48 & - & -- & -- & $\cdots$ & -- \\
\hline $\mathrm{UO}_{2}^{\cdot 2}$ & 270 & -- & $\cdots$ & -- & - & -- \\
\hline $\mathrm{Zn}^{-2}$ & 65 & $\cdots$ & $\cdots$ & -- & -- & -- \\
\hline $\mathrm{AlO}_{2}^{-}$ & 59 & -- & $-\cdot$ & -- & -- & -- \\
\hline $\mathrm{Cl}^{-}$ & 35 & -- & - & $\cdots$ & -. & -- \\
\hline $\mathrm{CO}_{3}^{-2}$ & 60 & $\cdots$ & -- & $\cdots$ & $-\cdot$ & - \\
\hline$F^{-}$ & 19 & -. & -- & -- & -- & $\cdots$ \\
\hline $\mathrm{NO}_{2}^{-}$ & 46 & -- & -- & $\cdots$ & $8.00 E+02$ & $8.00 E+03$ \\
\hline $\mathrm{NO}_{3}^{-}$ & 62 & $9.51 E+03$ & $2.09 \mathrm{E}-01$ & $6.61 E+03$ & $\cdots$ & $6.61 E+03$ \\
\hline $\mathrm{OH}^{-}$ & 17 & - & -- & $\cdots$ & $1.22 E+03$ & $1.03 E+03$ \\
\hline $\mathrm{PO}_{4}^{-3}$ & 95 & -- & $\cdots$ & $\cdots$ & -. & -- \\
\hline $\mathrm{SO}_{4}^{-2}$ & 96 & -- & -- & -- & - & -- \\
\hline TOC & -. & - & -. & -- & -- & -- \\
\hline $\mathrm{MnO}_{2}$ & 87 & -- & - & $\cdots$ & $-\cdot$ & -- \\
\hline $\mathrm{ZrO}_{2}: 2 \mathrm{H}_{2} \mathrm{O}$ & 159 & -- & -- & - & -- & -- \\
\hline $\mathrm{H}_{2} \mathrm{O}$ & 18 & $5.03 E+05$ & - & $7.66 E+03$ & $4.67 E+03$ & $1.39 E+04$ \\
\hline Total & - & $5.13 E+05$ & - & $1.56 E+03$ & $8.74 E+03$ & $2.51 E+04$ \\
\hline
\end{tabular}

(a) Includes all isotopes of cesium. 


\section{WHC-SD-WM-TI-638 REV 0}

\subsection{DOUBLE-SHELL SLURRY FEED MATERIAL BALANCE}

The estimated cesium inventory is $1.18 \times 10^{7} \mathrm{Ci}{ }^{137} \mathrm{Cs}$ in DSSF. The cesium inventories were obtained from $p$. D-51 from document WHC-EP-0616. The decay daughters are not included. D-51 and 4-13 of WHC-EP-0616. The radionuclides have been decayed to the end of 1995 . The isotopic ratio for ${ }^{137} \mathrm{Cs}$ is about

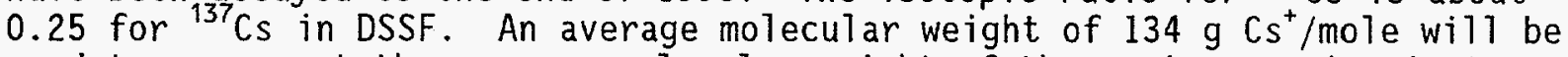
used to represent the average molecular weight of the various cesium isotopes in the tank waste.

Tables 12-9 through 12-16 summarize the material balance for use of $R-F$ resin as an ion exchange material to remove cesium from DSSF waste. 
WHC-SD-WM-TI-638 REV 0

This page intentionally left blank. 
Table 12-9. "Cesium Ion Exchange, Double-Shell Slurry

Feed, Resorcinol-Formaldehyde Resin, Major

Process Stream Data. (2 sheets)

\begin{tabular}{|c|c|c|c|c|c|c|c|}
\hline \multicolumn{2}{|c|}{ Stream number } & \multicolumn{2}{|c|}{ - - } & 120 & 520 & \multicolumn{2}{|c|}{420} \\
\hline \multicolumn{2}{|c|}{ Description } & \multicolumn{2}{|c|}{ DSSF in tank } & $\begin{array}{c}\text { Solutions for } \\
\text { retrieval and } \\
\text { sludge } \\
\text { washing }\end{array}$ & $\begin{array}{l}\text { Sludge washed } \\
\text { solids } \\
\text { to HLW glass }\end{array}$ & \multicolumn{2}{|c|}{$\begin{array}{l}\text { Sludge washed } \\
\text { DSSF supernate }\end{array}$} \\
\hline \multicolumn{2}{|c|}{$\begin{array}{l}\text { Temperature } \\
\left({ }^{\circ} \mathrm{C}\right)\end{array}$} & \multicolumn{2}{|c|}{--} & 25 & $\cdots$ & \multicolumn{2}{|c|}{40} \\
\hline \multicolumn{2}{|c|}{ Total volume (L) } & \multicolumn{2}{|c|}{$4.93 E+07$} & $2.09 E+07$ & 0 & \multicolumn{2}{|c|}{$7.02 E+07$} \\
\hline \multicolumn{2}{|c|}{$\begin{array}{l}\text { Instantaneous } \\
\text { design flow rate } \\
(\mathrm{L} / \mathrm{min})\end{array}$} & \multicolumn{2}{|c|}{ (a) } & -. & $0^{(a)}$ & \multicolumn{2}{|c|}{--} \\
\hline \multicolumn{2}{|c|}{$\begin{array}{l}\text { Total suspended } \\
\text { solids }\end{array}$} & \multicolumn{2}{|c|}{$w t \%$} & 0 & $\cdots$ & \multicolumn{2}{|c|}{ ppm } \\
\hline \multicolumn{2}{|c|}{ Specific gravity } & \multicolumn{2}{|c|}{1.61} & 1.00 & $\cdots$ & \multicolumn{2}{|c|}{1.43} \\
\hline Component & MW & $\begin{array}{c}\text { Mass } \\
\text { insoluble } \\
\text { (kgs) }\end{array}$ & $\begin{array}{l}\text { Mass } \\
\text { soluble } \\
\text { (kgs) }\end{array}$ & $\begin{array}{l}\text { Mass } \\
\text { (kgs) }\end{array}$ & $\begin{array}{l}\text { Mass } \\
\text { (kgs) }\end{array}$ & $\begin{array}{l}\text { Mass } \\
(\mathrm{kgs})\end{array}$ & $\underline{M}$ \\
\hline$B^{* 3}$ & 11 & 0 & $1.29 E+01$ & -- & $-\cdot$ & $1.29 E+01$ & $1.67 E-05$ \\
\hline $\mathrm{Ba}^{* 2}$ & 137 & 0 & $2.98 E+02$ & $\rightarrow$ & -- & $2.98 E+02$ & 3.10 E-05 \\
\hline $\mathrm{Ca}^{* 2}$ & 40 & 0 & $3.34 E+03$ & $\cdots$ & -- & $3.34 E+03$ & $1.19 E-03$ \\
\hline $\mathrm{Cd}^{+2}$ & 112 & 0 & $2.79 E+02$ & $\cdots$ & $\cdots$ & $2.79 E+02$ & 3.55 E-05 \\
\hline $\mathrm{Co}^{* 3}$ & 59 & 0 & 1.09 E-03 & -- & -- & 1.09 E-03 & $2.63 E-01$ \\
\hline $\mathrm{Cs}^{*(\mathrm{~b})}$ & 134 & 0 & $5.45 E+02$ & -- & $\cdots$ & $5.45 E+02$ & 5.79 E-05 \\
\hline $\mathrm{Cr}^{.3}$ & 52 & 0 & $2.30 E+04$ & -- & $\cdots$ & $2.30 E+04$ & $6.30 E-03$ \\
\hline $\mathrm{Cu}^{+2}$ & 64 & 0 & $2.09 E+02$ & $\cdots$ & $\cdots$ & $2.09 E+02$ & $4.65 E-05$ \\
\hline $\mathrm{Fe}^{* 3}$ & 56 & 0 & $1.13 E+03$ & -- & -- & $1.13 E+03$ & $2.87 E-04$ \\
\hline $\mathrm{H}^{+}$ & 1 & 0 & 0 & - & $\cdots$ & 0 & 0 \\
\hline $\mathrm{Hg}^{+2}$ & 201 & 0 & $2.80 E+02$ & -- & $\cdots$ & $2.80 E+02$ & 1.98 E-05 \\
\hline $\mathrm{K}^{*}$ & 39 & 0 & $1.31 E+06$ & $-\cdot$ & $\cdots$ & $1.31 E+06$ & 4.78 E- 01 \\
\hline $\mathrm{Mg}^{* 2}$ & 24 & 0 & $5.23 E+02$ & $\cdots$ & $\cdots$ & $5.23 E+02$ & $3.10 E-04$ \\
\hline $\mathrm{Mo}^{* 6}$ & 96 & 0 & $2.77 E+03$ & $\cdots$ & -- & $2.77 E+03$ & $4.11 E-04$ \\
\hline $\mathrm{Na}^{+}$ & 23 & 0 & $1.13 E+07$ & 0 & $\cdots$ & $1.13 E+07$ & $7.00 E+00$ \\
\hline $\mathrm{Ni}^{+3}$ & 59 & 0 & $5.61 E+02$ & -- & - & $5.61 E+02$ & $1.35 E-04$ \\
\hline
\end{tabular}


Table 12-9. Cesium Ion Exchange, Double-Shell Slurry

Feed, Resorcinol-Formaldehyde Resin, Major Process Stream Data. (2 sheets)

\begin{tabular}{|c|c|c|c|c|c|c|c|}
\hline \multicolumn{2}{|c|}{ Stream number } & \multicolumn{2}{|c|}{$\cdots$} & \multirow{2}{*}{$\begin{array}{c}120 \\
\text { Solutions for } \\
\text { retrieval and } \\
\text { sludge } \\
\text { washing }\end{array}$} & \multirow{2}{*}{$\begin{array}{l}520 \\
\begin{array}{c}\text { Sludge washed } \\
\text { sol ids } \\
\text { to HLW glass }\end{array}\end{array}$} & \multicolumn{2}{|c|}{420} \\
\hline \multicolumn{2}{|c|}{ Description } & \multicolumn{2}{|c|}{ DSSF in tank } & & & \multicolumn{2}{|c|}{$\begin{array}{l}\text { Sludge washed } \\
\text { DSSF supernate }\end{array}$} \\
\hline Component & MW & $\begin{array}{l}\text { Mass } \\
\text { insoluble } \\
\quad(\mathrm{kgs})\end{array}$ & $\begin{array}{l}\text { Mass } \\
\text { soluble } \\
\text { (kgs) }\end{array}$ & $\begin{array}{l}\text { Mass } \\
\text { (kgs) }\end{array}$ & $\begin{array}{l}\text { Mass } \\
\text { (kgs) }\end{array}$ & $\begin{array}{l}\text { Mass } \\
(\mathrm{kgs})\end{array}$ & $\underline{M}$ \\
\hline $\mathrm{Pb}^{+4}$ & 207 & 0 & $2.65 E+03$ & -- & -- & $2.65 E+03$ & $1.82 E-04$ \\
\hline $\begin{array}{l}\text { Rare } \\
\text { Earths } \cdot 3\end{array}$ & -- & 0 & $5.16 E-01$ & $\cdots$ & -- & $5.16 \varepsilon-01$ & - \\
\hline $\mathrm{Rh}^{\cdot 3}$ & 103 & 0 & $1.28 E+00$ & $\cdots$ & $-\cdot$ & $1.28 E+00$ & $1.77 \mathrm{E}-07$ \\
\hline $\mathrm{Ru}^{* 3}$ & 101 & 0 & $6.17 \mathrm{E}-01$ & -- & -- & $6.17 E-01$ & $8.70 E-08$ \\
\hline $\mathrm{Si}^{* 4}$ & 28 & 0 & $8.12 E+03$ & -- & $\cdots$ & $8.12 E+03$ & $4.13 E-03$ \\
\hline $\mathrm{Ti}^{* 4}$ & 48 & 0 & $1.46 E+00$ & -- & - & $1.46 E+00$ & 4.33 E- 07 \\
\hline $\mathrm{UO}_{2}{ }^{-2}$ & 270 & 0 & $7.88 E+03$ & -- & $-\cdot$ & $7.88 E+03$ & 4.16 E-04 \\
\hline$Z^{-2}$ & 65 & 0 & $8.38 \mathrm{E}+02$ & -- & $\cdots$ & $8.38 E+02$ & 1.84 E-04 \\
\hline $\mathrm{AlO}_{2}^{-}$ & 59 & 0 & $3.38 E+06$ & -- & $\cdots$ & $3.38 E+06$ & $8.16 E-01$ \\
\hline $\mathrm{Cl}^{-}$ & 35 & 0 & $3.29 E+05$ & $\cdots$ & -- & $3.29 E+05$ & $1.34 E-01$ \\
\hline $\mathrm{CO}_{3}^{-2}$ & 60 & 0 & $2.85 E+05$ & -- & -- & $2.85 E+05$ & $6.77 E-02$ \\
\hline$F^{-}$ & 19 & 0 & $9.47 E+04$ & -- & $\cdots$ & $9.47 \mathrm{E}+04$ & 7.10 E-02 \\
\hline $\mathrm{Fe}(\mathrm{CN})_{6}^{-3}$ & 212 & 0 & $1.36 E+03$ & $-\infty$ & -- & $1.36 E+03$ & 9.14 E-05 \\
\hline $\mathrm{NO}_{2}^{-}$ & 46 & 0 & $4.77 E+06$ & 0 & -- & $4.77 E+06$ & $1.48 E+00$ \\
\hline $\mathrm{NO}_{3}^{-}$ & 62 & 0 & $9.29 E+06$ & -- & -- & $9.26 E+06$ & $2.13 E+00$ \\
\hline $\mathrm{OH}^{-}$ & 17 & 0 & $4.22 E+06$ & 0 & -- & $4.22 E+06$ & $3.54 E+00$ \\
\hline $\mathrm{PO}_{4}^{-3}$ & 95 & 0 & $3.55 E+04$ & - & -- & $3.55 E+04$ & $5.32 E-03$ \\
\hline $\mathrm{SO}_{4}^{-2}$ & 96 & 0 & $1.27 E+05$ & -- & - & $1.27 \mathrm{E}+05$ & $1.88 E-02$ \\
\hline TOC & -- & 0 & $1.52 E+05$ & -- & $-\cdot$ & $1.52 E+05$ & -- \\
\hline $\mathrm{MnO}_{2}$ & 87 & 0 & $7.95 E+02$ & -- & $-\cdot$ & $7.95 E+02$ & $1.30 E-04$ \\
\hline $\mathrm{H}_{2} \mathrm{O}$ & 18 & 0 & $4.41 E+07$ & $2.09 E+07$ & -- & $6.50 E+07$ & -- \\
\hline Total & -- & 0 & $7.94 E+07$ & $2.09 E+07$ & 0 & $1.00 E+08$ & -- \\
\hline
\end{tabular}

${ }^{(a)}$ Rate of waste volume only, does not including dilution water.

${ }^{(0)}$ Includes all isotopes of cesium. 
Table 12-10. Cesium Ion Exchange, Double-She11 Slurry

Feed, Resorcinol-Formaldehyde Resin, Major

Process Stream Data. (2 sheets)

\begin{tabular}{|c|c|c|c|c|c|c|c|}
\hline \multicolumn{2}{|c|}{ Stream number } & \multicolumn{2}{|c|}{427} & 130 & 530 & \multicolumn{2}{|c|}{430} \\
\hline \multicolumn{2}{|c|}{ Description } & \multicolumn{2}{|c|}{$\begin{array}{c}\text { Pre-Cs-Ix evaporator } \\
\text { bottoms }\end{array}$} & $\begin{array}{l}\text { Pre-Cs-IX } \\
\text { evaporator } \\
\text { overheads }\end{array}$ & $\begin{array}{l}\text { Filtered } \\
\text { solids }\end{array}$ & \multicolumn{2}{|c|}{ Cs-IX column LLW feed } \\
\hline \multicolumn{2}{|c|}{$\begin{array}{l}\text { Temperature } \\
\left({ }^{\circ} \mathrm{C}\right)\end{array}$} & \multicolumn{2}{|c|}{25} & -- & -- & \multicolumn{2}{|c|}{25} \\
\hline \multicolumn{2}{|c|}{ Total volume (L) } & \multicolumn{2}{|c|}{$7.02 \mathrm{E}+07$} & 0 & 0 & \multicolumn{2}{|c|}{$7.02 E+07$} \\
\hline \multicolumn{2}{|c|}{$\begin{array}{l}\text { Instantaneous } \\
\text { design flow rate } \\
\text { (L/min) }\end{array}$} & \multicolumn{2}{|c|}{-} & -- & $-\cdot$ & \multicolumn{2}{|c|}{-} \\
\hline \multicolumn{2}{|c|}{$\begin{array}{l}\text { Total suspended } \\
\text { sol ids }\end{array}$} & \multicolumn{2}{|c|}{$\mathrm{ppm}$} & -. & -. & \multicolumn{2}{|c|}{ - } \\
\hline \multicolumn{2}{|l|}{$\mathrm{pH}$} & \multicolumn{2}{|c|}{$-\cdot$} & $\cdots$ & $-\cdot$ & \multicolumn{2}{|c|}{$\cdots$} \\
\hline \multicolumn{2}{|c|}{ Specific gravity } & \multicolumn{2}{|c|}{$\cdots$} & -- & -- & \multicolumn{2}{|c|}{1.43} \\
\hline Component & MW & $\begin{array}{l}\text { Mass } \\
\text { (kgs) }\end{array}$ & $\underline{M}$ & $\begin{array}{l}\text { Mass } \\
\text { (kgs) }\end{array}$ & $\begin{array}{l}\text { Mass } \\
\text { (kgs) }\end{array}$ & $\begin{array}{l}\text { Mass } \\
\text { (kgs) }\end{array}$ & $\underline{M}$ \\
\hline $\mathrm{B}^{+3}$ & 11 & $1.29 E+01$ & 1.67 E-05 & $\cdots$ & -- & $1.29 E+01$ & 1.67 E-05 \\
\hline $\mathrm{Ba}^{+2}$ & 137 & $2.98 E+02$ & $3.10 E-05$ & $\because$ & $\cdots$ & $2.98 \mathrm{E}+02$ & 3.10 E-05 \\
\hline $\mathrm{Ca}^{+2}$ & 40 & $3.34 E+03$ & 1.19 E-03 & -- & - & $3.34 E+03$ & $1.19 E-03$ \\
\hline $\mathrm{Cd}^{-2}$ & 112 & $2.79 E+02$ & $3.55 \mathrm{E}-05$ & -- & -- & $2.79 E+02$ & 3.55 E-05 \\
\hline $\mathrm{CO}^{+3}$ & 59 & $1.09 \mathrm{E}-03$ & $2.63 E-10$ & -- & -- & $1.09 E-03$ & $2.63 E-10$ \\
\hline $\mathrm{Cs}^{+(a)}$ & 134 & $5.45 E+02$ & $5.79-05$ & -- & -- & $5.45 E+02$ & $5.79 E-05$ \\
\hline $\mathrm{Cr}^{+3}$ & 52 & $2.30 E+04$ & 6.30 E-03 & - & $-\cdot$ & $2.30 E+04$ & $6.30 E-03$ \\
\hline $\mathrm{Cu}^{+2}$ & 64 & $2.09 E+02$ & 4.65 E-05 & -- & -- & $2.09 E+02$ & $4.65 E-05$ \\
\hline $\mathrm{Fe}^{+3}$ & 56 & $1.13 E+03$ & 2.87 E-04 & $\cdots$ & -- & $1.13 E+03$ & 2.87 E-04 \\
\hline $\mathrm{H}^{*}$ & 1 & 0 & 0 & -- & - & 0 & 0 \\
\hline $\mathrm{Hg}^{22}$ & 201 & $2.80 E+02$ & 1.98 E-05 & -- & $\cdots$ & $2.80 E+02$ & -- \\
\hline $\mathrm{K}^{+}$ & 39 & $1.31 E+06$ & 4.78 E- 01 & $\cdots$ & $\cdots$ & $1.31 E+06$ & $4.78 E-01$ \\
\hline $\mathrm{Mg}^{-2}$ & 24 & $5.23 E+02$ & 3.10 E-04 & - & -- & $5.23 E+02$ & 3.10 E-04 \\
\hline $\mathrm{Mo}^{+6}$ & 96 & $2.77 \mathrm{E}+03$ & 4.11 E-04 & $\cdots$ & -- & $2.77 \cdot E+03$ & $4.11 E-04$ \\
\hline $\mathrm{Na}^{+}$ & 23 & $1.13 E+07$ & $7.00 E+00$ & $\cdots$ & -- & $1.13 \mathrm{E}+02$ & $7.00 E+00$ \\
\hline $\mathrm{Ni}^{+3}$ & 59 & $5.61 E+02$ & $1.35 E-04$ & -- & -- & $5.61 E+02$ & $1.35 E-04$ \\
\hline
\end{tabular}


Table 12-10. Cesium Ion Exchange, Double-Shell Slurry Feed, Resorcinol-Formaldehyde Resin, Major Process Stream Data. (2 sheets)

\begin{tabular}{|c|c|c|c|c|c|c|c|}
\hline \multicolumn{2}{|c|}{ Stream number } & \multicolumn{2}{|c|}{427} & \multirow{2}{*}{$\begin{array}{c}130 \\
\begin{array}{c}\text { Pre-Cs-IX } \\
\text { evaporator } \\
\text { overheads }\end{array}\end{array}$} & \multirow{2}{*}{$\begin{array}{c}530 \\
\begin{array}{c}\text { Filtered } \\
\text { solids }\end{array}\end{array}$} & \multicolumn{2}{|c|}{430} \\
\hline \multicolumn{2}{|c|}{ Description } & \multicolumn{2}{|c|}{$\begin{array}{c}\text { Pre-Cs-Ix evaporator } \\
\text { bottoms }\end{array}$} & & & $\mathrm{Cs}-\mathrm{IX} \mathrm{co}$ & LLW feed \\
\hline Component & MW & $\begin{array}{l}\text { Mass } \\
\text { (kgs) }\end{array}$ & M & $\begin{array}{l}\text { Mass } \\
\text { (kgs) }\end{array}$ & $\begin{array}{l}\text { Mass } \\
\text { (kgs) }\end{array}$ & $\begin{array}{l}\text { Mass } \\
(\mathrm{kgs})\end{array}$ & M \\
\hline $\mathrm{Pb}$ & 207 & $2.65 E+03$ & 1.82 E-04 & -- & $\cdots$ & $2.65 E+03$ & 1.82 E-04 \\
\hline $\begin{array}{l}\text { Rare } \\
\text { Earths }+3\end{array}$ & $\cdots$ & 5.16 E-01 & -- & -- & $-\cdot$ & $5.16 E-01$ & -- \\
\hline $\mathrm{Rh}^{-3}$ & 103 & $1.28 E+00$ & $1.77 E-07$ & -- & $\cdots$ & $1.28 E+00$ & 1.77 E-07 \\
\hline $\mathrm{Ru}^{+3}$ & 101 & 6.17 E-01 & $8.70 E-08$ & -- & -- & $6.17 E-01$ & $8.70 E-08$ \\
\hline $\mathrm{Si}^{+4}$ & 28 & $8.12 E+03$ & $4.13 \mathrm{E}-03$ & -- & $\cdots$ & $8.12 E+03$ & $4.13 E-03$ \\
\hline $\mathrm{Ti}^{+4}$ & 48 & $1.46 E+00$ & $4.33 E-07$ & -- & -- & $1.46 \mathrm{E}+00$ & $4.33 E-07$ \\
\hline $\mathrm{UO}_{2}^{\cdot 2}$ & 270 & $7.88 E+03$ & $4.16 \mathrm{E}-04$ & - & -- & $7.88 E+03$ & $4.16 \varepsilon-04$ \\
\hline $2 n^{+2}$ & 65 & $8.38 E+02$ & $1.84 E-04$ & $\cdots$ & -- & $8.38 E+02$ & 1.84 E-04 \\
\hline $\mathrm{AlO}_{2}^{-}$ & 59 & $3.38 E+06$ & $8.16 E-01$ & $\cdots$ & -- & $3.38 E+06$ & 8.16 E-01 \\
\hline $\mathrm{Cl}^{-}$ & 35 & $3.29 E+05$ & $1.34 E-01$ & $\cdots$ & -- & $3.29 E+05$ & 1.34 E-01 \\
\hline $\mathrm{CO}_{3}^{-2}$ & 60 & $2.85 E+05$ & 6.77 E-02 & $\cdots$ & - & $2.85 E+05$ & $6.77 \mathrm{E}-02$ \\
\hline$F^{-}$ & 19 & $9.47 E+04$ & $7.10 \mathrm{E}-02$ & $\cdots$ & -- & $9.47 E+04$ & $7.10 \mathrm{E}-02$ \\
\hline $\mathrm{Fe}(\mathrm{CN})_{6}^{-{ }^{-3}}$ & 212 & $1.36 E+03$ & $9.14 E-05$ & -- & -- & $1.36 E+03$ & $-\cdot$ \\
\hline $\mathrm{NO}_{2}^{-}$ & 46 & $4.77 E+06$ & $1.48 E+00$ & - & -- & $4.77 E+06$ & $1.48 E+00$ \\
\hline $\mathrm{NO}_{3}^{-}$ & 62 & $9.26 E+06$ & $2.13 E+00$ & $\cdots$ & -- & $9.26 E+06$ & $2.13 E+00$ \\
\hline $\mathrm{OH}^{-}$ & 17 & $4.22 E+06$ & $3.54 E+00$ & -- & $\cdots$ & $4.22 E+06$ & $3.54 E+00$ \\
\hline $\mathrm{PO}_{4}^{-3}$ & 95 & $3.55 E+04$ & $5.32 E-03$ & -- & -- & $3.55 E+04$ & $5.32 \mathrm{E}-03$ \\
\hline $\mathrm{SO}_{4}^{-2}$ & 96 & $1.27 E+05$ & $1.88 E-02$ & $\cdots$ & -- & $1.27 \mathrm{E}+05$ & $1.88 E-02$ \\
\hline TOC & $\cdots$ & $1.52 E+05$ & $-\cdot$ & -- & -- & $1.52 E+05$ & -- \\
\hline $\mathrm{MnO}_{2}$ & 87 & $7.95 E+02$ & 1.30 E-04 & $\cdots$ & -- & $7.95 \varepsilon+02$ & $1.30 \mathrm{E}-04$ \\
\hline $\mathrm{H}_{2} \mathrm{O}$ & 18 & $6.50 E+07$ & -- & $-\cdot$ & -- & $6.50 E+07$ & -- \\
\hline Total & $\cdots$ & $1.00 E+08$ & -- & 0 & 0 & $1.00 E+08$ & -- \\
\hline
\end{tabular}

(a) Includes all isotopes of cesium. 
Table 12-11. Cesium Ion Exchange, Double-Shell STurry

Feed, Resorcinol-Formaldehyde Resin, Major

Process Stream Data. (2 sheets)

\begin{tabular}{|c|c|c|c|c|c|c|c|}
\hline \multicolumn{2}{|c|}{ Stream number } & \multicolumn{2}{|c|}{440} & 140 & 545 & \multicolumn{2}{|c|}{320} \\
\hline \multicolumn{2}{|c|}{ Description } & \multicolumn{2}{|c|}{ LLW column effluent } & $\begin{array}{l}\text { Post load } \\
\text { water wash }\end{array}$ & $\begin{array}{c}\text { Post load } \\
\text { wash effluent }\end{array}$ & \multicolumn{2}{|c|}{ Elution solution } \\
\hline \multicolumn{2}{|c|}{$\begin{array}{l}\text { Temperature } \\
\left({ }^{\circ} \mathrm{C}\right)\end{array}$} & \multicolumn{2}{|c|}{25} & 25 & 25 & \multicolumn{2}{|c|}{25} \\
\hline \multicolumn{2}{|c|}{ Total volume $(L)$} & \multicolumn{2}{|c|}{$7.02 E+07$} & $8.16 E+05$ & $8.16 E+05$ & \multicolumn{2}{|c|}{$1.09 E+07$} \\
\hline \multicolumn{2}{|c|}{$\begin{array}{l}\text { Instantaneous } \\
\text { design flow rate } \\
(\mathrm{L} / \mathrm{min})\end{array}$} & \multicolumn{2}{|c|}{--} & 200 & 200 & \multicolumn{2}{|c|}{$100^{(a)}$} \\
\hline \multicolumn{2}{|l|}{$\mathrm{pH}$} & \multicolumn{2}{|c|}{$\cdots$} & 7.00 & 7.00 & \multicolumn{2}{|c|}{$\cdots$} \\
\hline \multicolumn{2}{|c|}{ Specific gravity } & \multicolumn{2}{|c|}{1.43} & 1.00 & 1.00 & \multicolumn{2}{|c|}{1.01} \\
\hline Component & MW & $\begin{array}{l}\text { Mass } \\
\text { (kgs) }\end{array}$ & $\underline{M}$ & $\begin{array}{l}\text { Mass } \\
\text { (kgs) }\end{array}$ & $\begin{array}{l}\text { Mass } \\
(\mathrm{kgs})\end{array}$ & $\begin{array}{l}\text { Mass } \\
\text { (kgs) }\end{array}$ & $\underline{M}$ \\
\hline$B^{* 3}$ & 11 & $1.29 E+01$ & $1.67 E-05$ & -- & -- & -- & -- \\
\hline$B a^{+2}$ & 137 & $2.98 E+02$ & $3.10 \mathrm{E}-05$ & -. & -- & -- & -- \\
\hline $\mathrm{Ca}^{+2}$ & 40 & $3.34 E+03$ & $1.19 E-03$ & $\cdots$ & -- & - & - \\
\hline $\mathrm{Cd}^{2}$ & 112 & $2.79 E+02$ & $3.55 E-05$ & $\cdots$ & - & $-\cdot$ & -- \\
\hline $\mathrm{CO}^{+3}$ & 59 & 1.09 E-03 & $2.63 E-10$ & - & -- & -- & - \\
\hline$C s^{+(b)}$ & 134 & $1.30 E+00$ & $1.38 E-07$ & -- & -- & -- & -- \\
\hline $\mathrm{Cr}^{.3}$ & 52 & $2.30 E+04$ & 6.30 E-03 & - & $\cdots$ & $\cdots$ & -- \\
\hline $\mathrm{Cu}^{+2}$ & 64 & $2.09 E+02$ & $4.65 E-05$ & -- & -- & -- & -- \\
\hline $\mathrm{Fe}^{.3}$ & 56 & $1.13 E+03$ & $2.87 E-04$ & -- & -- & -- & -- \\
\hline $\mathrm{H}^{*}$. & 1 & 0 & 0 & $\cdots$ & - & $5.44 E+03$ & $5.00 E-01$ \\
\hline $\mathrm{Hg}^{+2}$ & 201 & $\cdots$ & - & - & -- & - & $\cdots$ \\
\hline $\mathrm{K}^{*}$ & 39 & $1.31 E+06$ & 4.78 E-01 & -- & -- & -- & -- \\
\hline $\mathrm{Mg}^{+2}$ & .24 & $5.23 E+02$ & 3.10 E-04 & $\cdots$ & $-\cdot$ & $\cdots$ & -- \\
\hline $\mathrm{MO}^{+6}$ & 96 & $2.77 E+03$ & 4.11 E-04 & - & -- & -- & -- \\
\hline $\mathrm{Na}^{\prime}$ & 23 & $1.13 E+07$ & $7.00 E+00$ & -- & $\cdots$ & -- & -- \\
\hline $\mathrm{Ni}^{+3}$ & 59 & $5.16 E+02$ & 1.35 E-04 & $\cdots$ & - & $\cdots$ & - \\
\hline
\end{tabular}


Table 12-11. Cesium Ion Exchange, Double-Shell Slurry Feed, Resorcinol-Formaldehyde Resin, Major Process Stream Data. (2 sheets)

\begin{tabular}{|c|c|c|c|c|c|c|c|}
\hline \multicolumn{2}{|c|}{ stream number } & \multicolumn{2}{|c|}{440} & 140 & 545 & \multicolumn{2}{|c|}{320} \\
\hline \multicolumn{2}{|c|}{ Description } & \multicolumn{2}{|c|}{ LLW column effluent } & \multirow{2}{*}{$\begin{array}{c}\begin{array}{c}\text { Post load } \\
\text { water wash }\end{array} \\
\begin{array}{c}\text { Mass } \\
(\mathrm{kgs})\end{array}\end{array}$} & \multirow{2}{*}{$\begin{array}{c}\begin{array}{c}\text { Post load } \\
\text { wash effluent }\end{array} \\
\begin{array}{c}\text { Mass } \\
\text { (kgs) }\end{array}\end{array}$} & \multicolumn{2}{|c|}{ Elution solution } \\
\hline Component & MW & $\begin{array}{l}\text { Mass } \\
\text { (kgs) }\end{array}$ & $\underline{M}$ & & & $\begin{array}{l}\text { Mass } \\
\text { (kgs) }\end{array}$ & $\underline{\mathrm{M}}$ \\
\hline $\mathrm{Pb}^{+4}$ & 207 & $2.65 E+03$ & 1.82 E-04 & - & -- & -- & -- \\
\hline $\begin{array}{l}\text { Rare } \\
\text { Earths *3 }\end{array}$ & $\cdots$ & $5.16 E-01$ & $\cdots$ & -- & $\cdots$ & - & - \\
\hline $\mathrm{Rh}^{+3}$ & 103 & $1.28 E+00$ & 1.77 E-07 & -- & -- & - & -- \\
\hline$R u^{* 3}$ & 101 & $6.17 E-01$ & $8.70 E-08$ & -- & -- & -- & -- \\
\hline$S i^{+4}$ & 28 & $8.12 E+03$ & $4.13 E-03$ & -- & -- & -- & - \\
\hline $\mathrm{Ti}^{* 4}$ & 48 & $1.46 E+00$ & $4.33 \quad E-07$ & $=$ & $\cdots$ & -- & -- \\
\hline $\mathrm{UO}_{2}{ }^{22}$ & 270 & $7.88 E+03$ & $4.16 E-04$ & -- & -- & - & -- \\
\hline $\mathrm{Zn}^{+2}$ & 65 & $8.38 E+02$ & $1.84 E-04$ & -- & -- & -- & -- \\
\hline $\mathrm{AlO}_{2}^{-}$ & 59 & $3.38 E+06$ & $8.16 E-01$ & -- & $\cdots$ & $-\cdots$ & -- \\
\hline $\mathrm{Cl}^{-}$ & 35 & $3.29 E+05$ & 1.34 E-01 & -- & - & -- & -- \\
\hline $\mathrm{CO}_{3}^{-2}$ & 60 & $2.85 E+05$ & $6.77 E-02$ & -- & -- & -- & -- \\
\hline$F^{-}$ & 19 & $9.47 E+04$ & $7.10 E-02$ & - & -- & $\cdots$ & -- \\
\hline $\mathrm{Fe}(\mathrm{CN})_{6}{ }^{-3}$ & 212 & -- & -- & $=-$ & $\cdots$ & $=$ & -- \\
\hline $\mathrm{NO}_{2}{ }^{\prime}$ & 46 & $4.77 E+06$ & $1.48 E+00$ & -- & -- & -- & $\cdots$ \\
\hline $\mathrm{NO}_{3}^{+}$ & 62 & $9.26 E+06$ & $2.13 E+00$ & -- & -- & $3.37 E+05$ & $5.00 E-01$ \\
\hline $\mathrm{OH}^{-}$ & 17 & $4.22 E+06$ & $3.54 E+00$ & $=$ & -- & - & -- \\
\hline $\mathrm{PO}_{4}^{-3}$ & 95 & $3.55 E+04$ & $5.32 E-03$ & -- & - & $\cdots$ & $=-$ \\
\hline $\mathrm{SO}_{4}^{-2}$ & 96 & $1.27 E+05$ & $1.88 E-02$ & -- & -- & -- & $\cdots$ \\
\hline TOC & -- & $1.52 E+05$ & -- & -- & - & -- & $\cdots$ \\
\hline $\mathrm{MnO}_{2}$ & 87 & $7.95 E+02$ & 1.30 E-04 & -- & -- & -- & -- \\
\hline $\mathrm{H}_{2} \mathrm{O}$ & 18 & $6.50 E+07$ & -- & $8.16 E+05$ & $8.16 E+05$ & $1.07 \mathrm{E}+07$ & -- \\
\hline Total & -- & $1.00 E+08$ & $-\cdot$ & $8.16 E+05$ & $8.16 E+05$ & $1.10 E+07$ & -- \\
\hline
\end{tabular}

(a) Intermittent process stream.

(b) Includes all isotopes of cesium. 
Table 12-12. Cesium Ion Exchange, Double-Shell STurry

Feed, Resorcinol-Formaldehyde Resin, Major

Process Stream Data. (2 sheets)

\begin{tabular}{|c|c|c|c|c|c|c|}
\hline \multicolumn{2}{|c|}{ Stream number } & \multicolumn{2}{|c|}{540} & 150 & 550 & 447 \\
\hline \multicolumn{2}{|c|}{ Description } & \multicolumn{2}{|c|}{ Elution effluent } & $\begin{array}{l}\text { Post elution } \\
\text { water wash }\end{array}$ & $\begin{array}{c}\text { Post elution water } \\
\text { wash, column } \\
\text { effluent, HLW } \\
\text { portion }\end{array}$ & $\begin{array}{c}\text { Post elution water } \\
\text { wash, column } \\
\text { effluent, LLW } \\
\text { portion }\end{array}$ \\
\hline \multicolumn{2}{|c|}{$\begin{array}{l}\text { Temperature } \\
\left({ }^{\circ} \mathrm{C}\right)\end{array}$} & \multicolumn{2}{|c|}{25} & 25 & 25 & 25 \\
\hline \multicolumn{2}{|c|}{ Total volume (L) } & \multicolumn{2}{|c|}{$1.09 E+07$} & $1.09 E+06$ & $5.44 E+05$ & $5.44 E+05$ \\
\hline \multicolumn{2}{|c|}{$\begin{array}{l}\text { Instantaneous } \\
\text { design flow rate } \\
(\mathrm{L} / \mathrm{min})\end{array}$} & \multicolumn{2}{|c|}{$100^{(a)}$} & $200^{(a)}$ & $200^{(a)}$ & $200^{(a)}$ \\
\hline \multicolumn{2}{|l|}{$\mathrm{pH}$} & & & 7.00 & 7.00 & 7.00 \\
\hline \multicolumn{2}{|c|}{ Specific gravity } & \multicolumn{2}{|c|}{1.02} & 1.00 & 1.00 & 1.00 \\
\hline Component & $\mathrm{MW}$ & $\begin{array}{l}\text { Mass } \\
\text { (kgs) }\end{array}$ & $\underline{M}$ & $\begin{array}{l}\text { Mass } \\
\text { (kgs) }\end{array}$ & $\begin{array}{l}\text { Mass } \\
\text { (kgs) }\end{array}$ & $\begin{array}{l}\text { Mass } \\
\text { (kgs) }\end{array}$ \\
\hline$B^{.3}$ & 11 & -- & - & -- & - & - \\
\hline $\mathrm{Ba}^{-2}$ & 137 & -- & -- & - & -- & -- \\
\hline $\mathrm{Ca}^{\cdot 2}$ & 40 & -- & -- & -- & -- & $-\cdot$ \\
\hline $\mathrm{Cd}^{+2}$ & 112 & $-\cdot$ & -- & -- & -- & -- \\
\hline $\mathrm{Co}^{.3}$ & 59 & -- & -- & -- & -- & - \\
\hline$C s^{*(0)}$ & 134 & $5.44 E+02$ & $3.73 E-04$ & $\cdots$ & -- & -- \\
\hline $\mathrm{Cr}{ }^{* 3}$ & 52 & $-\cdot$ & -- & $\cdots$ & -- & -- \\
\hline $\mathrm{Cu}^{\prime 2}$ & 64 & -- & $\cdots$ & -- & -- & $-\cdot$ \\
\hline $\mathrm{Fe}^{.3}$ & 56 & -- & - & -- & -- & $-\cdot$ \\
\hline $\mathrm{H}^{+}$ & 1 & $4.59 E+03$ & $4.22 E-02$ & $\cdots$ & $-\cdot$ & -- \\
\hline $\mathrm{Hg}^{\cdot 2}$ & 201 & -- & $-\cdot$ & -- & -- & $\cdots$ \\
\hline $\mathrm{K}^{*}$ & 39 & $1.01 E+04$ & 2.38 E- 02 & -- & -- & -- \\
\hline $\mathrm{Mg}^{\cdot 2}$ & 24 & -- & -- & -- & -- & -- \\
\hline$M 0^{\circ}$ & 96 & -- & $\cdots$ & -- & -- & $\cdots$ \\
\hline $\mathrm{Na}^{*}$ & 23 & $1.25 E+04$ & $4.99 \mathrm{E}-02$ & $\cdots$ & -- & -- \\
\hline $\mathrm{Ni}^{+3}$ & 59 & $\cdots$ & -- & -- & -- & -- \\
\hline
\end{tabular}


Table 12-12. Cesium Ion Exchange, Double-Shell Slurry

Feed, Resorcinol-Formaldehyde Resin, Major

Process Stream Data. (2 sheets)

\begin{tabular}{|c|c|c|c|c|c|c|}
\hline \multicolumn{2}{|c|}{ Stream number } & \multicolumn{2}{|c|}{540} & 150 & 550 & 447 \\
\hline \multicolumn{2}{|c|}{ Description } & \multicolumn{2}{|c|}{ Elution effluent } & \multirow{2}{*}{$\begin{array}{l}\begin{array}{c}\text { Post elution } \\
\text { water wash }\end{array} \\
\begin{array}{c}\text { Mass } \\
\text { (kgs) }\end{array}\end{array}$} & \multirow{2}{*}{$\begin{array}{c}\begin{array}{c}\text { Post elution water } \\
\text { wash, column } \\
\text { effluent, HLW } \\
\text { portion }\end{array} \\
\begin{array}{c}\text { Mass } \\
\text { (kgs) }\end{array}\end{array}$} & \multirow{2}{*}{$\begin{array}{c}\begin{array}{c}\text { Post elution water } \\
\text { wash, column } \\
\text { effluent, LLW } \\
\text { portion }\end{array} \\
\begin{array}{c}\text { Mass } \\
\text { (kgs) }\end{array}\end{array}$} \\
\hline Component & MW & $\begin{array}{l}\text { Mass } \\
\text { (kgs) }\end{array}$ & $\underline{\mathrm{M}}$ & & & \\
\hline $\mathrm{Pb}^{* 4}$ & 207 & - & -- & $\cdots$ & - & -- \\
\hline $\begin{array}{l}\text { Rare } \\
\text { Earths } 3\end{array}$ & -- & $\cdots$ & -- & - & - & $\cdots$ \\
\hline $\mathrm{Rh}^{* 3}$ & 103 & $\cdots$ & -- & $\therefore$ & -- & -. \\
\hline $\mathrm{Ru}^{+3}$ & 101 & - & $\cdots$ & -- & -- & - \\
\hline $\mathrm{Si}^{+4}$ & 28 & $\cdots$ & -- & $\cdots$ & -- & -- \\
\hline $\mathrm{Ti}^{+4}$ & 48 & $\cdots$ & -. & $-\cdot$ & -- & - \\
\hline $\mathrm{UO}_{2}{ }^{\prime 2}$ & 270 & -- & - & $\cdots$ & $\cdots$ & -- \\
\hline $2 n^{+2}$ & 65 & -- & -- & - & -- & -- \\
\hline $\mathrm{AlO}_{2}^{-}$ & 59 & $\cdots$ & $\cdots$ & $\cdots$ & -- & -- \\
\hline $\mathrm{Cl}^{-}$ & 35 & -. & -- & $\cdots$ & -. & -- \\
\hline $\mathrm{CO}_{3}^{-2}$ & 60 & -- & $\cdots$ & - & -- & -- \\
\hline$F^{-}$ & 19 & $\cdots$ & -- & -- & -. & -- \\
\hline $\mathrm{Fe}(\mathrm{CN})_{6}{ }^{-3}$ & 212 & -- & -- & $\cdots$ & -- & - - \\
\hline $\mathrm{NO}_{2}^{-}$ & 46 & - & -- & $\cdots$ & $\cdots$ & -- \\
\hline $\mathrm{NO}_{3}^{-}$ & 62 & $3.37 E+05$ & $5.00 E-01$ & -- & $\cdots$ & -- \\
\hline $\mathrm{OH}^{-}$ & 17 & - & -- & $\cdots$ & $\cdots$ & -- \\
\hline $\mathrm{PO}_{4}^{-3}$ & 95 & $\cdots$ & -- & -- & - & -- \\
\hline $\mathrm{SO}_{4}^{-2}$ & 96 & - & -- & - & -- & -- \\
\hline TOC & -- & $\cdots$ & -- & -- & -. & -- \\
\hline $\mathrm{MnO}_{2}$ & 87 & -- & $\cdots$ & $\cdots$ & -- & $\cdots$ \\
\hline $\mathrm{H}_{2} \mathrm{O}$ & 18 & $1.07 E+07$ & -- & $1.09 E+06$ & $5.44 E+05$ & $5.44 E+05$ \\
\hline Total & $\cdots$ & $1.11 E+07$ & $\cdots$ & $1.09 E+06$ & $5.44 E+05$ & $5.44 E+05$ \\
\hline
\end{tabular}

(a) Intermittent process stream.

(b) Includes all isotopes of cesium. 
Table 12-13. Gesium Ion Exchange, Double-She11 Slurry

Feed, Resorcinol-Formaldehyde Resin, Major Process Stream Data. (2 sheets)

\begin{tabular}{|c|c|c|c|c|c|c|}
\hline \multicolumn{2}{|c|}{ Stream number } & \multicolumn{2}{|c|}{231} & 441 & \multicolumn{2}{|c|}{233} \\
\hline \multicolumn{2}{|c|}{ Description } & \multicolumn{2}{|c|}{ First regeneration } & $\begin{array}{c}\text { First regeneration } \\
\text { ef fluent }\end{array}$ & \multicolumn{2}{|c|}{$\begin{array}{l}\text { Second } \\
\text { regeneration }\end{array}$} \\
\hline \multicolumn{2}{|c|}{ Temperature $\left({ }^{\circ} \mathrm{C}\right)$} & \multicolumn{2}{|c|}{25} & 25 & \multicolumn{2}{|c|}{25} \\
\hline \multicolumn{2}{|c|}{ Total volume (L) } & \multicolumn{2}{|c|}{$2.18 E+06$} & $2.18 E+06$ & \multicolumn{2}{|c|}{$1.63 E+06$} \\
\hline \multicolumn{2}{|c|}{$\begin{array}{l}\text { Instantaneous design } \\
\text { flow rate }(L / m i n)\end{array}$} & \multicolumn{2}{|c|}{$100^{(a)}$} & $100^{(a)}$ & \multicolumn{2}{|c|}{$100^{(a)}$} \\
\hline \multicolumn{2}{|l|}{$\mathrm{pH}$} & \multicolumn{2}{|c|}{$13+$} & $13+$ & \multicolumn{2}{|c|}{$13+$} \\
\hline \multicolumn{2}{|c|}{ Specific gravity } & \multicolumn{2}{|c|}{1.00} & 1.00 & \multicolumn{2}{|c|}{1.05} \\
\hline Component & MW & $\begin{array}{l}\text { Mass } \\
(\mathrm{kgs})\end{array}$ & $\underline{M}$ & $\begin{array}{l}\text { Mass } \\
\text { (kgs) }\end{array}$ & $\begin{array}{l}\text { Mass } \\
\text { (kgs) }\end{array}$ & $\underline{M}$ \\
\hline$B^{+3}$ & 11 & $-\cdot$ & $\cdots$ & -- & -- & -- \\
\hline $\mathrm{Ba}^{.2}$ & 137 & -- & -- & -- & $-\cdot$ & $\cdot-$ \\
\hline $\mathrm{Ca}^{2}$ & 40 & $-\cdot$ & -- & -- & -- & -- \\
\hline $\mathrm{Cd}^{+2}$ & 112 & $\cdots$ & -- & -- & -- & -- \\
\hline $\mathrm{CO}^{+3}$ & 59 & -- & -- & -- & -- & $-\cdot$ \\
\hline$C s^{+(b)}$ & 134 & -- & -- & -- & -- & -- \\
\hline $\mathrm{Cr}{ }^{3}$ & 52 & -- & -- & -- & -- & -- \\
\hline $\mathrm{Cu}^{.2}$ & 64 & -- & -- & -- & -- & -- \\
\hline $\mathrm{Fe}^{.3}$ & 56 & $-\cdot$ & -- & -- & -- & $-\cdot$ \\
\hline $\mathrm{H}^{*}$ & 1 & -- & $\because$ & -- & $\cdots$ & -- \\
\hline $\mathrm{Hg}^{.2}$ & 201 & $-\cdot$ & -- & -- & $-\cdot$ & - \\
\hline$K^{*}$ & 39 & $\cdots$ & -- & $\cdots$ & $-\cdot$ & $-\cdot$ \\
\hline $\mathrm{Mg}^{* 2}$ & 24 & -- & -- & -- & -- & -- \\
\hline $\mathrm{Mo}^{\circ 6}$ & 96 & -- & $-\cdot$ & $\cdots$ & $\cdots$ & $\cdots$ \\
\hline $\mathrm{Na}^{*}$ & 23 & $2.50 E+04$ & 5.00 E-01 & $5.38 E+03$ & $7.51 E+04$ & $2.00 E+00$ \\
\hline $\mathrm{Ni}^{3}$ & 59 & -- & -- & -- & -- & -- \\
\hline
\end{tabular}


Table 12-13. Cesium Ion Exchange, Double-Shell Slurry Feed, Resorcinol-Formaldehyde Resin, Major Process Stream Data. (2 sheets)

\begin{tabular}{|c|c|c|c|c|c|c|}
\hline \multicolumn{2}{|c|}{ stream number } & \multicolumn{2}{|c|}{231} & \multirow{2}{*}{ 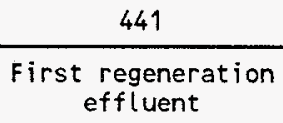 } & \multicolumn{2}{|c|}{233} \\
\hline \multicolumn{2}{|c|}{ Description } & \multicolumn{2}{|c|}{ First regeneration } & & \multicolumn{2}{|c|}{$\begin{array}{l}\text { Second } \\
\text { regeneration }\end{array}$} \\
\hline Component & MW & $\begin{array}{l}\text { Mass } \\
\text { (kgs) }\end{array}$ & $\underline{M}$ & $\begin{array}{l}\text { Mass } \\
\text { (kgs) }\end{array}$ & $\begin{array}{l}\text { Mass } \\
\text { (kgs) }\end{array}$ & $\underline{M}$ \\
\hline $\mathrm{Pb}^{+4}$ & 207 & - & -- & - & - & -- \\
\hline Rare Earths ${ }^{* *}$ & -- & -- & - & $=$ & -- & -- \\
\hline $\mathrm{Rh}^{+3}$ & 103 & -- & - & -- & -- & -- \\
\hline $\mathrm{Ru}^{+3}$ & 101 & - & -- & -- & -- & - \\
\hline $\mathrm{Si}^{+4}$ & 28 & -- & $\cdots$ & $\cdots$ & $\cdots$ & - \\
\hline $\mathrm{Ti}^{+4}$ & 48 & -- & $\cdots$ & - & -- & -- \\
\hline $\mathrm{UO}_{2}^{* 2}$ & 270 & -- & -- & $\cdots$ & -- & $\cdots$ \\
\hline $\mathrm{Zn}^{+2}$ & 65 & -- & -- & - & -- & -- \\
\hline $\mathrm{AlO}_{2}^{-}$ & 59 & $-\cdots$ & - - & -- & - & - \\
\hline $\mathrm{Cl}^{-}$ & 35 & -- & -- & - & $\therefore$ & - \\
\hline $\mathrm{CO}_{3}^{-2}$ & 60 & -- & -- & - & $-\cdot$ & -- \\
\hline$F^{-}$ & 19 & -- & -- & -- & - & - \\
\hline $\mathrm{Fe}(\mathrm{CN})_{6}{ }^{-3}$ & 212 & -- & -- & -- & -- & $\ldots$ \\
\hline $\mathrm{NO}_{2}^{-}$ & 46 & -- & - - & $=$ & -- & $\cdots$ \\
\hline $\mathrm{NO}_{3}^{-}$ & 62 & -- & -- & -- & - & -- \\
\hline $\mathrm{OH}^{-}$ & 17 & $1.85 E+04$ & $5.00 E-01$ & $3.98 E+03$ & $5.55 E+04$ & $2.00 E+00$ \\
\hline $\mathrm{PO}_{4}^{-3}$ & 95 & -- & $\cdots$ & -- & -- & -- \\
\hline $\mathrm{SO}_{4}^{-2}$ & 96 & -- & - - & - & -- & $\cdots$ \\
\hline TOC & -- & -- & -- & - & $\ldots$ & $\cdots$ \\
\hline $\mathrm{MnO}_{2}$ & 87 & $=-$ & -- & $=$ & $\cdots$ & -- \\
\hline $\mathrm{H}_{2} \mathrm{O}$ & 18 & 2. $17 E+06$ & -- & $2.19 E+06$ & $1.58 E+06$ & $\cdots$ \\
\hline Total & $\cdots$ & $2.22 E+06$ & $\therefore$ & $2.20 E+06$ & $1.72 E+06$ & - \\
\hline
\end{tabular}

(a) Intermittent process stream.

(b) Includes all isotopes of cesium. 
Table 12-14. Cesium Ion Exchange, Double-Shell Slurry Feed, Resorcinol-Formaldehyde Resin, Major

Process Stream Data. (2 sheets)

\begin{tabular}{|c|c|c|c|c|c|c|}
\hline \multicolumn{2}{|c|}{ Stream number } & \multicolumn{2}{|c|}{443} & \multicolumn{2}{|c|}{455} & 166 \\
\hline \multicolumn{2}{|c|}{ Description } & \multicolumn{2}{|c|}{$\begin{array}{c}\text { Second regeneration } \\
\text { effluent }\end{array}$} & \multicolumn{2}{|c|}{ Post Cs-IX evaporator LLW feed } & $\begin{array}{l}\text { Post Cs-IX } \\
\text { evaporator } \\
\text { overheads }\end{array}$ \\
\hline \multicolumn{2}{|c|}{$\begin{array}{c}\text { Temperature } \\
\left({ }^{\circ} \mathrm{C}\right)\end{array}$} & \multicolumn{2}{|c|}{25} & \multicolumn{2}{|c|}{-25} & 100 \\
\hline \multicolumn{2}{|c|}{ Total volume (L) } & \multicolumn{2}{|c|}{$1.63 E+06$} & \multicolumn{2}{|c|}{$7.54 E+07$} & $2.58 E+07$ \\
\hline \multicolumn{2}{|c|}{$\begin{array}{l}\text { Instantaneous } \\
\text { design flow rate } \\
\text { (L/min) }\end{array}$} & \multicolumn{2}{|c|}{$100^{(a)}$} & \multicolumn{2}{|c|}{-} & - \\
\hline \multicolumn{2}{|l|}{ pH } & \multicolumn{2}{|c|}{$13+$} & \multicolumn{2}{|c|}{$13+$} & 7.00 \\
\hline \multicolumn{2}{|c|}{ Specific gravity } & \multicolumn{2}{|c|}{1.04} & \multicolumn{2}{|c|}{1.33} & 1.00 \\
\hline Component & MW & $\begin{array}{l}\text { Mass } \\
\text { (kgs) }\end{array}$ & $\underline{M}$ & $\begin{array}{l}\text { Mass } \\
\text { (kgs) }\end{array}$ & M & $\begin{array}{l}\text { Mass } \\
(\mathrm{kgs})\end{array}$ \\
\hline$B^{* 3}$ & 11 & -- & - & $1.29 E+01$ & 1.56 E-05 & -- \\
\hline $\mathrm{Ba}^{22}$ & 137 & - & - & $2.98 E+02$ & $2.89 E-05$ & -- \\
\hline $\mathrm{Ca}^{\cdot 2}$ & 40 & -- & $\cdots$ & $3.34 E+03$ & $1.11 E-03$ & -- \\
\hline $\mathrm{Cd}^{2}$ & 112 & - & -- & $2.79 E+02$ & $3.31 E-05$ & $\cdots$ \\
\hline $\mathrm{Co}^{.3}$ & 59 & -- & -- & 1.09 E-03 & $2.45 E-10$ & $\cdots$ \\
\hline $\mathrm{Cs}^{+(\mathrm{b})}$ & 134 & - & - & $1.30+00$ & $1.29 E-07$ & -- \\
\hline $\mathrm{Cr}^{+3}$ & 52 & -- & -- & $2.30 E+04$ & 5.87 E-03 & -- \\
\hline $\mathrm{Cu}^{\prime 2}$ & 64 & -. & -- & $2.09 E+02$ & $4.33 E-05$ & -- \\
\hline $\mathrm{Fe}^{+3}$ & 56 & $\cdots$ & -- & $1.13 E+03$ & $2.68 E-04$ & -- \\
\hline $\mathrm{H}^{+}$ & 1 & -- & -- & 0 & 0 & - \\
\hline $\mathrm{Hg}^{22}$ & 201 & $\cdots$ & $-\cdot$ & $-\cdot$ & $\cdots$ & -- \\
\hline $\mathrm{K}^{*}$ & 39 & $\cdots$ & -- & $1.31 E+06$ & $4.46 E-01$ & $\cdots$ \\
\hline $\mathrm{Mg}^{\circ 2}$ & 24 & $\cdots$ & -- & $5.23 E+02$ & $2.89 E-04$ & $-\cdot$ \\
\hline $\mathrm{Mo}^{+6}$ & 96 & -. & -- & $2.77 E+03$ & 3.38 E-04 & -- \\
\hline $\mathrm{Na}^{*}$ & 23 & $7.51 E+04$ & $2.00 E+00$ & $1.14 \varepsilon+07$ & $6.57 E+00$ & $\cdots$ \\
\hline $\mathrm{Ni}^{* 3}$ & 59 & -- & - & $5.61 E+02$ & 1.26 E-04 & $\cdots$ \\
\hline
\end{tabular}


Table 12-14. Cesium Ion Exchange, Double-She17. S7urry Feed, Resorcinol-Formaldehyde Resin, Major Process Stream Data. (2 sheets)

\begin{tabular}{|c|c|c|c|c|c|c|}
\hline \multicolumn{2}{|c|}{ Stream number } & \multicolumn{2}{|c|}{443} & \multicolumn{2}{|c|}{455} & 166 \\
\hline \multicolumn{2}{|c|}{ Description } & \multicolumn{2}{|c|}{$\begin{array}{c}\text { Second regeneration } \\
\text { Effluent }\end{array}$} & \multicolumn{2}{|c|}{ Post Cs-IX evaporator LLW feed } & $\begin{array}{l}\text { Post Cs-IX evapo- } \\
\text { rator overheads }\end{array}$ \\
\hline Component & MW & $\begin{array}{l}\text { Mass } \\
(\mathrm{kgs})\end{array}$ & $\underline{M}$ & $\begin{array}{l}\text { Mass } \\
\text { (kgs) }\end{array}$ & $\underline{M}$ & $\begin{array}{l}\text { Mass } \\
\text { (kgs) }\end{array}$ \\
\hline $\mathrm{Pb}^{* 4}$ & 207 & -- & - & $2.65 E+03$ & $1.70 E-04$ & -- \\
\hline $\begin{array}{l}\text { Rare } \\
\text { Earths } * 3\end{array}$ & -. & $\cdots$ & -- & $5.16 \mathrm{E}-01$ & -- & -- \\
\hline $\mathrm{Rh}^{+3}$ & 103 & -- & $\cdots$ & $1.28 E+00$ & $1.65 E-07$ & -- \\
\hline $\mathrm{Ru}^{\cdot 3}$ & 101 & -- & -- & $6.17 E-01$ & $8.11 E-08$ & -- \\
\hline $\mathrm{Si}^{+4}$ & 28 & -- & -- & $8.12 E+03$ & $3.85 E-03$ & -- \\
\hline$T i^{+4}$ & 48 & $\cdots$ & $\cdots$ & $1.46 E+00$ & $4.04 E-07$ & -- \\
\hline $\mathrm{UO}_{2}^{+2}$ & 270 & + & -- & $7.88 E+03$ & $3.88 \mathrm{E}-04$ & -- \\
\hline $2 n^{2}$ & 65 & - & $\cdots$ & $8.38 \mathrm{E}+02$ & 1.71 E-04 & $-\cdot$ \\
\hline $\mathrm{AlO}_{2}^{-}$ & 59 & -- & $-\cdot$ & $3.38 \mathrm{E}+06$ & 7.60 E-01 & -- \\
\hline $\mathrm{Cl}^{-}$ & 35 & $\cdots$ & -- & $3.29 E+05$ & $1.25 E-01$ & -- \\
\hline $\mathrm{CO}_{3}^{-2}$ & 60 & -- & -- & $2.85 E+05$ & $6.30 \varepsilon-02$ & $-\cdot$ \\
\hline$F^{-}$ & 19 & - - & - & $9.47 E+04$ & $6.61 E-02$ & -- \\
\hline $\mathrm{Fe}(\mathrm{CN})_{6}^{-3}$ & 212 & $\cdots$ & -- & - & - & -- \\
\hline $\mathrm{NO}_{2}^{-}$ & 46 & -- & -- & $4.77 E+06$ & $1.38 E+00$ & -- \\
\hline $\mathrm{NO}_{3}^{-}$ & 62 & $\cdots$ & -- & $9.26 E+06$ & $1.98 E+00$ & -- \\
\hline $\mathrm{OH}^{-}$ & 17 & $5.55 \varepsilon+04$ & $2.00 E+00$ & $4.29 E+06$ & $3.35 E+00$ & -- \\
\hline $\mathrm{PO}_{4}{ }^{-3}$ & 95 & $\cdots$ & -- & $3.55 E+04$ & $4.96 E-03$ & $\cdots$ \\
\hline $\mathrm{SO}_{4}{ }^{-2}$ & 96 & -- & -- & $1.27 E+05$ & $1.76 \mathrm{E}-02$ & -- \\
\hline TOC & -- & -- & -. & $1.52 E+05$ & $-\cdot$ & -- \\
\hline $\mathrm{MnO}_{2}$ & 87 & -- & -- & $7.95 \mathrm{E}+02$ & $1.21 E-04$ & $-\cdot$ \\
\hline $\mathrm{H}_{2} \mathrm{O}$ & 18 & $1.58 E+06$ & -- & $7.01 \mathrm{E}+07$ & $\cdots$ & $2.58 E+07$ \\
\hline Total & -- & $1.72 E+06$ & -- & $1.06 E+08$ & -. & $2.58 E+07$ \\
\hline
\end{tabular}

(a) Intermittent process stream.

(b) Ineludes all isotopes of cesium. 
Table 12-15. Cesium Ion Exchange, Double-Shell Slurry

Feed, Resorcinol-Formaldehyde Resin, Major

Process Stream Data. (2 sheets)

\begin{tabular}{|c|c|c|c|c|c|}
\hline \multicolumn{2}{|c|}{ Stream number } & \multicolumn{2}{|c|}{470} & \multicolumn{2}{|c|}{560} \\
\hline \multicolumn{2}{|c|}{ Description } & \multicolumn{2}{|c|}{ LLW glass feed } & \multicolumn{2}{|c|}{ Eluate Concentrator Feed } \\
\hline \multicolumn{2}{|c|}{ Temperature $\left({ }^{\circ} \mathrm{C}\right)$} & \multicolumn{2}{|c|}{60} & \multicolumn{2}{|c|}{25} \\
\hline \multicolumn{2}{|c|}{ Total volume (L) } & \multicolumn{2}{|c|}{$4.96 E+07$} & \multicolumn{2}{|c|}{$1.14 E+07$} \\
\hline \multicolumn{2}{|c|}{$\begin{array}{l}\text { Instantaneous design } \\
\text { flow rate (L/min) }\end{array}$} & \multicolumn{2}{|c|}{--} & \multicolumn{2}{|c|}{$\cdots$} \\
\hline \multicolumn{2}{|l|}{ pH } & \multicolumn{2}{|c|}{--} & \multicolumn{2}{|c|}{--} \\
\hline \multicolumn{2}{|c|}{ Specific gravity } & \multicolumn{2}{|c|}{1.98} & \multicolumn{2}{|c|}{1.02} \\
\hline Component & MW & $\begin{array}{l}\text { Mass } \\
(\mathrm{kgs})\end{array}$ & $\underline{M}$ & $\begin{array}{l}\text { Mass } \\
\text { (kgs) }\end{array}$ & $\underline{M}$ \\
\hline$B^{+3}$ & 11 & $1.29 \mathrm{E}+01$ & $2.37 \mathrm{E}-05$ & -- & -- \\
\hline $\mathrm{Ba}^{* 2}$ & 137 & $2.98 E+02$ & $4.39 E-05$ & -- & - \\
\hline $\mathrm{Ca}^{-2}$ & 40 & $3.34 \varepsilon+03$ & $1.68 E-03$ & -- & -- \\
\hline $\mathrm{Cd}^{+2}$ & 112 & $2.79 E+02$ & $5.03 \mathrm{E}-05$ & $\cdots$ & -- \\
\hline $\mathrm{CO}^{-3}$ & 59 & $1.09 E-03$ & $3.73 E-10$ & -- & -- \\
\hline$C s^{*(a)}$ & 134 & $1.30 E+00$ & $1.96 \mathrm{E}-07$ & $5.44 E+02$ & $3.55 E-04$ \\
\hline $\mathrm{Cr}^{+3}$ & 52 & $2.30 E+04$ & 8.92 E-03 & $\cdots$ & -- \\
\hline $\mathrm{Cu}^{-2}$ & 64 & $2.09 E+02$ & $6.59 \mathrm{E}-05$ & $\cdots$ & $-\cdot$ \\
\hline $\mathrm{Fe}^{+3}$ & 56 & $1.13 E+03$ & $4.07 \mathrm{E}-04$ & $\cdots$ & -- \\
\hline $\mathrm{H}^{+}$ & 1 & 0 & 0 & $4.59 E+03$ & $4.01 \mathrm{E}-01$ \\
\hline $\mathrm{Hg}^{2}$ & 201 & -- & -- & $\cdots$ & -. \\
\hline$K^{*}$ & 39 & $1.31 E+06$ & $6.78 E-01$ & $1.01 E+04$ & $2.27 E-02$ \\
\hline $\mathrm{Mg}^{\prime 2}$ & 24 & $5.23 E+02$ & 4.40 E- 04 & $-\cdot$ & $-\cdot$ \\
\hline $\mathrm{Mo}^{+6}$ & 96 & $2.77 E+03$ & 5.82 E-04 & -- & -- \\
\hline $\mathrm{Na}^{+}$ & 23 & $1.14 E+07$ & $1.00 E+01$ & $1.25 E+04$ & 4.75 E-02 \\
\hline $\mathrm{Ni}^{+3}$ & 59 & $5.61 E+02$ & $1.92 \mathrm{E}-04$ & -- & - \\
\hline
\end{tabular}


Table 12-15. Cesium Ion Exchange, Double-She11 Slurry Feed, Resorcinol-Formaldehyde Resin, Major Process Stream Data. (2 sheets)

\begin{tabular}{|c|c|c|c|c|c|}
\hline \multicolumn{2}{|c|}{ Stream number } & \multicolumn{2}{|c|}{470} & \multicolumn{2}{|c|}{560} \\
\hline \multicolumn{2}{|c|}{ Description } & \multicolumn{2}{|c|}{ LLW Glass Feed } & \multicolumn{2}{|c|}{ Eluate Concentrator Feed } \\
\hline Component & MW & $\begin{array}{l}\text { Mass } \\
\text { (kgs) }\end{array}$ & $\underline{M}$ & $\begin{array}{l}\text { Mass } \\
\text { (kgs) }\end{array}$ & $\underline{M}$ \\
\hline $\mathrm{Pb}^{\cdot 4}$ & 207 & $2.65 E+03$ & $2.58 E-04$ & -- & -- \\
\hline Rare Earths ${ }^{+3}$ & -- & $5.16 E-01$ & -- & - & - \\
\hline $\mathrm{Rh}^{\cdot 3}$ & 103 & $1.28 E+00$ & $2.51 E-07$ & -- & - \\
\hline $\mathrm{Ru}^{+3}$ & 101 & $6.17 E-01$ & $1.23 \mathrm{E}-07$ & -- & -- \\
\hline $\mathrm{Si}^{.4}$ & 28 & $8.12 E+03$ & $5.85 E-03$ & $\cdots$ & $\cdots$ \\
\hline $\mathrm{Ti}^{+4}$ & 48 & $1.46 E+00$ & $6.14 E-07$ & $\cdots$ & -- \\
\hline $\mathrm{UO}_{2}{ }^{-2}$ & 270 & $7.88 E+03$ & $5.89 E-04$ & -- & -- \\
\hline $2 n^{+2}$ & 65 & $8.38 E+02$ & $2.60 E-04$ & $\cdots$ & -- \\
\hline $\mathrm{AlO}_{2}^{-}$ & 59 & $3.38 E+06$ & $1.16 E+00$ & -. & -- \\
\hline $\mathrm{Cl}^{-}$ & 35 & $3.29 E+05$ & $1.90 E-01$ & -- & -- \\
\hline $\mathrm{CO}_{3}^{-2}$ & 60 & $2.85 E+05$ & $9.58 E-02$ & -- & -- \\
\hline$F^{-}$ & 19 & $9.47 E+04$ & 1.00 E-01 & -- & - - \\
\hline $\mathrm{Fe}(\mathrm{CN})_{5}^{-3}$ & 212 & -- & -- & -- & -- \\
\hline $\mathrm{NO}_{2}^{-}$ & 46 & $4.77 E+06$ & $2.09 E+00$ & -- & -- \\
\hline $\mathrm{NO}_{3}^{-}$ & 62 & $9.26 E+06$ & $3.01 E+00$ & $3.37 E+05$ & $4.76 \mathrm{E}-01$ \\
\hline $\mathrm{OH}^{-}$ & 17 & $4.29 E+06$ & $5.08 E+00$ & - & -- \\
\hline $\mathrm{PO}_{q}^{-3}$ & 95 & $3.55 E+04$ & 7.54 E-03 & 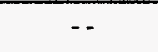 & -- \\
\hline $\mathrm{SO}_{4}^{-2}$ & 96 & $1.27 E+05$ & 2.67 E-02 & $\cdots$ & $\cdots$ \\
\hline TOC & $\cdots$ & $1.52 E+05$ & -- & -- & -- \\
\hline $\mathrm{MnO}_{2}$ & 87 & $7.95 E+02$ & 1.84 E-04 & $\cdots$ & . - \\
\hline $\mathrm{H}_{2} \mathrm{O}$ & 18 & $4.43 E+07$ & - & $1.12 E+07$ & - - \\
\hline Total & $\ldots$ & $7.98 E+07$ & -. & $1.16 E+07$ & -. \\
\hline
\end{tabular}

(a) Includes all isotopes of cesium. 
Table 12-16. Cesium Ion Exchange, Double-She11 Slurry Feed, Resorcinol-Formaldehyde Resin, Major Process Stream Data. (2 sheets)

\begin{tabular}{|c|c|c|c|c|c|c|}
\hline \multicolumn{2}{|c|}{ stream number } & \multicolumn{2}{|c|}{380} & 565 & 280 & 570 \\
\hline \multicolumn{2}{|c|}{ Description } & \multicolumn{2}{|c|}{$\begin{array}{c}\text { Eluate concentrator } \\
\text { overheads }\end{array}$} & $\begin{array}{l}\text { Eluate } \\
\text { concentrator } \\
\text { Bottoms }\end{array}$ & $\begin{array}{c}\text { Eluate } \\
\text { neutral ization } \\
\text { solution }\end{array}$ & Neutralized eluate \\
\hline \multicolumn{2}{|c|}{$\begin{array}{l}\text { Temperature } \\
\left({ }^{\circ} \mathrm{C}\right)\end{array}$} & \multicolumn{2}{|c|}{25} & 25 & 25 & 25 \\
\hline \multicolumn{2}{|c|}{ Total volume $(L)$} & \multicolumn{2}{|c|}{$1.06 E+07$} & $2.57 E+05$ & $1.25 E+05$ & $3.87 E+05$ \\
\hline \multicolumn{2}{|c|}{$\begin{array}{l}\text { Instantaneous } \\
\text { design flow rate } \\
\text { (L/min) }\end{array}$} & \multicolumn{2}{|c|}{25} & 3 & 1 & 4 \\
\hline \multicolumn{2}{|l|}{ pH } & \multicolumn{2}{|c|}{$<1.0$} & $<1.0$ & $>13$ & $>13$ \\
\hline \multicolumn{2}{|c|}{ Specific gravity } & \multicolumn{2}{|c|}{1.01} & 1.3 & 1.4 & 1.3 \\
\hline Component & MW. & \multicolumn{2}{|l|}{$\begin{array}{l}\text { mass } \\
(\mathrm{kgs})\end{array}$} & $\begin{array}{l}\text { mass } \\
\text { (kgs) }\end{array}$ & $\begin{array}{l}\text { mass } \\
(\mathrm{kgs})\end{array}$ & $\begin{array}{l}\text { mass } \\
\text { (kgs) }\end{array}$ \\
\hline$B^{-3}$ & 11 & -- & -- & -- & -- & -- \\
\hline$B a^{.2}$ & 137 & -- & $\cdots$ & $\cdots$ & -- & -- \\
\hline $\mathrm{Ca}^{* 2}$ & 40 & -- & $\cdots$ & -- & -- & -- \\
\hline $\mathrm{Cd}^{+2}$ & 112 & -. & $-\cdot$ & -- & - & - \\
\hline $\mathrm{Co}^{+3}$ & 59 & -- & $-\cdot$ & -- & -- & -- \\
\hline $\mathrm{Cs}^{*(3)}$ & 134 & trace & $\cdots$ & $5.44 E+02$ & $\cdots$ & $5.44 E+02$ \\
\hline $\mathrm{Cr}^{\cdot 3}$ & 52 & -- & -. & -- & -- & - \\
\hline $\mathrm{Cu}^{+2}$ & 64 & -- & -- & $-\cdot$ & -- & -- \\
\hline $\mathrm{Fe}^{+3}$ & 56 & -- & - & -- & -- & -- \\
\hline $\mathrm{H}^{*}$ & 1 & $3.21 E+03$ & $2.05 E-01$ & $1.38 E+03$ & $\cdots$ & $\cdots$ \\
\hline $\mathrm{Hg}^{2}$ & 201 & -- & $\cdots$ & -- & $\cdots$ & $-\cdot$ \\
\hline $\mathrm{K}^{+}$ & 39 & $-\cdot$ & $-\cdot$ & $1.01 E+04$ & $-\cdot$ & $1.01 E+02$ \\
\hline $\mathrm{Mg}^{2}$ & 24 & -- & -- & -- & -- & -- \\
\hline $\mathrm{Mo}^{+6}$ & 96 & $-\cdot$ & $\cdots$ & -- & $\cdots$ & $\cdots$ \\
\hline $\mathrm{Na}^{+}$ & 23 & -- & -- & $1.29 E+04$ & $4.26 E+04$ & $5.51 E+04$ \\
\hline $\mathrm{Ni}^{+3}$ & 59 & -- & $-\cdot$ & -- & -- & - \\
\hline
\end{tabular}


Table 12-16. Cesium Ion Exchange, Double-Shell Slurry

Feed, Resorcinol-Formaldehyde Resin, Major Process Stream Data. (2 sheets)

\begin{tabular}{|c|c|c|c|c|c|c|}
\hline \multicolumn{2}{|c|}{ Stream number } & \multicolumn{2}{|c|}{380} & 565 & 280 & 570 \\
\hline \multicolumn{2}{|c|}{ Description } & \multicolumn{2}{|c|}{$\begin{array}{c}\text { Eluate concentrator } \\
\text { overheads }\end{array}$} & $\begin{array}{c}\text { Eluate } \\
\text { concentrator } \\
\text { bottoms }\end{array}$ & $\begin{array}{c}\text { Eluate neutraliza- } \\
\text { tion solution }\end{array}$ & Neutral ized eluate \\
\hline Component & MW & $\begin{array}{l}\text { mass } \\
\text { (kgs) }\end{array}$ & $\underline{M}$ & $\begin{array}{l}\text { mass } \\
(\mathrm{kgs})\end{array}$ & $\begin{array}{l}\text { mass } \\
\text { (kgs) }\end{array}$ & $\begin{array}{l}\text { mass } \\
\text { (kgs) }\end{array}$ \\
\hline $\mathrm{Pb}^{\cdot 4}$ & 207 & -- & -- & -- & -- & $\cdots$ \\
\hline $\begin{array}{l}\text { Rare } \\
\text { Earths }+3\end{array}$ & -- & -- & - & -- & - & -- \\
\hline $\mathrm{Rh}^{* 3}$ & 103 & -- & -- & - & - & -- \\
\hline $\mathrm{Ru}^{\cdot 3}$ & 101 & $\cdots$ & $-\cdot$ & $\cdots$ & -- & - \\
\hline $\mathrm{Si}^{\cdot 4}$ & 28 & -- & - & $\cdots$ & -- & $\cdots$ \\
\hline$T i^{+4}$ & 48 & -- & -- & $\cdots$ & & -- \\
\hline $\mathrm{UD}_{2} \cdot 2$ & 270 & $\cdots$ & -- & -- & - & $\cdots$ \\
\hline $\mathrm{Zn}^{+2}$ & 65 & -- & -- & $\cdots$ & -- & -- \\
\hline $\mathrm{AlO}_{2}^{-}$ & 59 & -- & - & $\cdots$ & - & $\cdots$ \\
\hline $\mathrm{Cl}^{-}$ & 35 & -- & - & -- & -- & -- \\
\hline $\mathrm{CO}_{3}^{-2}$ & 60 & -- & -- & $\cdots$ & -- & -- \\
\hline$F^{-}$ & 19 & $\cdots$ & -- & -- & -- & $-\cdot$ \\
\hline $\mathrm{Fe}(\mathrm{CN})_{6}^{-3}$ & 212 & $-\cdot$ & -- & -- & $\cdots$ & -- \\
\hline $\mathrm{NO}_{2}^{-}$ & 46 & - & -- & $\cdots$ & $1.60 E+04$ & $1.60 E+04$ \\
\hline $\mathrm{NO}_{3}^{-}$ & 62 & $1.94 E+05$ & $2.05 \mathrm{E}-01$ & $1.38 E+05$ & -- & $1.38 E+05$ \\
\hline $\mathrm{OH}^{-}$ & 17 & $\cdots$ & $=-$ & $\cdots$ & $2.55 E+04$ & $2.15 E+03$ \\
\hline $\mathrm{PO}_{4}{ }^{-3}$ & 95 & $\cdots$ & -- & -- & - & -- \\
\hline $\mathrm{SO}_{4}^{-2}$ & 96 & -- & -- & $\cdots$ & $-\cdot$ & -- \\
\hline TOC & $\cdots$ & -- & - & $\cdots$ & -- & -- \\
\hline $\mathrm{MnO}_{2}$ & 87 & $\cdots$ & $-\cdot$ & $-\cdot$ & -- & - \\
\hline $\mathrm{H}_{2} \mathrm{O}$ & 18 & $1.05 E+07$ & -- & $1.60 E+06$ & $9.62 \mathrm{E}+04$ & $2.84 E+05$ \\
\hline Total & -- & $1.07 E+07$ & -- & $3.23 E+05$ & $1.80 \mathrm{E}+05$ & $5.12 E+05$ \\
\hline
\end{tabular}

${ }^{(a)}$ Includes all isotopes of cesium. 


\subsection{ISSUES AND CONCERNS}

\section{I GENERAL ISSUES}

Separation requirements for this process are extremely high $(99.99 \%$ cesium removal required for NCAW). This is exemplified by the requirement that of the original $340 \mathrm{~kg}$ of cesium in NCAW only $40 \mathrm{~g}$ can be permitted to pass into the LLW glass and still meet the class A specifications. Cesium separation factors of this type (cesium DFs of 10,000 to 100,000) from high alkaline waste were achieved consistently with the West Valley Supernate Treatment System. The West Valley system however was not a regenerable system.

The system performance will vary with the feed sent to it. The cesium removal capacity of the resin is significantly different with the NCAW and DSSF wastes. It will also vary with other types of wastes and differences in concentrations of chemicals and ratios of chemical concentrations. The ion exchange process will require continuous monitoring and careful process control to achieve the required results. Loading and elution models being developed by PNL which will be completed in the future may help in predicting how to control the IX system.

Careful attention must be given to all aspects of both design and operation if the waste is to be treated and meet the proposed treatment requirements.

\subsection{ISSUES ASSOCIATED WITH THE RESORCINOL- FORMALDEHYDE RESIN}

\subsubsection{Clumping of Resorcinol-Formaldehyde Resin}

There are several unknowns associated with clumping of the R-F resin. It has happened several times during different types of operations with the earlier (BSC-187) batch of R-F resin. Sections 13.2.1.1 and 13.2.1.2 discuss this in greater detail. It should be noted that neither PNL nor Savannah River Westinghouse have had the clumping occur with the later (BSC-210) resin. The reason for this is unknown. However, during a meeting on August 4, 1994, Dr. Jane Bibler stated that it may be because the newer resin received a better water wash to remove fines and unreacted organics from the manufacturing process than previously manufactured batches of resin before it was shipped from the manufacturer.

NOTE: $\quad$ The concept of purchasing acid washed R-F resin in the H+form should be evaluated. Purchasing acid washed $R-F$ resin decreases the amount of fines remaining on the resin. Currently only a small portion of 1 batch of $R-F$ resin has been obtained in the acid washed $(\mathrm{H}+$ ) form. No data is currently available to show whether purchasing the R-F resin in the $\mathrm{H}+$ form increases or decreases the time the resin may be stored without noticeable degradation. 
13.2.1.1 Clumping of Resorcinol-Formaldehyde Resin During Radiation Testing. Radiation testing of the $B S C-187$ batch of R-F resin under simulated waste flow conditions was performed. During the testing, both the irradiated sample and the control exhibited clumping after approximately 1,400 hours of exposure to $(0.5 \mathrm{BV} / \mathrm{h})$ flow of NCAW simulant.

The resin in the facility columns will be exposed to approximately 1,200 to 1,400 hours of waste feed before changeout. This is close to the exposure at which the clumping occurred. In addition, the columns will also go through water washes, acid elution, and sodium hydroxide regeneration. The water washes and the sodium hydroxide regeneration may reduce the probability of the clumping, but that is still an unknown.

The clumping issue represents a significant potential problem. It may result in incomplete elution and problems removing the resin from the column. Further testing is needed to determine the cause and possible corrective actions. Also, testing should be performed to determine if clumping will occur with the newer form of the R-F resin (BSC-210).

13.2.1.2 Clumping of Resorcinol-Formaldehyde Resin During Elution. During several of the elution tests, the BSC -187 batch of the R-F resin clumped together during elution with either $\mathrm{HCOOH}$ or $\mathrm{HNO}_{3}$ (see the elution data table in Appendix A). The clumping caused channeling and resulted in poor elution characteristics. The clumping can be prevented or broken up by stirring or agitating the resin in the column during elution (Kurath et al. 1994). However, the cause of the clumping is unknown.

To date, clumping has not been seen with the BSC-210 batch of R-F resin. However, we do not know why the two batches of resin act differently. Future batches of R-F resin could have the same clumping problem as BSC-187.

Clumping needs to be studied to determine if the problem is unique to the one batch or whether handling and processing methods or other conditions are the cause. Unless the cause is certain, development of clumping and its prevention is unpredictable.

Methods of dealing with the clumping issue on a production scale must be developed prior to use of the R-F resin in full scale plant operations.

\subsubsection{Residual Cesium on the Ion Exchange Resin}

The current plans are for the $\mathrm{NaOH}$ regeneration solution to become part of the $L L W$ from the ion exchange process. Some cesium will remain on the ion exchange resin at the end of the acid elution step. Part of that residual cesium will be displaced from the resin by sodium while the resin is being regenerated. If a significant amount of cesium is displaced during the regeneration, the regeneration waste may have to be sent to the HLW stream. This could greatly increase the volume of HLW. An alternative which deserves future consideration is sending the used sodium hydroxide solution to a 1 ag storage tank, which will allow the solution to be reused at other locations in the overall pretreatment process. 
In addition, some of the residual cesium may be displaced when column loading is restarted after elution and regeneration. The portion of solution containing displaced cesium would be recycled, resulting in increased process throughput requirements.

Loading and elution cycle performance tests are planned. Part of the testing will be to determine the amount of residual cesium and if it will be a problem.

\subsubsection{Resin Degradation in a Caustic Environment}

During a meeting held on August 4, 1994, Dr. Jane Bibler stated that the resin degrades in the presence of caustic. Degradation may be seen after approximately 200 hours in the presence of caustic. Therefore, the resin should not be stored in an alkaline environment. It should be rinsed with water after regeneration and before storage.

The alkaline degradation has significant ramifications for using the resin with Hanford tank wastes. The Hanford wastes are high in caustic. Testing will need to be performed to determine the significance of the resin degradation in the presence of Hanford waste chemicals.

\subsection{CESIUM ION EXCHANGE FEED}

Feed characteristics significantly affect resin performance. Feed with a high viscosity will affect the kinetics of the reaction, requiring greater residence time in the ion exchange column to allow the cesium to be removed than with a less viscous solution. (Kurath et al. 1994) Dilution beyond that needed to prevent precipitation is not recommended because the amount of originally undiluted waste which can be processed per cycle decreases. (Kurath et al. 1994)

The density of the Cs-IX feed solution is also important. DSSF feed has a high specific gravity (spg) of 1.43. The resin almost floats in the feed. If the feed had a much greater spg, the only thing preventing floating and redistribution of the resin would be the downward flow of the IX feed. Floating and redistribution are undesirable during loading because they would cause some of the highly loaded resin particles to be moved near the column exit. This would cause the column to break through before it is fully loaded. Therefore, dense feed solutions should be diluted the amount necessary to prevent floating of the resin particles.

\subsubsection{Competing Trace Chemicals In Waste}

Testing performed by LANL (Marsh et. al. 1994) has shown that certain trace chemicals (less than $0.01 \mathrm{M}$ ) in the waste supernatant, such as iron, zinc, and zirconium, may affect the amount of cesium which may be removed from the waste between elutions. These trace chemicals are only slightly soluble under the current waste conditions. They are in equilibrium with larger 
amounts of the chemical located in the sludge. However, if changes to the waste during removal and sludge washing affect the solubility of those chemicals, the ability to remove cesium could be affected greatiy.

\subsubsection{Competing Chemicals from Group IA of the Periodic Table}

Sodium, potassium, and rubidium are in the same chemical group as cesium and will compete with cesium for the ion exchange sites. Therefore, the concentration of those chemicals, and the ratios of their concentrations to that of cesium will be important with respect to the performance of the ion exchange resin.

Sodium is the main competitor with respect to both concentration and concentration ratio. The cesium selectivity with respect to sodium increases with decreasing sodium concentration. However, at a constant $\mathrm{Na} / \mathrm{Cs}$ ratio, the amount of undiluted waste which can be processed will decrease at a faster rate than the dilution (Kurath et al. 1994). Therefore, it will not be beneficial to dilute the waste beyond the minimum needed to process the waste. At a constant sodium concentration, the cesium selectivity increases with increasing $\mathrm{Na} / \mathrm{Cs}$ ratio. The rate at which the selectivity increases depends upon the value of the ratio (Kurath et al. 1994). Therefore, the performance cannot be assumed, but must be tested.

Potassium is a competitor present in lower concentrations than sodium. However, it appears to affect the performance much more than sodium does. No tests have been performed to quantify how the concentrations of potassium, and ratios of $\mathrm{K} / \mathrm{Cs}$ affect the selectivity of the resin for cesium. This type of correlation is needed for providing a rough idea of how an individual waste may perform. However, it is not a substitute for column testing with actual waste.

Rubidium is a strong competitor for the ion exchange sites. However, rubidium is present in the tanks in very low concentrations $\left({ }^{\sim} 10^{-4} \mathrm{M}\right)$. No tests have been performed to quantify how the concentration of rubidium and the ratio of $\mathrm{Rb} / \mathrm{Cs}$ will affect the selectivity of the resin for cesium. However, the best guess, based upon B PIant experience, is that rubidium wi17 cause less than a 10\% decrease in the amount of waste which can be processed between elutions.

\subsubsection{Organics in the Ion Exchange Feed}

Organics are present in many of the tank wastes. The potential for fouling of the resin by organics remains an unresolved issue. The affect of organics present in the tank waste on the ion exchange system is unknown.

Testing to date has shown that fouling by organic chelating agents does not occur. Planned testing should determine whether fouling by other organics in the supernate occurs. 


\subsection{FILTRATION}

Suspended solids in the IX feed have the potential to plug the resin bed or foul the resin. The IX feed must be filtered to remove those solids before being fed to the IX columns. Currently, the filtration requirements with regard to the particle size which must be filtered, and the percentage which must be removed are not known. Testing needs to be performed to determine the filtration requirements.

\subsection{FOULING OF RESIN}

Fouling of the resin could occur during operation of the ion exchange process. This can be caused by many things such as organics, precipitation of aluminum containing compounds, build-up of non-removable cations on the ion exchange sites, etc. Fouling of the resin results in early column breakthrough and would probably require changeout of the resin to solve the symptom of the problem. If, during ion exchange operations, resin fouling is suspected, the problem will need to be investigated on an individual waste basis to determine how to prevent the fouling.

\subsection{SODIUM HYDROXIDE RINSE AT END OF EACH FEED CYCLE}

The need for having a $\mathrm{NaOH}$ rinse at the completion of each waste feed cycle is currently unknown. The $\mathrm{NaOH}$ rinse would flush out the interstitial waste, thereby preventing precipitation of aluminum compounds on the resin when the water rinse is performed. Testing to determine the need for the $\mathrm{NaOH}$ rinse should be performed. This would allow minimization or elimination of the chemicals sent to waste from the sodium hydroxide rinse.

\subsection{EVAPORATION ENERGY}

Large amounts of energy are required to remove the large quantities of water from the ion exchange feed, from the LLW stream, and from the concentrated cesium product stream. Approximately $7,187 \mathrm{~L} / \mathrm{h}$ will need to be evaporated from the NCAW feed stream per hour, and 3,600 L/h (when processing NCAW) will need to be removed from the stream to be made into low level glass. This will require approximately $7.30 \times 10^{3} \mathrm{Kw}\left(2.49 \times 10^{7} \mathrm{Btu} / \mathrm{h}\right)$ of energy.

\subsection{OPERATION OF 3 COLUMNS IN SERIES}

The operation of 4 ion exchange columns with 3 columns in series online at any time may be unacceptably difficult because problems will occur with valves, pumps, and many other pieces of mechanical equipment. The valve leaks may be hard to detect and it may be even harder to determine which valve is leaking. A leak may contaminate the solution which has been processed or the regeneration solution. If that occurs, the solution would have to be reprocessed. 
If fewer ion exchange columns in series are used, the length of the individual columns needed to achieve a certain DF would increase. The pressure drop in a long column would be extremely high. In addition, the amount of secondary waste generated in the form of sodium hydroxide regeneration solution, $\mathrm{HNO}_{3}$ eluant, and spent resin increases because the resin is not fully loaded each time it is eluted and regenerated. Parallel systems may be an attractive option. Resin bed size limits must be determined by column retention time requirements, pressure drop data, and safety concerns, e.g.,

${ }^{137} \mathrm{Cs}$ loading limits, emergency cooling and venting requirements.

\subsection{NUMBER OF ION EXCHANGE SYSTEM PASSES}

The high cesium removal efficiency required (greater than 99\%) for a single pass ion regenerable exchange process has not been demonstrated in the laboratory because of the large amount of radioactive cesium tracer which would be required. Future tests should demonstrate that it is possible to achieve the required DF in the laboratory.

However, even if the required efficiency can be achieved in the laboratory, it will be extremely difficult to maintain that type of DF during operation of a full scale single pass regenerable system. Therefore, a multiple pass system may be required. A multiple pass system normally contains additional tanks and two or more sets of ion exchange columns. Therefore, it costs more. A multiple pass system contains a collection tank on the outlet of the primary set of ion exchange columns to feed the secondary set of ion exchange columns (see section 5.2.1 for more definitions of single and multiple pass IX systems). The additional equipment increase the maintenance requirements. The additional set(s) of ion exchange columns increases the operating complexity. Therefore, a multiple pass system will not be used unless the product requirements cannot be met using any other method. 


\subsection{DEVELOPMENT}

There are still several areas which need further work to complete the development of the ion exchange process.

- Cyclic performance tests need to be completed. These tests will help to determine the effects of repeated loading and elution cycling on ion exchange system performance. The tests will help to determine the effects of incomplete cesium elution. The tests will also aid in determining whether the clumping problems encountered during earlier tests are a problem with the later versions of the $R-F$ resin. These tests are scheduled for FY 1995.

- Tests need to be performed to optimize the resin elution and regeneration. These are needed to minimize the secondary waste generated by the ion exchange process.

- The storage and disposal methods for the spent resin need to be resolved.

- Testing to determine the need for a $\mathrm{NaOH}$ rinse at the end of each waste feed cycle should be performed. This would minimize the chemicals sent to waste if the $\mathrm{NaOH}$ rinse in not actually needed.

- Ion exchange tests with actual waste need to be conducted to verify the applicability to simulant studies. The tests will also identify where there may be problems or interferences when processing actual wastes. These tests will provide a much better idea of how the resin will perform under actual conditions.

- Process safety data needs to be generated for the R-F resin. This includes data with respect to reaction of the resin with various concentrations of $\mathrm{HNO}_{3}$. The rate of reaction and the heat generation from the reaction are very important for correctly designing a system for safety.

- Tests should be performed to determine the filtration requirements for suspended solids in the IX feed.

- Completion of tests to determine whether organics in the waste wi11 cause resin fouling problems is required. Testing to date has shown that the organic chelating agents do not cause fouling. Testing of other organics, including separate phase organics, and radiologically degraded organics needs to be completed. These tests are scheduled for FY 1995 and 1996.

- Testing to determine how $R-F$ resin performance is affected by potassium concentration and by $K / C s$ ratio should be performed. This is needed to predict resin performance under varying feed compositions and conditions. 
- Loading and elution models currently being developed need to be completed improve prediction of resin performance with various feed compositions and conditions.

- Development of online, remote gamma monitors for the detection of ${ }^{137} \mathrm{Cs}$ at the concentrations ranges required by this process must be completed.

- Testing to determine the recommended materials of construction for the process equipment is needed. The testing is scheduled for FY-95.

- Testing should be done to determine the optimum $R-F$ resin particle size distribution for column loading.

- Further radiological resin degradation tests, which are scheduled for FY 1995 and 1996.

- Testing to determine the effect of ammonium ions on cesium ion exchange should be performed.

- Further engineering studies which consist of the following:

IPM trade studies. The trade studies examine issues related to the pretreatment of supernates.

A revision(s) of the cesium ion exchange flowsheet(s). The purpose is to provide more information for the conceptual design of the cesium removal process and to help define development needs. This work is more specifically focused on the cesium removal process than are the trade studies which provide an overall systems engineering approach. The revision work is scheduled for FY 1995.

Functions and requirements definition. This work includes overall TWRS flowsheet work, and specific work which identifies functions and requirements related to cesium removal. 
WHC-SD-WM-TI-638 REV 0

\subsection{REFERENCES}

Alumkal, 1994, Internal Memo, Tank Waste Remediation Technical Strategy, Apri1 11, 1994, Westinghouse Hanford Company.

Bailey, J. W. 1992, Engineering Study - Initial Pretreatment Module Project W-236-B, WHC-SD-W236B-ES-001, Rev. 0, 1992, Prepared for Westinghouse Hanford Company, by Kaiser Engineers Hanford Company, Richland, Washington.

Bibler, J. F., et al. 1990, Testing a New Cesium-Specific Ion Exchange Resin for Decontamination of A7kaline High Activity Waste, WRSC-RF-89-682, January, 1990, Westinghouse Savannah River, Aiken, South Carolina/Pacific Northwest Laboratory, Richland, Washington.

Bibler, N. E., An Investigation of the Radiolytic Stability of a ResorcinolFormaldehyde Ion Exchange Resin, WSRC-RP-94-148, January, 1994, Westinghouse Savannah River, Aiken, South Carolina.

Boomer, K. D., et a1. 1993, Tank Waste Technical Options Report, WHC-EP-0616, Rev. 0, March 1993, Westinghouse Hanford Company, Richland, Washington.

Bray, L. A., et a1. 1984, Experimental Data Developed to Support the Selection of a Treatment Process for the West Valley Alkaline Supernatant, PNL-496-9, January, 1984, Pacific Northwest Laboratory, Richland, Washington.

Bray, L. A., et a1. 1990, Cesium Recovery Using Savannah River Laboratory Resorcino7-Formaldehyde Ion Exchange Resin, PNL-7273/UNC-510, March, 1990, Pacific Northwest Laboratory, Richland, Washington.

Bray, L. A., et a1. 1992, Equilibrium Data for Cesium Ion Exchange of Hanford CC and NCAW Tank Waste, TWRSPP-92-020, Apri1, 1992, Pacific Northwest Laboratory, Richland, Washington.

Bray, L. A., et a1. 1993, Initial Evaluation of Two Organic Resins and Their Ion Exchange Column Performance for the Recovery of Cesium from Hanford Alkaline Tank Wastes, TWRSPP-93-055, 1993, Pacific Northwest Laboratory, Richland, Washington.

Code of Federal Regulations, 10 CRF, Ch.I (1-1-86 Edition), Part 61.55, Classification for Near Surface Disposal.

Eager, K. M. and D. L. Penwe11, 1994, Preliminary Flowsheet: Ion Exchange Process for the Separation of Cesium From Hanford Tank Waste using Duolite ${ }^{\mathrm{TM}}$ CS-100 Resin, WHC-SD-WM-TI-558, Rev. 0, September 1994, Westinghouse Hanford Company, Richland, Washington.

Ecology, et a1., 1989, Hanford Federal Facility Agreement and Consent Order, May 1989, Washington State Department of Ecology, U.S. Environmental Protection Agency, U.S. Department of Energy, Olympia, Washington. 
Ecology, et a1. 1994, Hanford Federal Facility Agreement and Consent Order, Fourth Amendment, January 1994, Washington State Department of Ecology, U.S. Environmental Protection Agency, U.S. Department of Energy, 01 ympia, Washington.

Ga17agher, S. A. 1986, Report of Current NCAW Ion Exchange Laboratory Data, Letter Report 65920-086, to M.W. Gibson, June 20, 1986, Rockwe11 Hanford Operations, Richland, Washington.

Gangwer, T. E., M. Goldstein, and K. K. S. Pillay, BNL 50781, Radiation Effects on Ion Exchange Materials, November, 1977, Brookhaven National Laboratory, Upton, New York.

Gibson, M. W. and B. C. Landeene 1987, Process Flowsheet, Demonstration of Neutralized Current Acid Waste Pretreatment at B Plant, PFD-B-033-00001, Rev. A-1, September 1997, Rockwell Hanford Operations, Richland, Washington.

Helfferich, F. G., et. al., Text from the AIChE Today Series, Ion Exchange Theory and Practice, American Institute of Chemical Engineers, 1992, New York, New York.

Klem, M. J., Chromatographic Ion Exchange Purification and Conversion of Americium to Oxide, ARH-F-110, April 25, 1977, Atlantic Richfield Hanford Company, Richland, Washington.

Kurath, D. E., et a1. 1994, Experimental Data and Analysis to Support the Design of an Ion Exchange Process for the Treatment of Hanford Tank Waste Supernatant Liquids, TWRSPP-94-010, January, 1994, Prepared for Westinghouse Hanford Company, by Pacific Northwest Laboratory, Richland, Washington.

Lukchis, George, M., 1973, "Adsorption Systems", Chemical Engineering, June 11,1973 .

Marsh, S. F. et. a1., 1994, Distributions of 14 Elements on 63 Absorbers From Three Solutions (Acid-Dissolved Sludge, Acidified Supernate, and A7kaline Supernate) for Hanford HLW Tank 102-SY, LA-12654, August 1994, Los A1amos National Laboratory, Los ATamos, New Mexico.

Miles, F. W., Ion Exchange Resin System Failures in Processing Actinides, Nuclear Safety, Volume 9, No. 5, September, 1968.

Orme, R. M. 1994, TWRS Process Flowsheet, WHC-SD-WM-TI-613, Rev. 0, 1994, Westinghouse Hanford Company, Richland, Washington.

Prignano, A. L., Letter to B. C. Landeene, Maximum Cesium Loading Capacity of Four Resins, 12712-PCL89-158, August 30, 1989, Westinghouse Hanford Company, Richland, Washington.

Swanson, L. M., et. al., 1994, Functions and Requirements for Project W236B, Initial Pretreatment Module, WHC-SD-W236B-FRD-002 Rev 1, September 1994, Westinghouse Hanford Company, Richland Washington. 
Winkler, C. M., 1993, Process Evaluation for In-Tank Washing of 101-AZ and 102-AZ STudges, WHC-SD-WM-PE-051, Rev. 0, September 1993, Westinghouse Hanford Company, Richland, Washington. 
WHC-SD-WM-TI-638 REV 0

This page intentionally left blank. 
WHC-SD-WM-TI-638 REV 0

APPENDIX A

\section{CALCULATIONS}

A-1 
WHC-SD-WM-TI-638 REV 0

This page intentionally left blank. 


\section{APPENDIX A}

\section{CALCULATIONS}

\section{A1.0 DESIGN BASIS/ASSUMPTIONS}

\section{A1.1 Radionuclide Removal Requirements}

The estimated degree of radionuclide removal that will be assumed for the purposes of this document is calculated as follows:

It wi11 be assumed that the final LLW glass form wi11 have a maximum activity from ${ }^{137} \mathrm{Cs}$ of $1.0 \mathrm{Ci}{ }^{137} \mathrm{Cs} / \mathrm{m}^{3}$, which is the $\mathrm{NRC}$ Class A limit for ${ }^{137} \mathrm{Cs}$. No other radionuclide besides Cesium is assumed to require removal.

The following are general assumptions about physical properties used to calculate the mass balance for this process:

- Assumptions for cesium

- about $86.6 \mathrm{Ci}{ }^{137} \mathrm{Cs} / \mathrm{g}{ }^{137} \mathrm{Cs}^{+}$

- The isotopic ratio for ${ }^{137} \mathrm{Cs}^{+}$in $\mathrm{NCAW}$ is $0.38 \mathrm{~g}^{137} \mathrm{Cs}^{+} / \mathrm{g} \mathrm{Cs}^{+}$

- The isotopic ratio for ${ }^{137} \mathrm{Cs}^{+}$in DSSF is $0.25 \mathrm{~g}^{137} \mathrm{Cs}^{+} / \mathrm{g} \mathrm{Cs}^{+}$

The following calculation sets the limit for the amount of cesium that can be in the LLW stream after cesium ion exchange as related to the sodium concentration:

$$
\begin{aligned}
& \frac{1.0 \mathrm{Ci} \mathrm{Cs}^{137}}{\mathrm{~m}^{3} \mathrm{glass}}\left|\frac{\mathrm{m}^{3} \mathrm{glass}}{2.6 \mathrm{MT} \mathrm{glass}}\right| \frac{\mathrm{MT} \mathrm{glass}}{0.2 \mathrm{MT} \mathrm{Na} \mathrm{N}_{2} \mathrm{O}}\left|\frac{\mathrm{MT}}{1,000 \mathrm{~kg}}\right| \frac{62 \mathrm{~kg} \mathrm{Na} \mathrm{Na}_{2} \mathrm{O}}{\mathrm{kg} \mathrm{me} \mathrm{Na}_{2} \mathrm{O}} \\
& \frac{\mathrm{kg} \mathrm{mole} \mathrm{Na}_{2} \mathrm{O}}{2 \mathrm{~kg} \mathrm{~mole} \mathrm{Na}^{+}}\left|\frac{\mathrm{kg} \mathrm{mole} \mathrm{Na}^{+}}{23 \mathrm{~kg} \mathrm{Na}}\right| \frac{1,000 \mathrm{~kg}}{\mathrm{MT} \mathrm{Na}^{+}}=2.59 \frac{\mathrm{Ci} \mathrm{Cs}}{\mathrm{MT} \mathrm{Na}^{+}}
\end{aligned}
$$

\section{A1.2 RESORCINOL-FORMALDEHYDE RESIN PERFORMANCE}

The mass balances for this flowsheet are based upon resin performance data from reference $A l$.

\section{A1.2.1 Comparison of Simulants to Estimated CS-IX Feed}

The Table A-1 compares the compositions of the waste simulants which were used to collect resin performance data in reference $A 1$ to the compositions of the Cs-IX feed streams estimated by this flowsheet. 
Table A-1. Comparison of NCAW and DSSF Simulants to Flowsheet Estimated Cs-IX Feeds.

\begin{tabular}{|l|c|c|c|c|}
\hline & $\underline{M} \mathrm{Na}^{*}$ & $\underline{\mathrm{M} \mathrm{Cs}}$ & $\underline{\mathrm{M} \mathrm{K}^{*}}$ & gmole Na /gmole Cs \\
\hline NCAW Simulant & 4.987 & $5.0 \mathrm{E}-04$ & 0.12 & $9.97 \mathrm{E}+03$ \\
\hline $\begin{array}{l}\text { Flowsheet Estimate, } \\
\text { NCAW CS-IX Feed }\end{array}$ & 5.0 & $4.21 \mathrm{E}-04$ & 0.11 & $1.19 \mathrm{E}+04$ \\
\hline DSSF Simulant & 7.0 & $7.0 \mathrm{E}-05$ & 0.945 & $1.00 \mathrm{E}+05$ \\
\hline $\begin{array}{l}\text { Flowsheet Estimate, } \\
\text { DSSF CS-IX Feed }\end{array}$ & 7.0 & $5.63 \mathrm{E}-04$ & 0.478 & $1.24 \mathrm{E}-04$ \\
\hline
\end{tabular}

Based on comparison with the estimated ion exchange feed compositions the following discrepancies are indicated:

- The DSSF simulant is lower in cesium than the estimated IX feed.

- The DSSF simulant is higher in potassium than the estimated IX feed.

\section{A1.2.2 Limits of Detection of Laboratory Data}

The cesium concentration data reported in reference $A 1$ are in a range low enough to allow estimation of a process mass balance capable of achieving the Class A limits for both the NCAW and the DSSF waste, however the reported detection limit for the reference $A 1$ data is above that required to meet a Class A 1 imit for the NCAW and about equivalent to that required for the DSSF waste. A lower detection limit is needed for further laboratory data, if a Class $A$ waste form is to be the processing goal.

Reference $A l$ presents cesium concentration data in units of $C / C_{0}$. Where $C$ is defined as the concentration of cesium in the waste stream after cesium ion exchange in gmole $\mathrm{Cs}^{+} / \mathrm{L}$ solution, and $\mathrm{C}_{0}$ is defined as the concentration of cesium in the waste stream before cesium ion exchange in gmole $\mathrm{Cs}^{+} / \mathrm{L}$ solution. The following calculations convert the ${ }^{137} \mathrm{Cs} C l$ ass $\mathrm{A}$ limit $\left(2.59 \mathrm{Ci}{ }^{137} \mathrm{Cs} / \mathrm{MT} \mathrm{Na}{ }^{+}\right.$in the $\mathrm{LLW}$ stream) to the $\mathrm{C} / \mathrm{C}_{0}$ format for comparison:

The 1 aboratory data was taken for a NCAW simulant with a $C_{0}$ of $5.0 \times 10^{-4}$ gmoles $\mathrm{C}^{+} / L$ of $5 \mathrm{M} \mathrm{Na} \mathrm{Na}^{+}$simulant solution. If the waste is to meet Class $A$ limits, the LLW stream would have to have a $C / C_{0}$ concentration of cesium of no more than the following: 


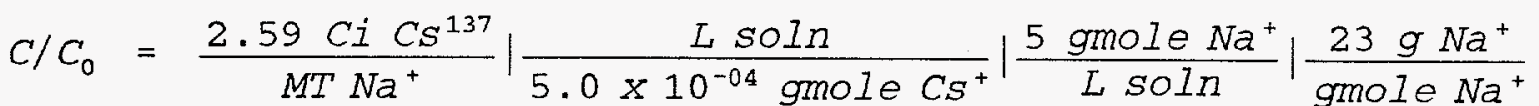

$$
\begin{aligned}
& \frac{\mathrm{kg}}{1,000 \mathrm{~g}}\left|\frac{\mathrm{MT} \mathrm{Na}}{1,000 \mathrm{~kg}}\right| \frac{g m o l e \mathrm{Cs}^{+}}{134 \mathrm{gCs}^{+}}\left|\frac{\mathrm{gCS}}{0.38 \mathrm{gCs}^{+}}\right| \frac{g \mathrm{Cs}^{137}}{86.6 \mathrm{Ci} \mathrm{CS}^{137}} \\
& =1.35 \times 10^{-04}
\end{aligned}
$$

The corresponding maximum cesium concentration in the LLW stream for the DSSF waste is $\mathrm{C} / \mathrm{C}_{0}$ of $2.0 \times 10^{-3}$.

Reference Al states that the cesium detection limit for the data is $2.0 \times 10^{-3} \mathrm{C} / \mathrm{C}_{0}$, although data is reported to $1.0 \times 10^{-4} \mathrm{C} / \mathrm{C}_{0}$.

\section{A1.2.3 R-F Resin Loading}

The cesium equilibrium distribution coefficient (Cs $\lambda$ ) is defined as follows:

$$
\begin{aligned}
& \lambda=\text { Cesium equilibrium distribution coeficient } \\
& \lambda=\frac{\left(\mathrm{gCs}{ }^{+} \text {on resin }\right)}{(\mathrm{mL} \text { resin })} \frac{(\mathrm{mL} \text { soln })}{\left(\mathrm{gCs}{ }^{+} \text {remaining in soln }\right)}
\end{aligned}
$$

A1.2.3.1 Theoretical Loading Performance With NCAW. For resorcinolformaldehyde resin, with NCAW simulant at $25{ }^{\circ} \mathrm{C}$, with a $5 \mathrm{M} \mathrm{Na}{ }^{+}$concentration and a sodium to cesium mole ratio of $10^{4}$ the lambda value was found to be approximately 182, with units as follows (ref. A1):

$$
\begin{aligned}
& \lambda=182 \frac{\left(\mathrm{g} \mathrm{Cs}^{+} \text {on resin }\right)}{(\mathrm{mL} \text { resin })} \frac{(\mathrm{mL} \text { soln })}{\left(\mathrm{gCs}^{+} \text {remaining in soln }\right)}
\end{aligned}
$$

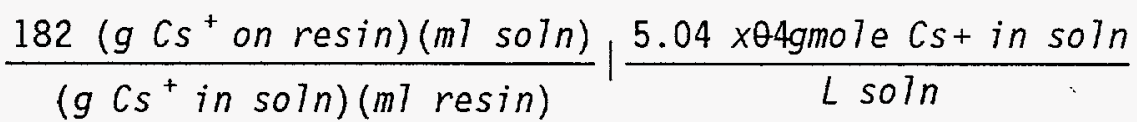

$$
\begin{aligned}
& \frac{L}{1,000 \mathrm{~mL} \mathrm{soln}}\left|\frac{134 \mathrm{gCs}^{+}}{\text {gmole Cs}{ }^{+}}\right| \frac{1,000 \mathrm{~mL}}{L \text { resin }} \mid \frac{1,000 \mathrm{mgCs}{ }^{+} \text {on resin }}{g} \\
& =12,194 \frac{m g \mathrm{Cs}^{+} \text {on resin }}{L \text { resin }}
\end{aligned}
$$




\section{A1.2.3.2 Theoretical Loading Performance With DSSF}

For resorcinol-formaldehyde resin, with DSSF-7 simulant at $25^{\circ} \mathrm{C}$, with a $7 \mathrm{M} \mathrm{Na}{ }^{+}$concentration and a sodium to cesium mole ratio of $10^{5}$ the 1 ambda value was found to be approximately 170:

$$
\begin{aligned}
& \frac{170\left(g \mathrm{Cs}^{+} \text {on resin }\right)(\mathrm{mL} \mathrm{soln})}{\left(g \mathrm{Cs}^{+} \text {in soln }\right)(\mathrm{mL} \text { resin })} \mid \frac{7.00 \times 10^{-5} \mathrm{gmole} C s+\text { in soln }}{L \text { soln }} \\
& \frac{L}{1,000 \mathrm{~mL} \mathrm{soln}}\left|\frac{134 \mathrm{~g} \mathrm{Cs}^{+}}{\text {gmole Cs}} \mathrm{Cs}^{+}\right| \frac{1,000 \mathrm{~mL}}{L \text { resin }} \mid \frac{1,000 \mathrm{mg} \mathrm{Cs}{ }^{+} \text {on resin }}{g} \\
& =1,594 \frac{\mathrm{mg} \mathrm{Cs}^{+} \text {on resin }}{L \text { resin }}
\end{aligned}
$$

A1.2.3.3 Estimated Actual Loading Performance. Tables A2-A7 were used to predict column performance of the $R-F$ resin in three onl ine ion exchange columns during cyclical operation with the NCAW and DSSF column feed. These tables are based on laboratory data from reference Al which used NCAW and DSSF simulants at $25^{\circ} \mathrm{C}$, with sodium concentrations of 5 and $7 M$ for the NCAW and DSSF solutions respectively.

The data taken for loading of DSSF Simulant on R-F resin at the desired flowrate were adjusted. The loading curves were generated using simulated waste with radioactive cesium tracer. The background radiation in the area of the counter was high during the DSSF loading tests. Therefore, the data showed immediate breakthrough, with the readings remaining about the same until the sample readings were above the background readings. From that point on, the loading breakthrough curves followed a typical breakthrough curve pattern.

It was assumed that the typical loading pattern would have been followed throughout the loading duration. The estimated breakthrough point and the data for the remaining points which were below the background radiation level were determined by extrapolation. The data is still skewed slightly (all values of $C / C_{0}$ are high). However, the data gave results that matched the batch contact data within experimental error, and the estimate should give a reasonable value for when the resin will need to be regenerated.

Note that the loading tables are based on laboratory data obtained from previously unused resin. For example Tables A-4 and A-7 show that the third column begins loading with zero cesium loaded. In a real system the third column would begin service with some amount of cesium as wel7 as other competing ions occupying ion exchange sites. For this reason the estimate of the number of bed volumes of ion exchange feed that can be processed between elution cycles derived from these tables may be optimistic. 
Table A-2. Column R Loading with Neutralized Current Acid Waste Simulant (Run 8).

\begin{tabular}{|c|c|c|c|c|c|c|}
\hline $\begin{array}{l}\text { Data } \\
\text { point }\end{array}$ & $\begin{array}{c}\text { BV } \\
(200 \mathrm{ml})\end{array}$ & $\begin{array}{c}\text { Time } \\
\text { (hours) }\end{array}$ & $\begin{array}{c}\text { Effluent } \\
C / C_{0}\end{array}$ & $\begin{array}{l}\text { Amount Cs loaded } \\
\text { on this segment } \\
\text { (mg Cs/L resin) }\end{array}$ & $\begin{array}{l}\text { Cs loading rate } \\
\text { (mg CS } / L \\
\text { resin/h) }\end{array}$ & $\begin{array}{l}\text { Cumulative amount Cs } \\
\text { loaded on column } \\
\text { (mg Cs/L resin) }\end{array}$ \\
\hline 0 & 0 & 0.0 & 0.0000 & 0.0 & 0.0 & 0.0 \\
\hline 1 & 9 & 1.0 & 0.0000 & 603.0 & 603.0 & 603.0 \\
\hline 5 & 94 & 5.4 & 0.0000 & 603.0 & 603.0 & 3283.0 \\
\hline 10 & 94 & 10.4 & 0.0000 & 603.0 & 603.0 & 6298.0 \\
\hline 11 & 103 & 11.4 & 0.0000 & 603.0 & 603.0 & 6901.0 \\
\hline 12 & 112 & 12.4 & 0.0018 & 602.5 & 602.5 & 7503.5 \\
\hline 14 & 130 & 14.4 & 0.0225 & 594.2 & 594.2 & 8698.1 \\
\hline 16 & 148 & 16.4 & 0.1042 & 555.1 & 555.1 & 9832.8 \\
\hline 18 & 165 & 18.3 & 0.2541 & 422.0 & 474.7 & 10774.8 \\
\hline 20 & 183 & 20.3 & 0.4478 & 360.7 & 360.7 & 11554.5 \\
\hline 22 & 200 & 22.2 & 0.6129 & 225.5 & 253.7 & 12083.5 \\
\hline 24 & 219 & 24.3 & 0.7823 & 152.2 & 152.2 & 12461.5 \\
\hline 26 & 238 & 26.4 & 0.8636 & 95.0 & 95.0 & 12689.2 \\
\hline 28 & 254 & 28.2 & 0.9053 & 54.1 & 60.9 & 12808.6 \\
\hline 30 & 272 & 30.2 & 0.9430 & 40.2 & 40.2 & 12900.4 \\
\hline 31 & 281 & 31.2 & 0.9584 & 29.7 & 29.7 & 12930.1 \\
\hline 32 & 290 & 32.2 & 0.9700 & 21.6 & 21.6 & 12951.7 \\
\hline 33 & 299 & 33.2 & 0.9722 & 17.4 & 17.4 & 12969.2 \\
\hline 34 & 307 & 34.1 & 0.9685 & 15.9 & 17.9 & 12985.1 \\
\hline 35 & 316 & 35.1 & 0.9960 & 10.7 & 10.7 & 12995.8 \\
\hline
\end{tabular}


Table A-3. Column S Loading with Neutralized Current Acid Waste Simulant (Run 8).

\begin{tabular}{|c|c|c|c|c|c|c|c|}
\hline $\begin{array}{l}\text { Data } \\
\text { Point }\end{array}$ & $\begin{array}{c}\text { BV } \\
(200 \mathrm{~mL})\end{array}$ & $\begin{array}{c}\text { Time } \\
\text { (hours) }\end{array}$ & Feed $\mathrm{c} / \mathrm{Co}$ & $\begin{array}{c}\text { Effluent } \\
\mathrm{C} / \mathrm{Co}\end{array}$ & $\begin{array}{l}\text { Amount of Cs } \\
\text { Loaded on segment } \\
\text { (mg Cs/L resin }\end{array}$ & $\begin{array}{l}\text { Cs Loading rate } \\
\text { (mg Cs } / \mathrm{L} \text { res in } \\
\text { per hour) }\end{array}$ & $\begin{array}{l}\text { Cumulative Cs } \\
\text { loaded on } \\
\text { column } \\
\text { (mg Cs/L } \\
\text { resin) }\end{array}$ \\
\hline 11 & 103 & 11.4 & 0.000 & 0.0000 & 0.0 & 0.0 & 0.0 \\
\hline 12 & 112 & 12.4 & 0.0018 & 0.0000 & 0.6 & 0.6 & 0.6 \\
\hline 15 & 139 & 15.4 & 0.0548 & 0.0000 & 23.3 & 23.3 & 35.2 \\
\hline 16 & 148 & 16.4 & 0.1042 & 0.0000 & 47.9 & 47.9 & 83.2 \\
\hline 17 & 157 & 17.4 & 0.1713 & 0.0000 & 83.1 & 83.1 & 166.2 \\
\hline 18 & 165 & 18.3 & 0.2541 & 0.0000 & 114.0 & 128.3 & 280.3 \\
\hline 19 & 174 & 19.3 & 0.3560 & 0.0000 & 183.9 & 183.9 & 464.2 \\
\hline 20 & 183 & 20.3 & 0.4478 & 0.0000 & 242.3 & 242.3 & 706.5 \\
\hline 25 & 229 & 25.4 & 0.8214 & 0.0000 & 537.2 & 483.5 & 2748.8 \\
\hline 30 & 272 & 30.2 & 0.9430 & 0.0000 & 562.8 & 562.8 & 5323.6 \\
\hline 33 & 299 & 33.2 & 0.9685 & 0.0000 & 584.5 & 584.5 & 7062.8 \\
\hline 34 & 307 & 34.1 & 0.9960 & 0.0018 & 526.0 & 591.8 & 7588.8 \\
\hline 35 & 316 & 35.1 & 0.9960 & 0.0035 & 599.0 & 599.0 & 8187.7 \\
\hline 36 & 325 & 36.1 & 0.9960 & 0.0152 & 594.9 & 594.9 & 8782.7 \\
\hline 37 & 333 & 37.0 & 0.9960 & 0.0362 & 520.1 & 585.1 & 9302.8 \\
\hline 38 & 342 & 38.0 & 0.9960 & 0.0744 & 567.2 & 567.2 & 9870.0 \\
\hline 39 & 351 & 39.0 & 0.9960 & 0.1325 & 538.2 & 538.2 & 10408.2 \\
\hline 40 & 360 & 40.0 & 0.9960 & 0.2021 & 499.7 & 499.7 & 10907.9 \\
\hline 41 & 369 & 41.0 & 0.9960 & 0.2881 & 452.8 & 452.8 & 11360.7 \\
\hline 42 & 378 & 42.0 & 0.9960 & 0.3775 & 399.9 & 399.9 & 11760.6 \\
\hline 43 & 387 & 43.0 & 0.9960 & 0.4619 & 347.5 & 347.5 & 12108.1 \\
\hline 44 & 396 & 44.0 & 0.9960 & 0.5533 & 294.5 & 294.5 & 12402.6 \\
\hline 45 & 405 & 45.0 & 0.9960 & 0.6366 & 241.8 & 241.8 & 12644.5 \\
\hline 46 & 414 & 46.0 & 0.9960 & 0.7033 & 196.6 & 196.6 & 12841.1 \\
\hline 47 & 423 & 47.0 & 0.9960 & 0.7638 & 158.3 & 158.3 & 12999.3 \\
\hline 48 & 431 & 47.9 & 0.9960 & 0.7594 & 125.6 & 141.3 & 13125.0 \\
\hline 49 & 437 & 48.6 & 0.9960 & 0.7931 & 88.3 & 132.5 & 13213.3 \\
\hline 50 & 444 & 49.3 & 0.9960 & 0.8269 & 87.2 & 112.2 & 13300.6 \\
\hline 51 & 452 & 50.2 & 0.9960 & 0.8670 & 79.9 & 89.9 & 13380.4 \\
\hline 52 & 461 & 51.2 & 0.9960 & 0.8920 & 70.2 & 70.2 & 13450.7 \\
\hline 53 & 470 & 52.2 & 0.9960 & 0.9058 & 58.6 & 58.6 & 13509.3 \\
\hline 54 & 480 & 53.3 & 0.9960 & 0.9483 & 46.2 & 41.6 & 13555.4 \\
\hline 55 & 490 & 54.4 & 0.9960 & 0.9844 & 19.9 & 17.9 & 13575.3 \\
\hline
\end{tabular}


Table A-4. Column T Loading with Neutralized Current Acid Waste Simulant (Run 8).

\begin{tabular}{|c|c|c|c|c|c|c|c|}
\hline $\begin{array}{l}\text { Data } \\
\text { Point }\end{array}$ & $\begin{array}{c}\text { BV } \\
(200 \mathrm{~mL})\end{array}$ & $\begin{array}{c}\text { Time } \\
\text { (hours) }\end{array}$ & $\begin{array}{l}\text { Feed } \\
\text { C/Co }\end{array}$ & $\begin{array}{c}\text { Effluent } \\
\mathrm{C} / \mathrm{Co}\end{array}$ & $\begin{array}{l}\text { Amount of Cs } \\
\text { loaded on this } \\
\text { segment } \\
\text { (mg Cs/L resin) }\end{array}$ & $\begin{array}{l}\text { Cs loading rate } \\
\text { (mg Cs } / \text { L resin } \\
\text { per hour) }\end{array}$ & $\begin{array}{l}\text { Cumulative Cs } \\
\text { loaded on column } \\
\text { (mg Cs/L resin) }\end{array}$ \\
\hline 33 & 299 & 33.2 & 0.0000 & 0.0000 & 0.0 & 0.0 & 0.0 \\
\hline 35 & 316 & 35.1 & 0.0035 & 0.0000 & 1.6 & 1.6 & 2.1 \\
\hline 40 & 360 & 40.0 & 0.2021 & 0.0000 & 100.9 & 100.9 & 218.1 \\
\hline 45 & 405 & 45.0 & 0.6366 & 0.0000 & 358.8 & 358.8 & 1484.5 \\
\hline 46 & 414 & 46.0 & 0.7033 & 0.0000 & 404.0 & 404.0 & 1888.5 \\
\hline 47 & 423 & 47.0 & 0.7638 & 0.0000 & 442.3 & 442.3 & 2330.8 \\
\hline 48 & 431 & 47.9 & 0.7594 & 0.0000 & 408.2 & 459.2 & 2739.0 \\
\hline 49 & 437 & 48.6 & 0.7931 & 0.0000 & 312.1 & 468.1 & 3051.1 \\
\hline 50 & 444 & 49.3 & 0.8269 & 0.0000 & 379.9 & 488.4 & 3431.0 \\
\hline 55 & 490 & 54.4 & 0.9844 & 0.0000 & 647.5 & 582.7 & 6225.9 \\
\hline 56 & 499 & 55.4 & 0.9844 & 0.0000 & 593.6 & 593.6 & 6819.5 \\
\hline 57 & 508 & 56.4 & 0.9844 & 0.0019 & 593.0 & 593.0 & 7412.5 \\
\hline 58 & 517 & 57.4 & 0.9844 & 0.0095 & 590.2 & 590.2 & 8002.7 \\
\hline 59 & 527 & 58.6 & 0.9844 & 0.0251 & 648.0 & 583.2 & 8650.6 \\
\hline 60 & 535 & 59.4 & 0.9844 & 0.0544 & 506.3 & 569.6 & 9156.9 \\
\hline 61 & 544 & 60.4 & 0.9844 & 0.0998 & 547.1 & 547.1 & 9704.0 \\
\hline 62 & 55 & 61.4 & 0.9844 & 0.1625 & 514.5 & 514.5 & 10218.6 \\
\hline 63 & 562 & 62.4 & 0.9844 & 0.2482 & 469.8 & 469.8 & 10688.3 \\
\hline 64 & 571 & 63.4 & 0.9844 & 0.343 & 415.3 & 415.3 & 11103.7 \\
\hline 65 & 580 & 64.4 & 0.9844 & 0.4286 & 361.0 & 361.0 & 11464.6 \\
\hline 66 & 589 & 65.4 & 0.9844 & 0.5326 & 303.8 & 303.8 & 11768.4 \\
\hline 67 & 598 & 66.4 & 0.9844 & 0.619 & 246.4 & 246.4 & 12014.8 \\
\hline 68 & 607 & 67.4 & 0.9844 & 0.6948 & 197.5 & 197.5 & 12212.3 \\
\hline 69 & 616 & 68.4 & 0.9844 & 0.7586 & 155.4 & 155.4 & 12367.7 \\
\hline 70 & 624 & 69.3 & 0.9844 & 0.8134 & 106.3 & 119.6 & 12474.0 \\
\hline 71 & 633 & 70.3 & 0.9844 & 0.8577 & 89.8 & 89.8 & 12563.8 \\
\hline 72 & 642 & 71.3 & 0.9844 & 0.8933 & 65.7 & 65.7 & 12629.4 \\
\hline 73 & 651 & 72.3 & 0.9844 & 0.9237 & 45.8 & 45.8 & 12675.2 \\
\hline 74 & 660 & 73.3 & 0.9844 & 0.9486 & 29.1 & 29.1 & 12704.3 \\
\hline
\end{tabular}


Table A-5. Column PP (Run 15) Loading (DSSF Simulant).

\begin{tabular}{|c|c|c|c|c|c|c|}
\hline $\begin{array}{l}\text { Data } \\
\text { Point }\end{array}$ & $\begin{array}{c}\text { BV } \\
(200 \mathrm{~mL})\end{array}$ & $\begin{array}{c}\text { Time } \\
\text { (hours) }\end{array}$ & $\begin{array}{c}\text { Effluent } \\
C / C_{0}\end{array}$ & $\begin{array}{l}\text { Amount Cs loaded } \\
\text { this segment } \\
\text { (mg Cs/L resin) }\end{array}$ & $\begin{array}{l}\text { loading rate } \\
\text { (mg } \mathrm{Cs} / \mathrm{L} \text { resin } \\
\text { per hour) }\end{array}$ & $\begin{array}{c}\text { cumul at ive amount } \\
\text { Cs l aaded } \\
\text { (mg Cs/L resin) }\end{array}$ \\
\hline 0 & 0 & 0.0 & 0.000 & 0.0 & 0.0 & 0.0 \\
\hline 4 & 12.5 & 4.0 & 0.0000 & 29.4 & 29.1 & 116.8 \\
\hline 6 & 18.2 & 5.9 & 0.0004 & 26.8 & 29.1 & 170.3 \\
\hline 10 & 29.9 & 9.6 & 0.0013 & 28.5 & 29.0 & 280.0 \\
\hline 12 & 36.3 & 11.7 & 0.0030 & 30.3 & 29.0 & 340.0 \\
\hline 14 & 42.8 & 13.8 & 0.0051 & 30.4 & 29.0 & 401.1 \\
\hline 16 & 49.3 & 15.9 & 0.0077 & 30.2 & 28.9 & 461.2 \\
\hline 18 & 55.4 & 17.9 & 0.0107 & 28.1 & 28.8 & 518.0 \\
\hline 20 & 61.6 & 19.9 & 0.0160 & 28.2 & 28.7 & 575.2 \\
\hline 22 & 67.8 & 21.9 & 0.0405 & 28.5 & 28.2 & 632.0 \\
\hline 24 & 73.9 & 23.8 & 0.0518 & 27.2 & 27.7 & 687.3 \\
\hline 26 & 80.2 & 25.9 & 0.0602 & 27.9 & 27.4 & 743.0 \\
\hline 27 & 83.4 & 26.9 & 0.0679 & 27.8 & 27.2 & 770.8 \\
\hline 28 & 86.5 & 27.9 & 0.0770 & 27.4 & 27.0 & 798.3 \\
\hline 30 & 92.8 & 29.9 & 0.0923 & 26.2 & 26.5 & 851.9 \\
\hline 35 & 107.7 & 34.7 & 0.1441 & 24.1 & 25.1 & 975.1 \\
\hline 40 & 125.6 & 40.5 & 0.2610 & 29.4 & 21.9 & 1110.0 \\
\hline 45 & 142.8 & 46.1 & 0.3291 & 17.5 & 19.7 & 1222.0 \\
\hline 50 & 158.0 & 51.0 & 0.4308 & 16.6 & 16.9 & 1310.4 \\
\hline 55 & 173.2 & 55.9 & 0.5114 & 13.2 & 14.5 & 1385.7 \\
\hline 60 & 187.2 & 60.4 & 0.5809 & 11.8 & 12.4 & 1445.4 \\
\hline 65 & 201.4 & 65.0 & 0.6643 & 9.1 & 10.0 & 1495.6 \\
\hline 70 & 216.1 & 69.7 & 0.7848 & 6.3 & 6.3 & 1536.2 \\
\hline 75 & 231.2 & 74.6 & 0.8649 & 3.9 & 3.9 & 1560.9 \\
\hline 76 & 234.3 & 75.6 & 0.8935 & 3.5 & 3.5 & 1564.4 \\
\hline 80 & 246.9 & 79.6 & 0.9095 & 2.8 & 2.8 & 1577.0 \\
\hline 85 & 262.0 & 84.5 & 0.9033 & 2.5 & 2.5 & 1590.5 \\
\hline 90 & 277.6 & 89.5 & 0.9568 & 1.4 & 1.9 & 1601.1 \\
\hline 96 & 303.0 & 97.8 & 0.9889 & 1.0 & 0.5 & 1607.2 \\
\hline
\end{tabular}


Table A-6. Column QQ (Run 15) Loading (DSSF Simulant).

\begin{tabular}{|c|c|c|c|c|c|c|c|}
\hline $\begin{array}{c}\text { Data } \\
\text { point } \\
\text {. }\end{array}$ & $\begin{array}{c}\mathrm{BV} \\
(200 \mathrm{~mL})\end{array}$ & $\begin{array}{c}\text { Time } \\
\text { (hours) }\end{array}$ & $\begin{array}{l}\text { Feed } \\
\text { C/Co }\end{array}$ & $\begin{array}{c}\text { Effluent } \\
\text { C/Co }\end{array}$ & $\begin{array}{l}\text { Amount Cs loaded } \\
\text { th is segment } \\
\text { (mg Cs } / L \text { resin) }\end{array}$ & $\begin{array}{l}\text { Loading rate } \\
\text { (mg Cs/L } \\
\text { resin per } \\
\text { hour) }\end{array}$ & $\begin{array}{l}\text { Cumulative Cs } \\
\text { loaded on column } \\
\text { (mg Cs/L resin) }\end{array}$ \\
\hline 0 & 0 & 0.0 & 0.000 & 0.000 & 0.0 & 0.0 & 0.0 \\
\hline 26 & 80.2 & 25.9 & 0.0602 & 0.0001 & 22.7 & 0.9 & 22.7 \\
\hline 28 & 86.5 & 27.9 & 0.0770 & 0.0002 & 4.1 & 2.0 & 26.7 \\
\hline 30 & 92.8 & 29.9 & 0.0923 & 0.0002 & 2.5 & 2.6 & 31.7 \\
\hline 32 & 98.7 & 31.8 & 0.1101 & 0.0002 & 2.9 & 3.1 & 37.2 \\
\hline 35 & 107.7 & 34.7 & 0.1441 & 0.0003 & 3.8 & 4.0 & 47.9 \\
\hline 40 & 125.6 & 40.5 & 0.2610 & 0.0007 & 9.7 & 7.2 & 81.3 \\
\hline 45 & 142.8 & 46.1 & 0.3291 & 0.0015 & 8.3 & 9.3 & 130.2 \\
\hline 50 & 158.0 & 51.0 & 0.4308 & 0.0025 & 11.9 & 12.1 & 184.2 \\
\hline 55 & 173.2 & 55.9 & 0.5114 & 0.0043 & 13.2 & 14.5 & 251.3 \\
\hline 56 & 176.1 & 56.8 & 0.5300 & 0.0048 & 13.7 & 15.0 & 265.0 \\
\hline 60 & 187.2 & 60.4 & 0.5809 & 0.0078 & 15.6 & 16.4 & 322.1 \\
\hline 65 & 201.4 & 65.0 & 0.6643 & 0.0150 & 16.9 & 18.6 & 403.0 \\
\hline 70 & 216.1 & 69.7 & 0.7848 & 0.0260 & 21.9 & 22.0 & 498.6 \\
\hline 75 & 231.2 & 74.6 & 0.8649 & 0.0449 & 24.3 & 24.0 & 610.3 \\
\hline 76 & 234.3 & 75.6 & 0.8935 & 0.0496 & 24.1 & 24.2 & 634.3 \\
\hline 80 & 246.9 & 79.6 & 0.9095 & 0.0723 & 24.3 & 24.2 & 733.0 \\
\hline 85 & 262.0 & 84.5 & 0.9033 & 0.1049 & 24.2 & 23.6 & 848.3 \\
\hline 90 & 277.6 & 89.5 & 0.9568 & 0.1656 & 16.8 & 22.6 & 964.8 \\
\hline 95 & 299.8 & 96.7 & 0.9889 & 0.2719 & 21.6 & 20.9 & 1121.4 \\
\hline 100 & 322.0 & 103.9 & 1.0000 & 0.3758 & 35.9 & 18.4 & 1260.2 \\
\hline 105 & 353.7 & 114.1 & 1.0000 & 0.5478 & 25.7 & 13.4 & 1418.4 \\
\hline 110 & 382.5 & 123.4 & 1.0000 & 0.6971 & 16.9 & 9.1 & 1521.2 \\
\hline 115 & 412.0 & 132.9 & 1.0000 & 0.8169 & 10.9 & 5.7 & 1589.1 \\
\hline 120 & 442.1 & 142.6 & 1.0000 & 0.8651 & 7.3 & 3.9 & 1634.6 \\
\hline 126 & 472.3 & 152.4 & 1.0000 & 1.0000 & 0.0 & 0.0 & 1638.4 \\
\hline 127 & 478.9 & 154.5 & 1.0000 & 1.0000 & 0.0 & 0.0 & 1638.4 \\
\hline
\end{tabular}


Table A-7. Column RR (Run 15) Loading (DSSF Simulant).

\begin{tabular}{|c|c|c|c|c|c|c|c|}
\hline $\begin{array}{l}\text { Data } \\
\text { Point }\end{array}$ & $\begin{array}{c}\mathrm{BV} \\
(200 \mathrm{~mL})\end{array}$ & $\begin{array}{c}\text { Time } \\
\text { (hours) }\end{array}$ & $\begin{array}{l}\text { Feed } \\
\text { C/Co }\end{array}$ & $\begin{array}{c}\text { Effluent } \\
\mathrm{C} / \mathrm{Co}\end{array}$ & $\begin{array}{l}\text { Amount Cs loaded } \\
\text { this segment } \\
\text { (mg Cs/L resin) }\end{array}$ & $\begin{array}{l}\text { Loading rate } \\
\text { (mg CS/L } \\
\text { resin per } \\
\text { hour) }\end{array}$ & $\begin{array}{c}\text { cumulative amount } \\
\text { Cs } \\
\text { loaded (mg Cs/L } \\
\text { resin) }\end{array}$ \\
\hline 26 & 80.2 & 25.9 & 0 & 0 & 0.0 & 0.0 & 0.0 \\
\hline 56 & 176.1 & 56.8 & 0.0205 & 0.0000 & 9.2 & 0.2 & 9.2 \\
\hline 76 & 234.3 & 75.6 & 0.0496 & 0.0001 & 19.1 & 0.4 & 28.3 \\
\hline 81 & 249.8 & 80.6 & 0.0770 & 0.0002 & 9.2 & 1.8 & 37.5 \\
\hline 85 & 262.0 & 84.5 & 0.1049 & 0.0003 & 10.3 & 2.6 & 47.8 \\
\hline 90 & 277.6 & 89.5 & 0.1656 & 0.0005 & 19.8 & 3.9 & 67.6 \\
\hline 95 & 299.8 & 96.7 & 0.2719 & 0.0012 & 7.9 & 7.7 & 113.8 \\
\hline 100 & 322.0 & 103.9 & 0.3758 & 0.0023 & 20.7 & 10.6 & 182.1 \\
\hline 104 & 347.8 & 112.2 & 0.5282 & 0.0060 & 59.0 & 14.1 & 290.3 \\
\hline 106 & 359.5 & 116.0 & 0.5821 & 0.0085 & 60.4 & 15.9 & 350.7 \\
\hline 110 & 382.5 & 123.4 & 0.6971 & 0.0180 & 36.0 & 19.4 & 483.5 \\
\hline 115 & 412.0 & 132.9 & 0.8169 & 0.0511 & 41.8 & 22.0 & 683.7 \\
\hline 120 & 442.1 & 142.6 & 0.8651 & 0.2000 & 39.0 & 20.7 & 894.1 \\
\hline 125 & 465.9 & 150.3 & 1.0000 & 0.3300 & 1.1 & 20.2 & 1061.7 \\
\hline 130 & 498.1 & 160.7 & 1.0000 & 0.5277 & 29.0 & 14.6 & 1236.3 \\
\hline 135 & 528.4 & 170.4 & 1.0000 & 0.7767 & 13.9 & 7.3 & 1335.7 \\
\hline 140 & 557.1 & 179.7 & 1.0000 & 0.9202 & 4.8 & 2.6 & 1377.6 \\
\hline 145 & 586.9 & 189.3 & 1.0000 & 1.0000 & 0.0 & 0.0 & 1387.1 \\
\hline 148 & 592.8 & 191.2 & 1.0000 & 1.0000 & 0.0 & 0.0 & 1387.1 \\
\hline
\end{tabular}

The tables show that the volume of ion exchange feed that can be processed through the ion exchange columns while still meeting LLW class A waste requirements is about 200 bed volumes for NCAW and about 144 bed volumes for DSSF. To account for a predicted decrease in resin performance due to differences between the actual process conditions and the conditions in which the laboratory data was obtained, the material balance of this flowsheet assumes an average of 180 bed volumes of ion exchange feed are processed through the columns between elutions for the NCAW, and an average of 129 bed volumes of ion exchange feed are processed through the columns between elutions for the DSSF waste. The major factors expected to decrease the performance of the resin in the actual process over that predicted by the Taboratory data are;

- Residual cesium or other competing ions potentially remaining on resin after elution

- Degradation of resin due to radiation

- Degradation of resin due to chemical cycling 
- Components in actual waste which compete for ion exchange sites, or foul resin, e.g., organics, suspended solids, precipitates, competing cations

- Scale-up factors such as, channelling, and valve leakage

Further testing is needed to determine the effects of these factors on resin loading performance.

\section{A1.2.4 Resin Elution}

The volume and mass of chemicals required to elute the loaded $R-F$ resin for this mass balance are estimated from data in reference $\mathrm{Al}$.

The elution data from reference $A 1$ has extremely wide scatter. Therefore, the data does not allow an definitive estimate of how much of the loaded cesium will be removed by acid elution, or more importantly, what percentage will remain. However, data from reference A-3 indicates that over $99 \%$ of the cesium can be removed using less than $10 \mathrm{BV}$ of $1 \mathrm{M} \mathrm{HCOOH}$.

Significant problems were encountered during the elution of the R-F resin. One of the problems encountered was the BSC-187 version of the R-F resin stuck together during elution, which caused channelling. The newer type of $R-F$ resin (BSC-210) does not appear to have that problem. However, there are still significant uncertainties regarding the elution of the R-F resin.

For the purposes of this flowsheet mass balance, greater than $99 \%$ of the initial mass of loaded cesium was is assumed to be removed from the resin each elution with 10.0 gmole $\mathrm{H}^{+} / \mathrm{L} \mathrm{R}-\mathrm{F}$ resin. This amounts to $40,000 \mathrm{~L}$ of $0.5 \mathrm{M} \mathrm{HNO}_{3}$ per elution. This is assumed to be true for the $R-F$ resin regardless of which solution (NCAW or DSSF) was used for loading. At 13 elutions required to process all of the NCAW, the total volume of eluant is $5.20 \times 10^{5} \mathrm{~L}$ of $0.5 \mathrm{M}$ $\mathrm{HNO}_{3}$. At 272 elutions required to process 211 of the DSSF, the total volume of eluant is $1.09 \times 10^{7} \mathrm{~L}$ of $0.5 \mathrm{M} \mathrm{HNO}_{3}$. A summary of column loading and elution data for $R-F$ resin derived from reference $A 1$ is shown in Table $A-8$. 
Table A-8. Summary of Column Loading and Elution Data for Resorcinol-Formaldehyde Resin.

\begin{tabular}{|c|c|c|c|c|c|c|}
\hline Column (test) & $R(8)$ & $V(8)$ & $x(8)$ & $Q Q^{3}(15)$ & (16) & $Y(10)$ \\
\hline $\begin{array}{l}\text { Resorcinol-formaldehyde } \\
\text { resin type }\end{array}$ & BSC- 187 & $B S C-187$ & BSC -187 & $B S C-187$ & $B S C-210$ & $B S C-210$ \\
\hline Loading simulant & NCAW & NCAW & NCAW & DSSF -7 & DSSF -7 & NCAW \\
\hline $\begin{array}{l}\text { Loading flow rate } \\
(200 \mathrm{~mL} \mathrm{BVs} / \mathrm{h})\end{array}$ & 9 & $\cdots$ & -- & 3 & 13.5 & -- \\
\hline Loading temperature $\left({ }^{\circ} \mathrm{C}\right)$ & 25 & 25 & 25 & 25 & 25 & 25 \\
\hline $\begin{array}{l}\text { Estimated maximum loading } \\
\left(\mathrm{mg} C \mathrm{~s}^{*} / L \text { resin) }\right.\end{array}$ & 12996 & -- & $\cdots$ & 1638 & 1160 & -- \\
\hline $\begin{array}{l}\text { Number BVs ( } 200 \mathrm{~mL} / \mathrm{BV}) \\
\text { simulant at maximum loading }\end{array}$ & 316 & $N A^{b}$ & $\cdots$ & $N A^{D}$ & 170 & -- \\
\hline $\begin{array}{l}\text { Cesium concentration in } \\
\text { loading column effluent at } \\
\text { maximum loading - }\left(C / C_{0}\right)\end{array}$ & 0.996 & $\cdots$ & -- & 1.09 & 0.7236 & $\cdots$ \\
\hline $\begin{array}{l}\text { Elution flowrate } \\
(200 \mathrm{~mL} \mathrm{Cvs/h)}\end{array}$ & 2 & 1 & 1 & $\begin{array}{l}\text { (stirred } \\
\text { column) } \\
1\end{array}$ & 1 & 1 \\
\hline Elution temperature $\left({ }^{\circ} \mathrm{C}\right)$ & 25 & 25 & 25 & 40 & 40 & 40 \\
\hline Eluant & $0.1 \underline{\mathrm{M}} \mathrm{HNO}_{3}$ & $1.0 \mathrm{M} \mathrm{HCOOH}$ & $0.4 \mathrm{M} \mathrm{HNO}_{3}$ & $0.4 \mathrm{M} \mathrm{HNO}$ & $1 \mathrm{M} \mathrm{HCOOH}$ & $\begin{array}{l}1 . \mathrm{OM} \\
\mathrm{HCOOH}\end{array}$ \\
\hline $\begin{array}{l}\text { Final mass of } \mathrm{Cs}^{\prime} \text { eluted } \\
\text { (mg } \mathrm{Cs}^{*} / \mathrm{L} \text { resin) }\end{array}$ & 5850 & -- & -- & 1318 & 1075 & 7244 \\
\hline $\begin{array}{l}\text { Total volume of eluant used - } \\
\text { - (200 mL BVs) }\end{array}$ & 26 & 37 & 37 & 11 & 13 & 11.5 \\
\hline $\begin{array}{l}\text { Final cesium conc in eluting } \\
\text { column effluent }--\left(C / C_{0}\right)\end{array}$ & 2 & 0.09 & 0.09 & 0.08 & 0.0001 & 0.007 \\
\hline$\%$ of Loaded cesium eluted & 45 & -- & -- & 80 & 93 & $\cdots$ \\
\hline $\begin{array}{l}\text { gmoles } H^{-} \text {required for elution } \\
\text { per liter resin }\end{array}$ & 2.6 & 37 & 14.8 & 4.4 & 13 & 11.5 \\
\hline
\end{tabular}

${ }^{a}$ Data is biased because radioactive solution was in the vicinity of the activity counter when loading data was taken.

bot lead column, so feed $\mathrm{C} / \mathrm{Co}$ fluctuated. 


\section{A2.0 MASS BALANCE}

\section{A2.1 NITRIC ACID INFORMATION}

$0.5 \mathrm{M} \mathrm{HNO}_{3}$ solution is about $3.1 \%$ (wt) in $\mathrm{HNO}_{3}$ with a density of about $1.01372 \mathrm{~g} / \mathrm{mL}$ at $25{ }^{\circ} \mathrm{C}$ (reference $\mathrm{A} 2$ ).

\section{A2.2 SODIUM HYDROXIDE INFORMATION}

$0.5 \mathrm{M} \mathrm{NaOH}$ solution is about $2.0 \%$ (wt) in $\mathrm{NaOH}$ with a density of about $1.0190 \mathrm{~g} / \mathrm{mL}$ at $25{ }^{\circ} \mathrm{C}$ (reference $\mathrm{A2}$ ). 2.0M NaOH solution is about $7.6 \%$ (wt) in $\mathrm{NaOH}$ with a density of about $1.0511 \mathrm{~g} / \overline{\mathrm{mL}}$ at $25{ }^{\circ} \mathrm{C}$ (reference $\mathrm{A2}$ ).

\section{A2.3 ION EXCHANGE CALCULATIONS FOR NCAW AND DSSF}

At the start of the loading phase the resin will be in the $\mathrm{Na}^{+}$form. During loading, $\mathrm{K}^{+}$and $\mathrm{CS}^{+}$will be adsorbed on the resin replacing $\mathrm{Na}^{+}$. During the elution step, hydronium ion $\left(\mathrm{H}^{+}\right)$will replace nearly all the $\mathrm{Na}^{+}$, $\mathrm{K}^{+}$, and $\mathrm{Cs}^{+}$. The replaced $\mathrm{Na}^{+}, \mathrm{K}^{+}$, and $\mathrm{Cs}^{+}$will go to $\mathrm{HLW} \mathrm{via}$ streams 540 , and 570. The number of cation sites on the resin can be estimated based on data from reference $\mathrm{Al}$. The resin capacity was estimated to be $1.57 \mathrm{eq} / \mathrm{L}$, assuming that cations will exchange with anions to the full capacity of the resin each elution.

Estimated Amount of Sodium and Hydronium Ion that will Load on the Resin--The ion exchange resin changes back and forth between the hydrogen and sodium forms several times during the life of the resin. During the regeneration step, sodium will be adsorbed on the resin releasing hydronium ions into the regeneration waste, Stream number 445 . To estimate the amount of sodium ion and hydronium $\left(\mathrm{H}^{+}\right)$ion that will exchange with the resin, an ion exchange capacity of $1.57 \mathrm{eq} / \mathrm{L}$ was used. (This is based upon data from reference Al.) It was assumed that hydronium is taken up to the full capacity of the resin and then given off into the regeneration waste stream. The hydronium ion will combine with the hydroxide in the regeneration waste to form water per reaction

$$
\begin{aligned}
& \mathrm{H}^{+}+\mathrm{OH}^{-} \rightarrow \mathrm{H}_{2} \mathrm{O} \text { in quantity as follows: } \\
& \frac{1.57 \mathrm{eq}}{\mathrm{L} \text { resin }}\left|\frac{\mathrm{lgmole} \mathrm{H}^{+}}{\mathrm{eq}}\right| \frac{2,000 \mathrm{~L}}{\operatorname{column}}\left|\frac{13 \text { columns }}{\text { NCAW }}\right| \frac{\text { kgmole }}{1,000 \text { gmole }} \\
& \frac{\text { kgmole } \mathrm{H}_{2} \mathrm{O}}{\text { kgmole } \mathrm{H}^{+}} \mid \frac{18 \mathrm{~kg} \mathrm{H} \mathrm{H}_{2} \mathrm{O}}{\mathrm{kgmole} \mathrm{H}_{2} \mathrm{O}}=7.35 \times 10^{2} \frac{\mathrm{kg} \mathrm{H} \mathrm{H}_{2} \mathrm{O}}{\mathrm{NCAW}}
\end{aligned}
$$




$$
\begin{gathered}
\frac{1.57 \mathrm{eq}}{\mathrm{L} \text { resin }}\left|\frac{1 \mathrm{gmole} \mathrm{H}^{+}}{\mathrm{eq}}\right| \frac{2,000 \mathrm{~L}}{\text { column }}\left|\frac{272 \text { columns }}{\text { DSSF }}\right| \frac{\text { kgmole }}{1,000 \text { gmole }} \\
\frac{\text { kgmole } \mathrm{H}_{2} \mathrm{O}}{\text { kgmole } \mathrm{H}^{+}} \mid \frac{18 \mathrm{~kg} \mathrm{H} \mathrm{H}_{2} \mathrm{O}}{\mathrm{kgmole} \mathrm{H}_{2} \mathrm{O}}=1.54 \times 10^{4} \frac{\mathrm{kg} \mathrm{\textrm {H } _ { 2 } \mathrm { O }}}{\text { DSSF }}
\end{gathered}
$$

The total amount of water in Stream number 441 would then be the initial amount of water plus this additional water or:

For NCAW:

$$
1.04 \times 10^{5} \mathrm{kgs} \mathrm{H}_{2} \mathrm{O}+7.35 \times 10^{2} \mathrm{kgs} \mathrm{H}_{2} \mathrm{O}=1.05 \times 10^{5} \mathrm{kgs} \mathrm{H}_{2} \mathrm{O}
$$

For DSSF

$$
2.17 \times 10^{6} \mathrm{kgs} \mathrm{H}_{2} \mathrm{O}+1.54 \times 10^{4} \mathrm{kgs} \mathrm{H}_{2} \mathrm{O}=2.19 \times 10^{6} \mathrm{kgs} \mathrm{H}_{2} \mathrm{O}
$$

The remaining amount of $\mathrm{OH}^{-}$ion would be the initial amount minus that which reacted with the hydronium ion. The initial amount of hydroxide was;

For NCAW:

$$
\frac{8.84 \times 10^{2} \mathrm{~g} \mathrm{OH}^{-}}{\mathrm{NCAW}} \mid \frac{\mathrm{kgmole} \mathrm{OH}^{-}}{17 \mathrm{~kg} \mathrm{OH}^{-}}=52 \frac{\mathrm{kgmole} \mathrm{OH}^{-}}{\mathrm{NCAW}}
$$

For DSSF:

$$
\frac{1.85 \times 10^{5} \mathrm{~kg} \mathrm{OH}}{D S S F} \mid \frac{\mathrm{kgmole} \mathrm{OH}^{-}}{17 \mathrm{~kg} \mathrm{OH}}=1,088 \frac{\mathrm{kgmole} \mathrm{OH}^{-}}{D S S F}
$$

The mass of hydroxide that would remain in Stream number 441 would be; For NCAW:

$$
\frac{\left(5.2 \times 10^{1}-4.08 \times 10^{1}\right){\mathrm{kgmole} \mathrm{OH}^{-}}^{-}}{\text {NCAW }} \frac{17 \mathrm{~kg} \mathrm{OH}^{-}}{\mathrm{kgmole}}=\frac{1.90 \times 10^{2} \mathrm{~kg} \mathrm{OH}^{-}}{\text {NCAW }}
$$


For DSSF:

$$
\frac{\left(1.088 \times 10^{3}-8.54 \times 10^{2}\right){\mathrm{kgmole} \mathrm{OH}^{-}}^{-}}{\text {DSSF }} \mid \frac{17 \mathrm{~kg} \mathrm{OH}}{\mathrm{kgmole}}=\frac{3.98 \times 10^{3} \mathrm{~kg} \mathrm{OH}^{-}}{D S S F}
$$

Hydronium ions will be adsorbed onto the resin from $\mathrm{HNO}_{3}$ elution solution in exchange for sodium ions which will form sodium nitrate in the eluate. The amount of sodium ion added to the eluate (Stream number 540 ) is calculated as follows; assuming that sodium will be adsorbed to the full capacity of the resin minus the amount of cesium adsorbed. Assuming that no other ions are present, the resin has the capacity to adsorb 3,140 eq of $\mathrm{Na}^{+}$per column per cycle.

\section{For NCAW:}

The amount of cesium adsorbed is estimated as $13,000 \mathrm{mg} \mathrm{Cs} / \mathrm{L}$ resin per cycle, based upon Tables A-2 through A-4.

$$
\begin{gathered}
\frac{13,000 \mathrm{mgCs}+}{L \text { resin }}\left|\frac{2,000 \mathrm{Lresin}}{\text { column }}\right| \frac{g \mathrm{Cs}^{+}}{1,000 \mathrm{mg}}\left|\frac{\mathrm{gmole} \mathrm{Cs^{+ }}}{134 \mathrm{gCs}^{+}}\right| \frac{\mathrm{eq}}{1 \mathrm{gmole} \mathrm{Cs}^{+}} \\
=194 \frac{\mathrm{eq}}{\mathrm{column}}
\end{gathered}
$$

Based on extrapolation of data in reference $A 1$, the potassium lambda was assumed to be 1 . That value was used to obtain the amount of potassium which would load onto the resin.

$$
\begin{aligned}
& \frac{1\left(g K^{+} \text {on resin }\right)(m L \text { soln })}{\left(g K^{+} \text {in soln }\right)(m L \text { resin })} \mid \frac{1.06 \times 10^{-1} \text { gmole } C s+\text { in soln }}{L \text { soln }} \\
& \frac{L}{1,000 \mathrm{~mL} \mathrm{soln}}\left|\frac{39 \mathrm{gK} K^{+}}{\text {gmole } K^{+}}\right| \frac{1,000 \mathrm{~mL}}{L \text { resin }}=4.13 \frac{g K^{+} \text {on resin }}{L \text { resin }}
\end{aligned}
$$

$4.134 \mathrm{~g} \mathrm{~K} / \mathrm{L}$ resin $\times 2,000 \mathrm{~L}$ resin $/ \operatorname{column}=8.27 \mathrm{~kg} \mathrm{~K} / \mathrm{column}$ $=212 \mathrm{eq} \mathrm{K} / \mathrm{col}$ umn

$$
\frac{212{\mathrm{gmole} \mathrm{K}^{+}}_{\text {column }}}{\text { gmole } \mathrm{K}^{+}}\left|\frac{39 \mathrm{~g} \mathrm{K^{+ }}}{1,000 \mathrm{~g}}\right| \frac{\mathrm{kg} \mathrm{K}}{\mathrm{NCAW}}=1.07 \times 10^{2} \frac{\mathrm{kg} \mathrm{K}}{\text { NCAW }}
$$

The amount of sodium that can be loaded is:

$3,140 \mathrm{eq} / \operatorname{column})-(194 \mathrm{eq} / \operatorname{column})-(212 \mathrm{eq} /$ column $)=2,946 \mathrm{eq} /$ column 


$$
\frac{2,946 \mathrm{gmole} \mathrm{Na}^{+}}{\text {column }}\left|\frac{23 \mathrm{~g} \mathrm{Na}^{+}}{\text {gmole } \mathrm{Na}^{+}}\right| \frac{\mathrm{kg} \mathrm{Na}^{+}}{1,000 \mathrm{~g}} \mid \frac{13 \mathrm{columns}}{\mathrm{NCAW}}=8.81 \times 10^{2} \frac{\mathrm{kg} \mathrm{Na}^{+}}{\mathrm{NCAW}}
$$

For DSSF :

Based on extrapolation of data in reference $A 1$, the potassium lambda was assumed to be 1 . That value was used to obtain the amount of potassium which would load onto the resin.

$$
\begin{aligned}
& \frac{1\left(g K^{+} \text {on resin }\right)(m L \text { soln })}{\left(g K^{+} \text {in soln }\right)(m L \text { resin })} \mid \frac{4.78 \times 10^{-1} \text { gmole } C s+i n \text { soln }}{L \text { soln }} \\
& \frac{L}{1,000 m L \text { soln }}\left|\frac{39 g K^{+}}{\text {gmole } K^{+}}\right| \frac{1,000 m L}{L \text { resin }}=18.6 \frac{g K^{+} \text {on resin }}{L \text { resin }}
\end{aligned}
$$

$18.6 \mathrm{~g} \mathrm{~K} / \mathrm{L}$ resin $\times 2,000 \mathrm{~L}$ resin $/$ column $=37.2 \mathrm{~kg} \mathrm{~K} /$ column

$$
=950 \mathrm{eq} \mathrm{K} / \mathrm{column}
$$

$$
\frac{950 \text { gmole } K^{+}}{\text {column }}\left|\frac{39 \mathrm{~g} \mathrm{~K}^{+}}{\text {gmole } \mathrm{K}^{+}}\right| \frac{\mathrm{kg} \mathrm{K}}{1,000 \mathrm{~g}} \mid \frac{272 \text { columns }}{\text { DSSF }}=1.01 \times 10^{4} \frac{\mathrm{kg} \mathrm{K}}{\text { DSSF }}
$$

The amount of sodium that can be loaded is:

$$
\begin{aligned}
& (3,140 \mathrm{eq} / \text { column })-(24 \mathrm{eq} / \text { column })-(950 \mathrm{eq} / \text { column })=2,166 \mathrm{eq} / \mathrm{col} u m n \\
& \frac{2,166 \mathrm{gmole} \mathrm{Na}}{\text { column }}\left|\frac{23 \mathrm{~g} \mathrm{Na}^{+}}{\text {gmole Na}}+\frac{\mathrm{kg} \mathrm{Na}}{1,000 \mathrm{~g}}\right| \frac{272 \mathrm{col} \text { umns }}{\text { DSSF }}=1.36 \times 10^{4} \frac{\mathrm{kg} \mathrm{Na}^{+}}{\text {DSSF }}
\end{aligned}
$$


WHC-SD-WM-TI-638 REV 0

\section{A3.0 ENERGY BALANCE}

This energy balance data was provided by B. J. Knutson of Westinghouse Hanford Company.

ENERGY BALANCE FOR R-F RESIN IX COLUMN SYSTEM--The resorcinolformaldehyde copolymer (R-F) resin is an organic resin similar to the Duolite CS-100 resin matrix, which is a phenol-formaldehyde condensate. Organic resins may be oxidized by $\mathrm{HNO}_{3}$, producing gas and heat. The oxidation rate increases with increasing temperature and will continue to increase exponentially if the heat of reaction is not dissipated. Column pressurization results from the increased gas temperature, increased liquid vapor pressure, and the collection of oxidation reaction products in confined space.

To determine the necessary venting and cooling capabilities of the ion exchange columns under accident conditions the energy balance considers the two main heating sources: (1) the decay heat associated with a column fully loaded with cesium (CS), and (2) the possible resin/ $/ \mathrm{HNO}_{3}$ reaction heat.

For the purpose of emergency venting requirements evaluation, the rapid charging of the resin bed with reagent grade $12.2 \mathrm{M}$ aqueous $\mathrm{HNO}_{3}$ solution is postulated. Under these accident conditions, the resin and concentrated $\mathrm{HNO}_{3}$ can react producing gas and heat which could lead to a catastrophic column failure. It was assumed that the $R-F$ resin reacts similar to the $C S-100$ resin when contacted by $\mathrm{HNO}_{3}$. Calculations for the $\mathrm{CS}-100$ resin showed that column cooling could not control the reaction (A4) and, therefore, addition of a column rupture disk was required to relieve reaction gases and to provide evaporative cooling through the rupture disk.

The calculation of reaction gas generation is also needed for proper column vent sizing. The column must be able to vent the reaction gases as quickly as they are produced. Inadequate venting and cooling could potentially lead to explosive conditions.

The cooling capacity of the IX columns should be able to meet two criteria: (1) to maintain each column below $50{ }^{\circ} \mathrm{C}$ ( $122{ }^{\circ} \mathrm{F}$ ) with a fully Cs-loaded column, and (2) to dissipate reaction heat to prevent boiling at approximate 7 y $100^{\circ} \mathrm{C}\left(212^{\circ} \mathrm{F}\right)$.

The data provided in Table A-9 is a summary of the results of the energy balance calculations. The FAI experiments were conducted at an elevated backpressure to supress vaporization and the associated "tempering" effect on the rate of reaction. Therefore, the gas generation rate does not include water vaporization. 
Table A-9. Energy Balance Calculations. (2 sheets)

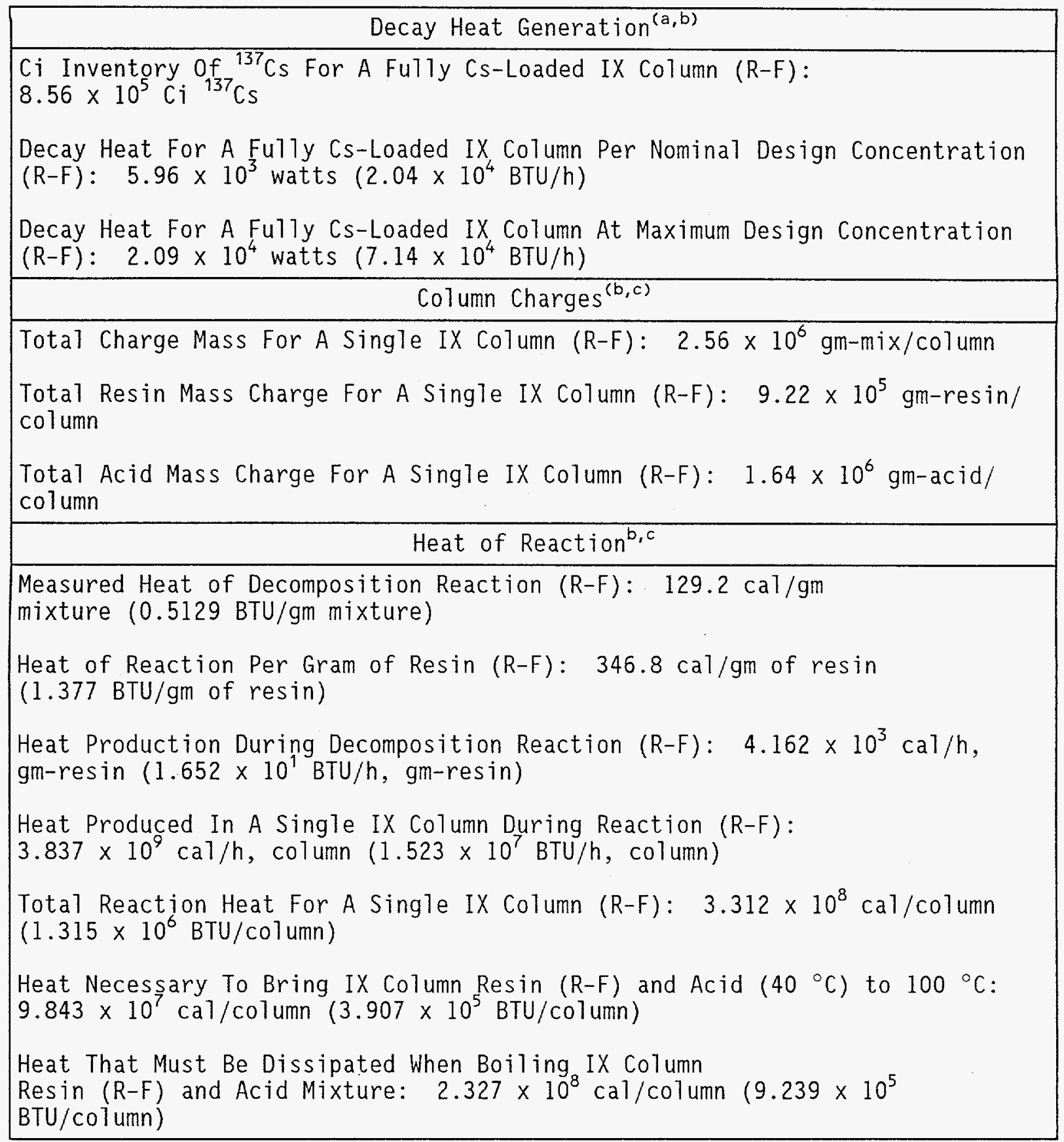


Table A-9. Energy Balance Calculations. (2 sheets)

\begin{tabular}{l} 
Reaction Gas Generation ${ }^{(b, c)}$ \\
\hline Test Average Gas Volume Generation Rate $(\mathrm{CS}-100): 5.64 \times 10^{-3} \mathrm{ft}^{3} / \mathrm{min} / \mathrm{gm}-\mathrm{mix}$ \\
Total Gas Volume Generation Rate For An IX Column $(\mathrm{CS}-100): 1.44 \times 10^{4}$ \\
$\mathrm{ft}^{3} / \mathrm{min} /$ column
\end{tabular}

(a) Energy Balance Calculational Assumptions and Measurement Data:

(a) Cesium physical property data:

Specific Activity: $86.6 \mathrm{Ci}{ }^{137} \mathrm{Cs} / \mathrm{g}^{137} \mathrm{Cs}^{\circ}$

Isotopic ratios: Neutralized Current Acid Waste (NCAW): $0.38 \mathrm{~g}^{137} \mathrm{Cs}^{\circ / \mathrm{g} \mathrm{Cs}}$ Double-Shell

slurry feed (DSSF): $0.25 \mathrm{~g}^{137} \mathrm{Cs}^{+/} \mathrm{g} \mathrm{Cs}^{+}$

Maximum ${ }^{137} \mathrm{Cs}$ decay energy of $1.176 \mathrm{MeV}\left(1.884 \times 10^{-13}\right.$ Joules or watt-sec $)$

(b) Preliminary Cs IX flowsheet data using $R-F$ resin:

Maximum allowed CS IX column concentration is 3 MCi from Section 6.4 of the B-Plant Safety Analysis Report

Maximum Cs resin loading concentration [CS] was for NCAW waste of $13.0 \mathrm{~g} \mathrm{CS}$ on resin/L of resin

Each IX column has a resin volume of $2,000 \mathrm{~L}$

Na-form resin was estimated to have a density of $461 \mathrm{gm}-r e s i n / L$ of resin Column elution

Temperature was assumed to be $40^{\circ} \mathrm{C}$

(c) Fauske and Associates, Inc. (FAI) experimental data:

For high back pressure Test A005-10:

Sample charge was $31.7 \mathrm{gm}$ resin (unirradiated CS-100 in Na form) and $53.4 \mathrm{gm}$ HNO, solution (assumed <12.2M)

Total test charge was $85.1 \mathrm{gm}$ mixture

Elapsed time from acid injection to completion of runaway reaction was 5 minute

Apparent heat of reaction was based on a maximum observed temperature rise of $161^{\circ} \mathrm{C}$

Measured $\mathrm{Na}$ form acid/resin mixture specific heat was $0.75 \mathrm{cal} / \mathrm{gm}^{\circ}{ }^{\circ} \mathrm{C}$

Measured Heat capacity of the $\mathrm{HNO}_{3} /$ resin mixture (reactants) was $0.64 \mathrm{cal} / \mathrm{gm}^{-}{ }^{\circ} \mathrm{C}$

A heat capacity factor of $1.07(1+$ mass heat capacity ratio of FAI test cell to sample) was appl icable

Acid solution to resin mass ratio was assumed to be approximately 1.78 based on IX column data provided to FAI

FAI data showed approximately 1 mole gas was generated per 1 mole $\mathrm{HNO}_{3}$

Major components of the gases produced from the resin/acid reactions were $\mathrm{CO}_{2}(\mathrm{MW}=44)$, NO $(\mathrm{MW}=30)$, and $\mathrm{NO}_{2}(\mathrm{MW}=46)$

Gas mixture average molecular weight was estimated as approximately 40

Measured FAI test average gas volume generation rate was $2.66 \mathrm{cc} / \mathrm{sec}$, total gm charge mass average test charge was $85.6 \mathrm{gm}$ mixture

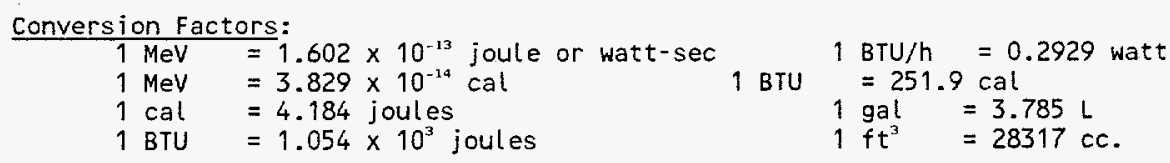




\section{A4.0 EQUIPMENT DESIGN}

\section{A4.1 COLUMN DESIGN}

\section{A4.1.1 Resin Bed Volume}

The resin bed size selected for this design has been selected to give an average design feed rate of $3 \mathrm{BV} / \mathrm{hr}$ (or a total online column retention time of 1 hour). Retention time is calculated in the sodium (loading) form of the resin. This selection was made based on the assumption that using this feed rate, less secondary waste would be generated, i.e., less $\mathrm{HNO}_{3}$, and $\mathrm{NaOH}$ would have to be used for the elution and regeneration steps. Since these chemicals could end up in the final high level waste form, this document assumes that minimizing these added waste volumes would out weigh other factors in the determination of the overall optimal ion exchange design.

Although the resin performance increases with decreasing feed rate, a feed rate of $3.0 \mathrm{BV} / \mathrm{h}$ is considered to be the minimum feed rate acceptable for engineering design, because the effects of radial mixing within the column below this feed rate are assumed to negate any benefit brought about be feeding slower.

A feed rate of $3 \mathrm{BV} / \mathrm{h}$ is relatively slow compared to other industrial applications of ion exchange. This feed rate was assumed to allow easier comparison with the CS-100 resin. A faster feed rate of about 9 BV/h may be used with the NCAW waste. However, the feed rate with the DSSF waste (and possibly with other waste types should be $3 \mathrm{BV} / \mathrm{h}$ to provide better loading of the resin.

$$
\text { average design flowrate: }
$$

total column retention time:

$$
\frac{100 \mathrm{~L}}{\min }\left|\frac{60 \mathrm{~min}}{h}\right| \frac{h}{1 \mathrm{CV}}=6,000 \mathrm{~L} \text { per total column volume }
$$

$100 \mathrm{~L} / \mathrm{min}$

$3 \mathrm{BV} / \mathrm{h}$

1 h ( 3 columns on 1 ine)

or $1,600 \mathrm{ga} 7$. In this case with a system of 3 columns online in series, the total online resin volume referred to above is the volume of the 3 online columns. The volume of the resin in each column is $2,000 \mathrm{~L}$, or $535 \mathrm{gal}$.

\section{A4.1.2 Column Dimensions}

The ion exchange system will consist of four 2,000 L (535 gal) columns. If a length to diameter ration (L/D) of 2.0 is assumed for this design the dimensions of the columns are as follows:

Resin bed aspect ratios (L/DS) of 2 are chosen for this design, other L/DS would be acceptable. The kinetics of both the CS-100 and the R-F resin with both NCAW and DSSF waste have been shown to be controlled primarily by diffusion in the particle phase (as opposed to film diffusion limited). This 
means that the L/D of the resin bed has no effect, on resin kinetics. Resin bed L/Ds should thus be designed based on an optimization of other mechanical factors such as minimization of pressure drop, minimization of channelling, facilitation of column cooling, minimization of radiation and heat build-up, minimization of resin exposure to radiation, minimization of mass of potentially reactive chemicals, optimization of facility space, and minimization of construction costs.

A "rule of thumb" developed by Helfferich et. al. (1994) (A8) states that columns should have bed aspect ratios of between 2 and 7 . For 1 arge columns aspect ratios as low as 1 may be used, however, columns with aspect ratios of less than one tend to give poor performance. In low aspect ratio beds, it is difficult to distribute the feed evenly over the area of the bed. The feed will tend to channel more easily, especially down the middle of the column, resulting in an under-utilized bed. As bed aspect ratio increases so does pressure drop.

$$
V=\frac{\pi}{4} D^{2} L
$$

where $V$ is the volume of a single resin bed or 2,000 L (535 gal).

$$
\begin{array}{r}
\frac{2,000 \mathrm{~L}}{\mathrm{~L}}\left|\frac{1,000 \mathrm{~mL}}{\mathrm{~L}}\right| \frac{\mathrm{cm}}{\mathrm{mL}}=\frac{\pi}{4} \mathrm{D}^{2} \\
D=\sqrt[3]{\frac{2(2,000)(1,000)}{\pi}} \\
D=108 \mathrm{~cm} \quad(43 \mathrm{in.}, \text { or about } 3.5 \mathrm{ft}) \text { in diameter }
\end{array}
$$$$
L=213 \mathrm{~cm} \text { (85 in., or about } 7 \mathrm{ft} \text { ) tall }
$$ 


\section{A5.0 REFERENCES}

(Al) Kurath, D. E., Bray, L. A., Brooks, K. P., Brown G. N., Bryan S. A., Carlson C. D., Carson K. J., DesChane J. R., Elovich R. J., and A. Y. Kim, TWRSPP-94-010, Experimental Data and Analysis to Support the Design of an Ion Exchange Process for the Treatment of Hanford Tank Waste Supernatant Liquids, January, 1994, Prepared for Westinghouse Hanford Company, by Pacific Northwest Laboratory, Richland, Washington.

(A2) Perry, R. H., D. W. Green, Perry's Chemical Engineers' Handbook, sixth edition, 1984, McGraw-Hi11, New York.

(A3) Bray, L. A., Elovich, R. J., and K. J. Carson, PNL-7273/UC-510, Cesium Recovery Using Savannah River Laboratory Resorcinol-Formaldehyde Ion Exchange Resin, March 1990, prepared by Pacific Northwest Laboratory, Richland, Washington.

(A4) Gale, L. A. to W. E. Poling, April 1987a, Cooling Requirements For The Cel7 18 Ion Exchange Column, Letter 65920-87-041, Apri1 7, 1987.

(A5) Grelecki, C. to L. A. Gale, July 1987, HRC Project 6411, Hazards Research Corporation, Rockaway, New Jersey, Ju7y 16, 1987.

(A6) Fauske \& Associates, Inc. December 1989, Revised Verification of the Rupture Disk Design For The Cel7 18 Ion Exchange Column, Type IV, FAI/89-51, December 1989.

(A7) Gale, L. A., July 1987b, Preliminary Design of the Cell 18 Cesium/Nitric Acid Ion Exchange System, WHC-SD-WM-TI-311, JuTy 31, 1987.

(A8) Helfferich, F. G., et. al., Text from the AIChE Today Series, Ion Exchange Theory and Practice, American Institute of Chemical Engineers, 1992, New York, New York. 
WHC-SD-WM-TI-638 REV 0

\section{APPENDIX B}

SELECTION OF CS-100 RESIN AS BASELINE ION EXCHANGER 
WHC-SD-WM-TI-638 REV 0

This page intentionally left blank. 
APPENDIX B

\section{SELECTION OF CS-100 RESIN AS BASELINE ION EXCHANGER}

Duolite ${ }^{\mathrm{TM}}$ CS-100 has been chosen as the baseline ion exchange material for cesium removal from Hanford tank waste. CS-100 resin is a proven commercially available performer for cesium removal in nuclear applications. Tests with Hanford, Savannah River, and West Valley waste simulants indicate that CS-100 resin has one of the highest capacities for cesium of the commercially available ion exchangers tested, and is capable of meeting TWRS cesium removal goals. The R-F resin is not considered "commercially available" at this time.

Very few commercially available ion exchange materials can match the performance of CS-100 in cesium removal. Unlike most inorganic ion exchange materials CS-100 is very resistant to high alkaline conditions. Unlike many other organic resins CS-100 is very resistant to acids, and high radiation. Mild acids readily elute cesium from the resin. CS-100 has been shown to maintain it's cesium sorption performance very well after multiple chemical cycles between the hydrogen and sodium forms. The following summaries of key documented studies are listed in chronological order and support the selection of CS-100 resin as the baseline ion exchanger. A comparison of exchanger performance relative to CS-100 resin is summarized in Table B-4 at the end of Appendix B.

\section{Wiley 1975, Savannah River}

Tests were performed at Savannah River in 1975 (Wiley 1975) with ARC-359 resin and simulated and actual Savannah River alkaline supernate to support development of a cesium removal process.

Cesium equilibrium distribution coefficients, column breakthrough curves, and decontamination factors (DF) were determined for cesium-ARC-359 with the Savannah River simulant (SRS). Cesium elution curves were developed using ammonium carbonate/ammonium hydroxide solution as eluant.

For a simulated waste solution with $4.75 \mathrm{M} \mathrm{NaNO}_{3}, 1 \mathrm{M} \mathrm{NaOH}$, and $2 \times 10^{-4} \mathrm{Cs}$ the $50 \%$ breakthrough curve was about 30 column volumes (CV). A cesium DF of $>10^{4}$ was obtained with $25 \mathrm{CV}$ of feed. The loaded cesium was effectively eluted with $12 \mathrm{CV}$ of eluate. Seven complete load-elute-regenerate cycles were completed during which, no deterioration of resin performance was noticed.

Simulated supernate was spiked with potassium to measure it's effect on cesium removal. Addition of $0.01 \mathrm{M} \mathrm{KNO}_{3}$ had $1 \mathrm{ittle}$ effect on cesium removal while $0.06 \mathrm{M} \mathrm{KNO}{ }_{3}$ reduced by about $20 \%$ the number of column volumes that could be processed. 
Column tests with actual Savannah River waste were run and DFs were determined. In all tests DFs of $10^{4}$ or greater were obtained with $10 \mathrm{CV}$ of feed. The columns were eluted with ammonium carbonate/ammonium hydroxide solution and elution curves were developed. About 95\% of the 1oaded cesium was removed with $8 \mathrm{CV}$ of $2 \mathrm{M}\left(\mathrm{NH}_{4}\right)_{2} \mathrm{CO}_{3}-2 \mathrm{M} \mathrm{NH} \mathrm{NH}_{4} \mathrm{OH}$.

ARC-359 resin was digested in a solution of $0.1 \mathrm{M} \mathrm{HNO}$ acid and $6 \% \mathrm{H}_{2} \mathrm{O}_{2}$ at $80^{\circ} \mathrm{C}$. The resin dissolved completely in about 1 hour.

\section{Baumgarten 1979, Savannah River}

More tests were performed with ARC-359 resin at Savannah River (Baumgarten, Wallace, Whitehurst, and Steed 1979) to support development of a process to remove cesium from alkaline supernate. DFs of $>10^{4}$ were obtained from a 1978 batch of ARC-359 resin at breakthrough points of between 20 to 60 column volumes of feed processed. Three different batches of ARC-359 resin were tested. Batches made in 1973, and 1977 showed about half the capacity of a 1978 batch. The reduced capacity of the 1973 batch was attributed to deterioration over time. The reduced capacity of the 1977 batch was not explained. Fresh eluant spiked with some cesium was used successfully as an eluant to prove that eluate could be recycled.

\section{Wallace and Ferguson 1980, Savannah River}

A change in baseline process was proposed at Savannah River to remove cesium from alkaline waste. The new process involves sorbing cesium onto either Duolite CS-100 or Duolite S-671 resin. The reported advantages of using CS-100 or S-671 which are phenolic resins, would be that they both can be eluted with formic acid which would eliminate and simplify overall processing steps compared to the use of ammonium carbonate elution which is necessary with ARC-395 resin. Savannah River was considering addition of formic acid as a reductant in the HLW vitrification system. Formic acid eliminated the need for an ammonia carbonate recovery system.

Tests were conducted with CS-100 and S-671 to support this process (Wallace and Ferguson 1980). The tests obtained cesium equilibrium distribution coefficients for cesium from a simulated waste solution containing $4.75 \mathrm{M} \mathrm{NaNO}_{3}$, and $1 \mathrm{M} \mathrm{NaOH}$, breakthrough curves from a feed containing $5.65 \mathrm{M} \mathrm{Na}^{+}, 2.36 \times 10^{-4} \mathrm{M} \mathrm{Cs}^{+}, 1.67 \mathrm{M} \mathrm{NO}_{3}^{-}, 0.94 \mathrm{M} \mathrm{NO}_{2}^{-}, 1.67 \mathrm{M} \mathrm{OH}^{-}$, $0.52 \mathrm{M} \mathrm{AlO}{ }_{2}^{-}, 0.21 \mathrm{M} \mathrm{CO}_{3}^{2-}$, and $0.22 \mathrm{M} \mathrm{SO}_{4}^{2-}$. CS-100 was chosen for further development because of it's greater breakthrough capacity and because it also sorbs strontium to some extent. The sorption characteristics of both CS-100 and S-671 were shown to be very similar to those of ARC-359.

Batch equilibrium tests with $\mathrm{ARC}-359, \mathrm{CS}-100$, and $\mathrm{S}-671$ in both $2 \mathrm{M}\left(\mathrm{NH}_{4}\right)_{2} \mathrm{CO}_{3}-1 \mathrm{M} \mathrm{NH} \mathrm{OH}$, and in $2 \mathrm{M}$ formic acid showed the following: Cesium should elute from CS-100 and S-671 more efficiently with ammonium carbonate than from ARC-359. Cesium should elute from CS-100 and S-671 with 2 M formic acid more efficiently than with ammonium carbonate, but it should not elute well from ARC-359 with formic acid. The elution performance of S-671 should be slightly better than CS-100 with both eluants. 
Column elution curves for CS-100, and S-671 resins, using $2 \mathrm{M}$ formic acid were nearly identical. Cesium was eluted from the CS-100, and S-671

effectively in about 4 column volumes of $2 \mathrm{M}$ formic acid. The column elution curve for $\mathrm{CS}-100$ with $2 \mathrm{M}\left(\mathrm{NH}_{4}\right)_{2} \mathrm{CO}_{3}-1 \mathrm{M} \mathrm{NH}$ with formic acid. A strontium elution curve was developed for CS-100 elution with $2 M$ formic acid. It was similar to the cesium/CS-100/formic acid elution curve indicating that strontium should elute well from CS-100 with formic acid.

\section{Baumgarten, Ebra, Kilpatrick, and Lee 1981, Savannah River}

In 1981 the baseline process for removing cesium from Savannah River supernate consisted of two beds of CS-100 resin with formic acid elution. Column loading and elution tests were performed to develop breakthrough and elution curves with CS-100 resin and a Savannah River simulant with $2.5 \times 10^{-4}$ $M$ total cesium (Baumgarten, Ebra, Kilpatrick, and Lee 1981). The cesium breakthrough curves agree with previous tests. The report estimates that assuming a goal of $90 \%$ cesium retention in the first column, between 40 and 60 column volumes of throughput can be handled at a feed rate of 1.6 column volumes per hour. By extrapolating to a DF of 10,000, the breakthrough volume of the second column was estimated at between about 60 and 80 bed volumes with $40-60$ mesh resin.

Column loading tests were performed with CS-100 resin of different size distributions. These tests showed that resin performance improved significantly in going from $20-40$ mesh to $40-60$ mesh, but the test with a further size reduction (60 - 80 mesh) showed no further improvement.

The elution data showed that approximately $98 \%$ of the cesium was eluted from the loaded column with about 16 bed volumes of $0.2 \mathrm{M}$ formic acid.

\section{Chilton, 1981, Oak Ridge National Laboratory}

In Tests at Oak Ridge National Laboratory (ORNL) (Chilton, 1981), CS-100 resin was tested with actual ORNL low-level alkaline liquid waste which contained cesium-137. Column tests were run with and without sodium hydroxide regeneration. The results showed that the omission of the $\mathrm{NaOH}$ regeneration step did not significantly effect the loading performance of the resin. However, omission of the $\mathrm{NaOH}$ regeneration step did cause an increase in the pressure drop across the resin bed, presumably due to "packing" of the bed caused by swelling of the bed during downflow loading. Bed regeneration is normally accomplished upflow, allowing the bed to expand upward thus preventing "packing". Due to these experimental results plant operations were changed to use stoichiometric amounts caustic for regeneration instead of $100 \%$ excess, as was done formerly.

Repeated loading/elution/regeneration cycles were run with $C S-100$, real ORNL low-level alkaline liquid waste, $0.5 \mathrm{M}$ nitric acid as eluant, and $0.1 \mathrm{M} \mathrm{NaOH}$ as regenerant. The loading performance was found to be significantly reduced after 20 loading/elution cycles; one-fourth or less of the original capacity was retained after 30 cycles. 
Strontium was shown to load on CS-100 resin in a column to some extent.

Elution tests showed that elution with 10 bed volumes of 0.5 M nitric acid removed an average of over $99 \%$ of the loaded activity. The cesium elution performance of acetic, and formic acids of varying concentrations was compared to $0.5 \mathrm{M}$ nitric acid. Greater volumes of equal concentration acetic and formic acids were needed to achieve $99 \%$ cesium removal from the resin as compared to nitric acid. Formic acid eluted the cesium more efficiently than the acetic acid.

Ebra, Wallace, Walker, and Wille, 1981, Savannah River

A new resorcinol-formaldehyde resin was developed at Savannah River and found to have a cesium selectivity of 5-10 times higher than CS-100 resin based on batch contacts with synthetic Savannah River Site waste (Ebra, Wallace, Walker, and Wille, 1981). Column experiments demonstrated the R-F resin can process about 4 times more bed volumes of simulant waste than CS-100 at $1 \%$ breakthrough.

Bray, et. a1., 1983, Pacific Northwest Laboratory

Laboratory scale experiments were conducted with CS-100 resin, ARC-359 resin, Ionsiv IE-95 (inorganic), AW-500 (inorganic), and a simulant of West Valley alkaline waste supernate ( $\mathrm{pH} 10.4$ to 13.8), in support of a proposed cesium removal process (Bray, et. al., 1983). follows:

Batch cesium distribution ratios were developed at $\mathrm{pH} 10$ and 13 as

Table B-1. Batch $R_{d}$ Values for Cesium for Various Exchangers

\begin{tabular}{|c|c|c|c|c|}
\hline $\mathrm{pH}$ & AW-500 & IE-95 & CS-100 & ARC-359 \\
\hline 10 & 41 & 36 & 14 & 12 \\
\hline 13 & 37 & 31 & 34 & 24 \\
\hline
\end{tabular}

The batch sorption tests showed that CS-100 was a viable candidate for ion exchange column testing, and that an inorganic exchanger should also be studied. The results showed that the CS-100 performance was found to be dependent upon particle size, temperature, and feed $\mathrm{pH}$. Higher loadings were achieved at smaller resin particle size. Loadings improved by a factor of 3.5 when temperature was 10 wered from $50^{\circ} \mathrm{C}$ to $6^{\circ} \mathrm{C}$.

The CS-100 resin was found to perform better at high $\mathrm{pH}$ with the West valley simulant. At a pH of $13.8,6$ bed volumes of feed were loaded at a cesium breakthrough $C / C_{0}$ of 0.1 , as opposed to only 1 bed volume of feed loaded at a pH of 10.4. At a feed pH of 13.8 the highest cesium DF the CS-100 resin achieved was $\sim 1600$. 
Performance of IE-95 inorganic exchanger with Waste Valley waste simulant was found to be dependent on temperature, flow rate, $\mathrm{Na}^{+} / \mathrm{Cs}^{+}$ratio, and $\mathrm{pH}$. Cesium loading improved by a factor of 1.5 as temperature was decreased to $50^{\circ} \mathrm{C}$ to $60^{\circ} \mathrm{C}$ at $0.01 \mathrm{C} / \mathrm{C}$. Cesium 70 ading increased by a factor of 1.4 as the feed $\mathrm{pH}$ decreased from 13.8 to 10.4. Ejght bed volumes of feed was processed through the IE-95 at a cesium DF of $>10^{4}$, flow rate of 0.6 bed volumes per hour, $\mathrm{pH}$ of 10.4 and temperature of $25^{\circ} \mathrm{C}$.

The cesium loading capacity of IE-96 at $\mathrm{pH} 10.4$ was found to be greater than that of $\mathrm{CS}-100$ at $\mathrm{pH} 13.8$ by a factor of 3 . It was determined that the use of CS-100 would not meet minimum cesium requirements to make a class $A$ waste at either $\mathrm{pH}$ of 10.4 or 13.8 , while the use of IE-95 would meet the cesium removal requirements at a pH of 10.4 but not at a $\mathrm{pH}$ of 13.8 . AW-500 and IE-95 are zeolites and not suitable for treating Hanford Site tank waste. They decompose when exposed to strong alkaline solution ( $\geq 1 \mathrm{MOH}$ ).

\section{Weiss, 1985, Rockwe11 Hanford Operations}

A test plan was developed to investigate several ion exchangers for cesium removal use in B-Plant (Weiss, 1985). The goal was to find a replacement for ARC-359 which was no longer manufactured. There was also desire to eliminate the use of ammonium carbonate as a eluant. The presence of ammonium was reported to create problems with waste handling in the plant. The following ion exchangers were chosen for study:

$\begin{array}{ll}\text { Name } & \text { Manufacturer } \\ \text { Durasil } 10 & \text { Duratek Corporation } \\ \text { Durasil 210 } & \text { Duratek Corporation } \\ \text { Vitrokele 55 } & \text { Devoe Holbein } \\ \text { Duolite CS-100 } & \text { Rohm \& Haas } \\ \text { Duolite ES-286 } & \text { Rohm \& Haas } \\ \text { Zeolon } 900 & \text { Norton Company }\end{array}$

Hazards Research Corporation, 1986

A proposal to assess the reaction potentials of various mixtures of nitric acid (12.2 - $1.5 \mathrm{M})$ and $\mathrm{CS}-100$ resin was written by Hazards Research Corporation and submitted to Rockwell Hanford Operations (Hazards Research Corporation, 1986).

Gale, 1986

In a report of meeting minutes (Gale 1986) it was reported that analysis of recent batch contact data indicated that the CS-100 resin manufactured after 1982 (the current manufacturing process) appeared to have about half the capacity of the CS-100 resin manufactured before 1982. Diamond Shamrock (now Rohm and Haas) changed the manufacturing process in 1982. 


\section{Gallagher, 1986, Rockwell Hanford Operations}

A series of tests was conducted in 1986 in support of a cesium ion exchange process flowsheet (Gallagher, 1986). The proposed process was to be located in Hanford's B-Plant. Seven potential ion exchangers were selected for batch contact tests. The following data was obtained with an NCAW simulant:

Table B-2. Ion Exchanger/NCAW Simulant Batch Contact Data

\begin{tabular}{|c|c|}
\hline Ion Exchanger & $\begin{array}{c}\text { grams of cesium absorbed } \\
\text { per gram exchanger }\end{array}$ \\
\hline Zeolon 900 & 0.0055 \\
\hline Duolite ARC-9359 & 0.0035 \\
\hline Duolite CS-100 & 0.0025 \\
\hline Durasi1 10 & 0.0009 \\
\hline Durasi1 210 & 0.0009 \\
\hline Vitroke1e 55 & trace \\
\hline Duolite ES-286 & trace \\
\hline
\end{tabular}

Based on this data and because neither Zeolon 900 nor ARC-9359 were being manufactured at that time, only CS-100 resin was selected for further tests. Another advantage noted for CS-100 was that it was resistant to acids, bases and radiation.

Multiple cycle column runs were then run using CS-100 resin, an NCAW simulant, and either nitric acid or ammonium carbonate solution as eluant. Significant off gassing was noticed when $1 \mathrm{M} \mathrm{HNO}_{3}$ eluant was used. The gassing problem occurred during the $0.5 \mathrm{M}$ and $2.0 \mathrm{M} \mathrm{NaOH}$ solution regeneration steps following acid elution. It was believed that the gassing was due to the residual strong acid reacting with strong base in the column. The gassing was avoided by changing to a weaker $0.5 \mathrm{M} \mathrm{HNO}_{3}$ eluant solution, and by increasing the volume of water wash between elution and regeneration.

Forty-five bed volumes of the $1.94 \mathrm{M} \mathrm{Na}^{+}, 7.37 \times 10^{-4} \mathrm{M} \mathrm{Cs}^{+}$, NCAW simulant feed were passed through fresh CS-100 resin at $3 \mathrm{BV} /$ hour with a cesium loss of 0.7 percent of the total cesium originally in this volume (i.e. $99.3 \%$ cesium capture). Six bed volumes of $0.5 \mathrm{M} \mathrm{HNO}_{3}$ eluant removed $99.3 \%$ of the loaded cesium.

Two runs were made without first converting the resin from the hydrogen form to the sodium form. In both cases precipitation of aluminum containing solids was observed. 
A synthetic solution was prepared corresponding to the composition of the eluate. This solution was concentrated by evaporation to between 2.55 to $2.06 \mathrm{M}$ sodium. The $\mathrm{pH}$ of this solution was then adjusted to 10 with either $0.5 \mathrm{M} \mathrm{NaOH}$ or $19.4 \mathrm{M} \mathrm{NaOH}$. Attempts were made to raise the $\mathrm{pH}$ of the eluate using Duolite MSA-1, Amberlite IRA 900, Amberlite IRA 99, and Amberlite IRA 400, anion exchange resins by batch contact. None of the anion exchange resins raised the $\mathrm{pH}$ to the desired value of 10 .

Tests were performed to support a "second cycle" of the baseline B-Plant cesium removal flowsheet. The "second cycle" would consists of processing the neutralized cesium rich eluate of the "first cycle" of cesium ion exchange through another cesium ion exchange cycle with a bed of CS-100 resin. The purpose of the "second cycle" was to further concentrate the cesium by separating the cesium from sodium.

Tests were performed to support an ammonium carbonate e]uted CS-100 B-Plant cesium removal flowsheet.

CS-100 resin chemical degradation was measured by placing a known mass of the resin in volumes of $1 \mathrm{M}$ and $6 \mathrm{M} \mathrm{HNO}_{3}$ for one month at room temperature. No significant weight loss was noticed from the 1 M $\mathrm{HNO}_{3}$ test, about $30 \%$ of the original resin mass was lost in the $6 \mathrm{M} \mathrm{HNO}_{3}$ test.

Batch contact test were performed on samples of CS-100 irradiated to $10^{7}$, and $10^{8}$ rad. The data shows that cesium capacity is not significantly effected by up to $10^{8}$ rad under these conditions. The cesium capacities data were as follows:

\section{Sample}

unirradiated CS-100

CS-100 radiated to $10^{7} \mathrm{rad}$

CS-100 radiated to $10^{8} \mathrm{rad}$

\section{$\mathrm{g} \mathrm{Cs}^{+} / \mathrm{g}$ resin}

0.012

0.012

0.010

\section{Gibson and Landeene, 1986, Rockwe11 Hanford Operations}

A flowsheet was developed to support the demonstration processing of NCAW in B-Plant for separation of TRU bearing solids, and cesium from the supernate (Gibson and Landeene, 1986). The cesium removal flowsheet consisted of a single 2,687 liter bed of CS-100 resin designed to remove more than $95 \%$ of the cesium. A sodium scrub with $0.1 \mathrm{M} \mathrm{NaOH}$ prior to elution was to remove most of the sodium from the resin while removing only a small fraction of cesium. Cesium elution from the resin was with $0.3 \mathrm{M} \mathrm{HNO}_{3}$. A second cycle of cesium ion exchange was included to further separate the cesium from sodium. 
A nitric acid solution was selected as the baseline eluant based on the following identified advantages over an ammonium carbonate/ammonium hydroxide solution eluant:

- Ammonium interfered with cesium removal (removal was by cesium ion exchange) in the concentrator condensate stream.

- Ammonium in condensate effluents was a regulatory problem for disposal in cribs.

- Potential flammability concerns associated with the use of ammonium were eliminated.

- Less labor was estimated to be required with a nitric acid eluant.

- Nitric acid could be recycled to minimize eluant make-up requirements.

The following disadvantages associated with the nitric acid eluant were also identified:

- Two ion exchange cycles are required to meet $\mathrm{B}-\mathrm{Plant}$ flowsheet storage requirements and to get a favorable $\mathrm{Na}^{+}$content for $\mathrm{HLW}$ glass.

- Potential exothermic reaction hazards are associated with the use of nitric acid and organic resin.

- Product $\mathrm{Na}^{+} / \mathrm{Cs}^{+}$ratio is too high for previous purification/encapsulation flowsheet.

\section{Gale, 1987, Rockwell Hanford Operations}

A series of tests were conducted with CS-100 resin and nitric acid in 1987 in an attempted to answer questions regarding any potentially hazardous reactions (Gale 1987a). CS-100 resin in the hydrogen and NCAW treated forms were reacted with concentrations of nitric acid ranging from 0.5 to $12.0 \mathrm{M}$. Temperature and gas generation was measured versus time. Reaction off-gas composition was determined. Irradiated and non-irradiated resin was tested.

Little or no heat or gas was generated for $\mathrm{HNO}_{3}$ of 0.5 to $3.05 \mathrm{M}$. Hydrogen form resin was shown to be more reactive than NCAW treated (mostly sodium) form resin. Unirradiated resin was slightly more reactive than irradiated resin. The predominant gasses generated were carbon dioxide $\left(\mathrm{CO}_{2}\right)$, and nitric oxide (NO). No generation of hydrogen $\left(\mathrm{H}_{2}\right)$ or oxygen $\left(\mathrm{O}_{2}\right)$ was observed. 
Gallagher, 1987 Rockwel1 Hanford Operations

Column tests were performed with CS-100 resin from both pre and post 1982 batches. The cesjum capacity of the post 1982 CS-100 resin was determined to be only $78 \%$ of that of the pre 1982 resin.

\section{Gale, 1987, Westinghouse Hanford}

A preliminary design was done for the NCAW/B-Plant cesium removal flowsheet (Gale, 1987b). The design included a nitric acid scrub and elution. A single column containing 9,350 liters of $C S-100$ resin was to be used. A nitric acid dilution and addition system was included. A large rupture disk on the ion exchange column vessel was included to relieve reaction gasses, and cool the column in the event of a nitric acid/resin reaction.

\section{Gibson and Landeene, 1987, Westinghouse Hanford}

Revision A-1 of the B-Plant Flowsheet (Gibson and Landeene, 1987) was issued. The revision incorporated current data from testing of CS-100 resin, and updated flowsheet design information.

\section{Landeene, 1989, Westinghouse Hanford}

Based on more recent sample analysis data, the NCAW simulant recipe was changed (Landeene, 1989). The sodium to cesium ratio was changed from 2,600 to 11,400 . Cations of potassium, rubidium, and ruthenium were added. These cations could potentially compete with cesium for ion exchange sites on the CS-100 resin and reduce the predicted performance of the cesium removal process step.

\section{Prignano, 1989a, Westinghouse Hanford}

Due to uncertainty of the availability and variability of CS-100 resin which is being proposed resin for use in the B-Plant flowsheet for cesium removal from NCAW, three additional resins were tested for comparison (Prignano, 1989a). The resins tested were Duolite CS-100, Duol ite C-3, Duol ite $A R C-359 N$, and a resorcinol formaldehyde $(R-F)$ resin recently developed at Savannah River. Batch contact data in an NCAW simulant, and in nitric and formic acid was obtained.

The batch loading coefficients were obtained with the NCAW simulant and were reported as follows:

$\begin{array}{ll}\text { Resin } & \mathrm{mL} / \mathrm{g} \\ \mathrm{R}-\mathrm{F} & 1500 \text { to } 3000 \\ \mathrm{CS}-100 & 130 \\ \mathrm{C}-3 & 130 \\ \text { ARC-359N } & 25\end{array}$


Nitric acid eluted most of the loaded cesium from both the CS-100 and the $\mathrm{R}-\mathrm{F}$ resins. Under similar conditions formic acid also worked well for CS-100 resin but only eluted half of the loaded cesium from the R-F resin. Both $C-3$, and $A R C-359 \mathrm{~N}$ resins showed poor elution with nitric acid solution. $C-3$ and $A R C-359 \mathrm{~N}$ resins both contain strongly acidic sulfonate groups, and as a result, can not be eluted with formic acid.

\section{Prignano, 1989b, Westinghouse Hanford}

Another set of tests was conducted with the same four resins; Duolite CS-100, Duolite C-3, Duolite ARC-359N, and the resorcinol formaldehyde (R-F) (Prignano, 1989b). In this set of tests the resins were previously irradiated. As in the previous set of tests, batch contact data in an NCAW simulant, and in nitric and formic acid was obtained. The R-F resin was the only resin that appeared to be affected by radiation. The other three resin a11 irradiated to $10^{7} \mathrm{rad}$, showed performance similar to that of the non-irradiated resin. The $R-F$ resin was irradiated in three batches, one batch to $10^{6} \mathrm{rad}$, another batch to $10^{7} \mathrm{rad}$, and another batch to $10^{8} \mathrm{rad}$. The batch irradiated to $10^{7}$ rad showed cesium loading performance similar to that of the non-irradiated batch, which was far superior to the other three resins. The $\mathrm{R}-\mathrm{F}$ batch irradiated to $10^{6}$ rad showed a significant decreased in cesium adsorption performance, and the $10^{8}$ rad batch showed an even greater decrease in performance. The results were reproducible. The apparent discrepancy is unexplained.

Very little change in elution performance with acids was seen for most of the resin batches due to irradiation. The biggest difference was for the R-F batch irradiated to $10^{8}$ rad for which only $60 \%$ of the loaded cesium was removed with nitric acid. For the other batches of R-F resin closer to $90 \%$ was eluted.

\section{Prignano, 1989c and 1989d, Westinghouse Hanford}

A Taboratory scale model of the proposed B-Plant process for removing cesium from NCAW was used to test the effects of cycling and aging of resin (Prignano, 1989C). Previously irradiated CS-100 resin was used for the tests with an NCAW simulant feed. A single column loaded with $20 \mathrm{~m} 7$ of $\mathrm{CS}-100$ resin was used. Table B-2 describes the solutions and solution volumes that were fed to the column each cycle. Cycles were run one after the other with the same resin. A flow rate of 6 bed volumes per hour was used for all solution feeds. 


\begin{tabular}{|c|c|c|}
\hline \multicolumn{2}{|c|}{ Table B-2. } & \multicolumn{2}{c|}{$\begin{array}{c}\text { Column Test Solution Volumes and } \\
\text { Compositions }\end{array}$} \\
\hline Process Step & Solution & Bed Volumes \\
\hline regeneration 1 & 0.5 M NaOH & 1 \\
\hline regeneration 2 & 2.0 M NaOH & 2 \\
\hline flush & water & 4 \\
\hline feed & NCAW simulant & 17 \\
\hline flush & water & 2 \\
\hline Na $^{+}$scrub & 0.1 M HNO & 8 \\
\hline elution & 0.3 M HNO & 8 \\
\hline flush & water & 4 \\
\hline
\end{tabular}

Fifty-five cycles were completed. The results indicate that during any cycle 1ess than $2.0 \%$ of the total cesium fed passed through the columns un-adsorbed by the resin ( $D F>50$ ). Some cesium was noted in the column effluents of the sodium scrub solutions, particularly after a delay between cycles. Smal] quantities of cesium were seen in the water flushes. Over the 7 ife of the test, the maximum $\mathrm{Cs}^{+}$capacity of the resin decreased approximately 40 percent, from $0.0035 \mathrm{~g} \mathrm{Cs}^{+} / \mathrm{g}$ resin to $0.0021 \mathrm{~g} \mathrm{Cs} / \mathrm{g}$ resin after cycling. There was a noticeable decrease in the size of the resin particles at the end of the 55 cycles. The column test demonstrated $C S-100$ resin was still effectively sorbing cesium.

\section{Fauske and Associates, 1989, Prepared for Westinghouse Hanford Company}

Reaction tests were performed with $\mathrm{CS}-100$ resin and $12.2 \mathrm{M} \mathrm{HNO}_{3}$. The ratio of acid to resin was $1.16 \mathrm{ml}$ acid/g resin and $1.37 \mathrm{~m} 7$ acid/g resin (Fauske and Associates, Inc., 1989). The tests results confirm that the planned design of a 24 inch vent for the B-Plant cell 18 cesium ion exchange column is adequate. The results of this test have been questioned due to the possible use of a less concentrated acid than was originally assumed.

\section{Kurath, et al., 1990, Pacific Northwest Laboratory}

An ion exchange process which removes cesium from the supernate associated with neutralized PUREX high-level waste at the West Valley Demonstration Project was developed at Pacific Northwest Laboratory using a combination of laboratory testing with waste simulants and mathematical modeling. A study compares the performance of the actual process operation with those predicted by the laboratory studies with waste simulants and mathematical models (Kurath, et. a1. 1990). 
WHC-SD-WM-TI-638 REV 0

Breakthrough curves from actual operations were nearly identical as those predicted from laboratory work. Cesium distribution coefficients calculated from the first four actual operation runs averaged 35, which agreed well with the laboratory predicted value of 36 .

The usefulness of laboratory development of the ion exchange process was demonstrated by the correlation between the laboratory data and the process scale results.

\section{Deere, 1990, Westinghouse Hanford}

Radiation exposure rates and integrated doses from predicted cesium loadings of the proposed B-Plant cesium ion exchange column were calculated based on the B-Plant flowsheet (Deere, 1990). The worst case cesium loading scenario for the first cycle was estimated as $240 \mathrm{KCi}$ \& 45 hours. The average integrated dose for the resin at the center of the column for the first cycle was estimated as $1.55 \times 10^{6} \mathrm{rad}$. The average cesium loading for the first cycle was estimated as $240 \mathrm{KCi}$ at 35 hours.

\section{Buckingham, 1991a, Westinghouse Hanford}

Data was taken to recheck the performance of irradiated $R-F$ resin, and to expand the study of CS -100 resin (Buckingham 199la).

Irradiation changed the physical appearance of the R-F resin. After $10^{6}$ and $10^{7}$ rad the $R-F$ resin appeared to be stickier. It seemed to agglomerate into friable clumps. The R-F resin irradiated to $10^{8}$ rad appeared much 1 ike the unirradiated resin. The irradiated CS-100 resin showed no obvious physical change upon radiation. The data showed that radiation decreased the cesium sorption capacity of R-F resin by about 70 percent at $10^{6}$ and $10^{7}$ rad. However at $10^{8}$ rad the capacity of the R-F resin only decreased about 30 percent. Batch contacts with the loaded resin and $3.0 \mathrm{M} \mathrm{HNO}_{3}$ indicated no noticeable loss in elution performance at the $10^{6}, 10^{7}$, and $10^{8}$ rad exposures.

\section{Buckingham, 1991b, Westinghouse Hanford}

By varying the batch contact time, preliminary kinetic data was obtained for CS-100 with an NCAW simulant (Buckingham, 1991b). The data showed that maximum cesium adsorption on CS-100 resin takes around two hours residence time. Based on this data column runs with flow rates of 0.5 and 1.0 bed volumes per hour were recommended for further study. The tests showed that technetium was not adsorbed by CS-100, that cesium is adsorbed about 250 times more readily than ruthenium, and that radiation did not adversely affect resin cesium adsorption performance at exposures up to $1 \times 10^{9} \mathrm{Rad}$. 


\section{Johnson, 1991a, Westinghouse Hanford}

Engineering calculations (Johnson, 1991a), showed that the number of column volumes of NCAW that can be processed through the cesium ion exchange system as designed for B-Plant, was between 24 and 46 bed volumes, for a breakthrough $\mathrm{C} / \mathrm{C}_{0}$ of 0.01 (DF of 100). The calculations are based on data obtained with CS-100 and West Valley supernate simulants (Bray 1984). The information can be applied to other waste types and other column designs than that of B Plant.

\section{Johnson, 1991b, Westinghouse Hanford}

Using the modified Ergun equation and data developed for NCAW solutions, and CS-100 resin, bed pressure drops are calculated (Johnson, 1991b). The estimated pressure drop for NCAW supernate diluted $1: 1$ with water flowing at $30 \mathrm{gpm}$ through a $3 \mathrm{ft}$ diameter bed of $\mathrm{CS}-100$ resin of 30 mesh average particle size is about $0.39 \mathrm{psi} / \mathrm{ft}$. The information can be applied to other waste types and other column designs than that of B Plant.

\section{Bibler, 1991, Savannah River Laboratory}

Cesium distribution coefficients were determined for CS-100 and R-F resins in Savannah River, and NCAW supernate simulants before and after exposure to up to $10^{9}$ rad (Bibler, 1991). Results show that cesium distribution coefficients for the $R-F$ resin were 20 to 50 times higher than those of CS-100. Increasing the concentration of $\mathrm{CS}^{+}$in the NCAW simulant by a factor of 10 decreased the cesium distribution coefficients for the $R-F$ resin by a factor of 10, and for CS-100 resin by a factor of 5 . Neither resin showed a permanent loss of capacity on irradiation until a dose of greater than $10^{7}$ rad had been sustained. After a dose of $10^{9}$ rad, the R-F resin had lost 3 percent of it's original mass, and 80 percent of it's original capacity for cesium. The CS-100 resin, after receiving the same dose, had lost 4 percent of it's original mass and 55 percent of it's original capacity for cesium. Despite the loss of functionality due to radiolysis at $10^{9}$ rad, the cesium distribution coefficients for the R-F resin was still about 15 times higher than that of the CS-100 resin.

\section{Bray et a1., 1992, Pacific Northwest Laboratory}

Five hundred batch distribution values were obtained using three ion exchange materials; Ionsiv IE-96, CS-100, and R-F resin, and two Hanford waste simulants; NCAW, and complex concentrate (CC) (Bray et. a1. 1992). The following conclusions were developed:

- Cesium exchange capacity of the IE-96 and CS-100 exchangers double when temperature is decreased from $40^{\circ} \mathrm{C}$ to $10^{\circ} \mathrm{C}$. Cesium exchange capacity of the $R-F$ resin also increases with decreasing temperature but the effect is not as pronounced as with the other two exchangers. 
- The initial volume of feed that can be processed using IE-96 increases $\sim 50 \%$ with a $3 X$ feed dilution (6M Na ${ }^{+}$diluted to $2 \mathrm{M} \mathrm{Na}^{+}$). The initial volume of feed that can be processed using $R-F$ resin decreases $-10 \%$ with a $3 X$ feed dilution. The initial volume of feed that can be processed using CS -100 resin decreases $>30 \%$ with a $3 X$ feed dilution.

- The batch cesium distribution coefficients $\left(\mathrm{CS}^{+} \lambda\right)$ in NCAW and CC waste simulants at $5 \mathrm{M} \mathrm{Na}{ }^{+}$, and a $\mathrm{Na}^{+} / \mathrm{Cs}^{+}$mole ratio of $10^{4}$, and $10^{\circ} \mathrm{C}$ were developed as follows:

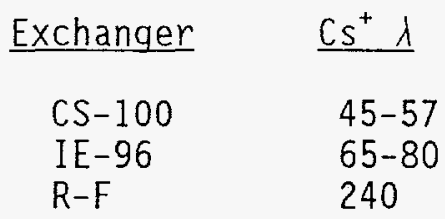

From these results, it is postulated that basic ion exchange data can be applied to a broad range of tank waste types.

- Potassium $\left(\mathrm{K}^{+}\right)$was found to exert an effect on cesium $\lambda$, over a $\mathrm{Na}^{+} / \mathrm{K}^{+}$range of 11 to 200 . An increasing amount of $\mathrm{K}$ was found to decrease the cesium $\lambda$ as the $K^{+}$competes with cesium for ion exchange sites.

- Rubidium $\left(R b^{+}\right)$was found to have a negligible effect on $\lambda$ over a $\mathrm{Na}^{+} / \mathrm{Rb}^{+}$range of $1.15 \times 10^{4}$ to $4.6 \times 10^{4}\left(\mathrm{Cs}^{+} / \mathrm{Rb}^{+}=0.2\right.$ to 92). While rubidium can be expected to compete with cesium, the $\mathrm{Cs}^{+} / \mathrm{Rb}^{+}$ ratios tested were not small enough to be significant.

Kurath et a1., 1994, Pacific Northwest Laboratory

Column and batch contact data was developed for CS-100 and R-F resins using NCAW, Double-Shell Slurry Feed (DSSF), and CC waste simulants (Kurath et. al. 1994).

The $R-F$ resin was much more selective for cesium than CS-100, roughly 6 -fold to 12 -fold at $25^{\circ} \mathrm{C}$ and up to 20 -fold at $40^{\circ} \mathrm{C}$ under some conditions. Potassium significantly reduced the cesium distribution coefficients of both resins.

The rate limiting step in loading $200 \mathrm{~mL}$ bench-scale columns of CS-100 and $R-F$ resin with NCAW simulant is diffusion in the particle phase based on tests completed to date. The breakthrough curves showed little to no dependence on the velocity of the fluid the resin bed, and mass transfer coefficients were nearly independent of the flow rate. The shape of the breakthrough curves were largely a function of the column residence time. 
In loading the bench-scale columns with DSSF simulant, the rate limiting step is diffusion in the particle phase with an element of film diffusion based on tests completed to date. The slope of the breakthrough curves was less dependent on the feed velocity than would be expected if loading were completely controlled by film diffusion. The apparent difference in the significance of film diffusion may be because DSSF is more viscous than NCAW; diffusion in viscous liquids is slower.

Solutions of both nitric acid and formic acid were used successfully to elute both resins. In some cases significant channeling was noted during acid elution of the $R-F$ resin resulting in a poor elution curve. In those specific cases the $R-F$ resin appeared to shrink, agglomerate, and pull away from the column walls causing the channeling. It is not known if the agglomerating/channeling problem will occur in a full scale column where the resin bed could settle under it's own weight alleviating the problem.

Comparison of equilibrium data for CC waste (high-organic complexant) to NCAW (low-organic) suggests that the complexants have little effect on the equilibrium behavior of the resins. The organic complexants are probably present as anions and do not participate in the exchange reaction. It is possible that repeated exposure to the organic complexants could foul the resins.

Processing of wastes at sodium concentration $>7 \mathrm{M} \mathrm{Na}^{+}$will be difficult at $25^{\circ} \mathrm{C}$. The DSSF simulant used was near it's solubi Tity 1 imit at $7 \mathrm{M} \mathrm{Na}^{+}$. Higher concentrations could risk solids precipitation and resin fouling. $R-F$ resin floated in the DSSF solution at $8 \mathrm{M} \mathrm{Na}^{+}$.

The tests showed that lower temperature favors cesium loading, but wi11 reduce loading rate. Higher process temperatures would increase diffusion rate, and waste component solubility, but would decrease resin capacity. Concentrated feed favor cesium loading, but reduced the loading rate in DSSF column runs. Detailed trade off studies were recommended to define the optimum processing conditions.

Brooks, Kim, and Kurath, 1994, Pacific Northwest Laboratory

In a study to identify candidate ion exchangers to remove cesium from Hanford tank waste, representatives from ten different major ion exchanger manufacturers were consulted, and 1iterature from the DOE complex was reviewed (Brooks, Kim, and Kurath, 1994). Twelve different ion exchangers were identified (see Table B-3) and these were compared on the following bases;

- cesium distribution coefficient

- rate of cesium sorption

- elution characteristics

- chemical, and radiochemical stability 


\begin{tabular}{|c|c|c|}
\hline Organic Resins & Organic Resins & Inorganic Materials \\
\hline Duolite ${ }^{T M}$ CS-100 & Amber 7 ite $^{\text {TM }}$ IRC -718 & Durasi $1{ }^{\circledR} 210$ \\
\hline Resorcinol Formaldehyde & Amberl ite $\mathrm{T}^{\mathrm{TM}}$ IRC-50 & Durasi ${ }^{\circledR 2} 230$ \\
\hline Duolite $\mathrm{e}^{\mathrm{TM}} \mathrm{C}-3$ & Amberlite ${ }^{\mathrm{TM}}$ DP-1 & Ionsiv ${ }^{T M}$ IE-95 \\
\hline Lewatit TM TP-207 & ResinTech ${ }^{\text {mM }}$ SIR-300 & Ions iv ${ }^{T M}$ IE-96 \\
\hline
\end{tabular}

Each exchanger was compared to the base 1 ine CS-100 resin. Resins with cesium distribution coefficients significantly lower than that of CS-100 were eliminated from consideration.

The study concluded that very few exchangers show strong cesium selectivity in highly alkaline solutions. Of the eight organic resins studied, only $R-F$, and Duolite $C-3$ have distribution coefficients as high or higher than CS-100. A11 of the inorganic exchangers were found to have cesium distribution coefficients of similar magnitude of that of CS-100. A summary of how these exchangers compared in terms of the selection criteria is shown in Table B-4.

\begin{tabular}{|l|c|c|c|c|}
\hline \multicolumn{4}{|c|}{ Table B-4. Summary of Exchanger Performance Relative to CS-100 } \\
\hline Property & CS-100 & R-F & C-3 & Inorganics \\
\hline $\begin{array}{l}\text { Cesium } \\
\text { Distribution } \\
\text { Coefficient }\end{array}$ & average & very high & average & average \\
\hline $\begin{array}{l}\text { Mass Transfer } \\
\text { Rate }\end{array}$ & high & high & -- & average \\
\hline Elutability & high & average & low & very low \\
\hline $\begin{array}{l}\text { Chemical } \\
\text { Stability }\end{array}$ & average & below average & -- & low \\
\hline $\begin{array}{l}\text { Radiation } \\
\text { Stability }\end{array}$ & average & below average & average & very high \\
\hline
\end{tabular}

The R-F resin performs significantly better than the CS-100 in cesium loading, and the $\mathrm{C}-3$ resin has loading characteristics similar to that of CS-100, however the elutability, chemical and radiochemical stability of these two resins may be a concern.

The inorganic exchangers have poor chemical stability in both high caustic and acidic solutions. The loaded inorganics would likely have to be vitrified as high level waste which would increase volume of HLW glass. 


\section{REFERENCES}

Baumgarten, P. K., R, M, Wallace, D. A. Whitehurst, and J. M. Steed, 1979, Development of an Ion Exchange Process for Removing Cesium from High-Level Radioactive Liquid Waste, November 1979, E. I. du Pont de Nemours \& Co., Savannah River Laboratory, Aiken, South Carolina.

Baumgarten, P. K., M, A, Ebra, L. L. Kilpatrick, and L. M. Lee, 1981, Ion Exchange Processes for Decontaminating Alkaline Radioactive Waste, February 1981, E. I. du Pont de Nemours \& Co., Savannah River Laboratory, Aiken, South Carolina.

Bibler, J.P., 1991, A Comparison of Duolite CS-100 and SRS Resorcinol/Formaldehyde Ion Exchange Resins with Three High-Level Waste Simulants Before and After $V$-Irradiation, December 11, 1991, Westinghouse Savannah River Company, Savannah River Laboratory, Aiken, South Carolina.

Bray, L. A., et. a1., 1983, Loading/Elution Tests with Ion Exchangers Using Simulated West Valley Alkaline Supernatant, Pacific Northwest Laboratory, Richland, Washington.

Bray, L. A., et a]., 1992, Equilibrium Data for Cesium Ion Exchange of Hanford CC and NCAW Tank Waste, TWRSPP-92-005, April 30 1992, Pacific Northwest Laboratory, Richland, Washington.

Brooks, K. P., Kim, A. Y., and D. E. Kurath, 1994, Assessment of Commercially Available Ion Exchange Materials for Cesium Removal from Highly Alkaline Wastes, TWRSPP-94-095, Prepared for U.S. Department of Energy, by Pacific Northwest Laboratory, Richland, Washington.

Buckingham, J. S., $1991 \mathrm{a}$, Results From Batch Tests of Savannah River Laboratory and Duolite CS-100 Ion Exchange Resins, Internal Memo number 28110-PCL91-011, February 4, 1991, Westinghouse Hanford Company, Richland, Washington.

Buckingham, J. S., 1991b, Results of Batch Contacts of CS-100 With Synthetic NCAW, Internal Memo number 28110-PCL91-021, March 8, 1991, Westinghouse Hanford Company, Richland, Washington.

Chilton, J. M., 1981, The Use of a Phenolic-Carboxylic Acid Cation Resin in the Treatment of Low-Level Liquid Waste at the Oak Ridge National Laboratory, September 1981, Union Carbide Corporation, Oak Ridge National Laboratory, Oak Ridge, Tennessee.

Deere, D. C., 1990, Exposure Estimates for IX Resins in B-Plant, Internal Memo, June 11, 1990, Westinghouse Hanford Company, Richland, Washington.

Ebra, M. A., R. M. Wallace, D. D. Walker, and R. A. Wille, 1981, Tailored Ion Exchange Resins for Combined Cesium and Strontium Removal from Soluble SRP High-Level Waste, DP-MS-81-48, E. I. du Pont de Nemours \& Co., Savannah River Laboratory, Aiken, South Carolina. 
Fåuske and Associates, Inc., 1989, CS-100/HNO Reaction Tests, FAI/89-96, November 1989, Prepared for Westinghouse Hanford Company, Richland, Washington.

Ga17agher, S. A., 1986, Report of Current NCAW Ion Exchange Laboratory Data, Interna7 Letter 65453-86-088, June 20, 1986, Rockwe11 Hanford Operations, Richland, Washington.

Gallagher, S. A., 1987, Cesium Ion Exchange Column Tests Using Pre-1982 and Post-1982 Duolite CS 100 Resin Tests, SD-RE-TD-001, Rev. 0, June 22, 1987, Rockwel1 Hanford Operations, Richland, Washington.

Gale, L. A., 1986, Cesium Ion Exchange - CS-100 Resin Capacity, Meeting Minutes, June 17, 1986, Rockwell Hanford Operations, Richland, Washington.

Gale, L. A., 1987a, NCAW Ion Exchange Nitric Acid/Duolite CS 100 Resin Tests, Internal Letter 65453-87-040, March 23, 1987, Rockwel1 Hanford Operations, Richland, Washington.

Gale, L. A., 1987b, Preliminary Design of the Cell 18 Cesium/Nitric Acid Ion Exchange System, WHC-SD-WM-TI-311, Rev. 0, July 31, 1987, Westinghouse Hanford Company, Richland, Washington.

Gibson, M. W., and B. C. Landeene, 1986, Process Flowsheet, Demonstration of Neutralized Current Acid Waste Pretreatment at $B$ Plant, PFD-B-033-00001, Rev. A-0, August 1986, Rockwel1 Hanford Operations, Richland, Washington.

Gibson, M. W., and B. C. Landeene, 1987, Process Flowsheet, Demonstration of Neutralized Current Acid Waste Pretreatment at B Plant, PFD-B-033-00001, Rev. A-1, September 1987, Westinghouse Hanford Company, Richland, Washington.

Hazards Research Corporation, 1986, HRC Proposal C-5169-WJC, December 24, 1986, Submitted to Rockwell Hanford Operations, Richland, Washington.

Johnson, M. E., 1991a, Calculating the Theoretical Column Volumes Processed Through Duolite CS-100 Resin Column at Various Cesium Breakthrough Points, Internal Memo number 85250-91-041, May 20, 1991, Westinghouse Hanford Company, Richland, Washington.

Johnson, M. E., 1991b, Pressure Drop for Neutralized Current Acid Waste (NCAW) Supernate Flow Through a Duolite CS-100 Resin Column, Internal Memo number 85250-91-045, May 28, 1991, Westinghouse Hanford Company, Richland, Washington.

Kurath, D. E., et a1., 1990, Correlation of Laboratory Testing and Actual Operations for the West Valley Supernatant Treatment System, PNL-SA--16871, Apri1 1990, Pacific Northwest Laboratory, Richland, Washington. 
Kurath, D. E., et a1., 1994, Experimenta7 Data and Ana7ysis to Support the Design of an Ion Exchange Process for the Treatment of Hanford Tank Waste Supernatant Liquids, TWRSPP-94-094, September 1994, Pacific Northwest Laboratory, Richland, Washington.

bandeene, B. C., 1989, Revised Ion Exchange (IX) Synthetic Feed Recipe for IX Development Tasks, Internal Memo number 13315-89-BCL-008, March 22, 1989, Westinghouse Hanford Company, Richland, Washington.

Prignano, A. L., 1989a, PreTiminary Batch Contact Tests on Backup Resins for Proposed B Plant Process, Internal Memo number 12712-PCL89-121, May 25, 1989, Westinghouse Hanford Company, Richland, Washington.

Prignano, A. L., 1989b, Results of Batch Contact Tests on Backup Resins for Removal of Cesium from Synthetic NCAW, Internal Memo number 12712-PCL89130, June 15, 1989, Westinghouse Hanford Company, Richland, Washington.

Prignano, A. L., 1989c, Interim Report - Aging and cycling test of Duolite CS-100 Resin, Internal Memo number 12712-PCL89-151, August 24, 1989, Westinghouse Hanford Company, Richland, Washington.

Prignano, A. L., 1989d, Results from Aging and Cycling Test of Duolite CS-100 Resin, Internal Memo number 12712-PCL90-014, November 1, 1989, Westinghouse Hanford Company, Richland, Washington.

Wallace, R. M., and R. B. Ferguson, 1980, Development of an Improved Ion Exchange Process for Removing Cesium and Strontium from High-Level Radioactive Liquid Waste, DP-MS-80-65, November 1980, E. I. du Pont de Nemours \& Co., Savannah River Laboratory, Aiken, South Carolina.

Weiss, R. L., 1985, Investigation of New Ion Exchangers for the Recovery of Cesium-137 at B-P7ant, SD-RE-TP-008, Rev. 0, May 10, 1985, Rockwe 17 Hanford Operations, Richland, Washington.

Wiley, J. R., and R, M, Wallace, 1975, Removal of Cesium from Savannah River Plant Waste Supernate, DP-1388, July 1975, E. I. du Pont de Nemours \& Co., Savannah River Laboratory, Aiken, South Carolina. 
WHC-SD-WM-TI-638 REV 0

This page intentionally left blank. 